NARCISO VIEIRA JUNIOR

\title{
PAPEL DA RAB2A, RAB5A, RAB17 E RAB18 NA FUNÇÃO EFETORA DE CÉLULAS CITOTÓXICAS
}

Tese apresentada ao Programa de Pós-Graduação em Imunologia do Instituto de Ciências Biomédicas da Universidade de São Paulo, para obtenção do Título de Doutor em Ciências. 
NARCISO VIEIRA JUNIOR

\section{PAPEL DA RAB2A, RAB5A, RAB17 E RAB18 NA FUNÇÃO EFETORA DE CÉLULAS CITOTÓXICAS}

Tese apresentada ao Programa de Pós-Graduação em Imunologia do Instituto de Ciências Biomédicas da Universidade de São Paulo, para obtenção do Título de Doutor em Ciências.

Área de concentração: Imunologia

Orientador: Prof. Dr. João Gustavo Pessini AmaranteMendes

Versão original 
CATALOGAÇÃO NA PUBLICAÇÃO (CIP)

Serviço de Biblioteca e informação Biomédica

do Instituto de Ciências Biomédicas da Universidade de São Paulo

Ficha Catalográfica elaborada pelo(a) autor(a)

Vieira, Narcisoo Junior

Papel da RAB2A, RAB5A, RAB17 e RAB1B na Funç⿰氵㔾。

Bfetora de Celulaa Citot6xicaa / Nareiao Junior

Vieira; orientador Jošo Guatavo Peanini Amarante-

Menden. -. Sto Paulo, 2016.

$141 \mathrm{P}$.

Teate (Doutorado)) -- Univeraidade de sao Paulo, Instituto de Ciencias Biomedicas.

1. RAB GTPane. 2. Celulaa Citot6xicas. 3. Trafego Intracelular. 4. RAB2A. 5. Celulae Natural Killer. I. Peasini Amarante-Mendea, Jolo Guatavo, orientador. II. Titulo. 
Candidato(a): Narciso Junior Vieira

Título da Tese: Papel da RAB2A, RAB5A, RAB17 e RAB18 na função efetora de células citotóxicas

Orientador(a): João Gustavo Pessini Amarante-Mendes

A Comissão Julgadora dos trabalhos de Defesa da Tese de Doutorado, em sessão pública realizada a considerou

( ) Aprovado(a)

( ) Reprovado(a)

Examinador(a): Assinatura:

Nome:

Instituição:

Examinador(a): Assinatura:

Nome:

Instituição:

Examinador(a): Assinatura:

Nome:

Instituição:

Examinador(a): Assinatura:

Nome:

Instituição:

Presidente: Assinatura:

Nome:

Instituição: 


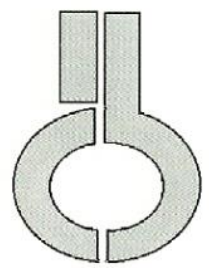

UNIVERSIDADE DE SÃO PAULO

INSTITUTO DE CIÊNCIAS BIOMÉDICAS

Cidade Universitária "Armando de Salles Oliveira"

Av. Prof. Lineu Prestes, 2415 - cep. 05508-000 São Paulo, SP - Brasil

Telefone :(55) (011) 3091.7733 e-mail: cep@icb.usp.br

Of.CEUA. 080.14

São Paulo, 14 de outubro de 2014.

REF,: Protocolo $n^{0}$ 158/11.

"Papel da Rab2a,Rab51, Rab17 e Rab18 na função efetora de células citotóxicas"

Prezado Professor,

Informo que a sua licença para uso de animais em experimentação, constante no protocolo em epígrafe, foi prorrogada até 20.10.2017.

Reitero que havendo alteração de metodologia e inserção de novos alunos ao projeto de pesquisa vinculado à referida licença a CEUA/ICB deverá ser informada.

Cordialmente,

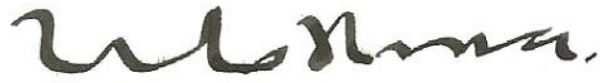

Prof. Dr. WOTHAN TAVARES DE LIMA

Coordenador - CEUA-ICB/ /USP

$\operatorname{Ilmo}^{(\mathrm{a}) \cdot} \mathrm{Sr}^{\text {(a). }}$

Prof $^{\left({ }^{(a)}\right.}$. Dr ${ }^{(a)}$ João Gustavo Pessini Amarante-Mendes

Departamento de Imunologia

Instituto de Ciências Biomédicas - USP 
DEDICADO EM MEMÓRIA DE UM GRANDE GUERREIRO, UM HERÓI ANÔNIMO, UM VERDADEIRO EDUCADOR, FAZENDEIRO APAIXONADO E PAI AMOROSO, QUE SE FOI E DEIXOU MUITA SAUDADE. 


\section{AGRADECIMENTOS}

Agradeço a Deus pela força diária, fundamental para o desenvolvimento deste trabalho; pela luz, necessária a cada tomada de decisão; e principalmente pela paciência, porque sem muito dela Ele não teria me dado toda a força e luz que me deu;

Agradeço a minha esposa Milene, que esteve ao meu lado em todos os momentos e que embora não tenha ido para bancada comigo (porque para o laboratório ela foi várias vezes), seu apoio incondicional foi muito importante para mim. Espero que ela tenha aprendido um pouco de imunologia após tantas conversas que tivemos;

Ao meu filho recém chegado Gabriel, que trouxe mais alegria para a minha vida;

Aos meus pais, que investiram desde cedo na minha educação e me ensinaram que tudo na vida se conquista com muito suor e muito trabalho. Além disso, me ensinaram valores como humildade, honestidade e ética, que são a base da pessoa que sou hoje;

Ao meu orientadorprofessor Dr. Gustavo, por compartilhar comigo a sua sabedoria e me ensinar a maior parte do que eu sei sobre Ciência;

Aos meus colegas, amigos e alguns até padrinhos de casamento do laboratório, por sua companhia, cumplicidade, ajuda, enfim, por dividirem comigo o pesado fardo do doutorado comigo e tornarem o peso dessa cruz mais leve;

Aos professores da USP e demais professores que conheci ao longo do doutorado, por suas brilhantes lições, conselhos, colaborações e o mais importante, por sua amizade;

Aos funcionários, técnicos, colaboradores e pessoas da iniciativa privada por sua grande ajuda nos bastidores desta tese;

Às agencias de fomento FAPESP e CNPq, que forneceram subsídios para que eu pudesse desenvolver este trabalho.

A todos, que direta ou indiretamente, participaram de alguma maneira desses meus quase seis anos na Universidade. 
"Tenho a impressão de ter sido uma criança brincando à beira-mar, divertindo-me em descobrir uma pedrinha mais lisa ou uma concha mais bonita que as outras, enquanto o imenso oceano da verdade continua misterioso diante de meus olhos". (Isaac Newton) 


\section{RESUMO}

VIEIRA JUNIOR, N. Papel da RAB2A, RAB5A, RAB17 e RAB18 na função efetora de células citotóxicas.140 P. Tese (Doutorado Em Imunologia) - Instituto de Ciências Biomédicas, Universidade De São Paulo, São Paulo, 2016.

Linfócitos T CD8 e células NK atuam no combate à infecções por bactérias intracelulares, vírus e células tumorais, provocando a morte dessas células por meio da secreção de grânulos citotóxicos. Proteínas RAB GTPase têm se destacado em estudos de tráfego intracelular, porém, são escassos dados sobre o papel destas proteínas em células citóxicas. Um estudo prospectivo de proteômica realizado por nosso grupo identificou a RAB2A, RAB5A, RAB17 e RAB18 em grânulos citotóxicos. Análises mais aprofundadas revelaram que a RAB2A está associada a proteínas como LAMP-1 e LAMP-2, enquanto que RAB5A, RAB17 e RAB18 estavam presentes na mesma linhagem em um contexto não contemplado neste estudo. Desenvolvemos ainda uma abordagem de silenciamento gênico da RAB2A, e por fim, adaptamos uma série de protocolos de simples execução e baixo custo para avaliar funções efetoras de células NK. O conhecimento da maquinaria secretória é fundamental, uma vez que defeitos nas vias de tráfego intracelular constituem a base de um grande número de doenças que desencadeiam quadros fatais.

Palavras-chave: Tráfego intracelular. Células citotóxicas.Células natural killer.RAB GTPase. RAB2A. 


\begin{abstract}
VIEIRA JUNIOR, N. Role of RAB2A, RAB5A, RAB17 andRAB18 in effector functions of cytotoxic cells.140 P. Ph.D.Thesis (immunology) - Instituto De Ciências Biomédicas, Universidade De São Paulo, São Paulo, 2016.

CD8 T lymphocytes and NK cells fight against infections by intracellular bacteria, viruses and tumor cells by killing those cells through the secretion of cytotoxic granules. RAB GTPase has been highlighted in studies of intracellular trafficking, however there are scarce reports regarding the role of these proteins in cytotoxic cells. A proteomic study performed by our group identified RAB2A, RAB5A, RAB17 and RAB18 in cytotoxic granules. Further analysis revealed that RAB2A is associated with LAMP-1 and LAMP-2, while RAB5A, RAB17 and RAB18 were present in the same cell line, but in a context not included in this study. We also have developed a gene silencing approach for RAB2A and adapted a number of protocols, simple and low-cost, that can be used to evaluate effector functions of natural killer cells The knowledge of secretory machinery involved in the movement cytotoxic granules of cytotoxic cells is critical, since defects in intracellular trafficking pathways constitute the basis for a large number of diseases which trigger death.
\end{abstract}

Keywords:intracellular trafficking. Cytotoxic cells. Natural killer cells. RAB GTPase. RAB2A. 


\section{LISTA DE ILUSTRAÇÕES}

Figura 1 -- Representação esquemática do desenvolvimento e diferenciação de células NK

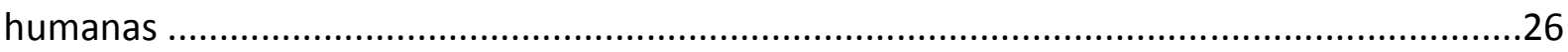

Figura 2 - Estratégias de reconhecimento das células NK.............................................27

Figura 3 - Receptores das células NK humanas e murinas...................................................22

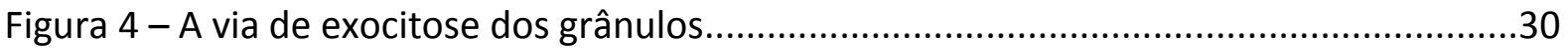

Figura 5 - Polarização dos grânulos citotóxicos em direção a sinapse imunológica de uma

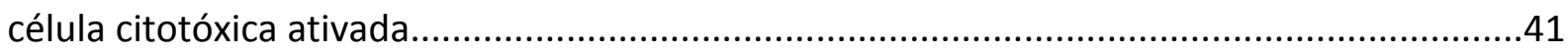

Figura 6 -Localização celular e função das RABs GTPases.....................................................45

Figura 7 - Figura esquemática da estrutura tridimensional do H-Ras complexado a um

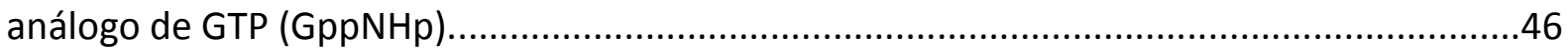

Figura 8 - Circuito de ativação e desativação das RAB GTPases..............................................48

Figura 9 - Imagem representativa do plasmídeo pLKO.1...............................................62

Figura 10 - Imagem representativa do plasmídeo lentiCRISPRv2 ...................................69

Figura 11 - Marcação com SDS-PAGE seguida de "Coomassie Blue" revelou as bandas mais proeminentes em níveis similares em duas amostras representativas................................77

Figura 12 - Padronização do anticorpo RAB2A nas proporções 1:50, 1:100 e 1:150 para identificação dessa proteína em células YT observada por microscopia confocal de fluorescência.

Figura 13 - Padronização do anticorpo RAB5A na proporção 1:50 para identificação dessa proteína em células YT observada por microscopia confocal de fluorescência. 80

Figura 14- Padronização do anticorpo RAB17 nas proporções 1:50, 1:100 e 1:150 identificação dessa proteína em células YT observada por microscopia confocal de fluorescência.

Figura 15- Padronização do anticorpo RAB18 na proporção 1:50 para identificação dessa proteína em células YT observada por microscopia confocal de fluorescência.

Figura 16 - Análises de microscopia confocal revelam a presença da RAB5A em uma linhagem celular humana de células NK.

Figura 17 - Células YT incubadas com anticorpos secundários conjugados com fluorocromos na ausência de anticorpo anti-RAB5A para avaliação de marcação inespecífica. 
Figura 18 - Análises de microscopia confocal revelam a presença da RAB17 em grânulos citotóxicos de uma linhagem celular humana de células NK.

Figura 19 - Células YT incubadas com anticorpos secundários conjugados com fluorocromos na ausência de anticorpo anti-RAB17 para avaliação de marcação inespecífica.

Figura 20 - Análises de microscopia confocal revelam a presença da RAB18 em grânulos citotóxicos de uma linhagem celular humana de células NK

Figura 21 - Células YT incubadas com anticorpos secundários conjugados com fluorocromos na ausência de anticorpo anti-RAB18 para avaliação de marcação inespecífica......

Figura 22- Colocalização de RAB2A e LAMP-1 em células YT observada por microscopia confocal de fluorescência.

Figura 23 - Colocalização de RAB2A e LAMP-2 em lisossomos de células YT observada por microscopia confocal de fluorescência.

Figura 24 - Colocalização de RAB2A e Perforina em lisossomos de células YT observada por microscopia confocal de fluorescência.

Figura 25 -Colocalização de RAB2A e Granzima B em lisossomos de células YT observada por microscopia confocal de fluorescência.

Figura 26 - Análises de microscopia confocal revelam a presença da RAB2A em grânulos citotóxicos de uma linhagem celular humana de células NK.

Figura 27 - Células YT incubadas com anticorpos secundários conjugados com fluorocromos na ausência de anticorpo anti-RAB2A para avaliação de marcação inespecífica.

28 - Análise quantitativa da colocalização de RAB2A e os marcadores de lisossomos

Figura 29 - Microscopia eletrônica de transmissão (MET) confirma a presença da RAB2A em lisossomos de células citotóxicas.

Figura 30-Caracterização fenotípica de blastos de linfócitos T CD8. .96

Figura 31 - Caracterização fenotípica dos blastos de linfócitos T CD8 submetidos ao protocolo de separação utilizando beads magnéticas.

Figura 32 Curva de titulação para determinação da dose ótima de Puromicina em células murinas primárias.

Figura 33 - Digestão do vetor lentiviral lentCRISPR v2

Figura 34 - Imagem ilustrativa do software para desenho de gRNA para RAB2A humana do site GenScript. 100

Figura 35 - Imagem ilustrativa do software para desenho de gRNA para RAB2A humana do site GenScript 101 
Figura 36 Imagem ilustrando análise do programa Matcher dos gRNA gerados utilizando ferramentas de bioinformática....

Figura 37 - Análise de sequênciamento de três clones de bactérias diferentes portando o gRNA-1 desenvolvido no programa DNA 2.0 (gRNA-1-1; gRNA-1-2; gRNA-1-3).

Figura 38- Análise de sequênciamento de três clones de bactérias diferentes portando o gRNA-2 desenvolvido no programa GenScript (gRNA-2-1; gRNA-2-2; gRNA-2-3). .104

Figura 39 - Células HEK293T transfectadas com plasmídeo contendo gene do receptor de interferon fluorescente com 24horas, 48horas e 72 horas após a transfecção. 106

Figura 40 - Curva de titulação para determinação da dose ótima de Puromicina em linhagem celular humana YT. 107

Figura 41 - Western blot de células YT transduzidas com CRISPR/CAS9 avaliando a expressão de LAMP-1, RAB2A, perforina e actina. .108

Figura 42 - Cinética para padronização do tempo de contato entre células efetoras YT e células alvo RAJI. 109

Figura 43 - Padronização do marcador de lisossomos LysoTracker ${ }^{\circledR}$ para análise da população de lisossomos 109

Figura 44 - Estratégia de gate utilizada na análise do experimento de ativação de células NK.

Figura 45 - Gráficos das médias das frequências de células positivas para os marcadores de ativação CD25, CD40L e CD69 em células NK submetidas ao ensaio de ativação e avaliadas por citometria defluxo.

Figura 46 - Análise por RT-PCR (qRT-PCR) da expressão do mRNA de Rab2A, Rab5A, Rab17 e Rab27A em linfócitos T CD8 ex-vivo ativados. 


\section{LISTA DE TABELAS}

Tabela 1 - Tabela contendo informações sobre os shRNA utilizados nos experimentos para o silenciamento gênico da RAB2A.

Tabela 2 - Tabela contendo informações sobre o ciclo realizado no termociclador para conversão do mRNA em cDNA.

Tabela 3 - Lista das proteínas mais abundantes identificadas nos preparados das amostras dos grânulos das CTLs em 1D-SDS-PAGE.

Tabela 4-Lista das proteínas identificadas por eletroforese 2D. 


\section{LISTA DE ABREVIATURAS E SIGLAS}

2-DE - Eletroforese em duas dimensões

ADCC - Citotoxicidade celular dependente de anticorpo

AICD - Morte celular induzida por ativação

AP3 - Proteína adaptadora-3

APC - Antigen presenting cell

CCR3 -Chemokine (C-X-C motif) receptor 3

CCR7 - Chemokine (C-C motif) receptor 7

CCR5 - Chemokine ( $\mathrm{C}-\mathrm{C}$ motif) receptor 5

CCR8 - Chemokine (C-C motif) receptor 9

CCR9 - Chemokine ( $\mathrm{C}-\mathrm{C}$ motif) receptor 9

CXCR7 - Chemokine (C-X-C motif) receptor 3

CD2 - Cluster of differentiation 2

CD4 - Cluster of differentiation 4

CD8 - Cluster of differentiation 8

CD11b - Cluster of differentiation 11b

CD16 - Cluster of differentiation 16

CD27 - Cluster of differentiation 27

CD28 - Cluster of differentiation 28

CD34 - Cluster of differentiation 34

CD40 - Cluster of differentiation 40

CD40L-CD40 ligand

CD45 - Cluster of differentiation 45

CD56 - Cluster of differentiation 56

CD62L -CD62 Ligand 
CD70 - Cluster of differentiation 70

CD80 - Cluster of differentiation 80

CD86 - Cluster of differentiation 86

CD94 - Cluster of differentiation 94

CD95 - Cluster of differentiation 95

CD107a-Cluster of differentiation 107a

CD107b - Cluster of differentiation 107b

CD122 - Cluster of differentiation 122

CD152 - Cluster of differentiation 152

CD178- Cluster of differentiation 178

CHS - Síndrome de Chediak-Higashi

CMV - Citomegalovírus

cSMAC - Domínio de ativação supramolecular central

CTL - Cytotoxic T lymphocytes

CTLA-4 - cytotoxic T-lymphocyte-associated protein 4

DAP10 - DNAX-activating protein 10

DNA - Ácido desoxirribonucleico

DNAM-1 - DNAX Accessory Molecule-1

DC - Dendritic cell

EOMES - Eomesodermina

Ets1 - V-ets avian erythroblastosis virus E26 oncogene homolog 1

H60 - Minor histocompatibility molecule 60

HPS - Síndrome de Hermansky-Pudlak

EBV - Epstein-Barr virus

ERK - Extracellular signal-regulated kinase

FASL - FAS ligand 
GAP - GTPase-activating protein

GDI - Guanine nucleotide dissociation inhibitor

GDP - Guanosine diphosphate

GEF - Guanine-nucleotide exchange factors

GS - Síndrome de Griscelli

GTP - Guanosine triphosphate

HIV - Vírus da imunodeficiência humana

IgA - Imunoglobulina A

IgG - Imunoglobulina G

IgM - Imunoglobulina M

IL-2 - Interleucina 2

IL-2R - Receptor da subunidade beta de IL-2

IL-7 - Interleucina 7

IL-12- Interleucina 12

IL-15 - Interleucina 15

IL-15R - Receptor de IL-15

IFN- $\gamma-$ Interferon-gama

ITAM - Immunoreceptor tyrosine-based activation motif

ITIM - Immunoreceptor tyrosine-based inhibition motifs

KIR - killer-cell inhibitory receptor

LAMP-1 - Lysosomal-associated membrane protein 1

LAMP-2 - Lysosomal-associated membrane protein 2

LAMP-3 - Lysosomal-associated membrane protein 3

LFA-1 - Lymphocyte function- associated antigen 1

LILR - Leukocyte Immunoglobulin-like Receptor

Ly49H - Lymphocyte antigen $49 \mathrm{H}$ 
MHC I - Complexo principal de histocompatibilidade do tipo I

MHC II - Complexo principal de histocompatibilidade do tipo II

MIP-1 $\beta$ - Macrophage inflammatory protein-1 beta

MIC - MHC class I chain-related

mRNA - Messenger ribonucleic acid

MTOC - Centro organizador de microtúbulos

MULT1 - Mouse UL-16 binding protein-like transcript 1

NK - Natural killer cell

PAMP - Pathogen-associated molecular pattern

PBMC - Peripheral blood mononuclear cell

pSMAC - Domínio de ativação supramolecular periférica

Pyk2 - Protein tyrosine kinase-2

RAB1 - Ras-related protein Rab-1

RAB2A - Ras-related protein Rab-2A

RAB5A - Ras-related protein Rab-5A

RAB7 - Ras-related protein Rab-7

RAB8 - Ras-related protein Rab-8

RAB11 - Ras-related protein Rab-11

RAB17 - Ras-related protein Rab-17

RAB18 - Ras-related protein Rab-18

RAB25 - Ras-related protein Rab-25

RAB27A - Ras-related protein Rab-27A

RAB38 - Ras-related protein Rab-38

RAE1 - Retinoic acid early transcript 1

REP - RAB escort protein

RIG-I - Retinoic acid-inducible gene-I 
RUNX1 - Runt-related transcription factor 1

Runx3 - Runt-related transcription factor 3

SNARE - Soluble N-ethyl maleimide sensitive factor (NSF) attachment protein receptor

STAT5 - Signal Transducer and Activator of Transcription $5 r$

TCR - Receptor de células T

Tcm- Células T de memória central

Tem - Células T de memória efetoras

TGN - Trans-Golgi-Network

Th1 - T helper cells type 1

Th2 - T helper cells type 2

Thpok - Th inducing POZ-Kruppel Factor

TCR - T cell receptor

TLR - Toll-like receptors

TNF- $\alpha$ - Tumor necrosis factor alpha

TRAIL - Tumor necrosis factor-related apoptosis-inducing ligand

ULBP - UL16-binding protein 


\section{SUMÁRIO}

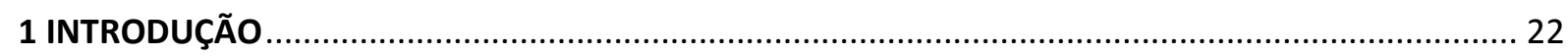

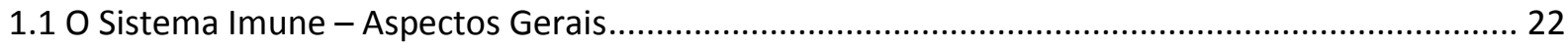

1.2 Células Natural Killer: Uma primeira linha de defesa do organismo contra vírus, bactérias

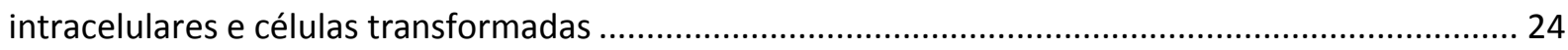

1.3 Linfócitos T CD8: Potentes Matadores Da Imunidade Adaptativa .................................................. 32

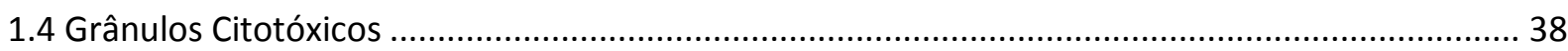

1.5 RAB GTPases: Organizando O Tráfego Intracelular Desde Os Primórdios Da Vida .......................... 42

1.6 Doenças Associadas A Defeitos Nas Vias De Tráfego Intracelular .................................................. 50

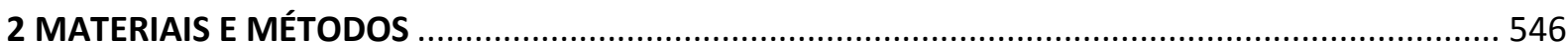

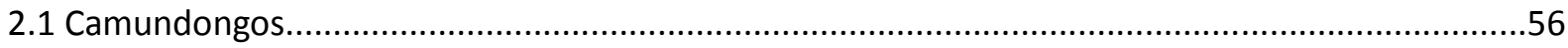

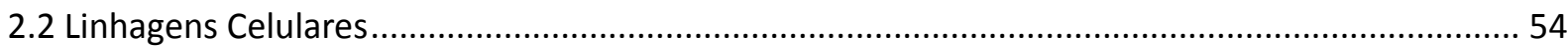

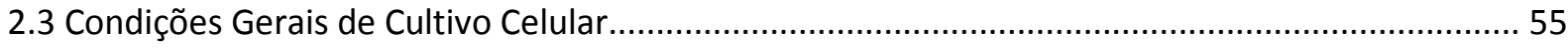

2.4 Protocolo de imunofluorescência para microscopia confocal ....................................................... 55

2.5 Protocolo de imunohistoquímica para microscopia eletrônica de transmissão............................... 56

2.6 Geração de blastos de linfócitos T CD8

2.7 Protocolo de separação celular por beads magnéticas .................................................................. 59

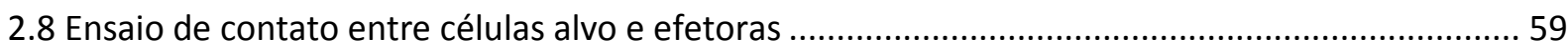

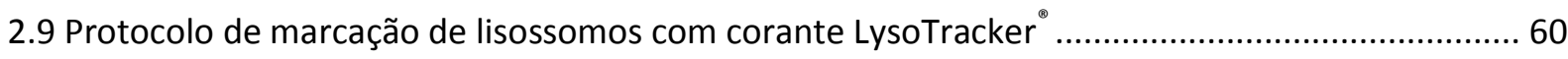

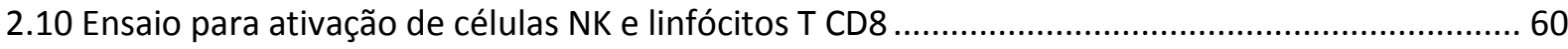

2.11 Protocolo de transdução estável de células primárias não aderentes utilizando lentivírus

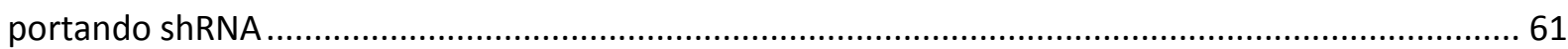

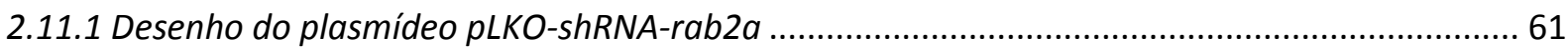

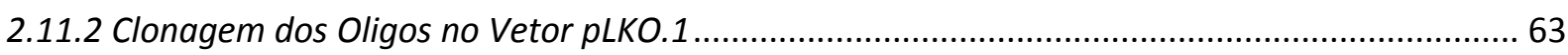

2.11.3 Transformação Bacteriana com plasmídeo pLKO-shRNA-rab2a............................................. 64

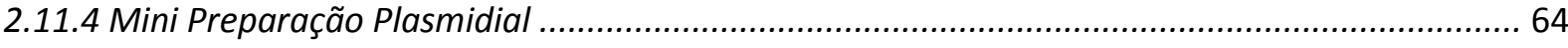

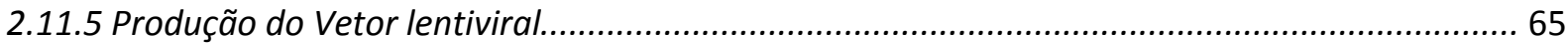

2.11.6 Protocolo De Infecção Lentiviral De Células Primárias Em Suspenção....................................... 65

2.11.7 Ensaio para determinação da concentração ótima de Puromicina ............................................ 66

2.12 Protocolo de imunofluorescência para citometria de fluxo ....................................................... 66 
2.13 Protocolo de extração de mRNA e PCR Real Time.

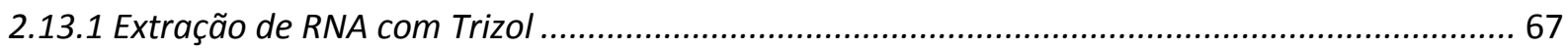

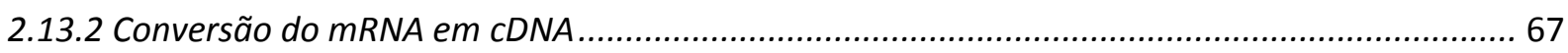

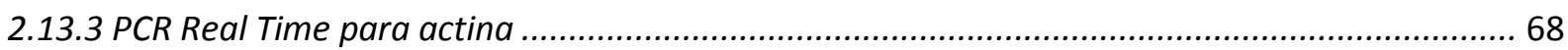

2.14 Protocolo De Edição Genômica Utilizando A Ferramenta De Biologia Molecular CRISPR/CAS-9. 69

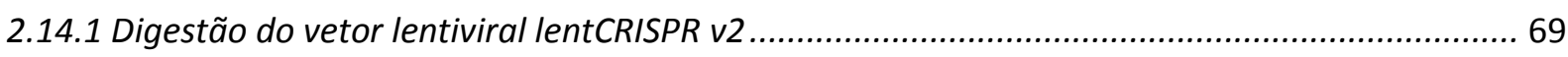

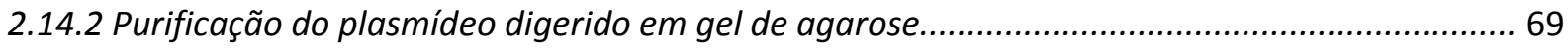

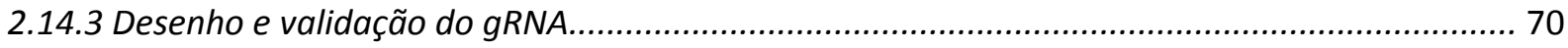

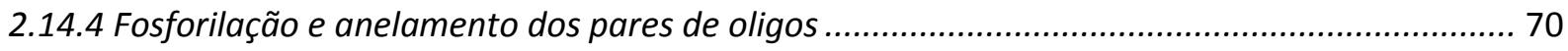

2.14.5 Reação de ligação dos oligos anelados ao plasmídeo digerido ................................................ 71

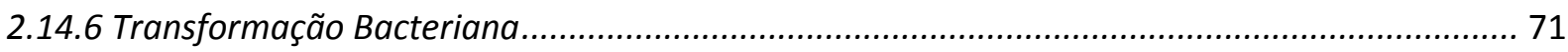

2.14.7 PCR de colônia para avaliação da transformação das bactérias stb/3 .................................... 72

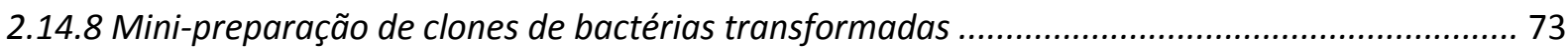

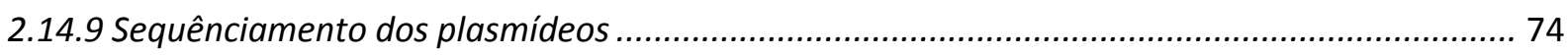

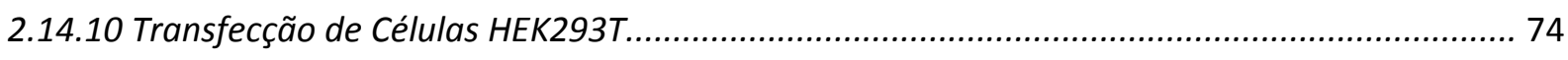

2.14.11 Transdução de células YT utilizando partículas lentivirais ..................................................... 75

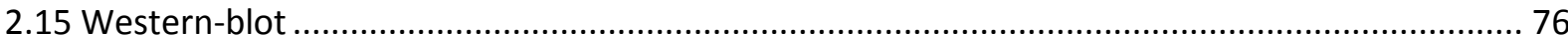

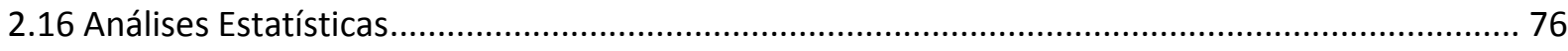

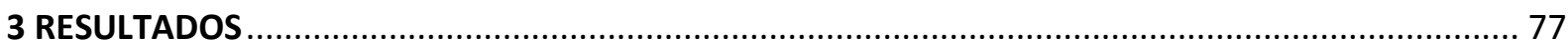

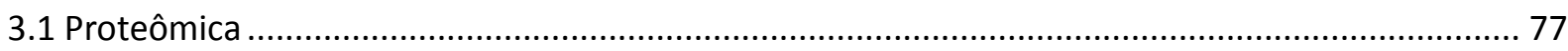

3.2 Validação dos Resultados Preliminares por Microscopia Confocal ............................................... 78

3.3 Padronizações dos anticorpos utilizados nos ensaios de microscopia confocal.............................. 79

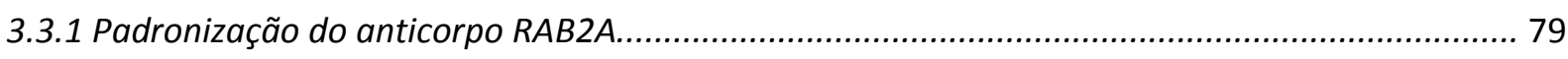

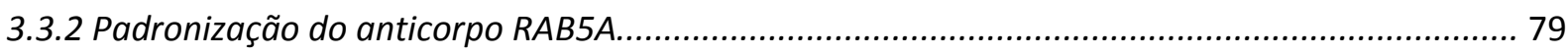

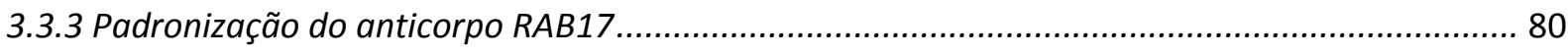

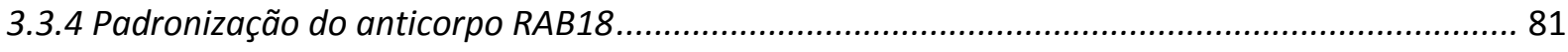

3.4 Ensaios de microscopia confocal para detecção de RAB5A e marcadores de lisossomos .............. 83

3.5 Ensaios de microscopia confocal para detecção de RAB17 e marcadores de lisossomos ............... 85

3.6 Ensaios de microscopia confocal para detecção de RAB18 e marcadores de lisossomos............... 86

3.7 Ensaios de microscopia confocal para detecção de RAB2A e marcadores de lisossomos ............. 88

3.8 Análise para quantificação da colocalização de RAB2A e LAMP-1, LAMP-2, Perforina e Granzima B

3.9 Microscopia Eletrônica de Transmissão de Células Natural Killer da Linhagem Humana YT com marcação da proteína RAB2A em grânulos citotóxicos 
3.10 Protocolo de transdução estável de células não aderentes utilizando lentivírus portando shRNA 95

3.11 Protocolo De Edição Genômica Utilizando CRISPR/CAS-9 …......................................................... 98

3.11.1 Digestão do plasmídeo LentCrispr v2 com enzima BsmBI..................................................... 98

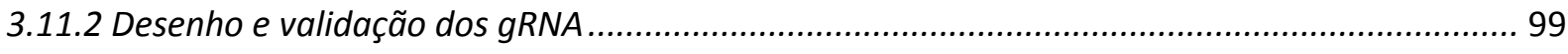

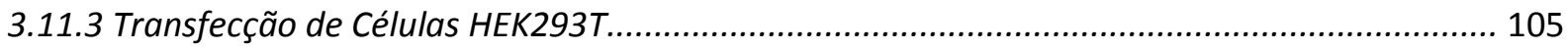

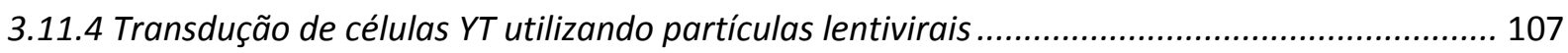

3.12 Ensaios para avaliação das funções efetoras de células NK ....................................................... 108

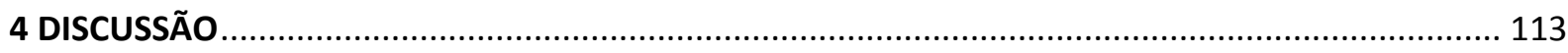

5 CONCLUSÃO

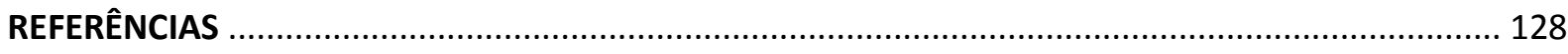

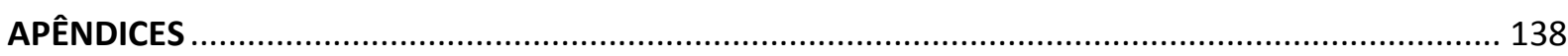

APÊNDICE A - Tabela 3 - Lista das proteínas mais abundantes identificadas nos preparados das

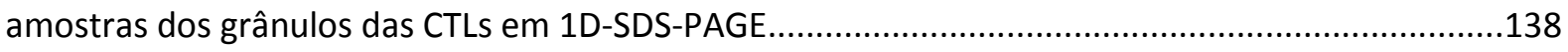

APÊNDICE B - Lista das proteínas identificadas por eletroforese 2D..............................................139 


\section{INTRODUÇÃO}

\subsection{O Sistema Imune - Aspectos Gerais}

O sistema imune é constituído por moléculas, células, tecidos e órgãos que formam uma rede dinâmica cujo objetivo é manter a homeostasia do organismo. Este sistema tem sido didaticamente dividido em imunidade inata ou natural e imunidade adaptativa ou adquirida.

As respostas da imunidade inata são em geral rápidas e estereotipadas contra um grande, porém, limitado número de estímulos, não sofrendo alterações em termos de quantidade ou qualidade após o estímulo. São constituídas por barreiras físicas, químicas e biológicas, células especializadas e moléculas solúveis, presentes em indivíduos saudáveis e que formam uma linha de defesa inicial contra microrganismos, macromoléculas como proteínas e polissacarídeos, e outras substâncias reconhecidas como "não-próprias".

Mecanismos da imunidade inata podem ser encontrados em representantes de quase todas as formas de vida conhecidas no planeta. Embora diferentes componentes desse tipo de imunidade sejam empregados para eliminar agentes agressores, uma característica comum a todos elesé uso de receptores para o reconhecimento de padrões de patógenos (PAMPs), ou componentes próprios alterados, como os receptores do tipo Toll (TLRs), RNA helicases como RIG-I (do inglês, retinoic acid-inducible gene-I), receptores lectina do tipo C, dentre outros codificados pela linhagem germinativa (1).

Entre as células que fazem parte da imunidade inata podemos citar os macrófagos, células dendríticas (DCs), mastócitos, neutrófilos, eosinófilos e as células natural killer (NK). Estas células podem ser ativadas durante um processo inflamatório e rapidamente adquirir características com o propósito de, por exemplo, eliminar um microrganismo invasor. Muitas vezes essas células são capazes de conter sozinhas o agente invasor, entretanto, quando os mecanismos da imunidade inata são insuficientes para resolução do quadro, recorre-se aos mecanismos da imunidade adaptativa (2).

Um grande destaque deve ser dado às DCs, fundamentaispara estabelecer uma conexão entre as respostas inatas e adaptativas, uma vez que elas podem reconhecer, capturar, processar e apresentar antígenos aos linfócitos. Além disso, elas podem expressar moléculas coestimulatórias em sua superfície e possuem uma capacidade extraordinária de 
migrar para órgãos linfóides e secretar citocinas importantes para o estabelecimento das respostas adaptativas (3). Um exemplo prático da importância destas células é sua capacidade de estimular respostas humorais com a produção de imunoglobulinas como IgM, IgG, IgA e respostas celulares Th1 e Th17, bem como respostas de linfócitos T CD8 (4). Assim, as DCs, por conta dessas características são também chamadas de células apresentadoras de antígeno profissionais (APCs).

Nos vertebrados mandibulados e em não mandibulados como a lampréia, patógenos e outros fatores exercerampressões seletivas que favoreceram o surgimento de inovações morfológicas e funcionais, tornando os organismos mais adaptados a diferentes situações. Dentre essas inovações, podemos destacar a evolução dos receptores do sistema imune adaptativo há aproximadamente 500 milhões de anos, bem como o desenvolvimentode suas propriedades. Os mecanismos centrais por trás desse novo sistema atualmente são bem entendidos e nos mamíferos caracterizam-se por seleção clonal, diferenciação compartimental de linfócitos, hipermutação somática, exclusão alélica e memória imunológica (5).

Os principais componentes celulares da imunidade adaptativa são os linfócitos. Estes se originam a partir de células tronco hematopoiéticas na medula óssea e diferenciam-se em duas subpopulações, os linfócitos B e os Linfócitos T. Essa distinção ocorre devido à influência de genes que regulam o desenvolvimento dessas células, aos sítios anatômicos que o desenvolvimento ocorre e a diferenças funcionais entre os receptores de antígenos (6).

Desde os tubarões até os mamíferos, os vertebrados mandibulados desenvolveram um sistema imune adaptativo fundamentado em um repertório de receptores altamente diversos, representado por anticorpos e receptores de células T (TCR). Esses receptores são compostos por domínios imunoglobulina e gerados por rearranjos de diferentes segmentos gênicos presentes nas regiões variáveis (V), de diversidade (D) e de junção (J). Como consequência desse processo, estima-se que o repertório dos linfócitos de um indivíduo adulto saudável seja capaz de discriminar entre $10^{7}$ e $10^{9}$ diferentes determinantes antigênicos (7), conferindo uma grande vantagem em termos de defesa contra uma ampla 
gama de agentes agressores, bem como seus possíveis mecanismos de evasão do sistema imune.

Entre os linfócitos $T$, dois subtipos principais se destacam na periferia expressando as moléculas co-receptoras CD4 ou CD8. Linfócitos T helperou auxiliadores (T CD4) são células que expressam a molécula CD4 em sua superfície e cujo TCR restringe-se ao reconhecimento de antígenos presentes em moléculas do complexo principal de histocompatibilidade do tipo II (MHC II). Já os linfócitos T citotóxicos ou citolíticos (T CD8) são células que expressam o coreceptor CD8 em sua superfície, cujo TCR reconhece antígenos presentes em moléculas do complexo principal de histocompatibilidade do tipo I (MHC I). Tanto os linfócitos T CD4 quanto T CD8 desenvolvem-se no timo e a geração dessas células é provavelmente um dos sistemas mais bem caracterizados em mamíferos. O comprometimento com algum desses compartimentos envolve a participação de genes reguladores, a participação de diferentes fatores de transcrição e estudos mais recentes apontam para um papel importante da sinalização do TCR durante o processo de seleção positiva no timo $(8,9)$.

Embora nesta primeira parte do trabalho tenham sido apresentados aspectos gerais das respostas imunes, a discussão se pautará nos próximos itens em torno das células citotóxicas, o que inclui tanto as células NK quanto os linfócitos T CD8.

1.2 Células Natural Killer: Uma primeira linha de defesa do organismo contra vírus, bactérias intracelulares e células transformadas

Descritas pela primeira vez em 1975como "grandes linfócitos granulares" capazes de gerar uma resposta citotóxica rápida contra células tumorais $(10,11)$, as células NK foram posteriormente reconhecidas como uma linhagem diferente de linfócitos. Atualmente, entende-se que células NK são linfócitos efetores da imunidade inata eque reconhecem e eliminam de forma rápida células infectadas ou tumorigênicas, sendo ainda capazes de produzir quimiocinas e citocinas. Essas células possuem um repertório heterogêneo de receptores ativadores e inibidores codificados pela linhagem germinativa, e diferentemente dos linfócitos T CD8, não necessitam de ativação ou exposição prévia ao antígeno para se diferenciar em células efetoras (12). 
As células NK funcionam como sentinelas do sistema imune e parte desse trabalho deve-se a sua ampla distribuição pelo organismo, ocupando espaços em tecidos linfóides e não linfóides. Estudos mostraram que a frequência de células NK em camundongos é maior em órgãos não linfóides, principalmente nos pulmões e fígado (este fenômeno também é observado em humanos), sendo sua presença quase indetectável no timo. Apesar de amplamente distribuídas pelo corpo, os seus números são relativamente baixos quando comparados ao número total de linfócitos, representando uma fração de apenas $2 \%$ dos linfócitos no baço e $10 \%$ no pulmão de camundongos. No sangue periférico humano esse número varia de $2 \%$ a $10 \%$ (13).

Uma série de experimentos precursores revelou dados interessantes sobre a dinâmica espaço-temporal dessas células em seres humanos. Pesquisadores mostraram que células NK provenientes de doadores saudáveis em idade adulta proliferam a uma taxa de 4.3-6.7\% ao dia, com uma taxa de produção média de $15-23 \times 10^{6}$ células/dia, porém, esse valor pode chegar a $70 \times 10^{6}$ células/dia em indivíduos acometidos por infecções. Isso significa que essas células têm um tempo de turnover de aproximadamente duas semanas no sangue. Esses números podem sofrer variações com o efeito do envelhecimento ou infecções virais (14).

O desenvolvimento das células NK tem sido alvo de um grande número de estudos e seriam necessárias inumeráveis linhas para descrever com exatidão este processo. De maneira sucinta, sabe-se que as células NK desenvolvem-se na medula óssea a partir de células hematopoiéticas progenitoras CD34+. Células progenitoras linfóides comuns passam por um processo inicial de diferenciação, o qual pode gerar progenitores que podem se diferenciar em linfócitos T ou NK. Diversos fatores de transcrição que participam desse processo foram identificados, entre eles Ets-1. Estudos em camundongos revelaram que animais deficientes nesse fator apresentam números reduzidos de células NK no baço, além da citotoxicidade dessas células estar comprometida (15). Outro estudo revelou que camundongosnocautes para Ikaros possuíam células NK maduras deficientes, e estudos in vitro mostraram que isto estava relacionadoà ausência de precursores funcionais (16). A geração das células NK a partir desses precursores é marcada pela aquisição do receptor da subunidade beta de IL-2 (IL-2R $\beta$ ) e do receptor de IL-15 (IL-15R), denominado CD122 (17). Conforme as NKs amadurecem, elas adquirem receptores de ativação e de inibição. Por fim, 
essas células passam por um último estágio em que elas reconhecem moléculas próprias no MHC de classe I, processo conhecido como "educação" ou "licensing" (18). A diferenciação das células NK, bem como o fenótipo ao longo de diferentes estágios de vida dessas células pode ser vista na figura 1.

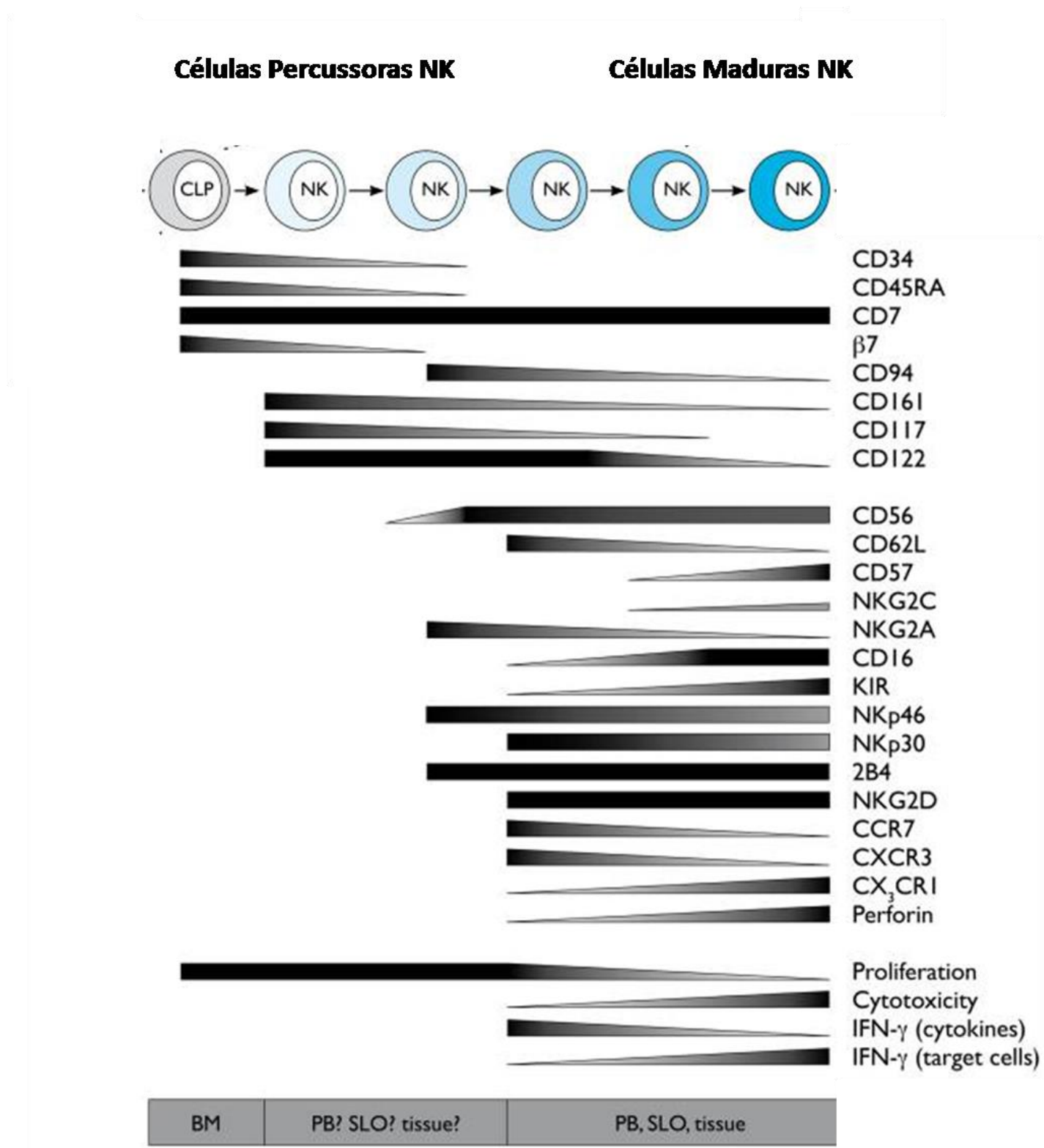

Figura 1-- Representação esquemática do desenvolvimento e diferenciação de células NK humanas. O desenvolvimento das células NK a partir do progenitor linfóide comum até uma célula terminalmente diferenciada dá-se da esquerda para direita na figura e está acompanhado da aquisição ou perca de marcadores e/ou propriedades funcionais. Os níveis de expressão das proteínas podem ser Vistos em preto (para altos níveis) e branco (para ausência de expressão). A cor cinza indica níveis intermediários. CLP (do inglês common lymphoid progenitor), BM (do inglês, bone marrow), PB (do inglês, peripheral blood), SLO (do inglês, secondary lymphoid organs). Adaptado de Romagnani C et al., 2013 (19) 
Receptores inibitóriosespecíficos para moléculas do $\mathrm{MCH}$ de classe I possuem uma cauda citoplasmática com motivos ITIMs (do inglês, immunoreceptor tyrosine-based inhibition motifs) e impedem que ocorra uma reação citotóxica indiscriminada por parte das células NK contra os tecidos autólogos. O ITIM contém uma tirosina que, após a ligação dos receptores inibitórios aos seus ligantes, é fosforilada por Src quinases, bloqueando a cascata de sinalização induzida pelos receptores ativadores. Vale ressaltar que a sinalização desses receptores desempenha um papel dominante sobre a sinalização dos receptores ativadores (20). Nos primatas, os receptores inibitórios que reconhecem o $\mathrm{MHC}$ de classe I pertencem à superfamília das imunoglobulinas KIR (do inglês, killer-cell inhibitory receptor). Esses receptores são codificados pelos genes KIR, presentes no cromossomo 19 e que apresentam graus variados de polimorfismo (21). Outros receptores como LILR (do inglês, Leukocyte Immunoglobulin-like Receptor) e NKG2A (CD94) também podem reconhecer o MHC de classe I. Embora existam diferentes receptores inibitórios que reconheçamoutras moléculas próprias, os receptores que reconhecem as moléculas do MHC de classe I são considerados os mais importantes para manutenção da autotolerância (figura 2). Nos roedores, a família de receptores que reconhece o MHC de classe I é conhecida como Ly49 e possui propriedades semelhantes aos receptores humanos.
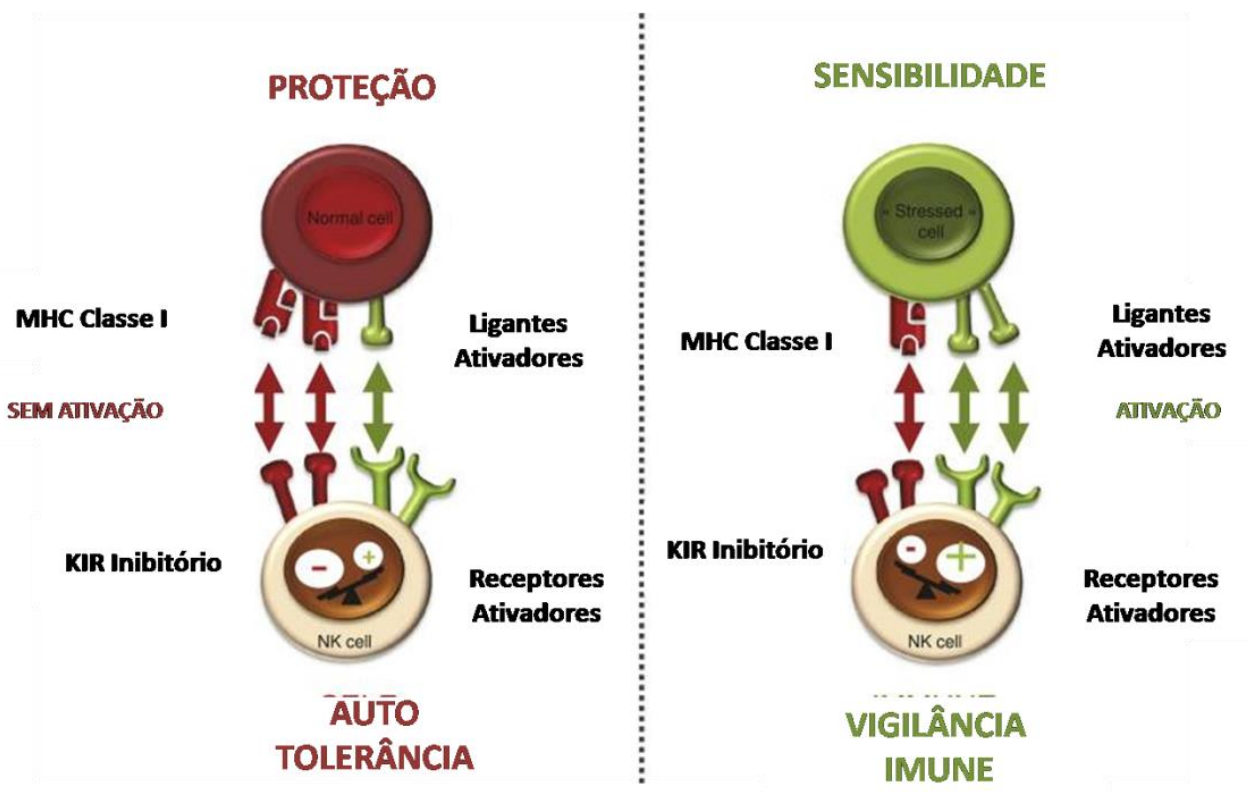

Figura 2 - Estratégias de reconhecimento das células NK. As células NK reconhecem seus alvos por meio de receptores ativadores e inibitórios. Uma vez que a sinalização inibitória prevalece, o resposta gerada é de tolerância. Já quando os sinais ativadores prevalecem a célula é ativada e entra em um estado de vigilância imonológica . KIR (do inglês, killer cell immunoglobulin-like receptor). Adaptado de Vivier E. et al, 2011. (22) 
Ao contrário dos linfócitos $T$ e $B$, que possuem um receptor que domina sua ativação, podendo ainda esta ativação ser potencializada por moléculas coestimulatórias, nas células NK a ativação é mediada pela sinalização de diversos receptores. Um grande número de receptores estruturalmente distintos tem sido descritos na ativação das funções efetoras das células NK. Esses receptores podem ser agrupados em três categorias: Receptores que sinalizam via ITAM (do inglês, immunoreceptor tyrosine-based activation motif) (por exemplo, CD16, NKp46, NKp44); receptores associados à molécula DAP10 (NKG2D) e receptores que sinalizam por outras vias (CD2, 2B4, DNAM-1) (23). A ativação das células NK promove a reorganização do citoesqueleto, que culmina na polarização da célula para liberação dos grânulos citotóxicos contendo principalmente perforina e granzimas sobre a célula alvo. Além disso, há transcrição de uma série de genes para expressão de citocinas e quimiocinas.

Receptores ativadores das células NK interagem com ligantes em células alvo, como os ULBP e MIC em humanos, bem como as moléculas RAE1, H60 e MULT1 em murinos, moléculas estruturalmente homólogas ao MHC de classe I e reconhecidas por receptores como NKG2D. Outras moléculas de alerta incluem ligantes de TLRs e ligantes como a molécula de superfície celular m157 codificada pelo citomegalovirus e reconhecida em murinos pelo Ly49H durante uma infecção. Além desses, as células NK também podem expressar receptores Fc de baixa afinidade como CD16, permitindo a elas reconhecerem células alvo revestidas por anticorpos e, dessa forma, exercerem citotoxicidade celular dependente de anticorpo (ADCC) (24) (Figura 3). 


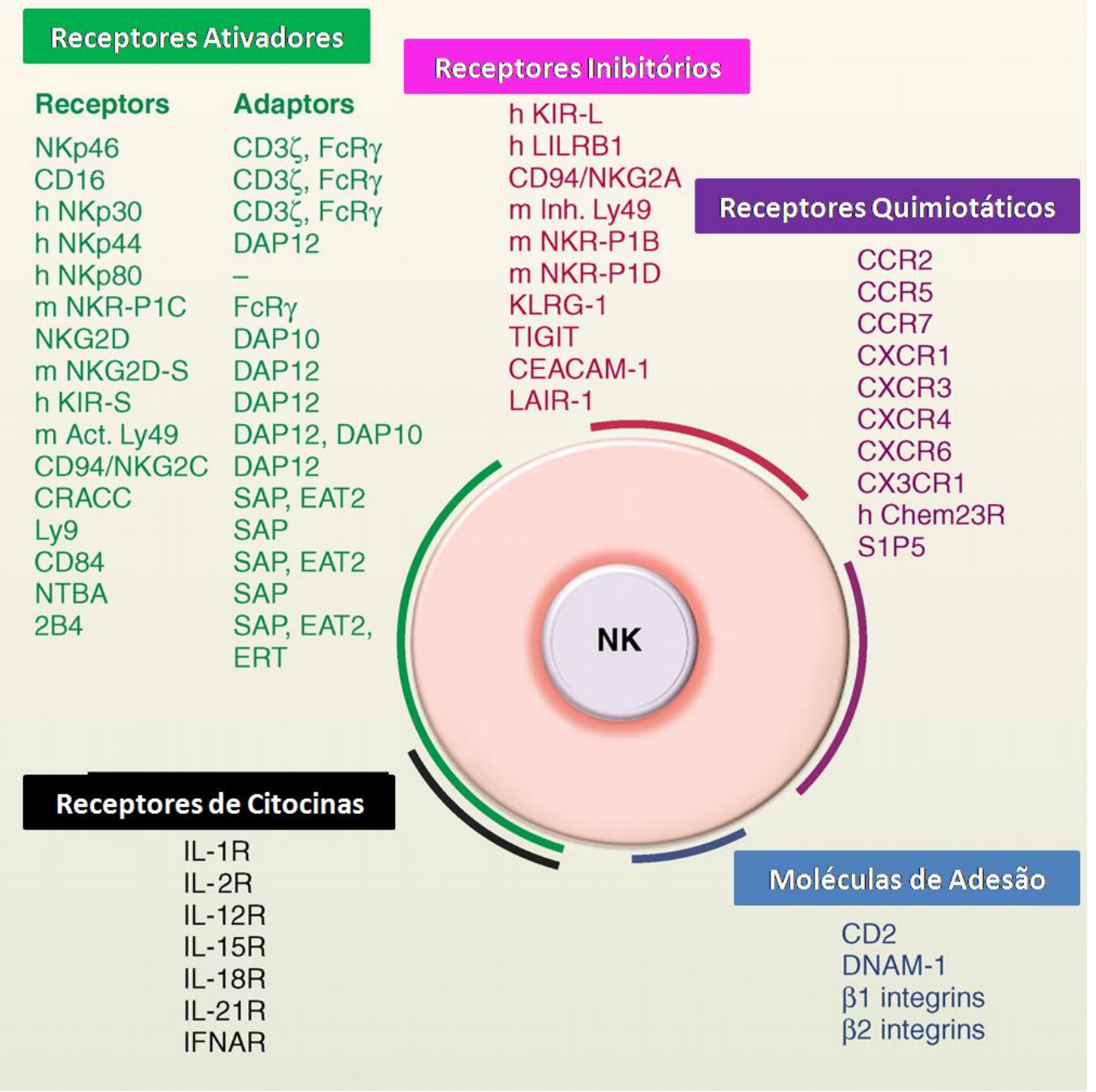

Figura 3- Receptores das células NK humanas e murinas. As células NK expressam diferentes receptores que podem ser agrupados em ativadores (verde), inibitórios (vermelho), moléculas de adesão (azul), citocinas (preto) e receptores quimiotáticos (roxo). Moléculas adaptadoras envolvidas na sinalização downstream dos receptores ativadores também estão indicadas em verde. A menos que esteja indicado com $\mathrm{h}$ para humanos e $\mathrm{m}$ para murinos, as moléculas são conservadas em ambas as espécies. Adaptado de Ugolini S. et al., 2011 (25).

A região de contato entre uma célula NK e uma célula alvo é denominada sinapse imunológica e esta região é fundamental para o desenvolvimento das funções efetoras dessas células (figura 4). Experimentos utilizando avançadas técnicas de microscopia demonstraram que a sinapse imunológica das células NK pode ser dividida em dois domínios distintos. O primeiro deles é o domínio de ativação supramolecular periférica (pSMAC), que forma um anel na região de contato entre as células alvo e NK, e que contém moléculas de adesão, tais como LFA-1 (do inglês, lymphocyte function-associated antigen 1) e envolve a acumulação dos filamentos de actina nessa região. O segundo é odomínio de ativação 
supramolecular central (cSMAC)e é o local onde ocorre a exocitose dos grânulos citotóxicos, concentrando a liberação desses grânulos sobre a célula alvo (26).

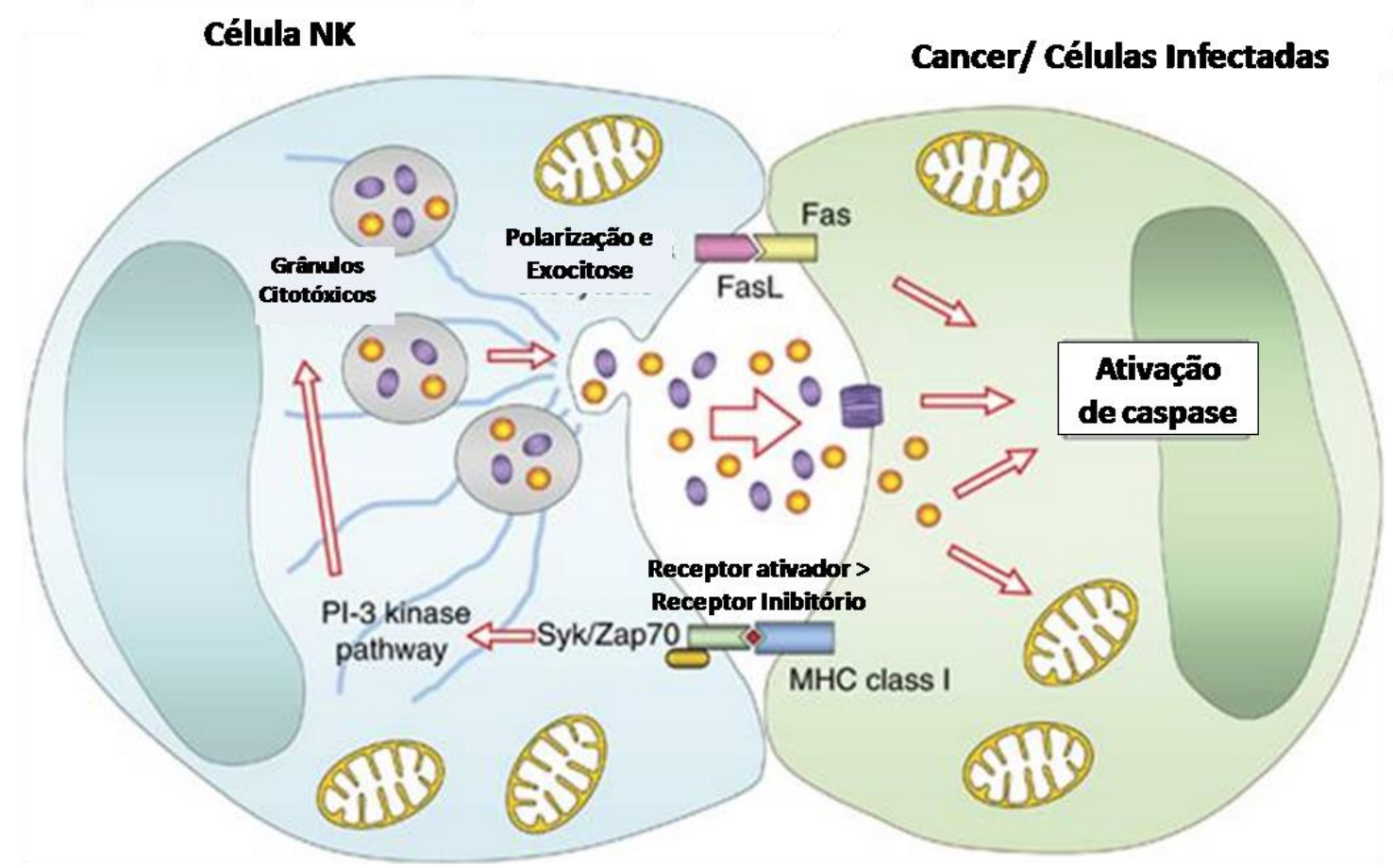

Figura 4 - A via de exocitose dos grânulos. De acordo com esse modelo, a capacidade das células NK eliminarem seus alvos reside nos grânulos citotóxicos pré formados contendo moléculas como perforina e granzima presentes no citoplasma dessas células e que são prontamente secretados quando estas células são ativadas. Adaptado de Trapani JÁ, 2012 (27).

"Armed and ready!" (armado e pronto!), é assim que os pesquisadores descrevem a condição das células NK (28). Isso não significa que a citotoxicidade exercida por essas células seja um processo indiscriminado ou sem pontos de controle, muito pelo contrário, já foram descritos mais de 48 passos subdivididos em três categorias (reconhecimento, fase efetora e fase terminal), que são finamente controlados e central a essa regulação está a sinapse imunológica. Esses processos foram brilhantemente revisados por Orange, J. S. et al., (2014) (29).

Uma série de estudos publicados por Long e colaboradores no ano de 2006 resultaram na introdução de um novo conceito no universo das células NK, trata-se do conceito de coativação. Nesse estudo, os pesquisadores mostraram que ao submeter células NK humanas isoladas de pacientes a um tratamento com anticorpos agonistas para os receptores ativadores, nenhum deles sozinhofoi capaz de gerar resposta efetora, com exceção do CD16. Entretanto, ao utilizar diferentes combinações de pelo menos dois agonistas, as funções efetoras eram ativadas, evidenciando um sinergismo entre os 
receptores. Por fim, os autores observaram que existe certo limiar de sinalização que precisa ser alcançado para ativar as funções efetoras e esse limiar deve ser superior aos sinais emitidos pelos receptores inibitórios (30).

Outro tópico interessante a ser abordado no universo das células NK é o conceito de memória. A memória imunológica pode ser definida como uma melhora em termos de qualidade e quantidade das respostas imunes após o reencontro com um agente que desencadeou a resposta. Essa é uma das características básicas atribuída às células da imunidade adquirida como linfócitos $T$ e $B$, entretanto, evidências crescentes têm demonstrado que células da imunidade inata também podem apresentar uma habilidade semelhante a esta após encontros com determinados estímulos (31).

Em um artigo seminal publicado em 2006, pesquisadores reportaram a primeira observação de memória imunológica em células NK de mamíferos. No artigo os pesquisadores mostraram que animais desprovidos de linfócitos $T$ e $B$ apresentaram hipersensibilidade de contato a haptenos (respostas tradicionalmente desenvolvidas pelas células anteriormente citadas). Além disso, tais respostas ocorreram em animais que receberam transferência adotiva de células NK de animais doadores previamente sensibilizados. Os autores observaram pela primeira vez em vertebrados superiores que células NK podem mediar respostas antígeno-específicas de longa duração típicas da imunidade adquirida, independentemente da presença de linfócitos T e B (32). Após a introdução do conceito de memória imunológica em células NK, vários outros grupos publicaram outros artigos reforçando esse conceito e estendendo essa propriedade a outras doenças. Mais recentemente outro estudo revelou que esta propriedade também está presente em primatas. Neste estudo, células NK de macacos rhesus vacinados com vírus da imunodeficiência símia (SIV) foram capazes de eliminar eficientemente alvos específicos mesmo após cinco anos após a imunização, revelando a robustez e duração da memória induzida em primatas, sendo este um importante achado que pode contribuir no desenvolvimento de vacinas contra HIV-1 e outros patógenos (33).

Assim como em outros tipos celulares, diferentes subtipos de células NK têm sidodescritos de acordo com a expressão de receptores de superfície, potencial migratório, proliferação, localização anatômica e hospedeiro (humano, murino, etc...). Esse assunto, 
entretanto, ainda é um tanto quanto controverso e não existe nenhum consenso sobre marcadores específicos para cada subtipo. No entanto, foram descritas subpopulações de células NK em camundongos com base na expressão das moléculas de CD11b e CD27 (34), enquanto em humanos foram descritas subpopulações com base na expressão de CD56 (35). Esses dados indicam que as células NK compreendem uma população muito mais heterogênea do que se acreditava inicialmente.

\subsection{Linfócitos T CD8: Potentes Matadores Da Imunidade Adaptativa}

O desenvolvimento das células T CD8 inicia-se no timo, a partir de células progenitoras provenientes da medula óssea, e envolve a aquisição de um TCR que se encaixa perfeitamente com as formas alélicas das moléculas de MHC de classe I expressas no indivíduo. Antes que esses linfócitos deixem o timo, as células que reconhecem moléculas próprias com alta afinidade ou que expressam rearranjos do TCR não funcionais são deletadas do repertório. Dessa forma, as células T CD8 naïves que deixam o timo em direção a corrente sanguínea são células autotolerantes e restritas ao MHC próprio (36).

Estudos recentes estão ajudando a identificar os mecanismos por trás do comprometimento de células T em desenvolvimento com a linhagem CD8. A ideia aceita atualmente é ade que o comprometimento com a linhagem CD8 resulte da ação do repressor transcricional Runx3, regulado positivamente nas células restritas ao MHC de classe I e que juntamente com a proteína relacionada RUNX1, reprimem a ação dos genes Thpok e $\mathrm{Cd} 4$, inibindo, consequentemente, o comprometimento com a linhagem CD4. Foram descritos também dois fatores críticos para expressão do Runx3, o Stat5 (alvo da sinalização de IL-7 no timo) e Ets1, molécula expressa em todos os estágios do desenvolvimento das células $T$, que se liga ao lócus do Runx3 promovendo sua expressão. Além disso, Ets1 contribui para expressão do receptor de IL-7 (37). Runx3 também regula a expressão do fator de transcrição T-box Eomesodermina (Eomes), importante no processo de diferenciação dos linfócitos T CD8 em células efetoras e de memória (38).

Diferentes subtipos de linfócitos T CD8 podem ser encontrados circulando na periferia e esses subtipos representam diferentes estágios dessas células. Uma ferramenta bastante poderosa e versátil utilizada para diferenciar essas populações é a citometria de 
fluxo. Diversos marcadores têm sido utilizados na classificação dessas células, dentre os quais podemos destacar o CD8, o CD27 e o CD45. Linfócitos T CD8 naïve são células que apresentam-se $C D 8^{+} \mathrm{CD} 27^{+} \mathrm{CD} 45 \mathrm{RA} A^{+}$, já as células efetoras são células que expressam o perfil $C D 8^{+} C D 27^{-} C_{45} 4 A^{+}$, enquanto que células de memória são células $\operatorname{CD}^{+} C D 45 R 0^{+}$(a função desses marcadores está descrita nas próximas linhas). Entretanto, outros marcadores podem ser utilizados para identificar essas populações (39).

Linfócitos T CD8 naïves, ao interagir com células dendríticas em órgãos linfóides secundários sofrem um processo de expansão massivo, tornando-se potentes células efetoras, capazes de migrar para as mais diversas regiões do organismo. Estas células podem ainda continuar interagindo com DCs e outras células do sistema imune no sítio alvo da resposta e dar continuidade ao processo de expansão ou diferenciação (40).

De acordo com a teoria da seleção clonal, as respostas imunes adaptativas evoluem após a exposição a antígenos, de modo que as células que possuem um receptor específico para um determinado antígeno são ativadas após essa exposição, proliferam e diferenciamse em efetoras. Essa habilidade é facilmente observada em respostas a infecções virais, particularmente no compartimento dos linfócitos T CD8. Foi observado que pacientes com infecções virais na fase aguda (momento em que o vírus se replica sistemicamente em uma taxa elevada) apresentam um aumento substancial dos linfócitos T CD8, como é o caso dos portadores dos vírus da imunodeficiência humana (HIV), Epstein-Barr (EBV), e citomegalovírus (CMV), podendo essas células inclusive superar em quantidade os linfócitos T CD4 (41-43).

O avanço de tecnologias como o desenvolvimento de complexos multiméricos de MHC, o aperfeiçoamento e expansão da citometria de fluxo, além da geração de linhagens animais TCR-transgênicas têm contribuído com os estudos sobre a biologia das células efetoras e de memória e mostrado que capacidade de gerar células efetoras de vida curta, essenciais para as defesas durante a fase aguda de infecções, bem como células de vida longa, que formam o compartimento de células de memória, importantes para exposições posteriores ao mesmo antígeno, conferem grande eficiência às respostas mediadas pelos linfócitos T CD8(44). 
A caracterização fenotípica em células efetoras ou de memória é baseda na expressão de alguns receptores e moléculas. Podemos destacar entre esses o CD45RA, uma das duas isoformas do CD45, que pode ser encontrado em linfócitos T CD8 efetores assim como CD27 e CD28. O CD27 é uma molécula regulada positivamente após a estimulação do TCR dos linfócitos T CD8 e liga-se ao CD70. Embora seu papel seja pouco conhecido, estudos mostram que essa molécula é necessária para a geração de células de memória. O CD28 é uma molécula coestimuladora que se liga ao CD80 (B7-1) e CD86 (B7-2), ambos expressos nas APCs. É necessária a ligação do CD28 concomitante com o reconhecimento do antígeno para que haja a ativação do linfócito, havendo regulação negativa dessa molécula após esse processo. Outro parâmetro que pode ser utilizado para análise fenotípica de diferentes subpopulações de linfócitos T CD8 é a expressão de receptores quimiocinas. Um exemplo ilustrativo disso é o CCR7. O CCR7 funciona como um receptor que auxilia na migração de células naïve e de memória para órgãos linfóides secundários. A produção de perforina também é utilizada para essa avaliação, bem como a produção de citocinas como IFN- $\gamma$, TNF$\alpha$ e MIP-1 $\beta$ (45).

Existem diferentes modelos tentando explicar os mecanismos pelos quais uma célula T CD8 pode tornar-se uma célula efetora ou uma célula de memória, entretanto, todos apresentam pontos questionáveis. A teoria conhecida como "modelo da diferenciação"articula que as células efetoras precedem as células de memória no curso de uma resposta imune. Simpatizantes deste modelo defendem que células de memória são células descendentes de células efetoras citotóxicas e que de alguma maneira escapam da morte celular induzida por ativação (AICD), diferenciando-se em células de vida longa (46). Já o "modelo da diferenciação progressiva" é reforçado por uma série de estudos e afirma que fatores como a intensidade do estímulo via TCR, moléculas coestimulatórias, citocinas e sinais provenientes do microambiente, juntos determinam se uma célula se diferenciará em efetora (estímulosfortes) ou uma célula de memória (estímulosfracos) (47 e 48).

Para que ocorra a conversão completa dos linfócitos T CD8 naïves em células efetoras são necessários três sinais: O reconhecimento do antígeno, sinais coestimulatórios e a sinalização por determinadas citocinas. Entre as citocinas mais importantes para o estabelecimento de uma resposta efetora ótima podemos destacar a IL-12, produzida por células dendríticas ativadas. Estudos mostraram que a ausência de IL-12 pode gerar uma 
resposta abortiva, ou seja, células com baixo potencial citotóxico e expansão clonal deficiente, embora os autores concordem que a sinalização da IL-12 possa estar mais ligada à sobrevivência dos linfócitos TCD8 do que diretamente a divisão celular (49).

$\mathrm{Na}$ presença dos estímulos corretos, as células sofrem expansão; adquirem a capacidade de eliminar alvos através da produção de moléculas citotóxicas e/ou ligantes capazes de induzir a morte; percorrem os sítios de infecção espalhados pelo organismo, podendo ainda secretar citocinas e regular positivamente de adesão e receptores de quimiocinas. A integrina $\alpha 4 \beta 7$ e o CCR9 estão relacionados com a migração dos linfócitos T CD8 ao intestino, enquanto os ligantes para P-selectina e para E-selectina são necessários para a migração desses linfócitos para a pele. A migração dos linfócitos T CD8 para distintos sítios inflamatórios envolve a participação da integrina $\alpha 4 \beta 1$ e dos receptores de quimiocinas CXCR3, CCR3, CCR5 e CCR8 (50).

Com base nas características anteriormente citadas das células efetoras ativadas, especialistas da área concordam em classificar estas células como linfócitos T citotóxicos (do inglês,cytotoxic T lymphocytes, CTL). Os CTLs podem causar a morte das células alvo por dois mecanismos diferentes: $\mathrm{O}$ primeiro deles é a morte dependente de $\mathrm{Ca}^{2+}$ e envolve a transferência do conteúdo dos grânulos citotóxicos para a sinapse imunológica. Já o segundo mecanismo, independente de $\mathrm{Ca}^{2+}$, é mediado pela expressão de ligantes da superfamília do fator de necrose tumoral (TNF), tais como o próprio TNF- $\alpha$, TRAIL e FASL. Ambas as vias desencadeiam a apoptose, entretanto, a via dos grânulos é tipicamente mais rápida e eficiente. A morte mediada por grânulos tem um aspecto mais geral, uma vez que não necessita de receptores específicos, e através da perforina causa danos à membrana, permitindo a entrada de granzimas no citoplasma da célula alvo. O FASL tem sido reportado em grânulos de células citotóxicas que coexpressam perforina e granzimas, podendo também ser exocitado na fenda sináptica em resposta à ativação do TCR (51 e 52).

Um parêntese importante a ser destacado e que está sob constante revisão na literatura é o envolvimento dos linfócitos T CD4 na geração de CTLs. Alguns autores defendem a teoria de que os linfócitos T CD4 "licenciam" as DCs via CD40/CD40L para que estas possam apresentar antígenos de maneira cruzada aos linfócitos T CD8 (53). Embora esse estudo tenha revolucionado o campo da imunidade adaptativa, outros autores 
questionam as condições estéreis em que o estudo foi realizado, muito diferente da realidade que se encontra nos organismos vivos, nos quais altos níveis de inflamação estão presentes concomitantemente com a apresentação do antígeno. Nesses ambientes as DCs podem ter contato com uma grande diversidade de PAMPs e com isso, serem ativadas diretamente via TLRs, não sendo então necessário o auxílio de linfócitos T CD4 para "primar" as CTLs (54). Dados do nosso grupo mostram um terceiro cenário em que mesmo na presença de agentes inflamatórios, como componentes virais, as funções das CTLs estão parcialmente comprometidas em camundongos CD4 KO (Amarante-Mendes et al., dados não publicados). Sendo assim, o papel dos linfócitos T CD4 nas respostas citotóxicas permanece uma questão em aberto e um campo fértil para estudos das funções dessas células.

Estudos elegantes utilizando modelos animais mostraram que um camundongo não infectado possui entre 100-1000 linfócitos T CD8 epítopo-específicos, espalhados numa população total de 2,4-3 × 107 T CD8 naïves, com um repertório de aproximadamente $2 \times 10^{6}$ diferentes TCRs. Esses números são significativamente alterados após uma infecção viral, em que a população específica de linfócitos T CD8 aumenta seu tamanho cerca 2300 vezes após cinco dias do início da infecção, dobrando seus números a cada 6-8 horas. No pico dessa resposta viral (oito dias do início da infecção), a população específica pode ser 50000 vezes maior do que num animal não infectado, podendo ter alcançado 14 ciclosde proliferação. Esse pico da resposta coincide com a eliminação do vírus e das células infectadas e dá-se então início a uma fase de contração da resposta (55-57).

A fase de contração da resposta citotóxica é caracterizada por apoptose das CTLs, restando uma pequena fração de 5\%-10\% do número de células que existiam no pico da resposta. As células que sobrevivem possuem propriedades especiais e vão formar o repertório de células de memória do organismo. Após este período, os números de células de memória são mantidos estáveis pelo resto da vida em camundongos ou por muitos anos em humanos (células de vida longa), e estas células são capazes responder a exposições posteriores a esses mesmos antígenos, gerando respostas mais rápidas e robustas. Tal característica pode ser evidenciada, por exemplo, por um estudo recente que revelou que cerca de $50 \%$ dos pacientes vacinados contra a varíola entre 51-75 anos atrás e que tomaram uma única dose da vacina durante a vida, ainda possuem linfócitos T CD8 
específicos no organismo; no caso de indivíduos que tomaram duas doses de vacina, esse número sobe para quase $60 \%$ (58).

De acordo com o seu fenótipo e suas funções, as células T CD8 de memória podem ser subdivididas em dois grupos. As células $T$ de memória central $\left(T_{\mathrm{cm}}\right)$ e as células $T$ de memória efetoras $\left(T_{\mathrm{em}}\right)$. As primeiras geralmente residem em órgãos linfóides, expressam CCR7 e CD62L (L-selectina), produzem IL-2, possuem alta capacidade proliferativa, porém, não apresentam a maquinaria citotóxica. Já as Tem não expressam esses marcadores, estão presentes em tecidos não linfóides, proliferam em uma intensidade menor, possuem a maquinaria citotóxica pronta para responder e produzem citocinas como INF- $\gamma$. Existe ainda uma terceira população que apresenta características mistas das outras duas populações (59 e 60). Essas células estão frequentemente localizadas em regiões expostas a patógenos microbianos como pele e intestino, atuando de maneira que exposições posteriores aos patógenos possam ser controladas muito mais rapidamente, e diminuindo os riscos de que o processo infeccioso chegue ao ponto de causar danos irreversíveis ao hospedeiro.

Estudos atuais têm discutido não só sobre a diversidade de células de memória como também das respostas dos clones dos linfócitos T CD8 efetores em animais. Um estudo precursor analisou no ano de 2007 diferentes aspectos da resposta ao vírus HIV em humanos e comparou a diversidade da resposta mediada por linfócitos T CD8 ao vírus em pacientes infectados em estágio crônico e pacientes "não progressores de elite" (pacientes portadores do vírus, porém, que não manifestam os sintomas da doença e mantém os títulos virais baixos). Nesse estudo observou-se que nos pacientes não progressores existe uma manutenção preferencial de células HIV-específicas com alta capacidade funcional (CD107a ${ }^{+}$, IFN- $\left.\gamma^{+}, \mathrm{MIP}-1 \beta^{+}, \mathrm{IL}-2^{+}, \mathrm{TNF}-\alpha^{+}\right)$, embora as frequências totais de células específicas entre os dois grupos fossem iguais. Esse estudo mostrou que além de existir diversidade entre as populações de um mesmo clone, essa diversidade tem uma importância fundamental no desenvolvimento da resposta(61).

Utilizando protocolos de infecções virais em modelos animais foi observado quão uniformes e reprodutíveis são os padrões de resposta dos linfócitos T CD8, (62). Esses padrões teoricamente evidenciam um comportamento que é reflexo das respostas em nível de células individuais, ou seja, espera-se que o comportamento de uma única célula (e seus 
descendentes) seja estereotipado e siga padrões comportamentais regulares. Entretanto, estudos mais refinados demonstram que as respostas individuais dos linfócitos T CD8 podem ser altamente variáveis. Em uma série de experimentos elegantes utilizando a tecnologia do DNA-barcode, um grupo da Holanda demonstrou, também in vivo, o tamanho da heterogeneidade das respostas dos linfócitos T CD8 em nível de uma única célula, evidenciando que a progênie de uma célula pode apresentar diferentes padrões de expansão clonal e de diferenciação, mesmo elas possuindo um TCR idêntico (63). Esse trabalho levanta uma interessante questão acerca das respostas dos linfócitos T CD8, sendo ainda desconhecido como estas respostas podem ser tão reprodutíveis em termos de organismo, havendo tanta heterogeneidade a nível celular.

De forma geral, os linfócitos T CD8 agem no organismo por três mecanismos. O primeiro deles é através da secreção de citocinas como TNF- $\alpha$ e INF- $\gamma$. O TNF- $\alpha$ ao encontrar o seu receptor na membrana da célula alvo ativa a via das caspases levando esta à apoptose. O INF- $\gamma$, por sua vez, induz a ativação transcricional da via de apresentação do MHC de classe I e do FAS, o que aumenta a apresentação de peptídeos endógenos pela via do MHC de classe I e promove a morte mediada por FAS na célula alvo. Os outros dois mecanismos dependem de contato entre célula efetora e célula alvo. Um deles trata-se da expressão de FASL (CD95) na superfície das CTLs, que se liga ao receptor FAS na célula alvo, promovendo a ativação da via das caspases e consequente morte por apoptose. O outro mecanismo

consiste na liberação de grânulos citotóxicos contendo granzimas, perforina e outras moléculas na região de contato entre a célula alvo e a célula efetora, região conhecida por sinapse imunológica (64). Alguns autores consideram este o mecanismo mais eficiente por meio do qual as CTLs eliminam as células infectadas.

\subsection{Grânulos Citotóxicos}

O tráfego intracelular é um processo fundamental para as células eucarióticas, em especial para as células do sistema imune. A maior parte das células deste sistema são células especializadas com capacidade de secretar um vasto número de moléculas. Esse processo é em geral mediado pelo transporte de vesículas, que compreende desde o direcionamento de moléculas para o interior dos grânulos secretórios até a liberação do seu conteúdo no destino final. Entre o início e o final dessas vias, existe ainda uma série de 
etapas intermediárias, sendo todas elas reguladas por um grande número de proteínas adaptadoras, GTPases e SNAREs(soluble N-ethyl maleimide sensitive factor (NSF) attachment protein receptor), a fim de garantir o funcionamento perfeito dessa maquinaria.

Nos linfócitos T CD8 os grânulos citotóxicos foram classificados como lisossomos secretórios ou organelas relacionadas aos lisossomos, porque além de funcionar como lisossomos convencionais, cujo lúmem é ácido e contém hidrolases lisossomais típicas e outras moléculas, podem também armazenar moléculas citotóxicas e utilizam um sistema de transporte especial, que permite a secreção regulada, culminando com a fusão destes com a membrana plasmática. Ao contrário de outras células que contém tanto lisossomos convencionais quanto os lisossomos secretórios, como os melanossomos, os grânulos citotóxicos parecem ser as únicas organelas da classe dos lisossomos presente em células T CD8 maduras e NK (65).

Os linfócitos T CD8 e as células NK utilizam a mesma estratégia rápida e eficiente de ação efetora, consistindo principalmente na secreção polarizada de mediadores citotóxicos armazenados nos lisossomos secretórios, também conhecidos como grânulos citotóxicos. Apesar disso, os mecanismos utilizados por essas células para reconhecer alvos são diferentes. Enquanto em linfócitos T CD8 a ligação aos receptores de antígenos específicos rearranjados somaticamente determina a ativação e ação dessas células, nas células NK o que determina a ação é o balanço entre sinais ativadores e inibitórios dos receptores codificados pela linhagem germinativa (66), conforme discutido nos itens anteriores.

Em um estudo precursor publicado em 2013, pesquisadores realizaram uma série de experimentos comparando propriedades dos grânulos citotóxicos dos linfócitos T CD8 e das células NK. Nesse estudo demonstrou-se que ambas as células possuem capacidades semelhantes de degranular e de eliminar células alvo, embora a expressão de alguns dos seus componentes seja diferente (67). Outros estudos mostraram ainda que os linfócitos T CD8 e as células NK parecem compartilhar a mesma maquinaria de exocitose de grânulos citotóxicos (68).

Os grânulos citotóxicos possuem uma constituição complexa e diversificada. Em sua membrana estão presentes moléculas como a proteína FASL (CD178) e a molécula coestimulatória negativa CTLA-4 (CD152), além das proteínas de membrana associadas aos 
lisossomos LAMP-1 (CD107a), LAMP-2 (CD107b) e LAMP-3 (CD63) (69). Quanto às proteínas de matriz, estão presentes perforina, granulisina e granzimas, responsáveis pela lise da célula alvo. As granzimas A e B são as granzimas mais abundantes em seres humanos e muita atenção tem sido dada a granzima B, porque ela ativa a via de apoptose dependente de caspase, e similarmente às caspases, cliva resíduos de ácido aspártico (70). Podem ser encontrados ainda nesses grânulos proteínas como a catepsina B e $D, \beta$-hexosaminidases além de proteoglicanas e serglicinas que desenvolvem uma função importante durante o armazenamento dos diferentes componentes dos grânulos (71).

Existem alguns modelos tentando descrever a biogênese dos grânulos citotóxicos. Um grupo de autores sugere que precursores dessas organelas surgem por brotamentos do compartimento Trans-Golgi-Network (TGN). Outros autores sugerem, baseados na semelhança dos grânulos citotóxicos com lisossomos convencionais, que os endossomos desempenham um papel fundamental na biogênese dessas organelas e essa parece ser a hipótese mais aceita. Em resumo, um passo inicial na formação dos grânulos citotóxicos envolve a fusão de endossomos de reciclagem contendo RAB11 e MUNC13-4 com endossomos tardios, caracterizados pela presença de RAB27A e RAB7. A fusão dessas estruturas parece fornecer proteínas que ajudam na regulação do tráfego de vesículas em estágios mais tardios como LAMP-1 e LAMP-2. Somado a isso, a presençade proteínas adaptadoras na superfície dos grânulos permite que ocorra o encaminhamento de diferentes moléculas para o interior dos mesmos (72). A dinâmica de enriquecimento dos grânulos citotóxicos, porém, ainda não foi completamente caracterizada.

A secreção direcionada de grânulos pelas células do sistema imune é um evento complexo que requer uma série de passos que culminamcom a polarização celular e, consequente formação da sinapse imunológica, criando uma região de contato íntima entre a célula alvo e a célula efetora (figura 5). O evento central por trás da secreção de grânulos foi observado inicialmente em linfócitos T CD8 ativados, e posteriormente em linfócitos T CD4, células NK e NKT, e consiste na migração do centrossomo, ou centro organizador de microtúbulos (MTOC), para a região da sinapse imunológica, mais especificamente próximo a área do CSMAC,evento que se demonstrou ser dependente de ERK, Vav1, Pyk2 e hDia1, e essa movimentação dá-se por meio da interação do centrossomo com proteínas motoras e o citoesqueleto (73). Como resultado disso, o MTOC não apenas se polariza na direção da 
célula alvo, mas também entra em contato com a membrana plasmática do linfócito T CD8 ativado, permitindo dessa maneira que os grânulos possam ser entregues diretamente na membrana plasmática da célula efetora à medida que eles alcançam o MTOC polarizado (74).Estudos mostraram que a movimentação dos grânulos citotóxicos em direção ao MTOC é dependente de uma proteína motora denominada dineína (75).
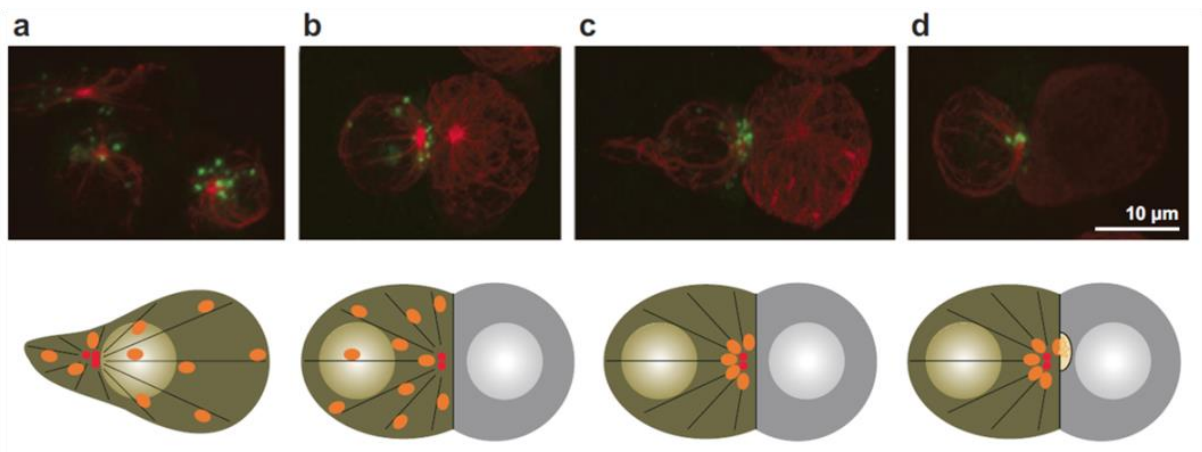

- Grânulo Citotóxico

- мтос

Microtúbulo Fenda Sináptica

Figura 5 - Polarização dos grânulos citotóxicos em direção a sinapse imunológica de uma célula citotóxica ativada. As imagens de fluorescência (topo) e os desenhos esquemáticos (abaixo) os estágios da polarização. Na ausência de uma célula alvo, o MTOC possui uma localização perinuclear e os grânulos citotóxicos estão distribuídos ao longo dos microtubulos por toda a célula. Ao encontrar uma célula alvo, a rede de microtúbulos polariza-se em direção ao alvo e os grânulos se movem em direção ao MTOC, onde liberam o conteúdo dos grânulos que atingem a membrana da plasmática da célula alvo, desencadeando a apoptose da mesma. Adaptado de Griffiths GM et al., 2006 (76).

Os estudos dos componentes necessários para fusão de membranas biológicas em células de eucariotos têm destacado a importância dos SNARE. Em muitos, senão em todos os eventos de fusão de membranas, as proteínas SNARE e seus reguladores são essenciais para a fusão rápida, direta e controlada das membranas fosfolipídicas (77). As proteínas da família dos SNARE necessárias para a degranulação das células citotóxicas incluem VAMP7, que está associada aos grânulos citotóxicos, bem como sintaxina-11 e Munc18-2, que interagem para conduzir a fusão das membranas e subsequentemente, exocitose dos grânulos. (78).

A utilização de técnicas de proteômica tem ajudado nos estudos da maquinaria envolvida no tráfego dos grânulos citotóxicos, assim como tem revelado novos candidatos envolvidos nesses processos. Espera-se que a caracterização funcional desses candidatos possa fornecer maiores informações acerca da função dos grânulos citotóxicos a nível molecular, aprofundando o entendimento sobre essa organela (79). Estudos prévios realizados por nosso grupo utilizando esta mesma metodologia identificaram moléculas bem descritas na literatura comoLAMP-1, perforina e granzima B em grânulos citotóxicos de células citotóxicas, além de novas proteínas nunca antes relatadas nesse contexto 
(Amarante-Mendes et al., dados não publicados) (Apêndices 1 e 2).Entre essas novas moléculas, uma família de proteínas denominada RAB chamou a atenção do nosso grupo, devido à importância cada vez maior que essas proteínas têm adquirido nos processos de tráfego intracelular, e, por esse e outros motivos que serão entendidos nos próximos parágrafos, quatro membros dessa família foram escolhidos para estudo nestatese de doutorado.

\subsection{RAB GTPases: Organizando O Tráfego Intracelular Desde Os Primórdios Da Vida}

Um dos principais eventos de natureza evolutiva que ocorreu durante a história dos seres vivos foi a eucariogênese, que culminou com o surgimento de células nucleadas. Acompanhando esse evento surgiu ainda a compartimentalização celular, característica até então inexistente em Archea e Eubacterias, isto permitiu a separação dos principais processos bioquímicos intracelulares e um controle mais refinado das vias metabólicas. Esse novo sistema de endomembranas, com origem distinta de organelas endosimbióticas como mitocôndrias e cloroplastos, está envolvido na biossíntese, direcionamento e reciclagem de componentes da superfície celular, bem como na endocitose e degradação de moléculas. Devemos ainda observar que as vias de tráfego intracelular representam um avanço considerável de complexidade e diversidade em termos de mecanismos, funções e morfologia celular. Essa diversidade pode ser vista tanto entre organismosdiferentes como entre distintos tipos celulares de organismos multicelulares. Por fim, esse complexo sistema de tráfego intracelular foi uma importante adaptação dos seres unicelulares e permitiu a divisão do trabalho nos animais superiores e plantas. Não é de se espantar que o sistema de endomembranas ocupe uma grande porcentagem do genoma dos eucariotos, sendo compreendido por membros da família dos SNARE, ARF, GAPs (GTPase-activating proteins), RABs e muitos outros (80).

A quantidade de dados do genoma dos mais diferentes organismos atualmente disponível tem permitido a realização de estudos de genética comparativa que estão ajudando a entender a origem do sistema de endomembranas. Está cada vez mais claro que essa origem é bastante antiga e especialistas acreditam que um "último ancestral eucarioto comum" (estudos topográficos permitiram a reconstrução conceitual desse organismo) já possuía a maquinaria básica do sistema de endomembranas, constituído por retículo 
endoplasmático, complexo de Golgi, endossomos e lisossomos. Ao nível molecular a situação encontrada é semelhante e esse organismo já possuía todas as famílias de proteínas definidas como críticas para os processos de tráfego, incluindo as RAB GTPases. Esses dados sugerem que a biossíntese e exocitose de moléculas nesse "último ancestral eucarioto comum" era de uma complexidade semelhante ao que observamos em "células modernas" (81).

Análises genômicas revelaram que a família das RABs é composta por 11 membros em Saccharomyces cerevisiae, sete membros em Schizosaccharomyces pombe, 29 membros tanto em Caenorhabditis elegans quanto em Drosophila melanogaster, 57 membros na angiosperma $A$. thaliana e mais de 70 em humanos (82). Entretanto, a complexidade dessa família pode ser ainda maior, visto que existem evidências de splicing alternativo em genes das RABs, que resultariam na produção de distintas isoformas funcionais (83).

Uma explicação para a expansão dessa família remete novamente ao passado, em que sucessivos eventos de duplicação gênica levaram ao surgimento de genes parálogos (genes derivados de um ancestral comum via duplicação gênica), acompanhados de mudanças relevantes em estruturas celulares. Alguns autores consideram que duplicações gênicas coordenadas de componentes da maquinaria de tráfego de vesículas centralizados nas RABs foram pré-requisito para diversificação de identidades vesiculares (84). Essa pode ser, porém, uma visão muito pretensiosa acerca do papel dessas proteínas, uma vez que a evolução de algumas estruturas celulares pode ter sido dirigida por alterações em outros genes, e as RABs podem ter sido somente posteriormente recrutadas para ocupar suas posições.

Em 1987, Salminem e Novick reportaram em um estudo seminal a descoberta de uma proteína RAS GTPase essencial para a liberação de vesículas em leveduras, a SEC4. Neste estudo, os pesquisadores observaram que mutações na SEC4 causavam a acumulação de vesículas derivadas do TGN, que eram destinadas à membrana plasmática, evidenciando que essa proteína desempenha um papel essencial no controle do estágio tardio da via secretória (85). No ano seguinte, outra proteína dessa família, a Ypt1, bem como seu homólogo em mamíferos, foram descritos como necessários para o transporte entre o retículo endoplasmático e o complexo de Golgi (86). Nessa mesma época outro grupo 
procurava por novos membros da superfamília ras, e após uma série de estudos utilizando sondas para fazer screening de uma biblioteca de cDNA de cérebro de rato, esse grupo isolou quatro genes que codificavam proteínas homologas a proteína YPT de leveduras, e nomearam esses genes de rab1, rab2, rab3 e rab4 (87 e 88).

Em menos de cinco anos após a descoberta dessa família de proteínas, mais de 20 membros haviam sido descritos e hoje, centenas deles, nas mais diversas formas de vida, desempenham diferentes papéis coordenando distintas vias de tráfego intracelular e sua importância vem aumentando a cada dia com as recentes descobertas que tem sido feitas acerca de suas funções (figura 6), tendo já sido implicadas em processos como regulação da transdução de sinais e de processos celulares como diferenciação, proliferação, agregação nuclear, remodelação do citoesqueleto (89), bem como diferentes patologias. Se pesquisado na timeline do Pubmed são encontrados em média 300 artigos publicados por ano com o tema RAB GTPase nos últimos cinco anos. 


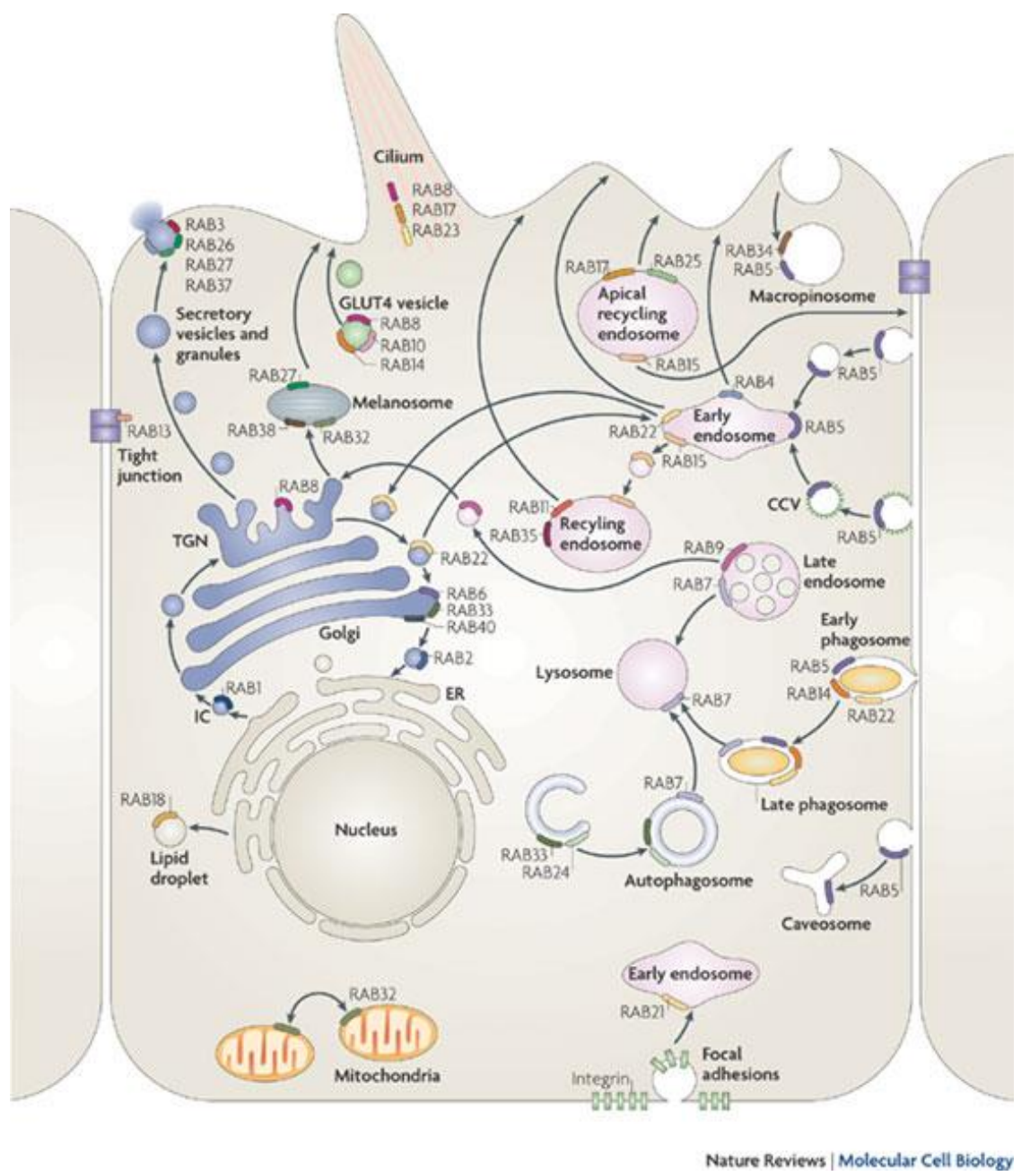

Figura 6 -Localização celular e função das RABs GTPases. Na figura podem ser observadas diferentes RABs em diferentes sítios exercendo as mais diversas funções. Fonte: Stenmark H.(2009)

As proteínas RABs constituem a maior família das small Ras-like GTPases e suas estruturas possuem em comum um domínio GTPase, sendo ainda compostas por seis lâminas $\beta$-pregueadas flanqueadas por cinco $\alpha$-hélices. A estrutura básica das RABs pode ser entendida observando-se a molécula de H-RAS, a primeira dessa família que foi cristalografada (figura 7). As proteínas da família RAB possuem cinco motivos de sequências conservadas conhecidas como "motivos da família RAB" envolvidos na ligação de nucleotídeos (G1-G5). Essas regiões parecem ser as responsáveis para que as interações com outras moléculas se dêem de forma específica. De maneira resumida, a região G1 ou alça-P (P-loop) está envolvida em uma série de interações estruturais com os fosfatos dos nucleotídeos. G2 é conhecida como alça de troca I (switch I loop), enquanto G3 é a região de troca II. Estas duas últimas regiões são os locais onde ocorre a hidrólise do GTP e, portanto, participam dos processos energéticos. Por fim, as regiões G4 e G5 estão envolvidas em 
interações com a base guanina e são responsáveis pela discriminação de outros nucleotídeos como os da molécula de ATP/ADP (90).

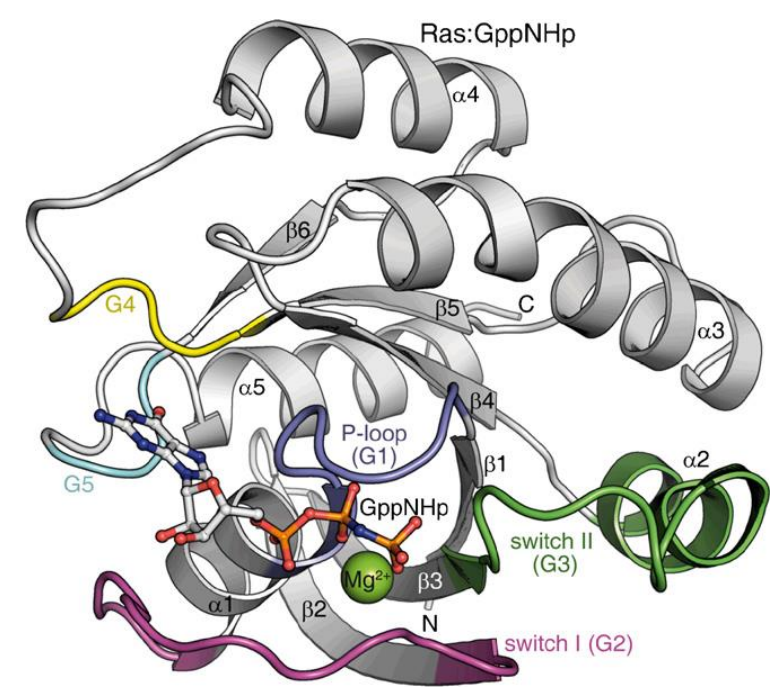

Figura 7 - Figura esquemática da estrutura tridimensional do H-Ras complexado a um análogo de GTP (GppNHp). Membros da família RAB, ARF e RHO GTPase possuem esta mesma estrutura básica. G1 refere-se à região alça-P, G2 é a região de troca I e G3 é a região de troca II. As regiões G4 e G5 participam do reconhecimento da guanina. Fonte: Itzen A. et al., (2011) (90).

Outra informação importante está relacionada a diferenças entre os membros dessa família. As regiões de troca das RABs são as únicas regiões dessas proteínas que sofrem mudanças conformacionais dependendo do status da RAB. A região de troca I e a região de troca II, bem como a região entre elas (interswitch region) formam o arcabouço básico em que acontecem as interações entre as RABs e seus efetores. Embora essas três estruturas sejam bastante conservadas, existem ali diferenças que permitem distinguir os membros dessa família (91).

O COOH-terminal do domínio GTPase é a região hipervariável das RABs, composta por 35-40 aminoácidos, e como o próprio nome já diz, é a porção das RABs que apresenta maior diferença dentre os variados grupos filogenéticos. Essa região é importante porque determina a localização subcelular das RABs em membranas específicas por meio de modificações pós-traducionais como a transferência de grupamentos hidrofóbicos geranilgeranil a um ou dois resíduos de cisteína dessa região. É importante ressaltar que essas modificações são irreversíveis quando comparadas com outras prenilações, que são facilmente reversíveis e que ocorrem em outros membros da família small Ras-like GTPases. A importância desse domínio foi demonstrada por uma série de experimentos elegantes nos quais os cientistas substituíram o domínio C-terminal da RAB7 pela mesma região da RAB5 e 
observaram a dinâmica das proteínas quiméricas. Como resultado, observou-se que o domínio C-terminal da RAB7 era suficiente para mobilizar a RAB5 quimérica para endossomos que continham RAB7 (92).

As RABs funcionam como interruptores moleculares, que alternam entre os estados "inativo" (ligado ao GDP), e "ativo" (ligado ao GTP), podendo com isso ativar e/ou desativar diferentes processos celulares (93). O ciclo das proteínas RABs é assegurado por um grande número de proteínas acessórias, entre as quais podemos incluir as REPs (do inglês, RAB escort proteins), que formam um complexo com as RABs recém sintetizadas, facilitando o encontro delas com geranilgeranil transferases, para a realização de mudanças póstraducionais. Quando a RAB está devidamente associada a sua membrana alvo, outra proteína acessória é necessária para que ocorra a troca do GDP pelo GTP, e esse papel é desempenhado pelas GEFs (do inglês, guanine-nucleotide exchange factors), que reconhecem resíduos específicos nas regiões de troca I e II, facilitando a liberação do GDP. As altas concentrações de GTP citosólico garantem que o GTP se ligue assim que o GDP é liberado (94).

Uma vez ligadas ao GTP, as RABs assumem sua conformação ativa, permitindo a interação com outras moléculas efetoras que incluem quinases, proteínas motoras e outros complexos, podendo assim desempenhar suas funções biológicas. Esses eventos terminam com a hidrólise do GTP, processo estimulado pelas GAPs (GTPase activating proteins) que fazem com que as RABs voltem ao seu estado inativo. Uma vez na conformação inativa, essas proteínas tornam-se alvos das chaperonas GDIs (do inglês, guanine nucleotide dissociation inhibitor), que são capazes de extraí-las das membranas em que estão inseridas e estabilizar as RABs ligadas ao GDP no citosol enquanto essas aguardam por novos rounds de inserção (Figura 8) (95). 


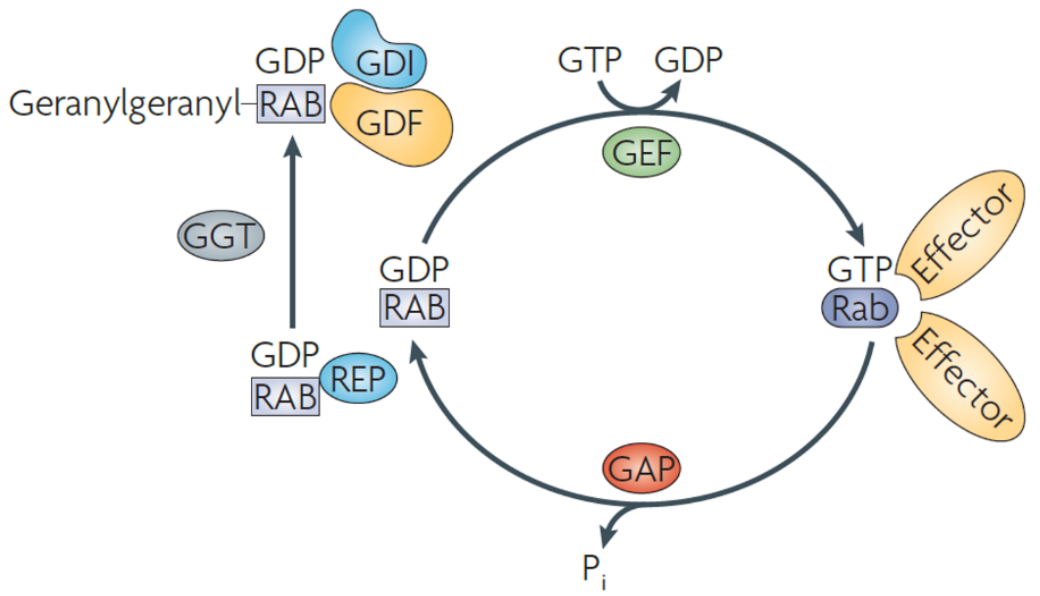

Figura 8 - Circuito de ativação e desativação das RAB GTPases. A conversão da RAB no estado inativo para o estado ativo ocorre com a troca do GDP por GTP, que é catalisada pelo GEF. A RAB na conformação ativa é reconhecida por proteínas efetoras e ocorre a conversão para o estado inativo por meio da hidrólise do GTP, estimulada pela GAP, liberando um fosfato inorgânico. Fonte: Stenmark H. (2011)

Após levantamento bibliográfico, diferentes funções associadas à RAB2 foram identificadas. A maior parte dos estudos, porém, relaciona de alguma maneira a RAB2 ao complexo de Golgi, sendo que nenhum outro estudo descreveu ainda qualquer função da RAB2 em grânulos citotóxicos, embora alguns estudos de proteômica tenham encontrado essa mesma proteína nessas organelas de células NK e linfócitos T CD8 humanos (96).

Estudos do início da década de 90 demonstraram que a RAB2 estava presente em uma região intermediária entre o retículo endoplasmático e o complexo de Golgi e associaram a presença dessa proteína a algum papel desenvolvido por ela na via exocítica. Esse mesmo estudo revelou também a presença da RAB5 e da RAB7 na membrana de endossomos, fornecendo evidências de que membros da família RAB estavam localizados em compartimentos específicos nas células de mamíferos. Este estudo, porém, foi realizado utilizando linhagens celulares de rins de roedores (97 e 98).

Embora aparentemente algumas RABs pareçam ter funções conservadas, outras possuem funções que dependem do tecido em que elas estão presentes, do tipo celular e até mesmo dos modelos estudados. Parece ainda que um grande número de RABs possui funções redundantes, enquanto que a função de muitas outras RABs permanece desconhecida. Por esses motivos é tão difícil fazer qualquer análise comparativa entre os membros dessa família (99). 
Um interessante estudo observou o aumento da expressão de RAB2 em PBMC de pacientes com câncer portadores de tumores sólidos. Esse estudo, porém, não conseguiu identificar nenhuma correlação entre o aumento da expressão de RAB2 e a contagem de monócitos e linfócitos ou com o tipo do tratamento desses pacientes. Embora ainda seja desconhecido o aumento da expressão dessa proteína, esse estudo forneceu evidencias de que a RAB2 possa estar envolvida em respostas imunes associadas a doenças neoplásicas (100). Outros estudos têm demonstrado que a RAB2A parece estar diretamente associada a um grande número de cânceres e em um desses estudos os pesquisadores propõe inclusive que a RAB2A seja utilizada como um marcador no diagnóstico e prognóstico para o câncer cervical escamoso, a segunda neoplasia maligna mais abundante em mulheres (101).

Embora a RAB2 tenha sido descoberta antes que a RAB5, é impressionante o número de estudos com essa última. São encontrados relatos na literatura associando a RAB5A ao tráfego de receptores (102); associada à produção de hormônios (103); à sinalização em neurônios (104); ao processo de transformação maligna (105) e até mesmo patógenos tem feito uso dessa maquinaria em favor de sua sobrevivência (106).

Apesar de inúmeras funções descritas para a RAB5 nos mais distintos tipos celulares, existe um consenso entre especialistas da área de que a RAB5 é a peça central por trás da regulação da via endocítica, fato que foi demonstrado tanto in vitro quanto in vivo (107).

A RAB17 é ainda menos estudada que todas as outras citadas anteriormente. Alguns estudos identificaram esta proteína fazendo parte de um sistema de transporte especializado em células epiteliais com a participação de endossomos (108 e 109), quando se acreditava que esta proteína era exclusiva de células epiteliais. Esses, porém, foram estudos isolados de um mesmo grupo e somente recentemente outro grupo identificou a RAB17 como parte da maquinaria secretória de melanócitos (110). A função desta RAB permanece ainda desconhecida e a literatura apresenta um déficit de informações sobre suas funções.

Um grande número de estudos determinou que a RAB18 é importante para a estrutura do retículo endoplasmático e para a via de transporte Golgi-retículo (111), sendo esta a sua função mais estudada até o momento. Defeitos nesta RAB já foram associados a 
uma síndrome conhecida como síndrome de Warburg micro, caracterizada por defeitos no desenvolvimento do olho e cérebro humano, bem como neurodegeneração (112).

O mal funcionamento das RABs e de outros membros das vias de tráfego intracelular está associado a uma série de doenças em humanos, bem como o câncer. Além disso, patógenos podem utilizar essas vias como forma de invadir e sobreviver nas células, e, por fim, um grande número de doenças e síndromes já foi descrito envolvendo defeitos em uma ou mais etapas dos processos de tráfego intracelular, podendo ser ainda mais graves quando afetam componentes do sistema imune.

\subsection{Doenças Associadas A Defeitos Nas Vias De Tráfego Intracelular}

A síndrome de Chediak-Higashi (CHS) é uma condição autossômica recessiva rara em que a função das células NK está prejudicada. Essa síndrome é caracterizada por infecções bacterianas frequentes, albinismo parcial e grânulos intracelulares gigantes em leucócitos e outros tipos celulares. São recorrentes as infecções causadas por Staphylococcus aureus, Streptococcus, organismos gram negativos, Candida, e Aspergillus. A produção de anticorpos e a fagocitose permanecem intactas, no entanto, os leucócitos apresentam migração prejudicada e são comuns episódios de neutropenia. Além disso, a função das plaquetas está prejudicada e os linfócitos do sangue periférico apresentam diminuição da citotoxicidade celular dependente de anticorpos (ADCC) para células tumorais (113).

Casos de linfohistiocitose ocorrem em aproximadamente $85 \%$ dos pacientes com CHS. Esse quadro é fatal e caracterizado por proliferação descontrolada de linfócitos, que cria uma condição semelhante a linfoma, com febre, anemia, neutropenia, hepatoesplenomegalia, linfadenopatia, infiltração de linfócitos no sistema nervoso central e trombocitopenia em alguns casos. Além desses sintomas, existem muitos outros descritos em pacientes portadores dessa condição como, por exemplo, problemas neurológicos naqueles pacientes que chegam à idade adulta.

Essas complicações são causadas por defeitos no gene CHS1, que codifica uma proteína citosólica de 428 kDa também chamada de CHS1, cuja função biológica permanece desconhecida. Nas células NK e linfócitos T CD8 desses pacientes (bem como em seu modelo animal - beige mouse), os grânulos se polarizam até a sinapse imunológica, entretanto, eles 
não conseguem se fundir com a membrana da célula. Os lisossomos em todas as células, incluindo os grânulos citotóxicos, possuem tamanho aberrante, sugerindo que a proteína CHS1 pode estar envolvida com a regulação dos eventos de fusão de membranas (114).

A síndrome de Hermansky-Pudlak (HPS) é um grupo de doenças genéticas que associa albinismo parcial e distúrbios hemorrágicos. A hipopigmentação da pele, cabelos e olhos é resultado da formação, do tráfego ou da transferência deficiente dos melanossomos para os queratinócitos, diferente do albinismo clássico, que é causado por deficiências em proteínas dos melanossomos como tirosinase, proteína P ou TYRP1. Defeitos hemorrágicos são devidos a agregação plaquetária deficiente (115).

Mutações em oito genes humanos e 16 genes em murinos têm sido relacionadas com essa síndrome. A doença é reconhecida como um conjunto geneticamente heterogêneo de condições autossômicas recessivas relacionadas em sua maioria a defeitos nos processos de tráfego intracelular. A HPS-2, por exemplo, é causada por mutações no gene que codifica a subunidade $\beta$ da proteína adaptadora AP3 dos lisossomos. A AP3 reconhece e encaminha proteínas com sinais de sorting baseados em tirosina (como LAMPs e TYR) para as organelas relacionadas aos lisossomos. Nos portadores da HPS-2, a deficiência da proteína AP3 prejudica a capacidade das células T CD8 em eliminar seus alvos. Os grânulos citotóxicos dos linfócitos T CD8 dos portadores HPS-2 falham em polarizar na direção da sinapse imunológica, possivelmente, porque a AP3 seja necessária em algum momento para o movimento desses grânulos (116).

A síndrome de Griscelli (GS) é uma doença autossômica recessiva causada por mutações nos genes da miosina V5 MYO5A (GS1), RAB27A (GS2) ou melanofilina MLPH (GS3). As três mutações apresentam um fenótipo semelhante, caracterizado primariamente pelo tráfego de vesículas deficiente. Os portadores da GS apresentam diluição da pigmentação da pele e dos cabelos e presença de grandes aglomerados de pigmento nos fios de cabelo, bem como acumulação de melanossomos maduros nos melanócitos, acompanhados por uma atividade indiscriminada de linfócitos T e macrófagos, conhecida como síndrome hemofagocítica (117 e 118).

Mutações recorrentes na RAB27A são do tiposem sentido homozigotas ou mutações na mudança do quadro de leitura, com apenas poucos relatos de casos de mutações de 
sentido alterado. Uma mutação de sentido alterado resulta em uma proteína não funcional ou perda completa da proteína, acarretando distúrbios na estabilidade do mRNA ou da proteína, diminuindo, consequentemente, a quantidade celular disponível de RAB27A. Se a mutação resulta na junção prematura de motivos de geranilgeranilação C-terminal, a RAB27A não pode ser direcionada à vesícula correta, resultando em perda de funcionalidade (119).

Diversas evidências têm também associado alterações nas RABs, além de suas proteínas efetoras, com o câncer em humanos. Em uma série de estudos de genômica comparativa, Mills e colaboradores avaliaram os níveis de expressão do mRNA da RAB25 em amostras de pacientes com câncer de ovário e câncer de pulmão. No estudo em questão, os níveis de expressão do mRNA dessa proteína em amostras de câncer de ovário estavam elevados em $80 \%$, quando comparados com tecidos normais, e observou-se um aumento de 67\% na expressão do mRNA da RAB25 em amostras de pacientes com câncer de pulmão comparados com amostras de tecido pulmonar sadio (120).

Alterações em outras RABs como a RAB5, RAB7, RAB11 também têm sido relacionadas ao câncer. Além disso, defeitos na RAB1 e RAB7 têm sido associados a disfunções neuronais; anormalidades na RAB8 podem causar degeneração da retina, e deficiências na RAB27A e RAB38 podem ocasionar distúrbios na pigmentação e no sistema imune (121).

Recentes avanços na área da imunologia e biologia celular forneceramvaliosas informações na forma com que as células citotóxicas eliminam seus alvos, e o estudo de imunodeficiências raras tem sido de imenso valor não apenas em decifrar as moléculas envolvidas na exocitose de grânulos mas também ilustrando o papel da via dos grânulos na homeostase imunológica (122), embora as ferramentas de biologia celular para o silenciamento gênico em células NK ainda sejam pouco eficientes. A importância patofisiológica das proteínas que participam da dinâmica das organelas relacionadas aos lisossomos, garantindo seu funcionamento perfeito, é facilmente percebida analisando a severidade das doenças associadas a defeitos nessas vias.

Com base nas informações presentes neste texto, dados na literatura sobre o papel das RABs no tráfico intracelular, carência de dados na literatura sobre a via dos grânulos 
citotóxicos e resultados prévios do nosso grupo, nosso objetivo neste trabalho foi confirmar a presença das proteínas RAB2A, RAB5A, RAB17 e RAB18 em grânulos citotóxicos de células NK de uma linhagem celular humana, desenvolver uma metodologia para o silenciamento gênico da proteína RAB2A humana e desenvolver ferramentas simples e de baixo custo para o estudo de funções celularesassociadas a biologia dos grânulos citotóxicos. 


\section{MATERIAIS E MÉTODOS}

\subsection{Camundongos}

Neste trabalho foram utilizados camundongos isogênicos C57BL/6 machos adultos, pesando entre 25-30 g, com idade entre 3-8 semanas provenientes do Biotério de Experimentação do Departamento de Imunologia do Instituto de Ciências Biomédicas da Universidade de São Paulo. Os animais foram mantidos até o sacrifício em estantes ventiladas com água e ração ad libitum, em condições SPF em um espaço reservado para eles no Biotério de Experimentação. Este projeto foi aprovado pela Comissão de Ética no Uso de Animais (CEUA) do ICB/USP sob o número 158/11 e uma cópia da aprovação do Comitê de Ética, bem como da renovação do mesmo, foram anexadas nesta tese. Todos os experimentos utilizando animais foram realizados obedecendo rigorosamente os Princípios Éticos na Experimentação Animal.

\subsection{Linhagens Celulares}

RAJI - linhagem de linfócito B, derivada de linfoma de Burkitt, gentilmente cedida pelo Dr. Douglas Green (St Jude's Children Hospital, Memphis, EUA);

YT - Linhagem celular estabelecida a partir do fluído pericardial de um paciente do sexo masculino com idade de 15 anos com leucemia linfoblástica aguda durante a recidiva (acompanhada de timoma) em 1983. As células exibem características típicas de células NK e análises de PCR demonstraram positividade para EBV. As células possuem uma morfologia arredondada, crescendo sozinhas ou em grumos, sendo mantidas em meio de cultura RPMI com $10 \%$ SFB sem a necessidade da adição de IL-2. Análises de citometria de fluxo caracterizaram essas células como sendo células $\mathrm{CD2}^{-}, \mathrm{CD}^{-}, \mathrm{CD}^{-}, \mathrm{CD}^{-}, \mathrm{CD}^{-}, \mathrm{CD}^{+}, \mathrm{CD}^{-}$, $\mathrm{CD}^{-}{ }^{-}, \mathrm{CD}^{-}, \mathrm{CD}^{+} 5^{+} \mathrm{CD}^{+} 0^{+}, \mathrm{CD}^{-} 4^{-}, \mathrm{TCR}^{-}$alpha/beta-, TCRgamma/delta ${ }^{-}$(Informações retiradas do Banco de Células e Microrganismos Alemão http://www.dsmz.de). Linhagem gentilmente cedida pelo Dr. Seamus Martin (Trinity College, Dublin, Irlanda). 


\subsection{Condições Gerais de Cultivo Celular}

As células YT e RAJI foram cultivadas em meio de cultura RPMI-1640 (Thermo Fisher, Waltham, MA, EUA) suplementado com 10\% de soro fetal bovino (Thermo Fisher), 2 mM de L-glutamina (Sigma-Aldrich, MO, EUA), antibióticos penicilina (100 $\mu \mathrm{g} / \mathrm{ml})$ (Thermo Fisher) e estreptomicina $(100 \mu \mathrm{g} / \mathrm{ml})$ (Thermo Fisher) e mantidas em placas de seis poços em incubadoras a $37{ }^{\circ} \mathrm{C}$ com $5 \%$ de $\mathrm{CO}_{2}$. Repiques eram realizados a cada dois dias ou quando necessário.

Para as células primárias derivadas de camundongos utilizamos RPMI-1640 (Thermo Fisher) suplementado com $10 \%$ de soro fetal bovino (Thermo Fisher), 2 mM de L-glutamina (Sigma Aldrich) antibióticos penicilina $(100 \mu \mathrm{g} / \mathrm{ml})$ (Thermo Fisher) e estreptomicina (100 $\mu \mathrm{g} / \mathrm{ml}$ ) (Thermo Fisher), 0,5 mg/ml de gentamicina (Thermo Fisher), 1\% aminoácidos não essenciais MEM NEAA (Thermo Fisher), 1\% solução de vitaminas (Thermo Fisher), 1 mM de piruvato de sódio (Thermo Fisher) e 0,055 mM de 2-Mercaptoetanol (Thermo Fisher) e 20 $\mathrm{ng} / \mathrm{mL}$ de IL-2 recombinante humana. As células eram mantidas em placas de 12 poços a 37 ${ }^{\circ} \mathrm{C}$ com $5 \%$ de $\mathrm{CO}_{2}$ e repiques eram realizados a cada dois ou três dias.

O uso das células em todos os experimentos foi condicionado a uma viabilidade mínima de 95\% das células, verificada por meio de coloração com azul de Trypan 0,2\% e contagem em câmara de Neubauer.

\subsection{Protocolo de imunofluorescência para microscopia confocal}

Este protocolo foi utilizado na padronização dos anticorpos e também para a geração das imagens finais apresentadas nesta tese. A primeira etapa consistiu na preparação de uma lâmina de 10 poços de $6 \mathrm{~mm}$ de diâmetro revestidos com teflon (Electron Microscopy (EM) Reagents) com $50 \mu \mathrm{l}$ poli-L-lisina (Sigma Aldrich) em cada poço e incubada em estufa à $37{ }^{\circ} \mathrm{C}$ por 30 minutos. Após esse período, a poli-L-lisina foi removida e as lâminas foram deixadas por 15-20 minutos no fluxo laminar para secagem. Em seguida, 1 × $10^{6}$ células YT foram ressuspendidas em $1 \mathrm{ml}$ de RPMI-1640 com 10\% SFB e $50 \mu \mathrm{l}$ dessa suspensão contendo aproximadamente $5 \times 10^{4}$ células foram adicionados em cada poço e incubados por 1 hora em estufa à $37{ }^{\circ} \mathrm{C}$ para adesão das células. Terminado o período de incubação, o sobrenadante foi aspirado e foram aplicados $50 \mu \mathrm{L}$ de paraformaldeído a $2 \%$ em cada poço e 
incubados por 30 minutos em estufa à $37^{\circ} \mathrm{C}$. Em seguida, a lâmina foi lavada três vezes com PBS e foi aplicado $20 \mu \mathrm{L}$ de TritonX-100 0,1\% em cada poço por 5 minutos à temperatura ambiente. Novamente a lâmina foi lavada por três vezes com PBS. Em seguida foi feito o bloqueio com BSA $1 \%$ diluído em PBS por no mínimo uma hora em estufa à $37^{\circ} \mathrm{C}$. O passo seguinte foi a aplicação dos anticorpos primários nas concentrações previamente determinadas (LAMP-1 (ab25630, Abcam, Cambridge, UK), LAMP-2 (ab25631, Abcam), granzima B (ab10912, Abcam), perforina (AB47224, Abcam), tubulina (SC-5286, Santa Cruz Biotechology, Dallas, Texas, EUA), Faloidina (68825, Sigma Aldrich), RAB2A (SC-26547, Santa Cruz Biotechnology), RAB5A (ab109534, Abcam), RAB17 (ab77437 Abcam) e RAB18 (SAB 4200173 , Sigma Aldrich) que reagiram por 30 minutos a $37^{\circ} \mathrm{C}$. Novamente três lavagens com PBS foram realizadas e então foi aplicado o anticorpo secundário (AlexaFluor 488 (A11055) e 546 (A11056) - Invitrogen, Carlsbad, Califórnia, EUA), reagindo por 30 minutos. Mais três lavagens com PBS foram realizadas e, então, realizamos a marcação do núcleo com o corante vital Hoechst (Sigma Aldrich) diluído 1:100 e deixado reagir por 30 minutos em estufa à $37^{\circ} \mathrm{C}$. Mais três lavagens com PBS foram realizadas e a lâmina foi deixada no fluxo laminar por 15-20 minutos para secagem. A lâmina foi montada com uma gota por poço de SlowFade (Thermo Fisher) à temperatura ambiente e uma lamínula foi adicionada sobre a lâmina e vedada com esmalte incolor. As lâminas foram mantidas em câmara úmida escura sob refrigeração até a realização das imagens. As imagens de microscopia confocal de varredura à laser foram realizadas no microscópio confocal Zeiss LSM 510 na Central Analítica do Instituto de Química e no microscópio confocal multifótonsZeiss LSM-780 NLO, do CEFAP da Universidade de São Paulo. Foi utilizada a objetiva C-Apochromat de $40 \mathrm{X}$ e 63 $X$, no espectro de $364 \mathrm{~nm}, 488 \mathrm{~nm}, 590 \mathrm{~nm}$ e 633nm. As imagens foram analisadas no software ImageJ do National Institute of Health. Todas as análises foram realizadas no mínimo em triplicata e em todos os experimentos foram incluídos controles dos anticorpos secundários, assegurando que o sinal capturado não fosse devido a algum tipo de marcação inespecífica dos anticorpos secundários.

2.5 Protocolo de imunohistoquímica para microscopia eletrônica de transmissão

Células YT foram centrifugadas a $90 \mathrm{~g}$ por 5 minutos. Os sobrenadantes foram descartados e os pellets ressuspendidos em paraformaldeído $2 \%$ e permaneceram nesse 
fixador por dois dias. As células foram então lavadas por cinco minutos em $\mathrm{H}_{2} \mathrm{O}$ destilada à temperatura ambiente e 15 minutos em TBS pH 7,24 mais glicina 0,02 M também em temperatura ambiente. Foi feito o bloqueio utilizando uma solução de TBS+BSA3\%+NaN 0,05\%+Tween 20 0,1\% Ph 7,2 durante 30 minutos. Após essa etapa, as telas foram incubadas em câmara úmida com anticorpo primário RAB2A (SC-26547, Santa Cruz Biotechnology OU SAB2500850, Sigma Aldrich) nas diluições 1:10 e 1:50 em solução de TBS + BSA 0,1\% + $\mathrm{NaN}_{3}$ $0,05 \%$ + Tween20 0,1\% pH 7,3 overnight a $4{ }^{\circ} \mathrm{C}$ em geladeira. No dia seguinte foram realizadas cinco lavagens de cinco minutos cada uma com TBS + BSA 0,1\% + $\mathrm{NaN}_{3} 0,05 \%+$ Tween20 0,1\% pH 7,3, e uma lavagem de cinco minutos com TBS + BSA 0,1\% + $\mathrm{NaN}_{3}$ 0,05\% + Tween20 0,1\% pH 8,2. Foi realizada incubação com anticorpo secundário anti-lgG de cabra conjugado com ouro coloidal 18 nm (705-215-145, Jackson ImmunoResearch, West Grove, PA, EUA) na diluição 1:10 em solução de $\mathrm{NaCl}$ 0,5 M + BSA 0,1\% + SFB 5\% + Tween20 0,05\% $\mathrm{pH} 8,0$, por duas horas à temperatura ambiente. Em seguida, foi realizada uma lavagem de cinco minutos em TBS + BSA $1 \%+\mathrm{NaN}_{3} 0,05 \%$ + Tween20 0,1\% pH 8,2, três lavagens de cinco minutos em TBS + BSA 0,1\% + $\mathrm{NaN}_{3} 0,05 \%+$ Tween $200,1 \%$ pH 7,3 e duas lavagens de cinco minutos em TBS + Tween20 0,1\% pH 7,3 à temperatura ambiente. Para fixação, as telas foram incubadas por 10 minutos em glutaraldeído 2,5\% em tampão cacodilato de sódio $0,1 \mathrm{M} \mathrm{pH} 7,2$, seguido por três lavagens de dois minutos com água destilada. As telas foram deixadas secando em papel filtro protegidas da poeira em uma placa de Petri. As telasforam examinadas usando um microscópio eletrônico de transmissão JEOL 100 CX II 100 KW (aumentos de 6000 X, 20000 X e 50000 X) no Instituto de Ciências Biomédicas da Universidade de São Paulo.

\subsection{Geração de blastos de linfócitos T CD8}

Para a realização deste experimento, baços de camundongos machos adultos C57BI/6 selvagens foram removidos e colocados em poços de placas de cultura de seis poços estéreis contendo dois $\mathrm{ml}$ de meio de cultura RPMI vitaminado. Os baços foram em seguida delicadamente macerados com o auxílio do êmbolo de uma seringa estéril a fim de se obter uma suspensão celular homogênea. Esta suspensão foi transferida para tubos plásticos de 15 $\mathrm{ml}$ e colocada no gelo por cerca de cinco minutos. Após este período, a cápsula e fragmentos maiores do baço precipitaram e o sobrenadante foi transferido para um novo tubo. $O$ tubo 
contendo os esplenócitos livres da cápsula foi então centrifugado a 500 g por cinco minutos a $4{ }^{\circ} \mathrm{C}$. Após a centrifugação, o pellet estava vermelho devido a uma grande quantidade de hemácias. O pellet foi ressuspendido e adicionamos $2 \mathrm{ml} /$ baço de uma solução para lisar hemácias (ACK) e deixamos por dois minutos em temperatura ambiente, agitando delicadamente o tubo. Após os dois minutos adicionamos meio de cultura à suspensão celular, a fim de bloquear a reação de lise e centrifugamos novamente. Após esta centrifugação o pellet estava branco. Ressuspendemos o pellet em um volume de meio de cultura para contagem (separamos em um microtubo $100 \mu \mathrm{L}$ da suspensão celular e fixamos com $100 \mu \mathrm{L}$ de paraformaldeído $1 \%$ para fenotipagem e análise por citometria de fluxo). Após a contagem das células, realizamos o ensaio de adesão para remoção de células aderentes como monócitos. Para este ensaio colocamos $3 \times 10^{7}$ células em uma placa de Petri de $10 \mathrm{ml}$, com o volume final de $10 \mathrm{ml}$ de meio de cultura e deixamos na estufa aderindo por duas horas. Após o período de adesão recolhemos o sobrenadante (população enriquecida de linfócitos) sem lavar a placa e passamos por uma coluna de lã de nylon para remoção de linfócitos B. Após passar pela coluna, centrifugamos a suspensão celular e realizamos uma nova contagem. Nesta etapa plaqueamos $6 \times 10^{6}$ células por poço em placas de cultura estéreis de 24 poços. Para enriquecer ainda mais a nossa população de interesse, adicionamos $200 \mu \mathrm{l}$ de soro total de camundongos selvagens (no qual se encontram proteínas do complemento) e $1 \mu \mathrm{g} / \mathrm{ml}$ de anticorpos anti-CD4. Com isso, induzimos a ativação da via clássica do complemento e, consequente morte das células que expressam a proteína CD4. Além disso, adicionamos Concanavalina A (ConA - um potente mitógeno conhecido por estimular células T) de maneira que fique uma concentração final nos poços de $5 \mu \mathrm{g} / \mathrm{ml}$. O volume final em cada poço foi de dois $\mathrm{ml}$. A seguir deixamos incubando na estufa a $37^{\circ} \mathrm{C}$ e $5 \% \mathrm{CO}_{2}$ por 48 horas. Após o período de incubação, recolhemos as células de todos os poços, centrifugamos e lavamos com meio fresco para a retirada da ConA. Replaqueamos novamente as células e adicionamos $250 \mathrm{U} / \mathrm{ml}$ de IL-2 (PeproTech, New Jersey, EUA). Deixamos incubando novamente na estufa por mais 48 horas. Após a segunda incubação adicionamos mais uma vez IL-2, mas sem lavar as células desta vez. Nessa etapa foi necessário expandir as células para mais uma placa. As células retornaram para a estufa para mais uma incubação de 96 horas e após esse período as células estavam prontas para serem utilizadas na realização do experimento (separamos em um microtubo $100 \mu \mathrm{L}$ da suspensão celular e fixamos com $100 \mu \mathrm{L}$ de paraformaldeído 1\%). 
2.7 Protocolo de separação celular por beads magnéticas

Este protocolo refere-se ao kit de separação EasySep ${ }^{\text {TM }}$ Mouse CD8+ T Cell Enrichment Kit (StemCell, Vancouver, CA). Foi preparada uma suspensão celular na concentração de $1 \times 10^{8}$ cels $/ \mathrm{ml}$ em meio recomendado (PBS + 2\% SFB com $1 \mathrm{mM}$ EDTA). As células foram colocadas em tubos de poliestireno de $5 \mathrm{ml}$ estéreis e foi adicionado o Normal rat serum (fornecido) na proporção de $50 \mu \mathrm{L} / \mathrm{ml}$ de células. Em seguida, adicionou-se o EasySepMouse CD8+ T Cell Enrichment Cocktail (fornecido) na proporção de $50 \mu \mathrm{L} / \mathrm{ml}$ de células e incubamos por 15 minutos em geladeira $\left(2-8{ }^{\circ} \mathrm{C}\right)$. $\mathrm{O}$ próximo passo foi a adição do EasySep Biotin Selection Cocktail 2 (fornecido) na proporção de $100 \mu \mathrm{L} / \mathrm{ml}$ de células, misturamos bem e incubamos por mais 15 minutos na geladeira. A seguir Adicionamos o EasySep D2 Magnetic Particles (fornecido) na proporção de $100 \mu \mathrm{L} / \mathrm{ml}$ de células, misturamos bem e incubamos por 5 minutos na geladeira $\left(2-8^{\circ} \mathrm{C}\right)$. $\mathrm{O}$ volume da suspensão celular foi corrigido para um volume total de $2.5 \mathrm{ml}$ adicionando o meio recomendado. Colocamos o tubo no magneto e deixamos descansando por 5 minutos. Pegamos o magneto e em um movimento contínuo invertemos o magneto e o tubo, despejando a fração desejada em um novo tubo de poliestireno de $5 \mathrm{ml}$. As células indesejadas marcadas magneticamente permaneceram dentro do tubo inicial, asseguradas pelo campo magnético do magneto, enquanto a fração enriquecida encontrava-se no novo tubo. A pureza dos linfócitos T CD8 foi avaliada por meio de citometria de fluxo.

\subsection{Ensaio de contato entre células alvo e efetoras}

Para realização deste ensaio utilizamos como células efetoras as células YT e como células alvo a linhagem celular RAJI. Neste ensaio colocamos um total de 1 × $10^{5}$ células em diferentes proporções de células alvo e efetoras que variaram de 1:2, 1:4, 1:6, 2:1, 4:1 e 6:1 na relação célula efetora/célula alvo em placas de cultura estéreis de 96 poços contendo meio RPMI-1640 com $10 \%$ de soro fetal bovino e incubamos a $37{ }^{\circ} \mathrm{C}$ e $5 \% \mathrm{CO}_{2}$ em estufa por até 240 minutos, avaliando períodos de 15 em 15 minutos. A cada período as células eram recolhidas e submetidas a uma técnica chamada Cytospin, uma forma rápida e simples que utiliza os princípios da centrifugação para preparar amostras de células para microscopia. A citocentrífuga deposita a amostra de células em uma região delimitada de uma lâmina de vidro e permite a absorção do fluído residual pelo filtro que fica na câmara de amostra. As 
lâminas foram coradas com o kit INSTANT PROV (Newprov, PR, BR), um conjunto de corantes para coloração panóptica diferencial dos elementos do sangue e foi utilizado conforme as instruções do fabricante. Neste ensaio tentamos encontrar o intervalo de tempo com maior número de complexos célula efetora/célula alvo.

2.9 Protocolo de marcação de lisossomos com corante LysoTracker

Foram plaqueadas $5 \times 10^{5}$ células/poço num volume final de um $\mathrm{ml}$ de meio de cultura RPMI-1640 (conforme descrito acima) contendo 12,5 nM; 25 nM; 50 nM e 75nM do corante (L7528, Thermo Fischer), previamente diluídos em meio de cultura pré aquecido, e incubados por uma ou duas horas à $37^{\circ} \mathrm{C}$ e $5 \% \mathrm{CO}_{2}$. Ao final de cada tempo, cada poço foi coletado, lavado e fixado com PFA 1\% diluído em PBS. As amostras foram analisadas por citometria de fluxo no FACS Canto II (BD Bioscience, Nova Jersey, EUA) e analisamos com o software de análise FlowJo (Tree Star, Ashland, EUA) a média das intensidades de fluorescência em cada amostra.

\subsection{Ensaio para ativação de células NK e linfócitos T CD8}

Células YT foram colocadas em meio RPMI-1640 com 2\% de SFB por 24 horas antes do ensaio. Em seguida, 1 × $10^{6}$ células foram plaqueadas em poços de placas de 24 poços, em um volume final de $1 \mathrm{ml}$ de meio de cultura RPMI-1640 com diferentes estímulos já descritos na literatura em uma condição baixa de soro (utilizamos 2\%) e incubadas por 24 horas, $37^{\circ}$ e $5 \% \mathrm{CO}_{2}$. Como controle utilizamos um poço sem estímulo contendo apenas meio com $2 \%$ de SFB. A fim de ativar as células NK utilizamos diferentes estímulos e concentrações descritos na literatura, são eles IL-2 250 ng/ml(Peprotech, Rocky Hill, NJ, EUA), INF- $\alpha 1000 \mathrm{U} / \mathrm{ml}$ (Biosintética, SP, BR), PMA (100 ng/ml) /IONOMICINA (1 ug/ml) (Sigma Aldrich) e como estímulo negativo utilizamos meio sem soro e um meio com $50 \%$ de sobrenadante de uma linhagem tumoral de melanoma humana filtrado (SK-MEL-28). Ao final do período as células foram coletadas, marcadas com os respectivos anticorpos conforme protocolo descrito nesta seção, fixadas e analisadas por citometria de fluxo no FACS Canto II (BD Bioscience). 
Dentre os parâmetros avaliados neste ensaio, foram incluídos marcadores bem descritos na literatura que são expressos por células NK como CD25, CD40L, CD69, além da citocina INF- $\gamma$ e analisamos também a viabilidade celular com LIVE/DEAD.

2.11 Protocolo de transdução estável de células primárias não aderentes utilizando lentivírus portando shRNA

\subsubsection{Desenho do plasmídeo pLKO-shRNA-rab2a}

Os protocolos aqui descritos, bem como os experimentos realizados referentes a esta parte do trabalho foram realizados com a colaboração da Dra. Barbara Mello, Pós-Doc do laboratório de Biologia Celular e Molecular.

Para o silenciamento pós transcricional do gene rab2a foi construído um plasmídeo pLKO-shRNA-rab2a(figura 9). As sequências alvo e a sequência hairpin(5'-CCGGGCTCGAATGATAACTATTGAT-CTCGAG ATCAATAGTTATCATTCGAGC-TTTTT-3') que foi utilizada na construção do vetor está depositada no site RNAi consortium. As regiões escolhidas para o silenciamento, bem como os controles para o experimento podem ser vistos resumidos na Tabela 1. Esta sequência contém 21 nucleotídeos específicos para o gene alvo, uma região espaçadora (grampo) de sete nucleotídeos seguida de outros 21 pb correspondentes à sequência específica no sentido reverso complementar. Por fim, uma sequência de terminação (TTTTTT), localizada downstream aos 29 pb complementares à sequência específica, finaliza a transcrição feita pela RNA Pol III. A partir desta sequência foram desenhados os seguintes oligonucleotídeos: 


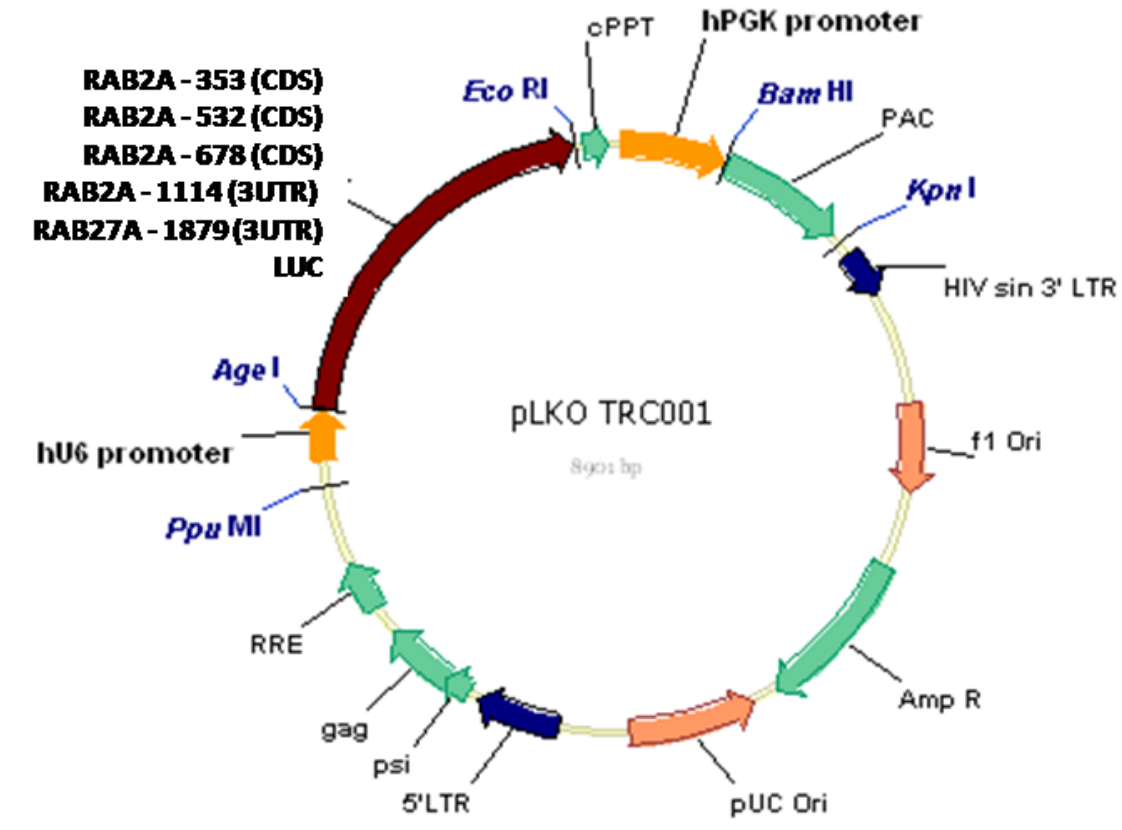

Figura 9 - Imagem representativa do plasmídeopLKO.1 contendo o marcador de seleção PAC (gene que confere resistência à Puromicina), os sítios de clivagem para as enzimas Eco RI e Age I e a região contendo os shRNA para RAB2A murina em diferentes sítios, RAB27A e para uma determinada região do gene da luciferase (Fonte: Adaptado de http://www.broadinstitute.org/rnai/public/vector/details?vector=pLKO.1).

Sequência senso:

5'-CCG-GGCTCGAATGATAACTATTGATCTCGAGATCAATAGTTATCATTCGAGCTTTTTG-3'

Sequência anti-senso:

R 5'-AATTCAAAAAGCTCGAATGATAACTATTGATCTCGAGATCAATAGTTATCATTCGAGC-3'

\begin{tabular}{|c|c|c|c|}
\hline Tipo do Constructo & Gene & Taxonomia & Posição \\
\hline shRNA & Rab2a & Murino & 353 (CDS) \\
\hline shRNA & Rab2a & Murino & 532 (CDS) \\
\hline shRNA & Rab2a & Murino & 678 (CDS) \\
\hline shRNA & Rab2a & Murino & 1114 (3UTR) \\
\hline shRNA & Rab27a & Murino & 1879 (3UTR) \\
\hline shRNA & LUC & Vagalume & - \\
\hline
\end{tabular}

Tabela 1 - Tabela contendo informações sobre os shRNA utilizados nos experimentos para o silenciamento gênico da RAB2A. 
Foram incluídos dois controles para a realização deste experimento, um shRNA contendo uma sequência específica para o gene RAB27, sabidamente envolvida nos processos de exocitose de grânulos citotóxicos; e outro shRNA contendo uma sequência para um gene irrelevante, ou seja, uma sequência que não está presente no camundongo. Para esta finalidade incluímos o gene da luciferase, presente apenas em vagalumes. Esse é um controle amplamente utilizado em experimentos deste tipo.

\subsubsection{Clonagem dos Oligos no Vetor pLKO.1}

A primeira etapa consistiu em anelar os oligos formando uma fita dupla, a qual foi inserida no vetor pLKO.1. A reação de anelamento foi feita nas seguintes condições: $30 \mu \mathrm{L}$ $\mathrm{H}_{2} \mathrm{O}$ miliq $+15 \mu \mathrm{L}$ primer senso $(100 \mathrm{mM})+15 \mu \mathrm{L}$ primer anti-senso $(100 \mathrm{mM})+15 \mu \mathrm{L}$ tampão de anelamento (50 mM Tris, $100 \mathrm{mM} \mathrm{NaCl}$ ). Em seguida a amostra foi incubada a 90 ${ }^{\circ} \mathrm{C}$ por um minuto e 60 minutos a $37{ }^{\circ} \mathrm{C}$. Para facilitar a ligação do inserto no vetor, o produto do anelamento dos oligos foi fosforilado. Para isso $5 \mu \mathrm{L}$ dos oligos anelados foram colocados em $12 \mu \mathrm{L}$ de $\mathrm{H}_{2} \mathrm{O}$ com $2 \mu \mathrm{L}$ de tampão T4 ligase (contendo $1 \mathrm{mM}$ ATP) e1 $\mu \mathrm{L}$ de T4 PNK (quinase). A amostra foi incubada por 40 minutos a $37{ }^{\circ} \mathrm{C}$ e por 10 minutos a $70{ }^{\circ} \mathrm{C}$ para inativar a T4 PNK.

Para a clonagem dos oligos no vetor pLKO.1, $5 \mu \mathrm{g}$ deste vetor foram digeridos simultaneamente com as enzimas EcoRI e Agel em tampão 1 (New EnglandBiolabs - NEB, Ipswich, MA, EUA) a $37{ }^{\circ} \mathrm{C}$ por duas horas. O produto da digestão foi analisado por eletroforese em gel de agarose de 1\% diluído em tampão TAE (40 mM Tris-acetato, $1 \mathrm{mM}$ EDTA, pH 8.0). A voltagem utilizada na corrida eletroforética foi de $90 \mathrm{~V} / \mathrm{cm}$ e o material correu por uma hora e 30 minutos. O produto de 1,9 kb foi purificado com o kit de extração de gel (Qiagen, Valencia, CA, EUA), conforme as instruções do fabricante. A reação de ligação foi realizada utilizando $3 \mu \mathrm{l}$ do produto dos oligos anelados e fosforilados com $50 \mathrm{ng}$ do vetor pLKO digerido conforme descrito acima. As amostras (vetor + inserto + água) foram incubadas a $65^{\circ} \mathrm{C}$ por 10 minutos e resfriadas em gelo por cinco minutos. Após esse período de incubação, foram adicionados quatro $\mu \mathrm{L}$ do tampão ligase $5 \times$ (Invitrogen) e $1 \mu \mathrm{L}$ de T4 DNA ligase (Invitrogen), sendo estes $20 \mu \mathrm{L}$ finais incubados por 16 horas a $14{ }^{\circ} \mathrm{C}$. 
Estas etapas foram desenvolvidas com a colaboração da Dra. Barbara Mello, no Memorial Sloan Kettering Cancer Center (Nova York, EUA), no laboratório do Dr. Scott Lowe e enviadas para o Brasil.

\subsubsection{Transformação Bacteriana com plasmídeo pLKO-shRNA-rab2a}

As próximas etapas foram desenvolvidas no Brasil, no Laboratório de Biologia Celular e Molecular

Dez microlitros do produto de ligação foram adicionados a $100 \mu \mathrm{l}$ de bactéria competente da linhagem DH10B e $100 \mu$ de TBF1 $\left(\mathrm{CH}_{3} \mathrm{COOK} 0,03 \mathrm{M}, \mathrm{MnCl}_{2} .4 \mathrm{H}_{2} \mathrm{O} 0.05 \mathrm{M}\right.$, $\mathrm{KCl} 0.1 \mathrm{M}, \mathrm{CaCl}_{2}, 2 \mathrm{H}_{2} \mathrm{O}$, glicerol $15 \%$ e água). Em seguida, a mistura (bactéria + produto de ligação + TBF1) foi incubada em gelo por 30 minutos. Ao final da incubação, a mistura permaneceu em temperatura ambiente por 10 minutos, e posteriormente, um $\mathrm{ml}$ de meio SOC (20 g triptona, $5 \mathrm{~g}$ de extrato de levedura, $0.5 \mathrm{~g}$ de $\mathrm{NaCl}, 20 \mathrm{mM}$ de glicose e água para um volume final de $1 \mathrm{~L}$ ) foi acrescentado. As bactérias foram incubadas por uma hora a 37 ${ }^{\circ} \mathrm{C}$. Ao término deste período, as bactérias foram centrifugadas a $400 \mathrm{~g}$ por 5 minutos e semeadas em meio LB ágar (Luria Broth, $10 \mathrm{~g}$ de peptona, cinco g de extrato de levedura, 10 g de $\mathrm{NaCl}, 2.25$ \% de ágar e água para um volume final de 1 L) contendo o antibiótico referente ao gene de resistência do plasmídeo, no caso, Ampicilina (A0166 - Sigma, MO, USA), e incubadas overnight em estufa $37^{\circ} \mathrm{C}$.

\subsubsection{Mini Preparação Plasmidial}

As colônias de bactérias transformadas foram inoculadas em cinco $\mathrm{ml}$ de meio LB contendo antibiótico e incubadas a $37^{\circ} \mathrm{C}$ sob agitação de $180 \mathrm{rpm}$ durante 16 horas. Um mililitro e meio de suspensão bacteriana foi transferido para um tubo Eppendorf e centrifugado a $6.800 \mathrm{~g}$ por 5 minutos. O sobrenadante foi removido e o precipitado ressuspendido em $200 \mu \mathrm{l}$ da solução I (50 mM Tris-HCl, Ph 8.0; 10 mM EDTA, 100 g/RNase A) e homogeneizados. $200 \mu \mathrm{l}$ da solução II ( $200 \mathrm{mM} \mathrm{NaOH}, 1 \%$ de SDS) foram adicionados, a amostra misturada por inversão e incubada à temperatura ambiente por 5 minutos. Em seguida, $200 \mu \mathrm{l}$ da solução III ( $\mathrm{NaAc} 3 \mathrm{M}, \mathrm{pH}$ 4.8) foram adicionados e a amostra foi homogeneizada oito vezes por inversão e incubada por 30 minutos em gelo. Após a 
centrifugação por 15 minutos a $17.000 \mathrm{~g}, 400 \mu \mathrm{l}$ do sobrenadante foram transferidos para um tubo contendo $300 \mu \mathrm{l}$ de isopropanol e novamente centrifugados a $17.000 \mathrm{~g}$. O sobrenadante foi descartado, o DNA presente no precipitado lavado com um $\mathrm{ml}$ de etanol 70\% e centrifugado novamente. O pellet de DNA foi colocado no Speedvac (Concentrator5301 - Eppendorf AG, Alemanha) e armazenado até o momento do uso.

\subsubsection{Produção do Vetor lentiviral}

Para a produção do vetor lentiviral foi utilizado o protocolo sugerido pelo fornecedor do plasmídeo pLKO.1 (addgene - Prof. Dr Didier Trono, LaboratoryofVirologyandGenectics, EPFL, France). Resumidamente, $2 \times 10^{6}$ células da linhagem HEK293T foram distribuídas em placas de petri de $10 \mathrm{~cm}$ e deixadas em cultura a $37^{\circ} \mathrm{C}$ e $5 \% \mathrm{CO}_{2}$ por 24 horas. Uma solução de transfecção foi preparada com $20 \mu \mathrm{g}$ do pLKO-shRNA-rab2a, $15 \mu \mathrm{g}$ do plasmídeo contendo gag e pol, e seis $\mu \mathrm{g}$ do plasmídeo contendo o envelope VSVG, $50 \mu \mathrm{lde} \mathrm{CaCl}_{2} 2.5 \mathrm{M}$, $500 \mu \mathrm{l}$ de HBS 2x ( $\mathrm{NaCl} 280$ mM, Hepes 100 mM, Na $\mathrm{HPO}_{4} 1.5 \mathrm{mM}$, pH 7) e $\mathrm{H}_{2} \mathrm{O}$ para completar um ml.A solução foi incubada por 15 minutos a temperatura ambiente e em seguida gotejada sobre as células. Após quatro horas, o meio de cultura foi trocado. 0 meio foi coletado a cada 24 horas por dois dias e em seguida filtrado $(22 \mu \mathrm{M})$ e concentrado.

\subsubsection{Protocolo De Infecção Lentiviral De Células Primárias Em Suspenção}

No dia 1 do protocolo, $6 \times 10^{6}$ linfócitos T CD8 isolados de baço e linfonodos de camundongos C57BL/6 e purificados por meio do protocolo de separação com beads magnéticas foram ressuspendidos em seis $\mathrm{ml}$ de meio suplementado contendo oito $\mu \mathrm{g} / \mathrm{ml}$ de Polibrene (Sima Aldrich) e 0,1 ml de vírus (inicialmente testamos um baixo MOI, e como o resultado não foi satisfatório, tentamos novamente com um alto $\mathrm{MOI}$, adicionando $0,5 \mathrm{ml}$ de vírus, ao invés de 0,1 ml) e colocados em uma placa de cultura de $6 \mathrm{~cm}$. Após uma incubação de 24 horas, as células foram centrifugadas e o meio trocado por seis $\mathrm{ml}$ de meio fresco contendo as concentrações ótimas de Puromicina previamente determinadas. As células foram cultivadas na presença de Puromicina por mais dois dias e então o meio trocado e substituído por meio fresco nas mesmas condições descritas anteriormente. $1 \times 10^{6}$ células 
foram coletadas e submetidas ao protocolo de extração de mRNA e PCR Real Time para avaliação da expressão gênica.

\subsubsection{Ensaio para determinação da concentração ótima de Puromicina}

Dia 0: Plaqueamento de $1 \times 10^{6}$ células/poço num volume final de um $\mathrm{ml}$ de meio completo (conforme descrito anteriormente) em placas de 24 poços. Cada poço continha doses crescentes de puromicina (Sigma-Aldrich) nas concentrações 0,5 $\mu \mathrm{g} / \mathrm{ml} ; 1 \mu \mathrm{g} / \mathrm{ml} ; 2$ $\mu \mathrm{g} / \mathrm{ml} ; 4 \mu \mathrm{g} / \mathrm{ml}$ e $10 \mu \mathrm{g} / \mathrm{ml}$, respectivamente. O experimento foi realizado em triplicata. Incubação por 24 horas, 48 horas e 72 horas a $37^{\circ} \mathrm{C}, 5 \%$ de $\mathrm{CO}_{2}$.

Dias1, 2 e 3: Cada ponto da curva foi coletado diariamente e as células foram marcadas com o corante de viabilidade LIVE/DEAD $^{\circledR}$ (Invitrogen), fixadas com PFA $1 \%$ a analisadas por citometria de fluxo no FACS Canto II (BD Bioscience). As porcentagens de células mortas ao longo do tempo foram plotadas em um gráfico.

\subsection{Protocolo de imunofluorescência para citometria de fluxo}

Para as análises por citometria de fluxo utilizamos o protocolo a seguir. As suspensões celulares foram preparadas em um tampão específico para citometria de fluxo (PBS+ 0,5\% BSA + 2 mM EDTA) e foram realizadas as respectivas marcações para cada ensaio. Com o auxílio de uma câmara de Neubauer, $5 \times 10^{5}$ células foram transferidas para um tubo de citometria de fluxo (Facs Calibur) e centrifugadas por 240 g por 5 minutos. 0 sobrenadante foi removido e substituído pelo mix de anticorpos utilizados em cada experimento num volume de $25 \mu \mathrm{l}$, diluídos no tampão de citometria e incubados por 30 minutos no escuro à $4{ }^{\circ} \mathrm{C}$. Após o período de incubação, as células foram centrifugadas novamente e lavadas três vezes com tampão de citometria e fixadas com $100 \mu \mathrm{l}$ paraformaldeído $1 \%$ diluído em PBS ou então se substituiu o fixador por $100 \mu \mathrm{l}$ de Cytofix/Cytoperm (BD Bioscience) durante 20 minutos no gelo, caso tenha sido efetuada alguma marcação intracelular. Após isso, as células foram lavadas duas vezes com $250 \mu \mathrm{l}$ de tampão Perm/Wash e foi feita a marcação com os receptivos anticorpos num volume de 25 $\mu l$, diluídos no tampão de citometria e incubados por 30 minutos no escuro à $4{ }^{\circ} \mathrm{C}$. Por fim, as células foram lavadas mais duas vezes com $250 \mu \mathrm{l}$ de tampão Perm/Wash e fixadas com 
paraformaldeído 1\% diluído em PBS. Para cada análise foram adquiridos pelo menos 300.000 eventos no citômetro de fluxo BD FACS CANTO II e os dados foram analisados com o software de análise FlowJo (Tree Star).

\subsection{Protocolo de extração de mRNA e PCR Real Time}

\subsubsection{Extração de RNA com Trizol}

Entre $1 \times 10^{6}-1 \times 10^{7}$ células foram transferidas para um tubo Eppendorf e centrifugadas por 5 minutos à $300 \mathrm{~g} \mathrm{e} 4^{\circ} \mathrm{C}$. Em seguida, o sobrenadante foi descartado e o pellet foi ressuspendido com $500 \mu \mathrm{l}$ de Trizol (nessa etapa o experimento pode ser pausado e as amostras congeladas em $-80{ }^{\circ} \mathrm{C}$ para posterior processamento). As amostras foram incubadas por 5 minutos e em seguida adicionamos $100 \mu \mathrm{l}$ de clorofórmio, homogenizamos vigorosamente por 15 segundos e incubamos à temperatura ambiente por 3 minutos. As amostras foram então centrifugadas por $12000 \mathrm{~g}$ durante 15 minutos à $4{ }^{\circ} \mathrm{C}$. Após a centrifugação, observamos a formação de diferentes fases e removemos a fase aquosa superior, tomando cuidado para não aspirar a camada protéica. Adicionamos $250 \mu \mathrm{l}$ de isopropanol e vortexamos por 10 segundos e incubamos por 45 minutos à temperatura ambiente. Após a incubação, as amostras foram centrifugadas por 12000 g por 15 minutos à $4{ }^{\circ} \mathrm{C}$ e então removemos cuidadosamente o sobrenadante e o descartamos. O pellet foi lavado com $500 \mu \mathrm{l}$ de etano $75 \%$ e centrifugado por $7500 \mathrm{~g}$ por 5 minutos à $4{ }^{\circ} \mathrm{C}$. $\mathrm{O}$ sobrenadante foi descartado e o tubo foi mantido em um fluxo laminar aberto para secar. Após seco, o pellet foi ressuspenso em $20 \mu \mathrm{l}$ de $\mathrm{H}_{2} \mathrm{O}$ DNAse/RNAse free e deixado por 1 hora à $4{ }^{\circ} \mathrm{C}$. As concentrações foram analisadas por espectrofotometria no NanoDrop (Thermo Scientific) e foram avaliadas as purezas das amostras por meio das relações $(260 \mathrm{~nm} / 280$ $\mathrm{nm})$. Foi então preparado um gel de agarose a $1 \%$ e então aplicamos 2-5 $\mu \mathrm{l}$ da amostra e então realizamos uma corrida à $45 \mathrm{~mA}$ durante cerca de 3 horas. $\mathrm{O}$ gel foi corado com brometo de etídio para observação da integridade do material.

\subsubsection{Conversão do mRNA em cDNA}

Adicionamos um $3 \mu \mathrm{g}$ de mRNA e o volume foi completado para $12 \mu \mathrm{l}$ com $\mathrm{H}_{2} \mathrm{O}$ DNAse/RNAse free em tubos para PCR. Em seguida adicionamos $1 \mu \mathrm{l}$ de oligoDT e $1 \mu \mathrm{l}$ de 
dNTP mix. Em seguida aquecemos os tubos à $65{ }^{\circ} \mathrm{C}$ no termociclador por 5 minutos e por mais 1 minuto no gelo. Adicionamos $4 \mu \mathrm{l}$ de $5 x$ first strand buffer, $1 \mu$ le DTT 0,1 M, $1 \mu$ de Super Script III RT $200 \mathrm{U} / \mu \mathrm{l}$. Finalmente incubamos por $50{ }^{\circ} \mathrm{C}$ por 60 minutos e mais 15 minutos à $70^{\circ} \mathrm{C}$. As amostras foram mantidas em freezer $-20^{\circ} \mathrm{C}$ até o momento do uso.

\subsubsection{PCR Real Time para actina}

Esta etapa foi incluída como um controle de qualidade da etapa de conversão do mRNA em cDNA. Para esta etapa selecionamos o gene da Actina para realização de uma PCR e avaliação da qualidade das bandas geradas por meio de uma corrida eletroforética em gel de agarose a 1,5\% e 1\% de GelRed (UniScience, SP, BR) para visualização das bandas.

Em resumo, $1 \mu$ do cDNA foi colocado em um tubo de PCR e adicionamos $5 \mu$ de tampão 10 x; $1,5 \mu \mathrm{l}$ de $\mathrm{MgCl}_{2} ; 1 \mu \mathrm{l}$ de dNTP mix; $1 \mu \mathrm{l}$ de primer forward para Actina murina; 1 $\mu \mathrm{l}$ de primer reverse para Actina murina; $0,5 \mu \mathrm{l}$ de Taq DNA polimerase e $39 \mu \mathrm{l}$ de $\mathrm{H}_{2} \mathrm{O}$ MILIQ autoclavada. O termociclador foi setado conforme a tabela abaixo:

\begin{tabular}{|c|c|c|}
\hline N. de Ciclos & Temperatura & Tempo \\
\hline $1 \mathrm{X}$ & $95^{\circ} \mathrm{C}$ & 5 minutos \\
\hline $30 \mathrm{X}$ & $95^{\circ} \mathrm{C}$ & 45 segundos \\
\hline $30 \mathrm{X}$ & $68^{\circ} \mathrm{C}$ & 1 minuto \\
\hline $30 \mathrm{X}$ & $72^{\circ} \mathrm{C}$ & 45 segundos \\
\hline $1 \mathrm{X}$ & $72^{\circ} \mathrm{C}$ & 2 minutos \\
\hline
\end{tabular}

Tabela 2 - Tabela contendo informações sobre o ciclo realizado no termociclador para conversão do mRNA em cDNA

Após a reação, $5 \mu \mathrm{l}$ do produto de PCR foram adicionados a $1 \mu \mathrm{l}$ de azul de bromofenol e colocados em um gel de agarose a 1,5\% e 1\% de GelRed (UniScience) por aproximadamente 1,5 hora à $70 \mathrm{mV}$, juntamente com a adição de um marcador de padrões moleculares e revelados em um transiluminador. 


\subsection{Protocolo De Edição Genômica Utilizando A Ferramenta De Biologia Molecular CRISPR/CAS-9}

\subsubsection{Digestão do vetor lentiviral lentCRISPR v2}

Cinco $\mu \mathrm{g}$ de lentiCRISPR v2 (Addgene) (figura 10) foram misturados a 0,5 $\mu$ l da enzima BsmBI (New England Biolabs) com mais seis $\mu$ l de tampão NEBuffer 3.1 (New England Biolabs) mais 0,6 $\mu$ l de DTT $100 \mathrm{mM}$ (Bio-Rad, Hercules, CA, EUA) e o volume final foi acertado para $60 \mu \mathrm{l}$ com água destilada. A reação foi incubada por três horas à $55{ }^{\circ} \mathrm{C}$ em um aparelho Thermomixer (Thermo Fisher).

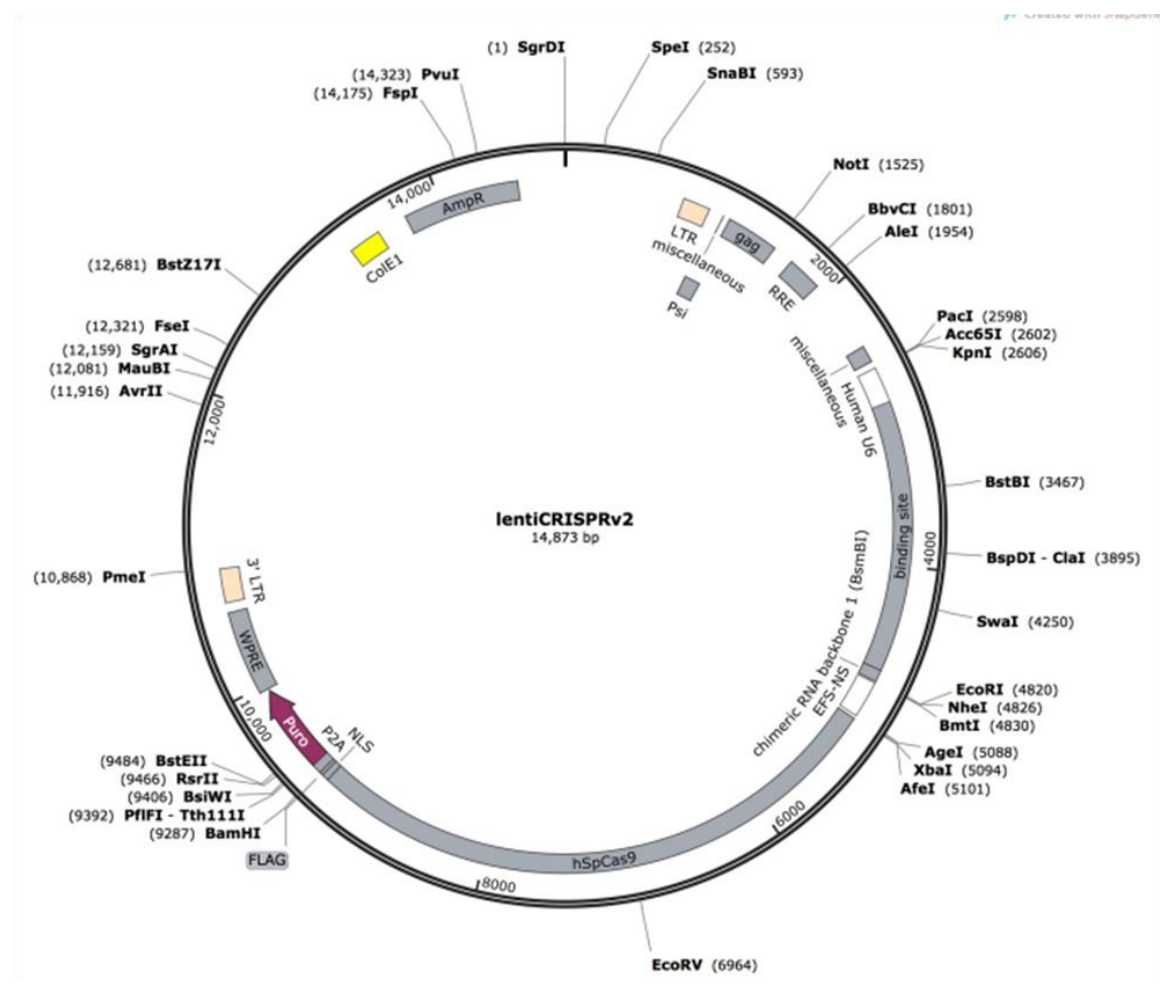

Figura 10 - Imagem representativa do plasmídeolentiCRISPRv2 contendo o marcador de seleção PURO (gene que confere resistência à Puromicina), AmpR (resistência a ampicilina),os sítios de clivagem para diversas enzimas, o promotor humano U6, a sequência da nikase hspCas9 (Fonte: Improved vectors and genome-wide libraries for CRISPR screening. Sanjana NE, Shalem O, Zhang F. Nat Methods. 2014 Aug;11(8):783-4. doi: 10.1038/nmeth.3047. 10.1038/nmeth.3047).

\subsubsection{Purificação do plasmídeo digerido em gel de agarose}

Para purificação do plasmídeo digerido (ver item anterior) foi feita inicialmente uma corrida eletroforética do produto da digestão em gel de agarose a $1 \%$ e $70 \mathrm{~V}$ por aproximadamente uma hora. Para identificação do material no gel foi utilizado o reagente GelRed (Biotium) e um marcador de $1 \mathrm{~Kb}$ (Thermo Fisher). A banda correspondente ao plasmídeo digerido (aproximadamente $13 \mathrm{~kb}$ ) foi recortada com o auxílio de uma lâmina de 
bisturi estéril, e purificada utilizando o QIAquick Gel Extraction Kit (Qiagen), cujo protocolo pode ser visto de maneira resumida a seguir:

O fragmento do gel contendo a banda de interesse foi colocado em um microtubo e pesado. Após a pesagem foram adicionados três volumes de tampão QG (fornecido) e incubados por 10 minutos à $50^{\circ} \mathrm{C}$ até que o gel estivesse completamente dissolvido. Foi feita a precipitação do material com isopropanol, purificação utilizando as colunas fornecidas pelo kit e quantificação com um NanoDrop 2000 (Thermo Fisher).

\subsubsection{Desenho e validação do Grna}

Foram utilizadas as ferramentas online DNA2.0 gRNA Design Tool (https://www.dna20.com) e gRNA design tool (http://www.genscript.com) da GenScript para desenvolver as sequências de gRNA. As sequências passaram por um controle de qualidade adicional utilizando o programa Matcher Mobile Pasteur (http://mobyle.pasteur.fr/cgi-bin/portal.py\#forms::matcher).

\subsubsection{Fosforilação e anelamento dos pares de oligos}

Foram adquiridos dois pares de primers customizados para diferentes regiões do gene da proteína de estudo denominados RAB2A-1 (Forward: 5' CACCGTACATCATAATCGGCGACAC 3' e Reverse: 5' AAACGTGTCGCCGATTATGATGTAC 3') e RAB2A-2 (Forward: 5' CACCGGCCGGCGGCCGCAGAACTTC 3' e Reverse: 5' AAACGAAGTTCTGCGGCCGCCGGCC 3') (Thermo Fisher) e preparado um mix com as especificações abaixo:

$1 \mu \mathrm{l}$ do oligo Forward $(100 \mu \mathrm{M})$ foi misturado a um $\mu$ l oligo Reverse $(100 \mu \mathrm{M})$ e um $\mu \mathrm{l}$

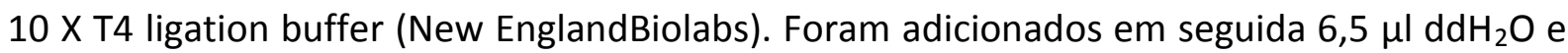
0,5 $\mu$ I T4 PNK (New EnglandBiolabs). A reação foi colocada em um termociclador (Thermo Fisher) utilizando os seguintes parâmetros:

$37^{\circ} \mathrm{C}-30$ minutos

$95{ }^{\circ} \mathrm{C}-5$ minutos 
Rampdown até $25^{\circ} \mathrm{C}$ numa taxa de $5^{\circ} \mathrm{C} /$ minuto

* Os oligos da etapa 3 foram diluídos com água livre de DNAse/RNAse numa proporção de 1:200 e armazenados a $-20^{\circ} \mathrm{C}$ até o uso.

\subsubsection{Reação de ligação dos oligos anelados ao plasmídeo digerido}

Foram preparadas três reações em microtubos de 200 microlitros:

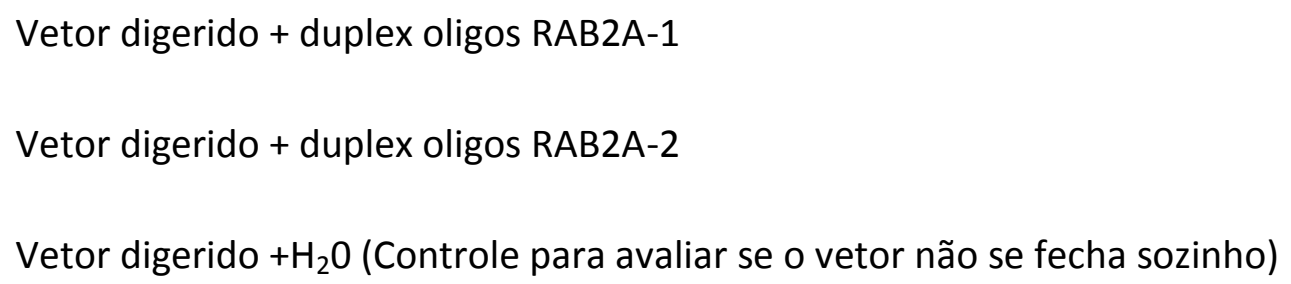

$50 \mathrm{ng}$ do plasmídeo digerido com BsmBI (passo 2) foram adicionados a dois $\mu \mathrm{L}$ do duplex de oligos diluídos (passo 3) e um $\mu \mathrm{L}$ de 10 X T4 DNA ligase (New EnglandBiolabs), além de 4,6 $\mu \mathrm{L}$ dd $\mathrm{H}_{2} \mathrm{O}$ e um $\mu \mathrm{l}$ de T4 DNA ligase (New EnglandBiolabs).A reação foi colocada overnight em um Thermomixer (Thermo Fisher) à $16^{\circ} \mathrm{C}$.

\subsubsection{Transformação Bacteriana}

Em microtubos de 1,5 mL, foram adicionados 10 microlitros do produto das reações de ligação preparadas no item 4 (Vetor digerido + duplex oligos RAB2A-1; Vetor digerido + duplex oligos RAB2A-2; Vetor digerido $+\mathrm{H}_{2} \mathrm{O}$ ) a 100 microlitros de bactérias competentes stbl3 previamente preparadas, seguido de incubação em gelo por 30 minutos. Imediatamente após incubação no gelo foi realizado o choque térmico a $42{ }^{\circ} \mathrm{C}$ por 45 segundos em bloco aquecedor, seguido de nova incubação em gelo por mais dois minutos. Foram adicionados um $\mathrm{mL}$ de meio LB sem antibiótico à temperatura ambiente e os tubos foram homogeneizados por inversão. Uma nova incubação de 45 minutos à $37^{\circ} \mathrm{C}$ em bloco aquecedor foi feita e após esse período as bactérias foram centrifugadas a $6000 \mathrm{~g}$ durante cinco minutos à temperatura ambiente. Ao final da centrifugação o sobrenadante foi desprezado e foram adicionados 100 microlitros de meio LB fresco, o pellet ressuspendido, homogeneizado e transferido para uma placa contendo meio LB ágar com ampicilina (100 
$\mu \mathrm{g} / \mathrm{ml}$ ) e homogeneizado com esferas de vidro. As placas contendo as bactérias foram mantidas overnight em incubadora à $37^{\circ} \mathrm{C}$.

\subsubsection{PCR de colônia para avaliação da transformação das bactérias stb/3}

Para realização da PCR de colônia foi preparado um mix da seguinte maneira para cada amostra: 2,5 $\mu \mathrm{L}$ de Buffer $10 \times$ (Sigma-Aldrich) foram misturados a 0,75 $\mu \mathrm{L}$ de $\mathrm{MgCl}_{2}(50 \mathrm{mM}$ ) (Sigma-Aldrich) e 0,5 $\mu \mathrm{L}$ dNTP (10 $\mu \mathrm{M}$ ) (Sigma-Aldrich) com 0,5 $\mu \mathrm{L}$ Primer Forward U6 (100 $\mu \mathrm{M})$ e 0,5 $\mu \mathrm{L}$ Primer Reverse gRNA (RAB2A-1 e RAB2A-2) (100 $\mu \mathrm{M})$ mais 0,25 $\mu \mathrm{L}$ Taq DNA polimerase e $20 \mu \mathrm{L} \mathrm{H} \mathrm{H}_{2} \mathrm{O}$ DNAse/RNAse free. $25 \mu \mathrm{L}$ desse mix foram adicionados a microtubos de $200 \mu \mathrm{L}$ para reações de PCR e em seguida foram utilizadas ponteiras estéreis para fazer um pique em diferentes colônias da placa de ágar. A ponteira contendo a colônia escolhida foi lavada nos $25 \mu \mathrm{L}$ de mix do microtubo e os tubos submetidos a uma reação de PCR com a ciclagem abaixo:

1 minuto a $94^{\circ} \mathrm{C}$

30 segundos a $94^{\circ} \mathrm{C}(35 \mathrm{X})$

30 segundos a $49^{\circ} \mathrm{C}(35 \mathrm{X})$

45 segundos a $72{ }^{\circ} \mathrm{C}(35 \mathrm{X})$

5 minutos a $72{ }^{\circ} \mathrm{C}$

O termociclador foi configurado para permanecer a $4{ }^{\circ} \mathrm{C}$ ao final dos ciclos até $\mathrm{O}$ momento da retirada dos tubos. Foram coletadas oito colônias e submetidas a verificação pela reação de PCR. Além disso, foi incluído um controle negativo em que a ponteira foi mergulhada em $\mathrm{H}_{2} \mathrm{O}$ DNAse/RNAse free.

O produto de PCR foi submetido a uma corrida eletroforética em gel de agarose a $1 \%$ corado com GelRed (Biotum) a $60 \mathrm{~V}$ e revelado em um transiluminador. Foi utilizado um marcador molecular de 1 kDa para ajudar na identificação das bandas. 


\subsubsection{Mini-preparação de clones de bactérias transformadas}

Seis clones das bactérias preparadas conforme os itens anteriores foram selecionados para prosseguir com o protocolo, sendo três RAB2-1 e três RAB2-2. O protocolo utilizado para os seis clones foi o mesmo e segue em detalhes abaixo.

Foi preparado um meio de cultura LB líquido com os seguintes reagentes:

5 g Bacto-peptona (BD Bioscience)

2,5 g extrato de levedura (Acumedia, Lansing, MI, EUA)

5 g Cloreto de Sódio (Synth, SP, BR)

Água Miliq.q.s.p. $500 \mathrm{ml}$

$\mathrm{O}$ pH foi ajustado para 7.0 e o meio foi autoclavado

Em seguida, foram utilizados tubos snap-caps (Thermo Fischer) com $5 \mathrm{ml}$ do meio LB líquido contendo ampicilina (100 $\mu \mathrm{g} / \mathrm{ml})$ nos quais foram colocadas as colônias selecionadas (gRNA 1-1, gRNA 1-2, gRNA 1-3, gRNA 2-1, gRNA 2-2, gRNA 2-3) com o auxílio de ponteiras estéreis. Os tubos foram incubados overnight em um agitador orbital a $37{ }^{\circ} \mathrm{C}$ e $300 \mathrm{RPM}$. Após a incubação, as amostras foram submetidas ao protocolo de miniprep (Qiagen).

Inicialmente, as bactérias foram transferidas para microtubosde $1,5 \mathrm{ml}$ e centrifugadas a velocidade máxima em temperatura ambiente. Em seguida, todo sobrenadante foi removido e o protocolo da miniprep foi realizado conforme as indicações do fabricante.

Em suma, foi realizada a lise das bactérias utilizando reagentes fornecidos, em seguida o produto da lise é transferido para colunas de sílica nas quais o plasmídeo se liga e após uma série de lavagens e centrifugações para remoção de impurezas, o plasmídeo puro é eluído da coluna e recuperado. Os plasmídeos foram quantificados com o auxílio de um NanoDrop 2000 (Thermo Fischer). 


\subsubsection{Sequênciamento dos plasmídeos}

As amostras RAB2 gRNA 1-1, gRNA 1-2, gRNA 1-3, gRNA 2-1, gRNA 2-2, gRNA 2-3 foram submetidas a uma reação de sequênciamento a fim de validar a presença dos gRNAs inseridos nos plasmídeos. Foi preparado um master mix para cada uma das amostras contendo $150 \mathrm{ng}$ do respectivo plasmídeo, 0,5 $\mu \mathrm{L}$ de primer U6, $3 \mu \mathrm{Lde} 5 \mathrm{X}$ sequence buffer (Thermo Fisher), $2 \mu \mathrm{L}$ de Big Dye (Thermo Fisher) e o volume foi completado para $15 \mu \mathrm{L}$ com água miliq. A mistura sofreu um pequeno spin e permaneceu overnight no thermociclador com a seguinte programação:

2 minuto a $96{ }^{\circ} \mathrm{C}$

45 segundos a $96^{\circ} \mathrm{C}(35 \mathrm{X})$

30 segundos a $50{ }^{\circ} \mathrm{C}(35 \mathrm{X})$

4 minutos a $60^{\circ} \mathrm{C}(35 \mathrm{X})$

Permanecer em $4{ }^{\circ} \mathrm{C}$ após o término dos ciclos

No dia seguinte foi realizada a precipitação da amostra utilizando para este fim glicogênio. Foi preparado no gelo um coquetel com $15 \mu \mathrm{L}$ da reação de PCR mais $23,2 \mu \mathrm{L}$ de etanol gelado, $1,1 \mu \mathrm{L}$ de acetato de sódio $3 \mathrm{M} \mathrm{pH}$ 5,2 e 1,1 $\mu \mathrm{L}$ de glicogênio $1 \mathrm{ng} / \mathrm{mL}$. Tudo foi vortexado e deixado repousando no gelo por dez minutos. Em seguida, foi feita uma centrifugação de 4000 RPM por 20 minutos à temperatura ambiente e em seguida o sobrenadante foi removido e adicionado $50 \mu \mathrm{L}$ de etanol $70 \%$ gelado. Nova centrifugação foi efetuada a 4000 RPM por 10 minutos em temperatura ambiente. Novamente o sobrenadante foi removido e o tubo foi seco e envolto em papel alumínio e encaminhado para o laboratório de seqüenciamento para análise no equipamento 3100 Avant Genetic Analyser (Thermo Fisher) e os resultados analisados no programa 4Peaks (Nucleobytes, Aalsmeer, The Netherlands).

\subsubsection{Transfeç̧ão de Células HEK293T}

O protocolo para produção das partículas virais iniciou-se com a transfecção da linhagem celular HEK293T. O protocolo em detalhes segue adiante: 
1음a

$2 \times 10^{5}$ células HEK 293T foram plaqueadas em poços de placas de seis poços num volume de três $\mathrm{ml}$ de meio DMEM $10 \%$.

2ㅇia

Após confirmação de que as células se encontravam com no mínimo $80 \%$ de confluência, foi preparado um mix contendo cinco ML de DMEM sem soro, $1 \mu \mathrm{g} / \mathrm{ml}$ do plasmídeo psPAX2 (segunda geração de plasmídeo de empacotamento lentiviral) (Addgene), 2,5 $\mathrm{gg} / \mathrm{ml}$ do plasmídeo pCMV-VSV-G (proteína de envelope para a produção de partículas lentivirais) (Addgene), além de $22,5 \mu \mathrm{L}$ do reagente de transfecção polietilenimina (PEI) (Sigma-Aldrich) e cinco $\mu$ g dos plasmídeos LentCRISPRv2 portando as sequências de interesse. Foi incluído um plasmídeo contendo uma sequência irrelevante para humanos e este foi denominado human non target control (HUNTC) e outro contendo um gene RFP para o receptor de interferon a fim de verificar a internalização do plasmídeo nas condições do experimento. A mistura foi homogenizada e gotejado $1 \mathrm{ml}$ sobre os respectivos poços.

O sobrenadante foi coletado após 24 horas, 48 horas e 72 horas, centrifugado a 1500 RPM por 5 minutosà $4{ }^{\circ} \mathrm{C}$ e armazenado em freezer $-80^{\circ} \mathrm{C}$ até a utilização.

\subsubsection{Transdução de células YT utilizando partículas lentivirais}

$5 \times 10^{5}$ células YT foram plaqueadas em placas de seis poços num volume final de 1 $\mathrm{ml}$ de meio RPMI. Sobre cada poço foi gotejado $1 \mathrm{ml}$ dasolução contendo as partículas virais produzidas com 48 horas de transfecção e mais dois $\mu \mathrm{L}$ do polímero catiônico polibrene (Sigma-Aldrich) a fim de aumentar a eficiência da transdução. Foram utilizados os vírus contendo a sequência RAB2-1, RAB2-2, HUNTC e foi incluído um controle contendo somente pCMV-VSV-G, psPAX2 e PEI.

24 horas após a transdução, as células foram coletadas, centrifugadas a 1500 RPMI durante cinco minutos e lavadas com meio RPMI fresco. As células foram então ressuspendidas em meio RPMI contendo $4 \mu \mathrm{g} / \mathrm{ml}$ de puromicina(concentração previamente determinada) e plaqueadas em placas de 24 poços e mantidas em cultura por cinco dias. 
Após esse período, as células remanescentes foram recolhidas, centrifugadas e plaqueadas novamente em meio com antibiótico, expandidas e congeladas.

\subsection{Western-blot}

O lisado protéico foi preparado a partir de uma alíquota da ordem de $10^{6}$ células, centrifugadas a $240 \mathrm{~g}$ por 5 minutos a $4{ }^{\circ} \mathrm{C}$ e o sedimento celular foi solubilizado em $100 \mu \mathrm{L}$ de tampão de lise $[50 \mathrm{mM}$ Tris- $\mathrm{HCl}, \mathrm{pH}$ 6,8; $2 \%$ SDS, $10 \%$ glicerol e 2,5\% de $\beta$ mercaptoetanol], aquecido a $100{ }^{\circ} \mathrm{C}$ por 5 minutos, depois resfriado a $4{ }^{\circ} \mathrm{C}$ por 1 minuto e estocado a $-20^{\circ} \mathrm{C}$. As amostras foram aplicadas em gel de poliacrilamida de diferentes porcentagens de acordo com o tamanho da proteína de interesse e foram submetidas à carga elétrica por $2 \mathrm{~h} 30$ minutos a 80-100 V para realização da eletroforese. Em seguida, as proteínas do gel foram transferidas para uma membrana de PVDF de 0,22 $\mu$ m (Millipore Corporation, Billerica, MA, EUA), bloqueadas com solução de bloqueio [tampão TBS pH $7.5+$ 0,3\% Tween $20+5 \%$ leite desnatado]e incubadas com os anticorpos específicos. A detecção dos imunocomplexos foi realizada pelo método de quimioluminescência utilizando o $\mathrm{ECL}$ preparado pelo laboratório [Solução A: $9 \mathrm{~mL} \mathrm{H} \mathrm{H}_{2} \mathrm{O}, 1 \mathrm{~mL}$ Tris/HCL $1 \mathrm{M} \mathrm{pH} \mathrm{8.5,} 22 \mu \mathrm{L} p$ Coumaric acid 90 mM, $50 \mu \mathrm{L}$ Luminol 250 mM e Solução B: $900 \mu \mathrm{L} \mathrm{H} \mathrm{H}_{2} \mathrm{O}$ e $100 \mu \mathrm{L} \mathrm{H}_{2} \mathrm{O}_{2}$ 30\%], com posterior exposição das membranas a um aparelho ImageQuant LAS 500 (GE Healthcare, Little Chalfont, UK)

\subsection{Análises Estatísticas}

As análises estatísticas foram realizadas com o auxílio do software computacional Graphpad Prism, da companhia Graphpad Software Incorporation, versão 5. O teste usado foi o two-way ANOVA, seguido do BONFERRONI e/ou Tukey. 


\section{RESULTADOS}

\subsection{Proteômica}

O trabalho em questão originou-se de um estudo prévio realizado por nosso grupo, no qual grânulos citotóxicos foram isolados e submetidos a esse tipo de análise (AmaranteMendes Et al., dados não publicados). Uma imagem representativa do experimento de proteômica pode ser encontrada abaixo (figura 11) e tabelas contendo os achados desse estudo podem ser encontradas em anexo (Apêndices I e II). Por se tratar de um estudo prévio, não discutiremos com profundidade os resultados obtidos, porém, discutiremos mais adiante acerca do valor dessa metodologia para estudos prospectivos de novos alvos, bem como a sua utilização para o estudo de grânulos citotóxicos.

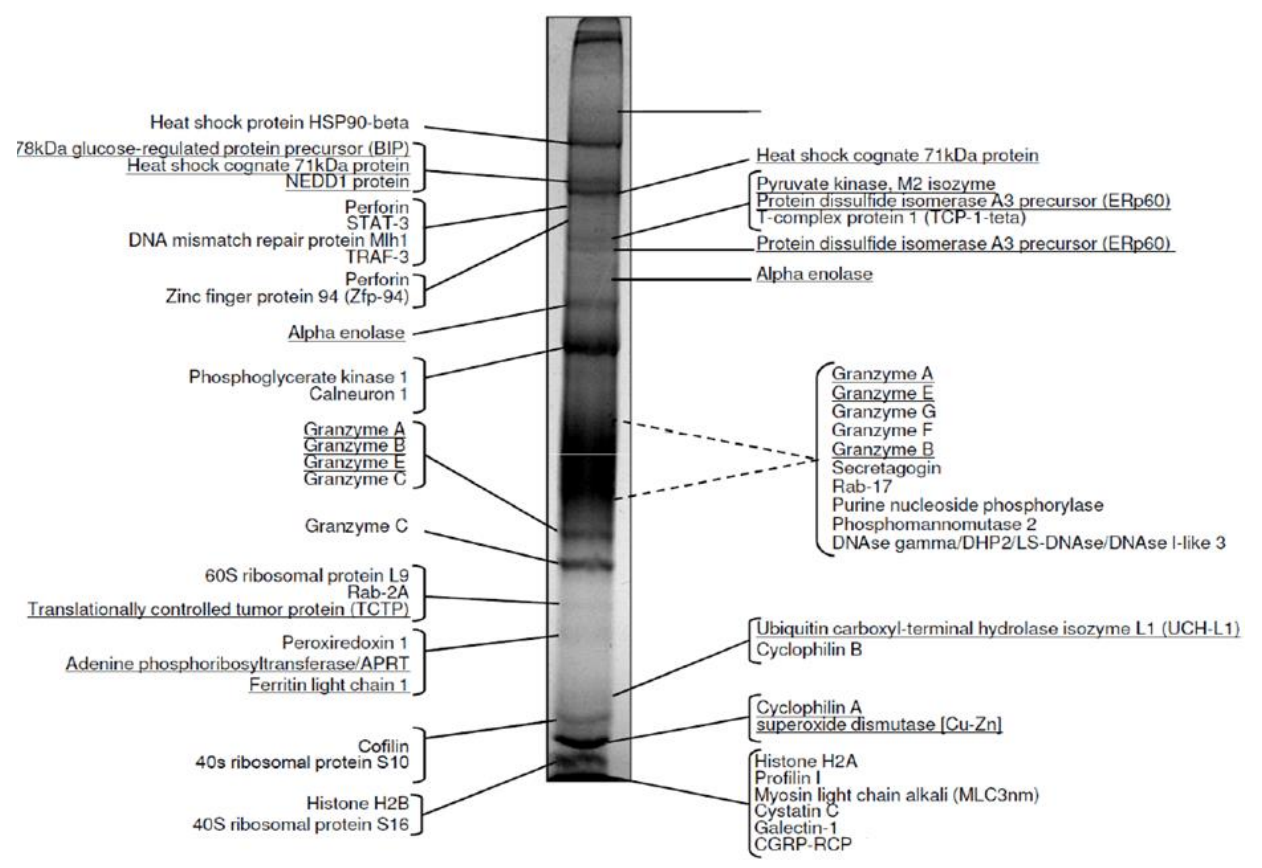

Figura 11 - Marcação com SDS-PAGE seguida de "Coomassie Blue" revelou as bandas mais proeminentes em níveis similares em duas amostras representativas. Essas frações foram enriquecidas por atividade da esterase BLT. Análise por Westernblot revelou que as frações dos grânulos purificados estavam fortemente enriquecidas com perforina, granzima A e B (Amarante-Mendes et al., dados não publicados).

Nosso grupo utilizou essa abordagem experimental partindo de um processo de fracionamento celular de células YT e posterior ultracentrifugação diferencial contra um gradiente para isolar os grânulos citotóxicos de acordo com seu peso. Experimentos de western blot confirmaram o sucesso da purificação (dados não mostrados) e os resultados obtidos com a proteômica corroboram com dados da literatura de experimentos do mesmo tipo, nos quais podemos encontrar diversas proteínas características de grânulos citotóxicos 
como LAMP-1, LAMP-2, granzima A e B, perforina, catepsinas e outras (96). RAB2A, RAB5A, RAB17 e RAB18 foram escolhidas como objeto de investigação deste estudo.

\subsection{Validação dos Resultados Preliminares por Microscopia Confocal}

Embora a análise dos grânulos citotóxicos por meio de técnicas de proteômica seja uma poderosa ferramenta para analisar a composição e função dessas organelas, a técnica em si apresenta alguns problemas e limitações. Um exemplo disso é que apesar do processo de separação dos grânulos ter sido feito de acordo com o protocolo, ainda assim encontramos moléculas que sabidamente fazem parte de outras organelas, como é o caso da BiP/GRP70, uma chaperona típica de retículo endoplasmático. Esse é um problema comum entre aqueles que utilizam esta metodologia e uma possível explicação para isso é que a fração correspondente aos grânulos citotóxicos possa ter sido contaminada com outras organelas ou pedaços de membranas de outras organelas. Sendo assim, como acontece em todo experimento de screening de larga escala, os dados de proteômica devem ser validados para que possamos afirmar sem sombra de dúvida que uma proteína está presente em determinada organela e as técnicas escolhidas para este fim foram técnicas de microscopia confocal, que permitem fazer imagens em três dimensões e até mesmo determinar se duas ou mais proteínas encontram-se próximas ou na mesma região, fenômeno ao qual se atribui o nome de colocalização.

O primeiro passo para geração das imagens de microscopia confocal foi a padronização dos anticorpos primários que foram utilizados neste estudo (o protocolo em detalhes pode ser encontrado na seção Materiais e Métodos, assim como os reagentes utilizados). Nós realizamos a padronização dos anticorpos, ou seja, encontramos a concentração ideal para se trabalhar com os anticorpos primários e secundários, de maneira que cada um deles gere uma intensidade ótima de sinal (fluorescência) que seja capturada pelo microscópio. Foram feitas padronizações dos anticorpos contra RAB2A, RAB5A, RAB17, RAB18, LAMP-1, LAMP-2, granzima B, perforina, Faloidina, tubulina e o corante vital para o núcleo Hoechst. Os resultados podem ser observados a seguir. 
3.3 Padronizações dos anticorpos utilizados nos ensaios de microscopia confocal

\subsubsection{Padronização do anticorpo RAB2A}

Para padronização do anticorpo RAB2A nós variamos a concentração do anticorpo primário em 1:50, 1:100 e 1:200. Foram testadas as concentrações de 1:200 e 1:400 do anticorpo secundário. Com este experimento encontramos que a melhor configuração para se trabalhar com o anticorpo RAB2A é 1:50 e a concentração do anticorpo secundário 1:200. Esses resultados podem ser observados na figura 12 .

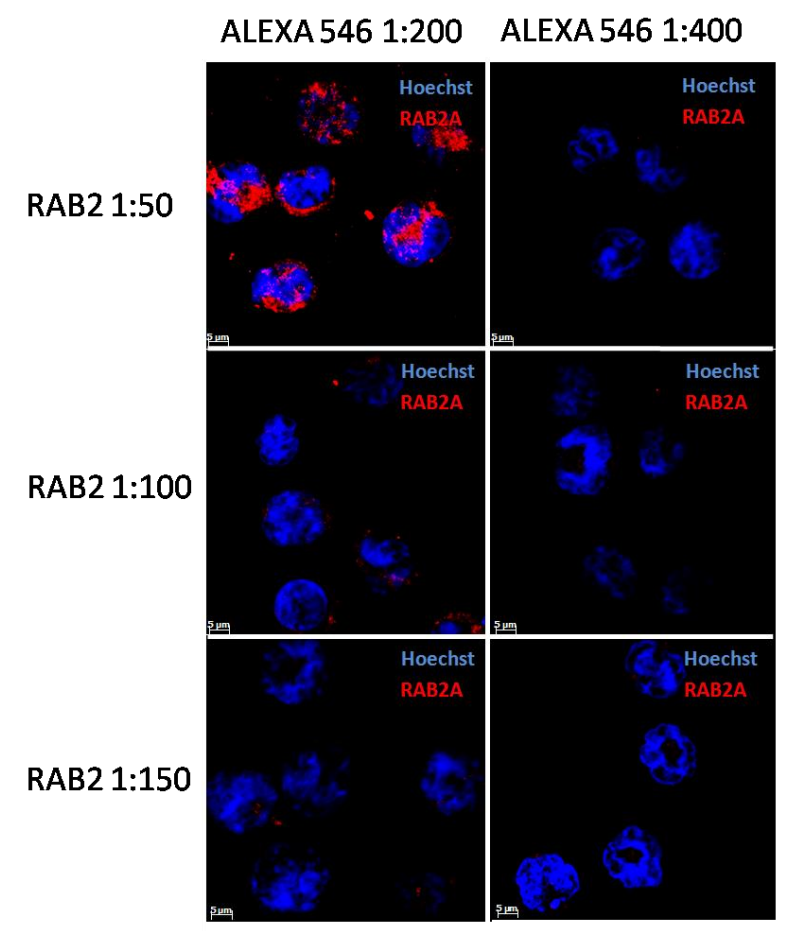

Figura 12 -Padronização do anticorpo RAB2A nas proporções 1:50, 1:100 e 1:150 para identificação dessa proteína em células YT observada por microscopia confocal de fluorescência. Identificação de RAB2A com anticorpo policlonal 26547 (Santa Cruz, CA, USA) detectado com anticorpo secundário anti-lgG de cabra conjugado com AlexaFluor 546 A11056 (Invitrogen, New York, USA) na proporção 1:200 e 1:400. Aumento de 40 x.

\subsubsection{Padronização do anticorpo RAB5A}

Na figura 13 podemos observar a padronização do anticorpo RAB5A, na qual fixamos a concentração do anticorpo primário em 1:50 e variamos a concentração do anticorpo secundário. Com este experimento definimos que a concentração ideal de trabalho com este anticorpo é 1:50 e a concentração do anticorpo secundário 1:200. 


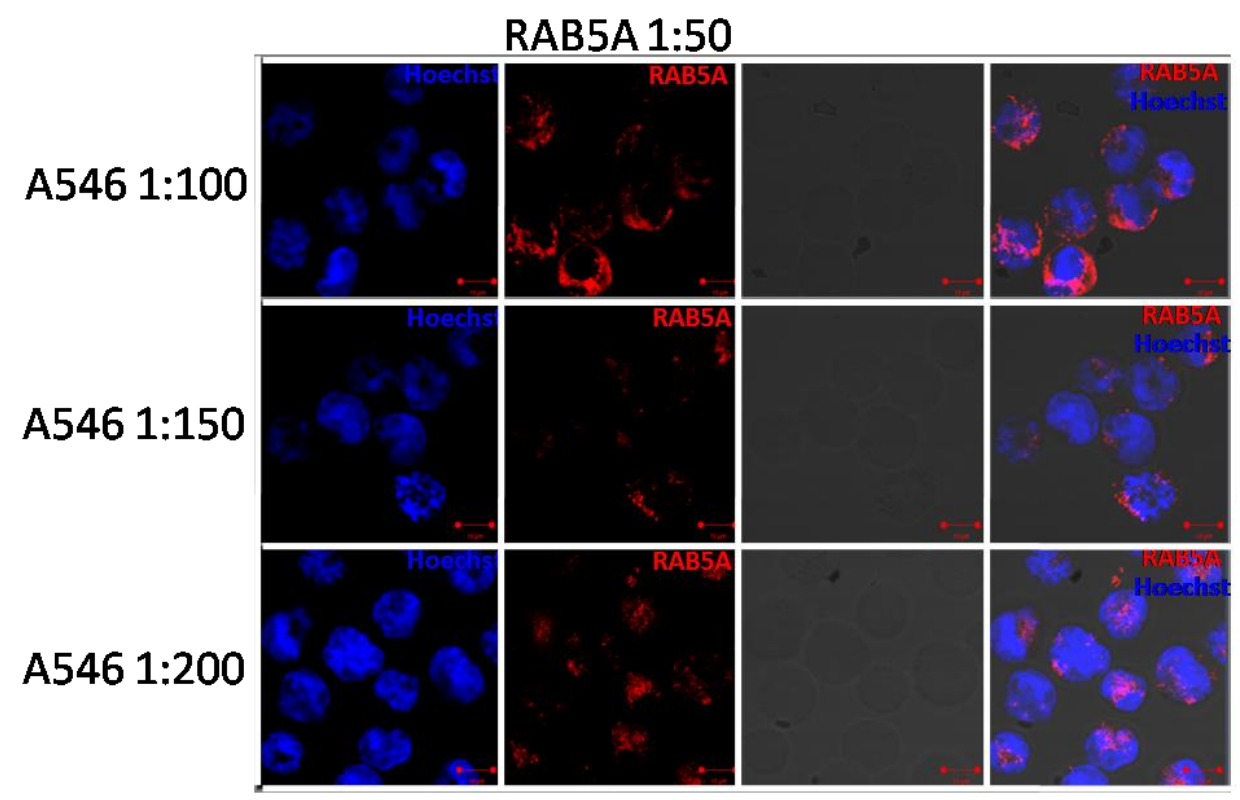

Figura 13 - Padronização do anticorpo RAB5A na proporção 1:50 para identificação dessa proteína em células YT observada por microscopia confocal de fluorescência. Identificação de RAB5A com anticorpo monoclonal AB109534 (Abcam, Cambridge, UK) detectado com anticorpo secundário anti-IgG de coelho conjugado com AlexaFluor 546 A100400 (Invitrogen, New York, USA) nas proporções 1:100, 1:150 e 1:200. Marcação de núcleo com Hoechst. Aumento de 40 x.

\subsubsection{Padronização do anticorpo RAB17}

Para padronização do anticorpo RAB17 nós fixamos a concentração do anticorpo secundário em 1:200 e variamos a concentração do anticorpo primário desde 1:50 até 1:150. Com este experimento encontramos que a melhor configuração para se trabalhar com o anticorpo RAB17 é 1:50 e a concentração do anticorpo secundário 1:200. Esses resultados podem ser observados na figura 14. 


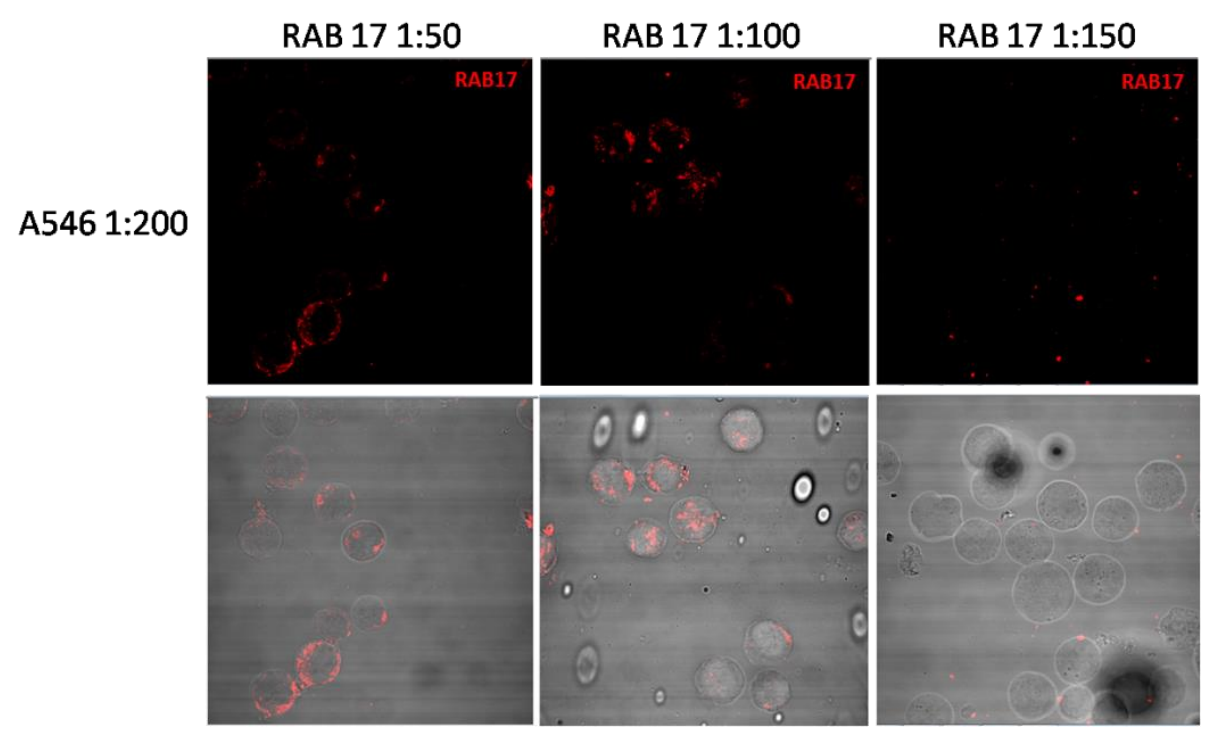

Figura 14- Padronização do anticorpo RAB17 nas proporções 1:50, 1:100 e 1:150 para identificação dessa proteína em células YT observada por microscopia confocal de fluorescência. Identificação de RAB17 com anticorpo policlonal ab-77437 (Abcam, Cambridge, UK) detectado com anticorpo secundário anti-IgG de cabra conjugado com AlexaFluor 546 A11056 (Invitrogen, New York, USA) na proporção 1:200. Aumento de $40 \mathrm{x}$.

\subsubsection{Padronização do anticorpo RAB18}

Inicialmente nós estabelecemos que a concentração ideal do anticorpo RAB18 é 1:50 (dados não mostrados). Em seguida procuramos a concentração ideal do anticorpo secundário. Para isso, variamos a concentração do anticorpo secundário entre 1:200 e 1:400. De acordo com a figura 15, encontramos que a melhor concentração para trabalhar com a RAB18 é 1:50 e a concentração ideal do anticorpo secundário é 1:200. 


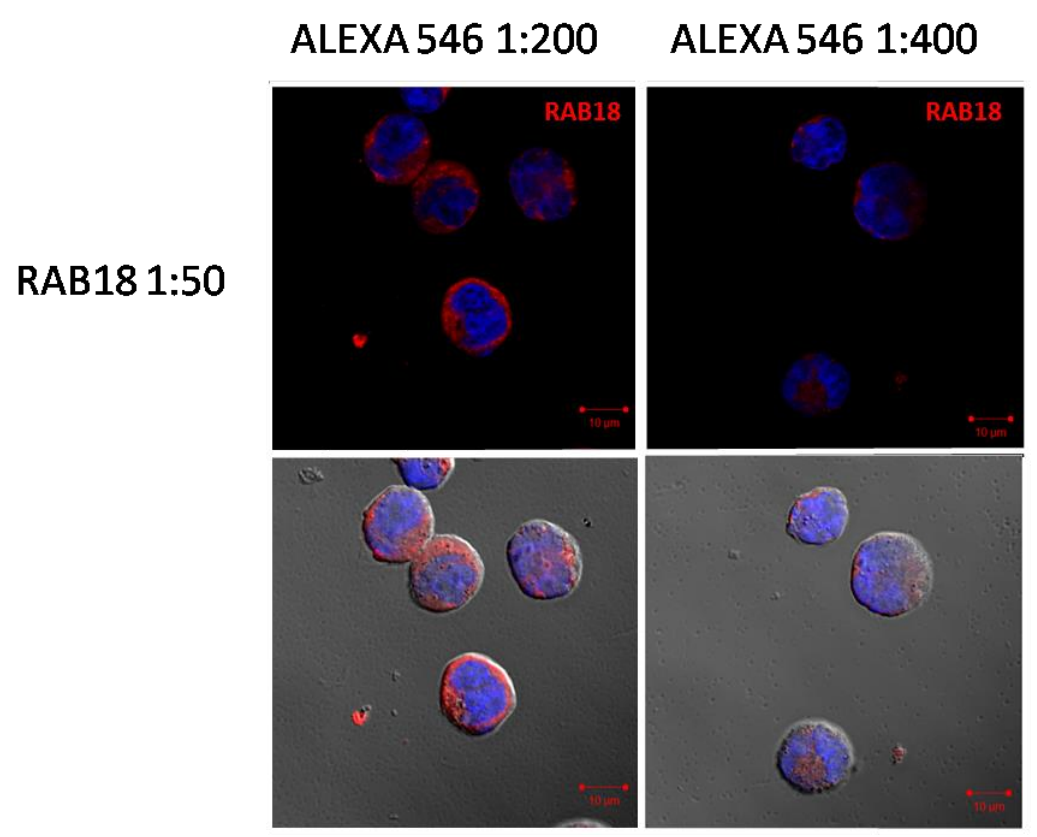

Figura 15- Padronização do anticorpo RAB18 na proporção 1:50 para identificação dessa proteína em células YT observada por microscopia confocal de fluorescência. Identificação de RAB18 com anticorpo policlonal SAB4200173 (Sigma, MO, USA) detectado com anticorpo secundário anti-IgG de coelho conjugado com AlexaFluor 546 A100400 (Invitrogen, New York, USA) nas proporções 1:200 e 1:400. Marcação de núcleo com Hoechst. Aumento de 40 x.

A padronização dos anticorpos de componentes dos grânulos citotóxicos LAMP-1, LAMP-2, perforina e granzima B foram omitidas deste estudo. Os resultados dessas padronizações demonstraram que as concentrações ideais para se trabalhar com LAMP-1 foi 1:40, LAMP-2 foi 1:50, perforina 1:15 e granzima B 1:100, enquanto que o anticorpo secundário foi 1:200 para todos esses. Estabelecemos também que as concentrações ideais para trabalhar com Tubulina e Faloidina são 1:50 e 1:800, respectivamente, a fim de avaliar se existe interação entre as proteínas alvo deste estudo e componentes do citoesqueleto celular.

Os dados das padronizações indicam a presença de todas as RABs analisadas nas células YT. Entretanto, análises mais detalhadas baseadas na colocalização das RABs com moléculas da superfície dos lisossomos (LAMP-1 e LAMP-2) e moléculas do lúmen (granzima B e perforina), forneceram informações mais precisas acerca da localização subcelular dessas proteínas. Imagens representativas dessas análises podem ser encontradas mais adiante. 
3.4 Ensaios de microscopia confocal para detecção de RAB5A e marcadores de lisossomos

Os resultados da imunomarcação para colocalização da proteína RAB5A e LAMP-1, perforina, granzima B, F-actina e tubulina, respectivamente, podem ser encontrados no painel a seguir (figura 16) e os controles do experimento em seguida na figura 17.
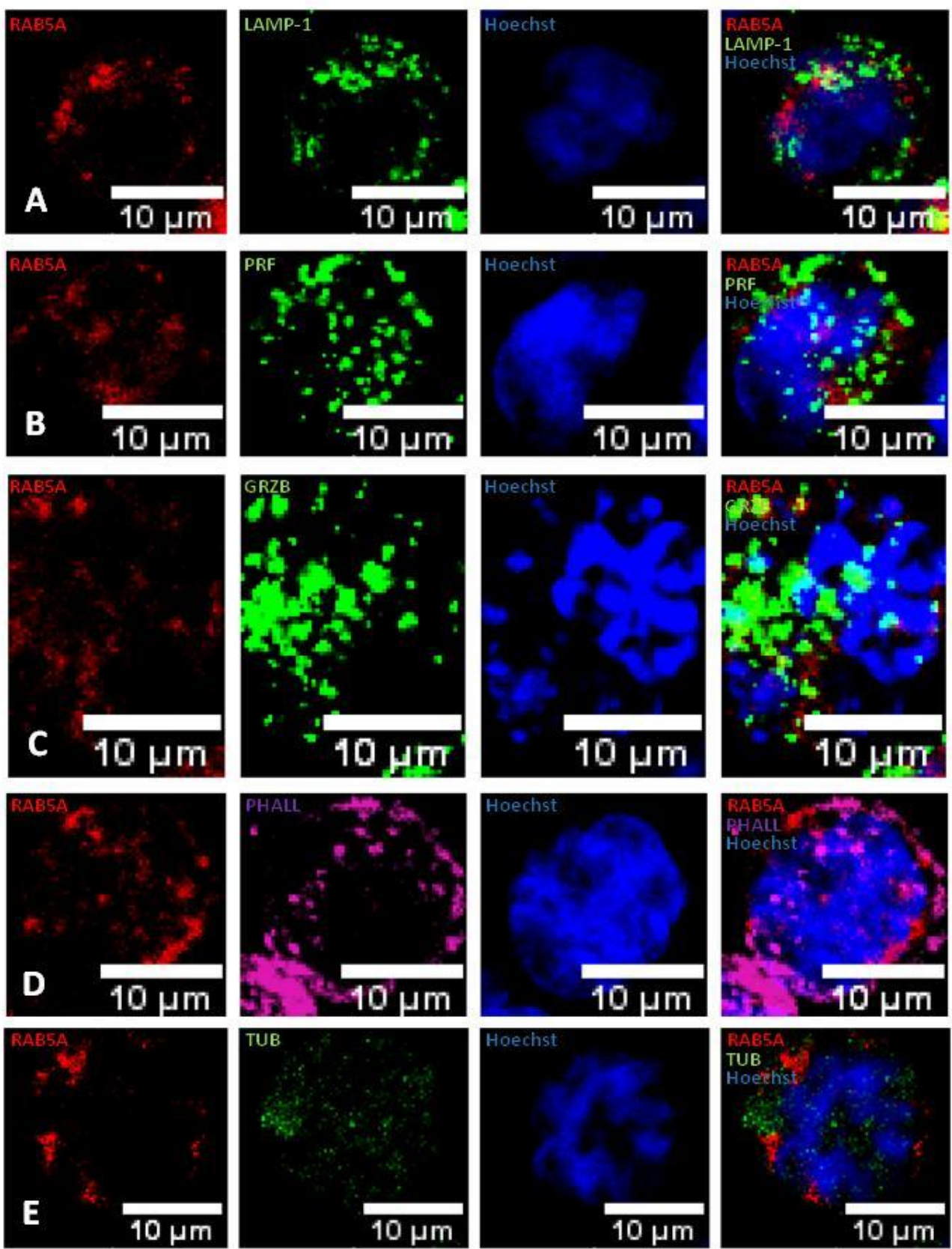

Figura 16 - Análises de microscopia confocal revelam a presença da RAB5A em uma linhagem celular humana de células NK. Um anticorpo monoclonal produzido em coelho foi utilizado para marcar RAB5A (AB109534 (Abcam, Cambridge, UK). A proteína RAB5A foi revelada utilizando um anticorpo secundário produzido em cabra e conjugado com o fluorocromo AlexaFluor 546 A100400 (Invitrogen, New York, USA). Em A podemos observar que não há colocalização de RAB5A com um anticorpo monoclonal contra a proteína de membrana de lisossomos LAMP-1 Ab25630 (Abcam, Cambridge, UK) detectado com anticorpo secundário anti-mouse conjugado com AlexaFluor 488 A-11001 (Invitrogen, New York, USA). Em B podemos observar que não há colocalização de RAB5A com um anticorpo monoclonal contra a proteína do lúmen de lisossomos perforina ab47224 (Abcam, Cambridge, UK) detectado com anticorpo secundário anti-mouse conjugado com AlexaFluor 
488 A-11001 (Invitrogen, New York, USA). Em C podemos observar que não há colocalização de RAB5A com um anticorpo monoclonal contra a proteína do lúmen de lisossomos granzima B ab10912 (Abcam, Cambridge, UK) detectado com anticorpo secundário anti-mouse conjugado com AlexaFluor 488 A-11001 (Invitrogen, New York, USA). Em D podemos observar que não há colocalização de RAB5A com um anticorpo monoclonal contra a proteína F-actinarevelada com Faloidina conjugada com fluorocromo AlexaFluor 633 A22284 (Invitrogen, Payslei, UK). Em E podemos observar que não há colocalização de RAB5A com um anticorpo monoclonal contra a proteína tubulinasc-5286 (Santa Cruz, CA, USA) detectado com anticorpo secundário anti-mouse conjugado com AlexaFluor 488 A-11001 (Invitrogen, New York, USA) Núcleo corado com Hoechst. Aumento de $40 \mathrm{x}$. Imagens realizadas utilizando o microscópio confocal de varredura a laser Zeiss LSM 510Meta.

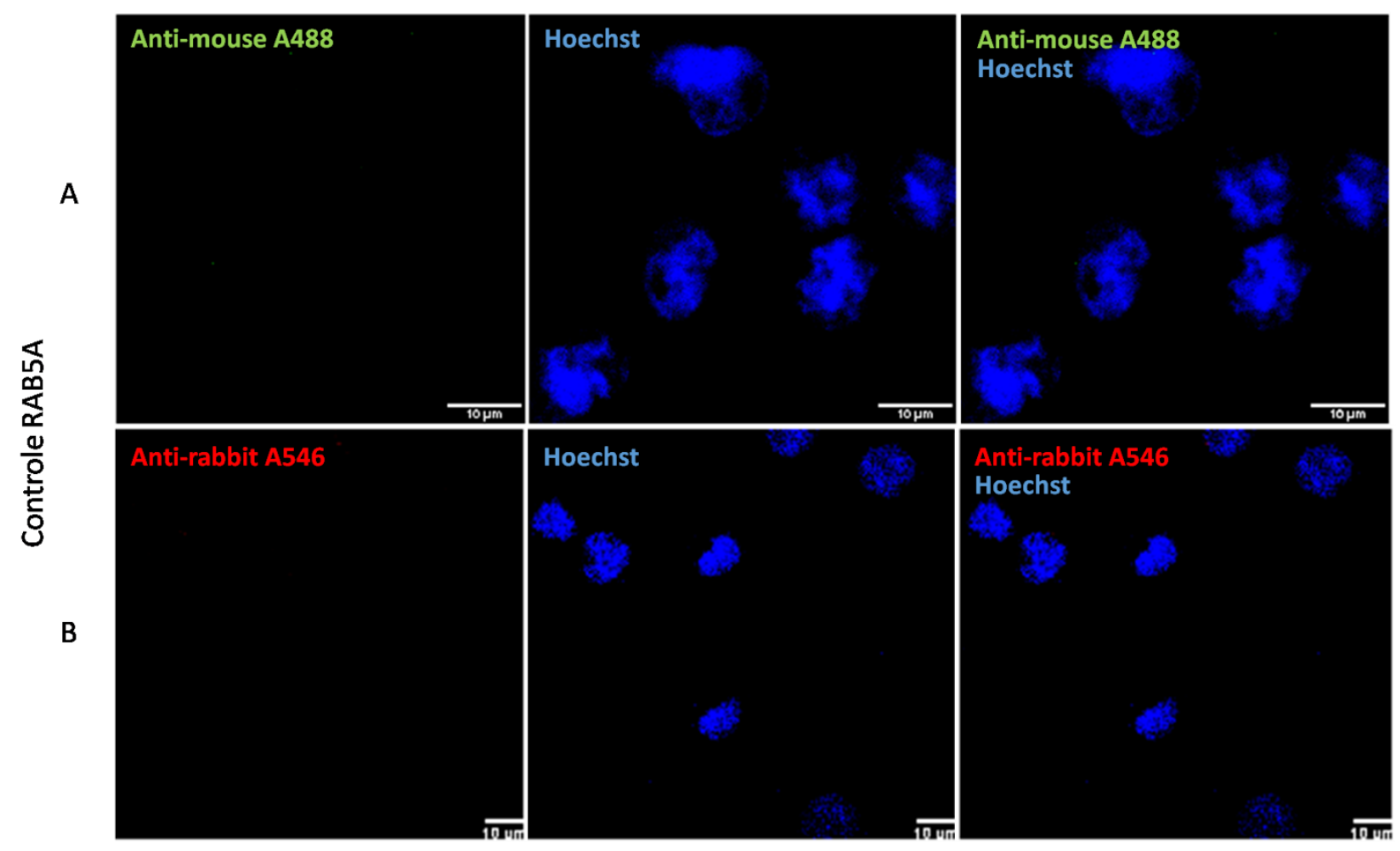

Figura 17 - Células YT incubadas com anticorpos secundários conjugados com fluorocromos na ausência de anticorpo antiRAB5A para avaliação de marcação inespecífica. Em A podemos observar a ausência de marcação inespecífica em células YT incubadas com anticorpo secundário anti-mouse conjugado com AlexaFluor 488 A-11001 (Invitrogen, New York, USA). Em B podemos observar a ausência de marcação inespecífica em células YT incubadas com anticorpo secundário anti-rabbit conjugado comfluorocromo AlexaFluor 546 A100400 (Invitrogen, New York, USA). Núcleo corado com Hoechst 62249 (Invitrogen, New York, USA). Aumento de 40 x. Imagens realizadas utilizando o microscópio confocal de varredura a laser Zeiss LSM 510-Meta.

A análise por microscopia confocal da proteína RAB5A revelou que a mesma provavelmente não está presente nos grânulos citotóxicos das células YT. As imagens da colocalização da RAB5A com LAMP-2 não ficaram satisfatórias e por isso foram eliminadas deste manuscrito. A análise das imagens em conjunto nos leva a crer que a RAB5A não está presente nos grânulos. Entretanto, confirmamos a existência dessa proteína nas células YT, provavelmente associada aoutro compartimento celular. 
3.5 Ensaios de microscopia confocal para detecção de RAB17 e marcadores de lisossomos

Os resultados da imunomarcação para colocalização da proteína RAB17 e LAMP-1, LAMP-2, perforina e granzima B, respectivamente, podem ser encontrados no painel a seguir (figura 18) e os controles do experimento em seguida na figura 19.
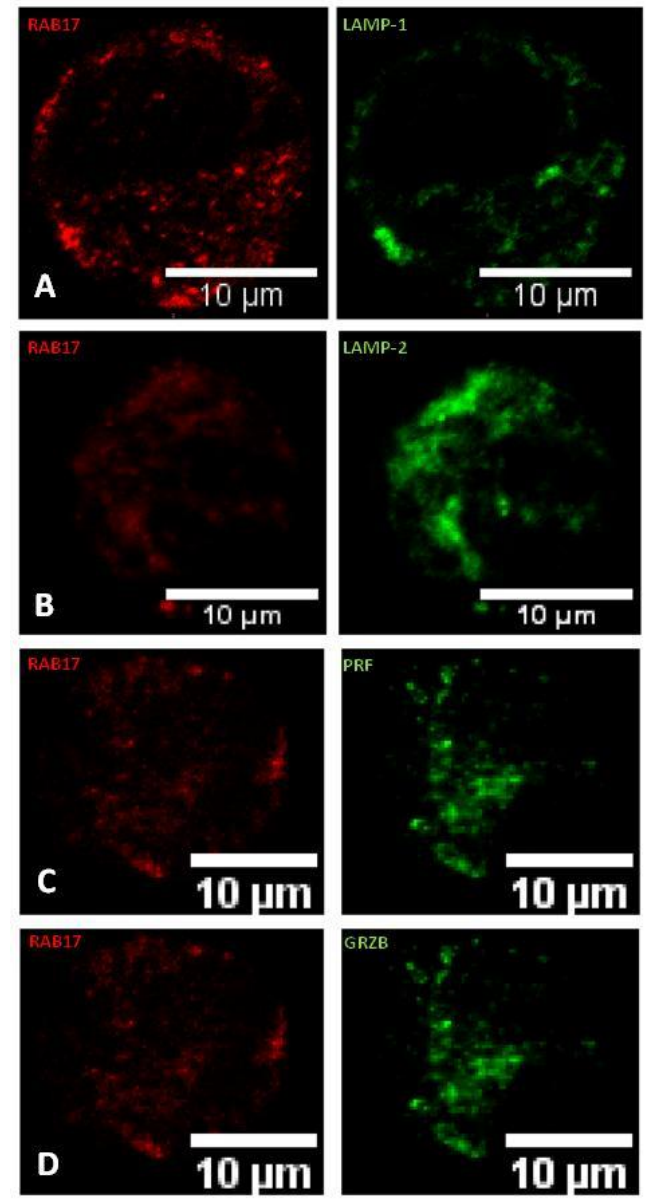
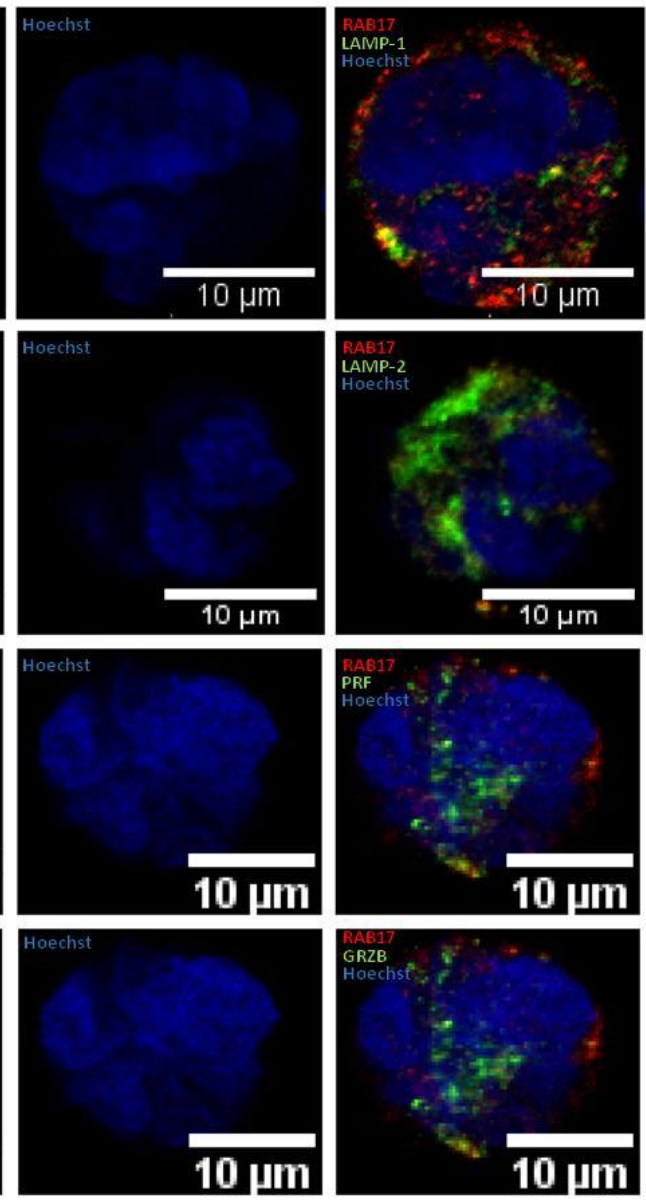

Figura 18 - Análises de microscopia confocal revelam a presença da RAB17 em grânulos citotóxicos de uma linhagem celular humana de células NK. Um anticorpo policlonal produzido em cabra foi utilizado para marcar RAB17 ab-77437 (Abcam, Cambridge, UK). A proteína RAB17 foi revelada utilizando um anticorpo secundário produzido em coelho e conjugado com o fluorocromo AlexaFluor 546 (A100400 - Invitrogen, New York, USA). Em A podemos observar que não há colocalização de RAB17 com um anticorpo monoclonal contra a proteína de membrana de lisossomos LAMP-1 Ab25630 (Abcam, Cambridge, UK) detectado com anticorpo secundário anti-mouse conjugado com AlexaFluor 488 A-11001 (Invitrogen, New York, USA). Em B podemos observar que não há colocalização de RAB17 com um anticorpo monoclonal contra a proteína de membrana de lisossomos LAMP-2 Ab25631 (Abcam, Cambridge, UK) detectado com anticorpo secundário anti-mouse conjugado com AlexaFluor 488 A-11001 (Invitrogen, New York, USA). Em C podemos observar que não há colocalização de RAB17 com um anticorpo monoclonal contra a proteína do lúmen de lisossomos perforina ab47224 (Abcam, Cambridge, UK) detectado com anticorpo secundário anti-mouse conjugado com AlexaFluor 488 A-11001 (Invitrogen, New York, USA). Em D podemos observar que não há colocalização de RAB17 com um anticorpo monoclonal contra a proteína do lúmen de lisossomos granzima B ab10912 (Abcam, Cambridge, UK) detectado com anticorpo secundário anti-mouse conjugado com AlexaFluor 488 A-11001 (Invitrogen, New York, USA). Núcleo corado com Hoechst. Aumento de 40 x. Imagens realizadas utilizando o microscópio confocal de varredura a laser Zeiss LSM 510-Meta. 


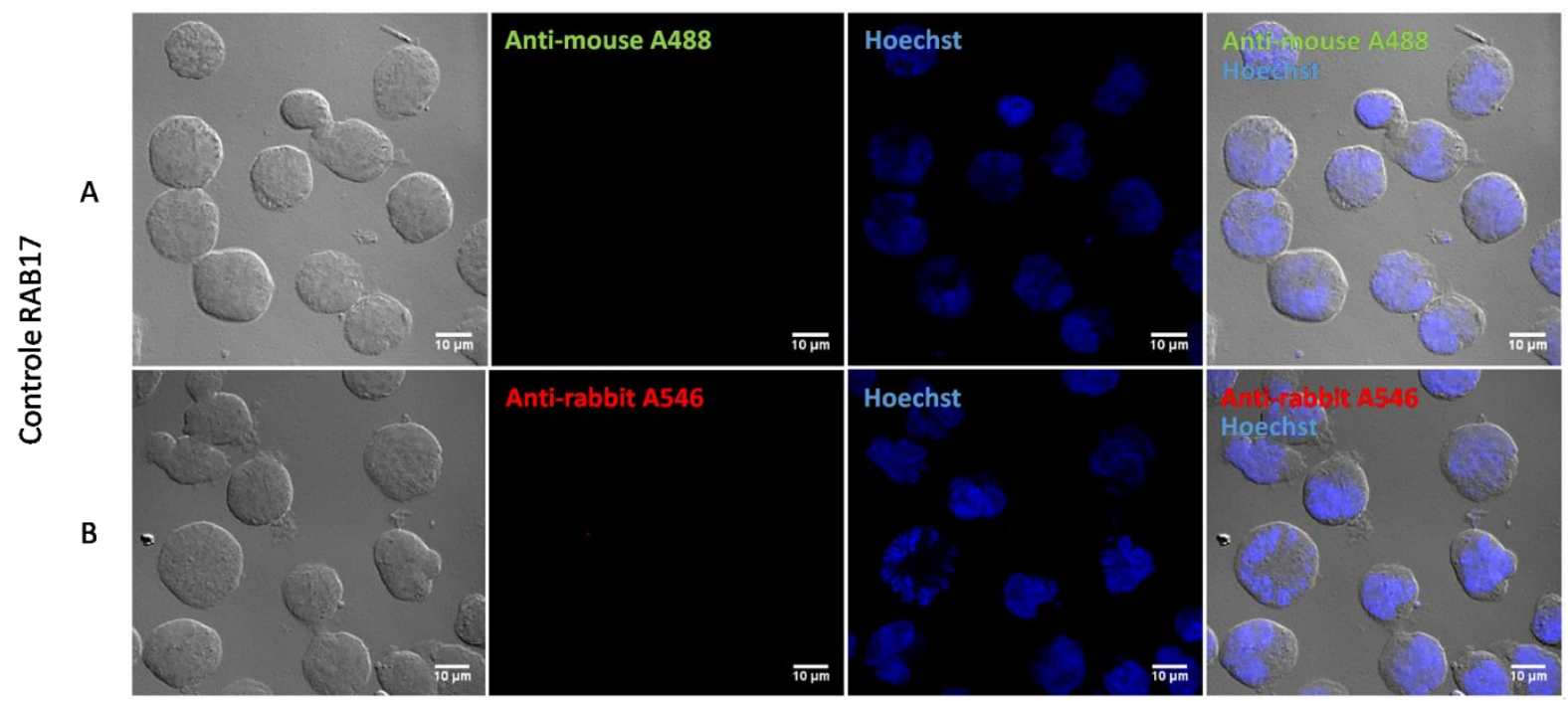

Figura 19 - Células YT incubadas com anticorpos secundários conjugados com fluorocromos na ausência de anticorpo antiRAB17 para avaliação de marcação inespecífica. Em A podemos observar a ausência de marcação inespecífica em células YT incubadas com anticorpo secundário anti-mouse conjugado com AlexaFluor 488 A-11001 (Invitrogen, New York, USA). Em B podemos observar a ausência de marcação inespecífica em células YT incubadas com anticorpo secundário anti-rabbit conjugado comfluorocromo AlexaFluor 546 A100400 (Invitrogen, New York, USA). Núcleo corado com Hoechst 62249 (Invitrogen, New York, USA). Aumento de 40 x. Imagens realizadas utilizando o microscópio confocal de varredura a laser Zeiss LSM 510-Meta.

A análise dos resultados obtidos a partir da imunomarcação da RAB17 e LAMP-1, LAMP-2, granzima B e perforina por microscopia confocal de fluorescência nos permitiu concluir que esta proteína está presente nas células YT, porém, não está presente nos grânulos citotóxicos dessa linhagem celular. Mais uma vez tratamos isso como fruto de contaminação da proteômica, provavelmente devido a fragmentos de membrana de outras organelas presentes no material analisado.

3.6 Ensaios de microscopia confocal para detecção de RAB18 e marcadores de lisossomos

Os resultados da imunomarcação para colocalização da proteína RAB18 e LAMP-1, LAMP-2, perforina, granzima B e F-actina, respectivamente, podem ser encontrados no painel a seguir (figura 20) e os controles do experimento em seguida na figura 21. 

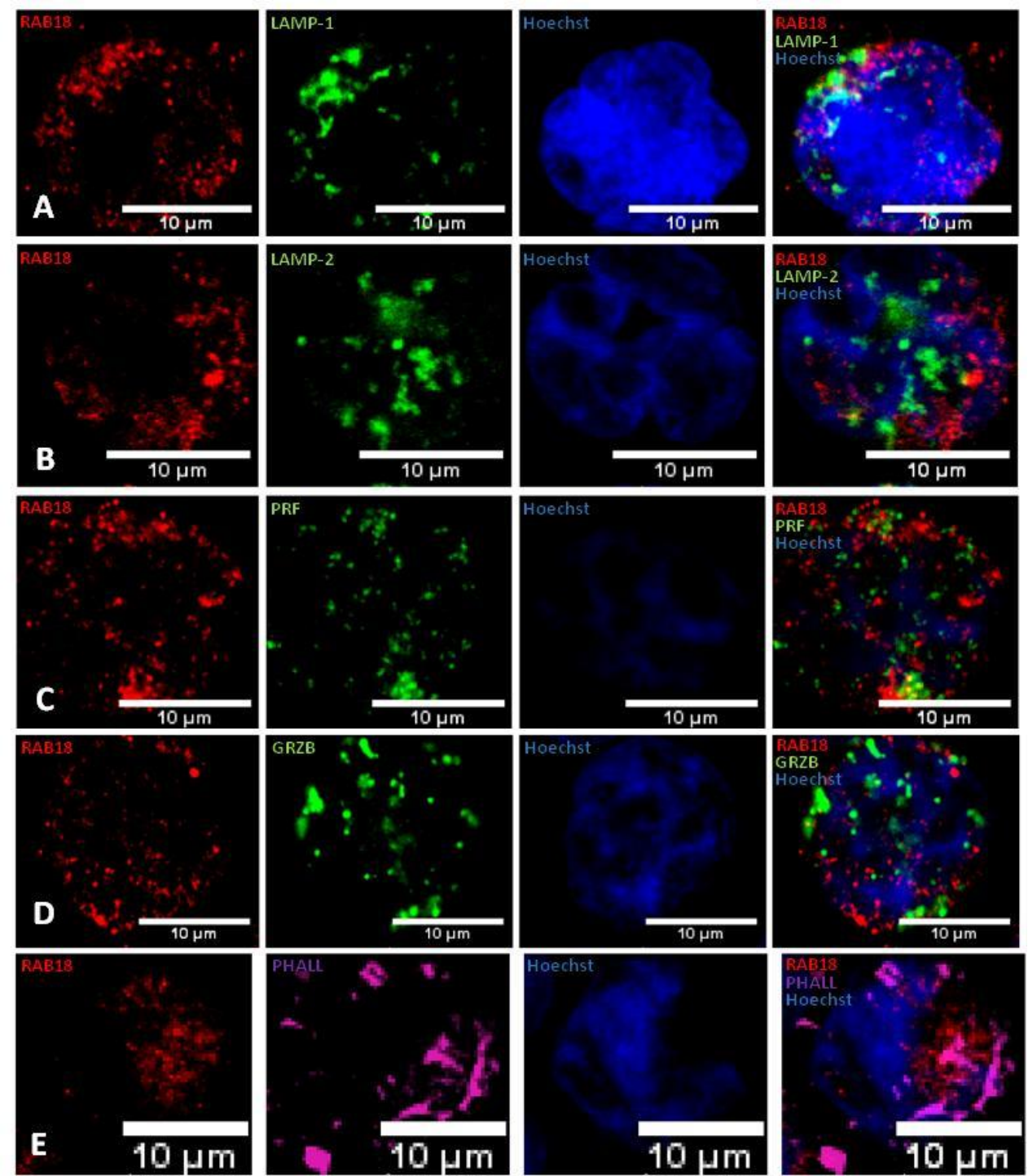

Figura 20 - Análises de microscopia confocal revelam a presença da RAB18 em grânulos citotóxicos de uma linhagem celular humana de células NK. Um anticorpo policlonal produzido em coelho foi utilizado para marcar RAB18 SAB4200173 (Sigma, MO, USA). A proteína RAB18 foi revelada utilizando um anticorpo secundário produzido em cabra e conjugado com o fluorocromo AlexaFluor 546 A100400 (Invitrogen, New York, USA). Em A podemos observar que não há colocalização de RAB18 com um anticorpo monoclonal contra a proteína de membrana de lisossomos LAMP-1 Ab25630 (Abcam, Cambridge, UK) detectado com anticorpo secundário anti-mouse conjugado com AlexaFluor 488 A-11001 (Invitrogen, New York, USA). Em B podemos observar que não há colocalização de RAB18 com um anticorpo monoclonal contra a proteína de membrana de lisossomos LAMP-2 Ab25631 (Abcam, Cambridge, UK) detectado com anticorpo secundário anti-mouse conjugado com AlexaFluor 488 A-11001 (Invitrogen, New York, USA). Em C podemos observar que não há colocalização de RAB18 com um anticorpo monoclonal contra a proteína do lúmen de lisossomos perforina ab47224 (Abcam, Cambridge, UK) detectado com anticorpo secundário anti-mouse conjugado com AlexaFluor 488 A-11001 (Invitrogen, New York, USA). Em D podemos observar que não há colocalização de RAB18 com um anticorpo monoclonal contra a proteína do lúmen de lisossomos granzima B ab10912 (Abcam, Cambridge, UK) detectado com anticorpo secundário anti-mouse conjugado com AlexaFluor 488 A-11001 (Invitrogen, New York, USA). Em E podemos observar que não há colocalização de RAB18 com um anticorpo monoclonal contra a proteína F-actina revelada com Faloidina conjugada com fluorocromo AlexaFluor 633 A22284 (Invitrogen, Payslei, UK). Núcleo corado com Hoechst. Aumento de 40 x. Imagens realizadas utilizando o microscópio confocal de varredura a laser Zeiss LSM 510-Meta. 


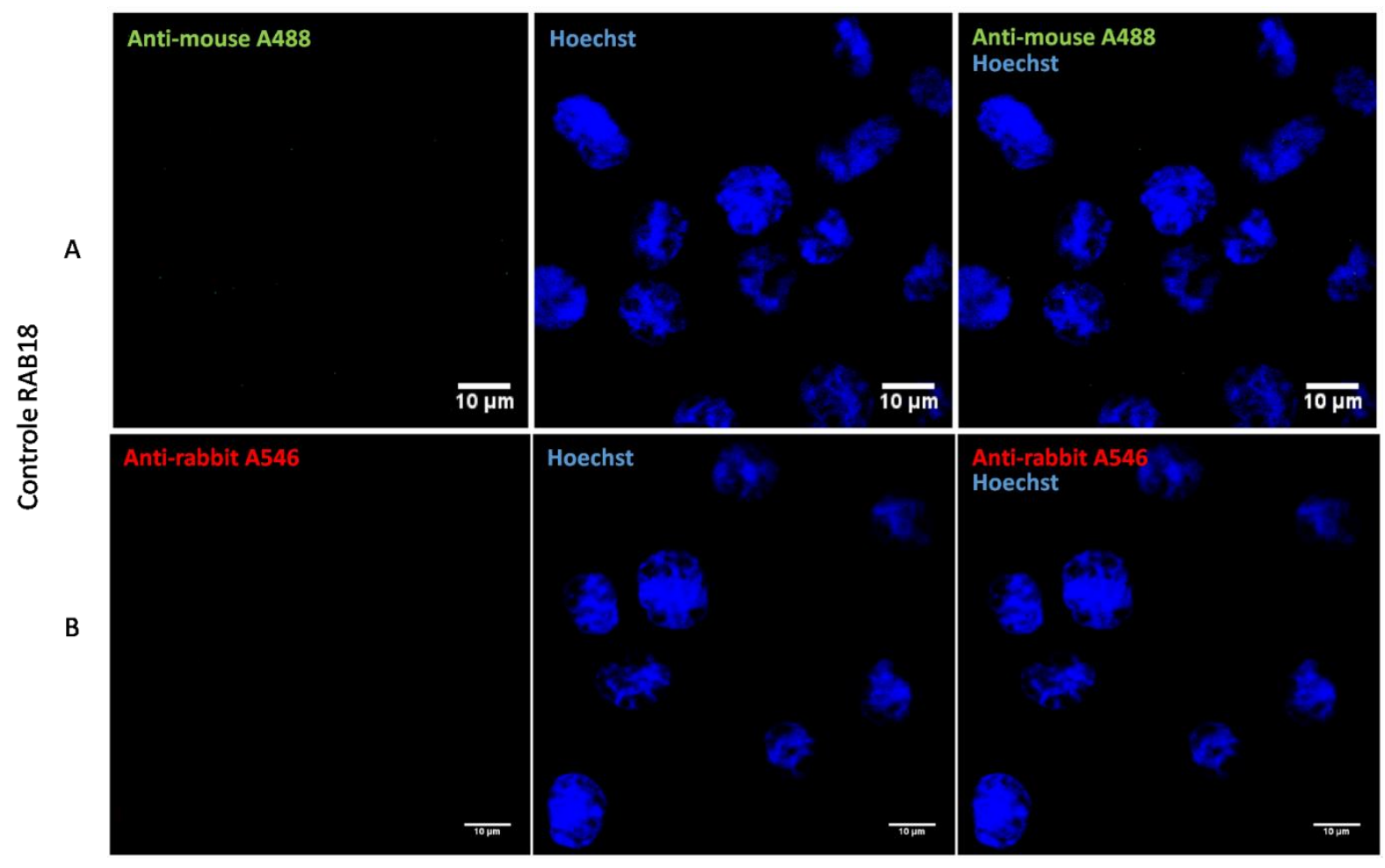

Figura 21 - Células YT incubadas com anticorpos secundários conjugados com fluorocromos na ausência de anticorpo antiRAB18 para avaliação de marcação inespecífica. Em A podemos observar a ausência de marcação inespecífica em células YT incubadas com anticorpo secundário anti-mouse conjugado com AlexaFluor 488 A-11001 (Invitrogen, New York, USA). Em B podemos observar a ausência de marcação inespecífica em células YT incubadas com anticorpo secundário anti-rabbit conjugado comfluorocromo AlexaFluor 546 A100400 (Invitrogen, New York, USA). Núcleo corado com Hoechst 62249 (Invitrogen, New York, USA). Aumento de 40 x. Imagens realizadas utilizando o microscópio confocal de varredura a laser Zeiss LSM 510-Meta.

Assim como aconteceu com os experimentos utilizando anticorpos para RAB5A e RAB17, a presença da RAB18 na análise de proteômica foi considerada um artefato da técnica de separação celular utilizada nos experimentos que deram origem a este projeto. Novamente confirmamos a presença desta proteína nas células YT, porém, provavelmente em um contexto diferente do que está sendo abordado neste estudo.

3.7 Ensaios de microscopia confocal para detecção de RAB2A e marcadores de lisossomos

As imagens com o resultado da análise de microscopia confocal a fim de evidenciar colocalização da RAB2A e LAMP-1, RAB2A e LAMP-2, RAB2A e perforina, e RAB2A e granzima $B$ podem ser vistas nas figuras 22, 23, 24 e 25, respectivamente, bem como um painel representativo desses experimentos (figura 26)e o controle dos experimentos (figura 27). 

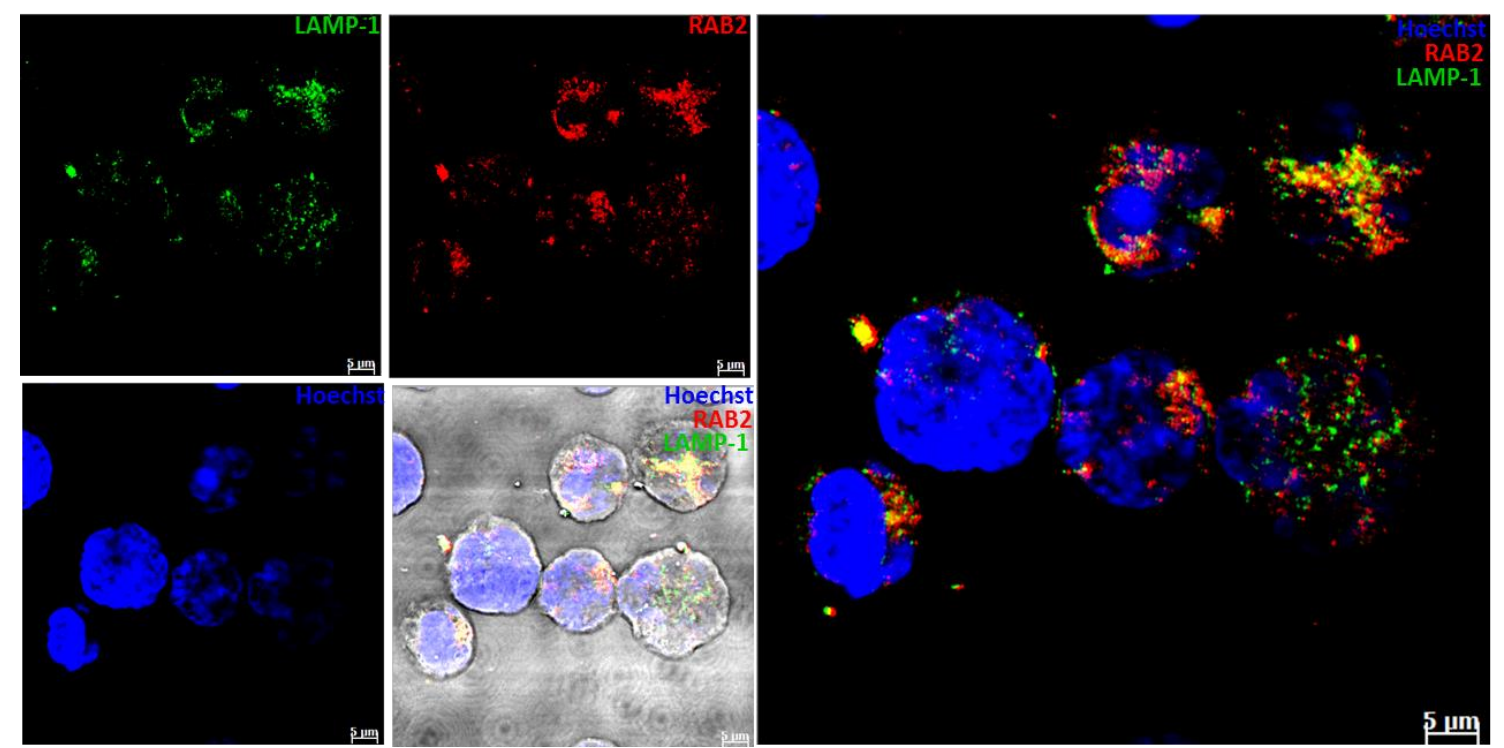

Figura 22- Colocalização de RAB2A e LAMP-1 em células YT observada por microscopia confocal de fluorescência. Identificação de RAB2A com anticorpo policlonalsc-26547 (Santa Cruz, CA, USA) detectado com anticorpo secundário antiIgG de cabra conjugado com AlexaFluor 546 A11056 (Invitrogen, New York, USA); Identificação de LAMP-1 Ab25630 (Abcam, Cambridge, UK) com anticorpo monoclonal detectado com anticorpo secundário anti-mouse conjugado com AlexaFluor 488 A-11001 (Invitrogen, New York, USA) e marcação de núcleo com Hoechst. Aumento de 40 x.
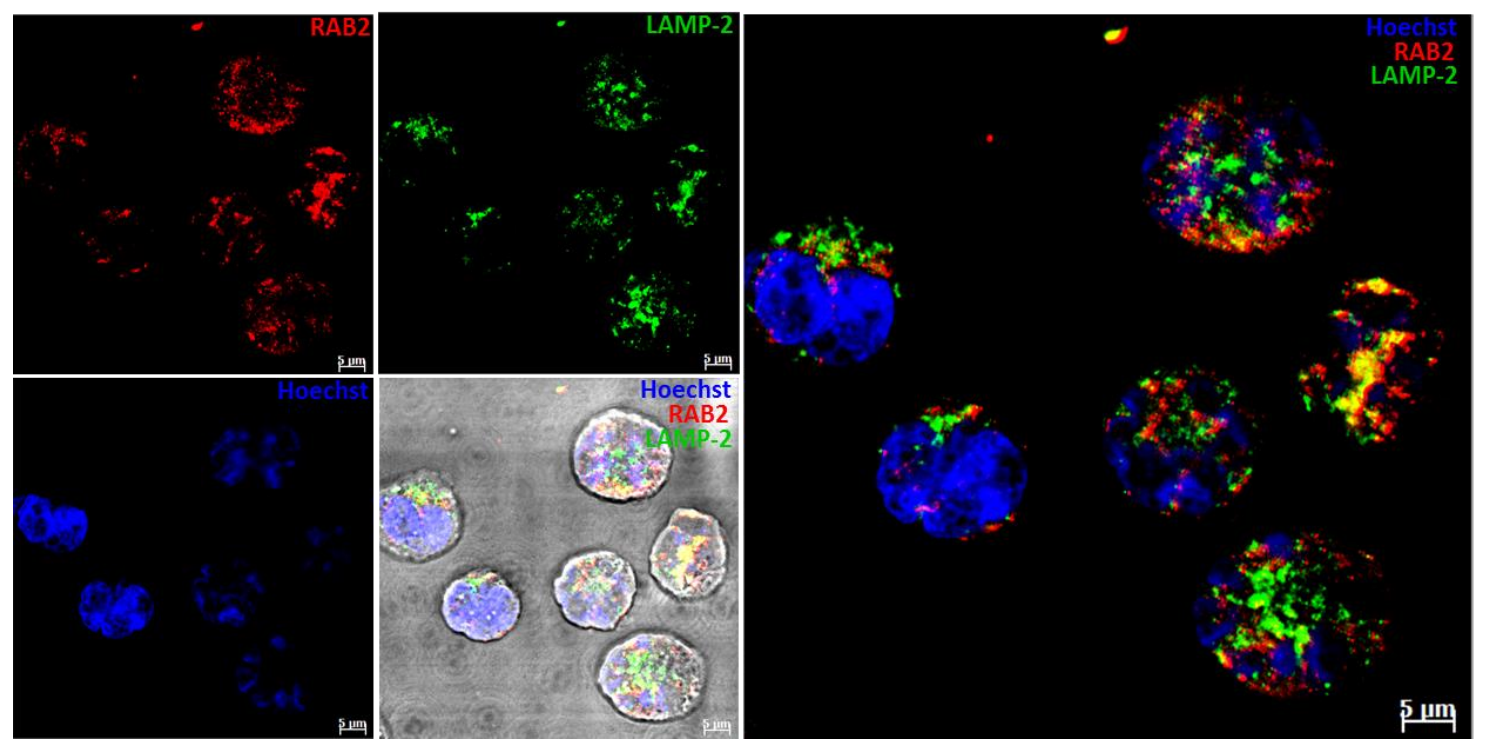

Figura 23 - Colocalização de RAB2A e LAMP-2 em lisossomos de células YT observada por microscopia confocal de fluorescência. Identificação de RAB2A com anticorpo policlonalsc-26547 (Santa Cruz, CA, USA) detectado com anticorpo secundário anti-IgG de cabra conjugado com AlexaFluor 546 A11056 (Invitrogen, New York, USA); Identificação de LAMP-2 com anticorpo monoclonal Ab25631 (Abcam, Cambridge, UK) detectado com anticorpo secundário anti-mouse conjugado com AlexaFluor488 A-11001 (Invitrogen, New York, USA) e marcação de núcleo com Hoechst. Aumento de 40 x. 


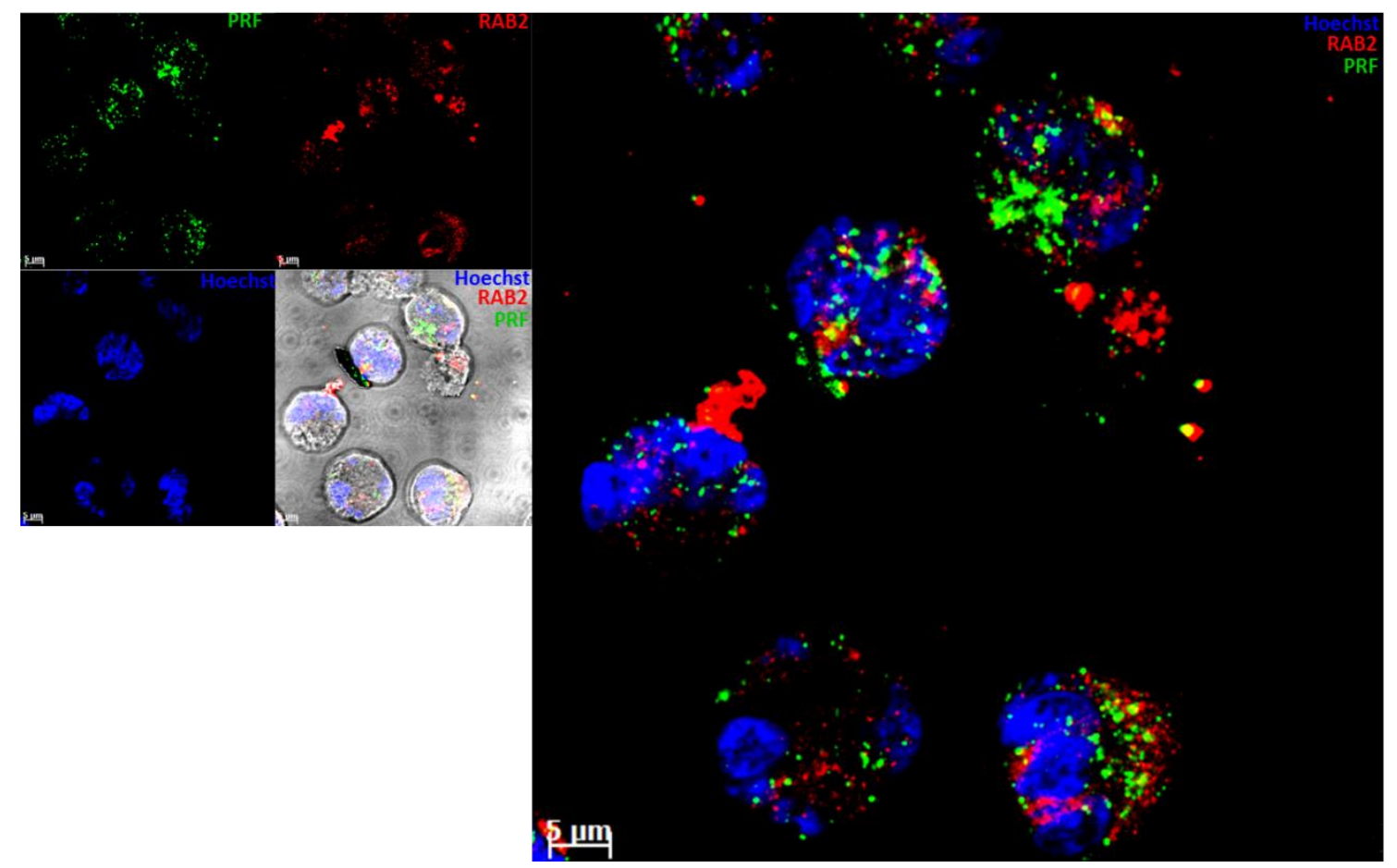

Figura 24 - Colocalização de RAB2A e Perforina em lisossomos de células YT observada por microscopia confocal de fluorescência. Identificação de RAB2A com anticorpo policlonalsc-26547 (Santa Cruz, CA, USA) detectado com anticorpo secundário anti-IgG de cabra conjugado com AlexaFluor 546 A11056 (Invitrogen, New York, USA); Identificação de Perforina com anticorpo monoclonal ab47224 (Abcam, Cambridge, UK) detectado com anticorpo secundário anti-mouse conjugado com AlexaFluor 488 A-11001 (Invitrogen, New York, USA) e marcação de núcleo com Hoechst. Aumento de 40 x.
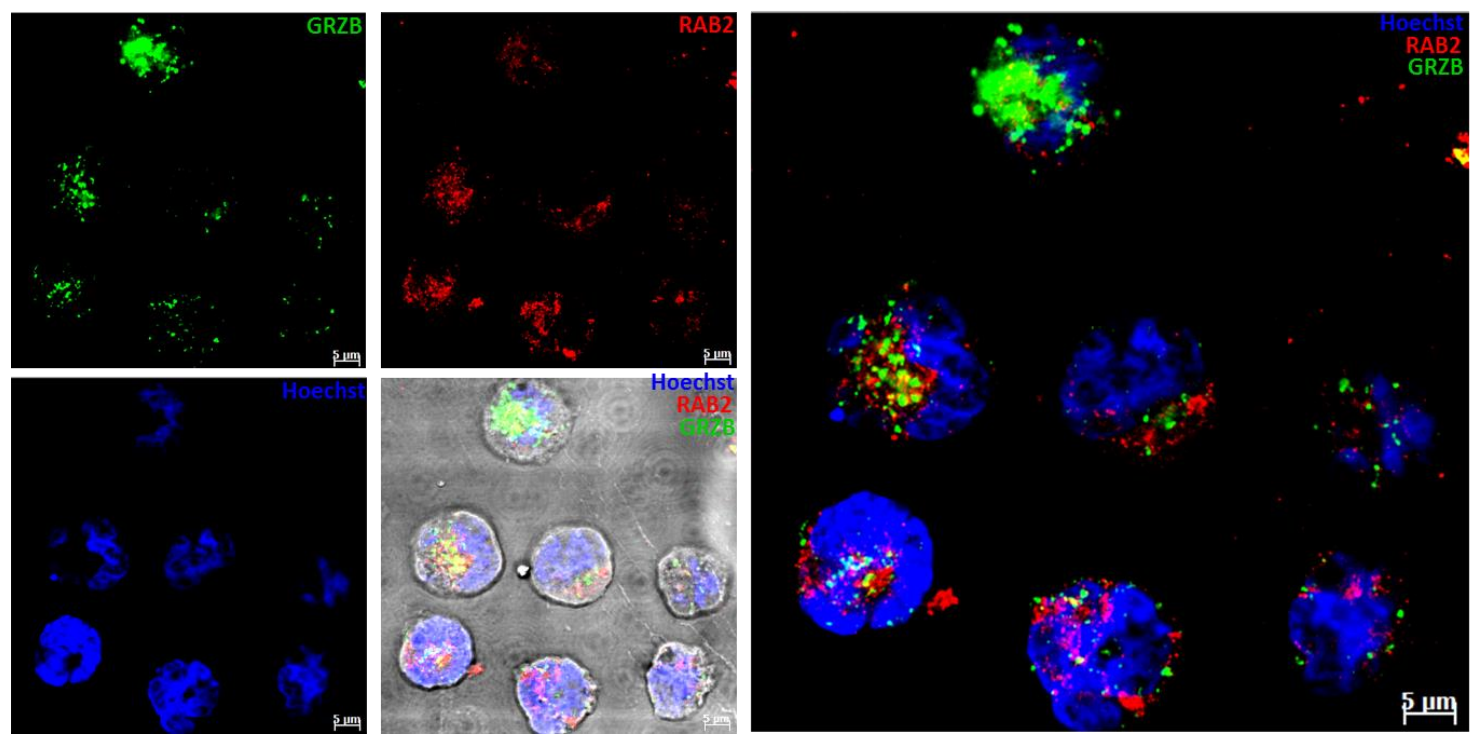

Figura 25-Colocalização de RAB2A e Granzima B em lisossomos de células YT observada por microscopia confocal de fluorescência. Identificação de RAB2A com anticorpo policlonalsc-26547 (Santa Cruz, CA, USA) detectado com anticorpo secundário anti-IgG de cabra conjugado com AlexaFluor 546 A11056 (Invitrogen, New York, USA); Identificação de Granzima B com anticorpo monoclonal ab10912 (Abcam, Cambridge, UK) detectado com anticorpo secundário anti-mouse conjugado com AlexaFluor 488 A-11001 (Invitrogen, New York, USA) e marcação de núcleo com Hoechst. Aumento de 40 x. 

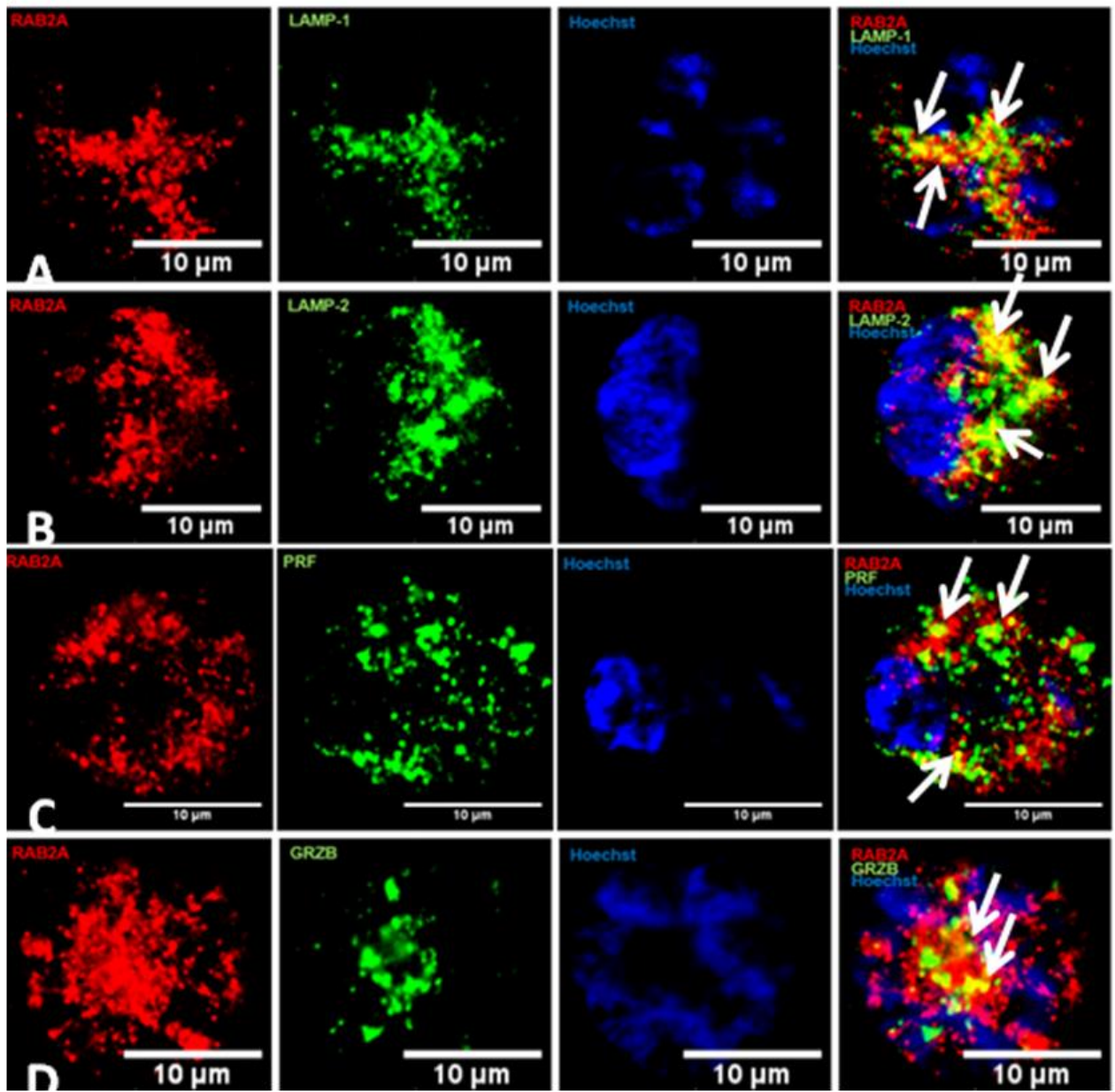

Figura 26 - Análises de microscopia confocal revelam a presença da RAB2A em grânulos citotóxicos de uma linhagem celular humana de células NK. Um anticorpo policlonal produzido em cabra foi utilizado para marcar RAB2A (sc-26547 - Santa Cruz, CA, USA). A proteína RAB2A foi revelada utilizando um anticorpo secundário produzido em coelho e conjugado com o fluorocromo AlexaFluor 546 (A100400 - Invitrogen, New York, USA). Em A podemos observar a colocalização de RAB2A com um anticorpo monoclonal contra a proteína de membrana de lisossomos LAMP-1 Ab25630 (Abcam, Cambridge, UK)detectado com anticorpo secundário anti-mouse conjugado com AlexaFluor 488 A-11001 (Invitrogen, New York, USA). Em B podemos observar a colocalização de RAB2A com um anticorpo monoclonal contra a proteína de membrana de lisossomos LAMP-2 Ab25631 (Abcam, Cambridge, UK) detectado com anticorpo secundário anti-mouse conjugado com AlexaFluor 488 A-11001 (Invitrogen, New York, USA). Em C podemos observar a colocalização de RAB2A com um anticorpo monoclonal contra a proteína do lúmen de lisossomos perforinaab47224 (Abcam, Cambridge, UK) detectado com anticorpo secundário anti-mouse conjugado com AlexaFluor 488 A-11001 (Invitrogen, New York, USA). Em D podemos observar a colocalização de RAB2A com um anticorpo monoclonal contra a proteína do lúmen de lisossomos granzima B ab10912 (Abcam, Cambridge, UK) detectado com anticorpo secundário anti-mouse conjugado com AlexaFluor 488 A-11001 (Invitrogen, New York, USA). Núcleo corado com Hoechst. Aumento de 40 x. Imagens realizadas utilizando o microscópio confocal de varredura a laser Zeiss LSM 510-Meta. As setas brancas indicam regiões de colocalização entre a RAB2A e a proteína indicada na análise. 


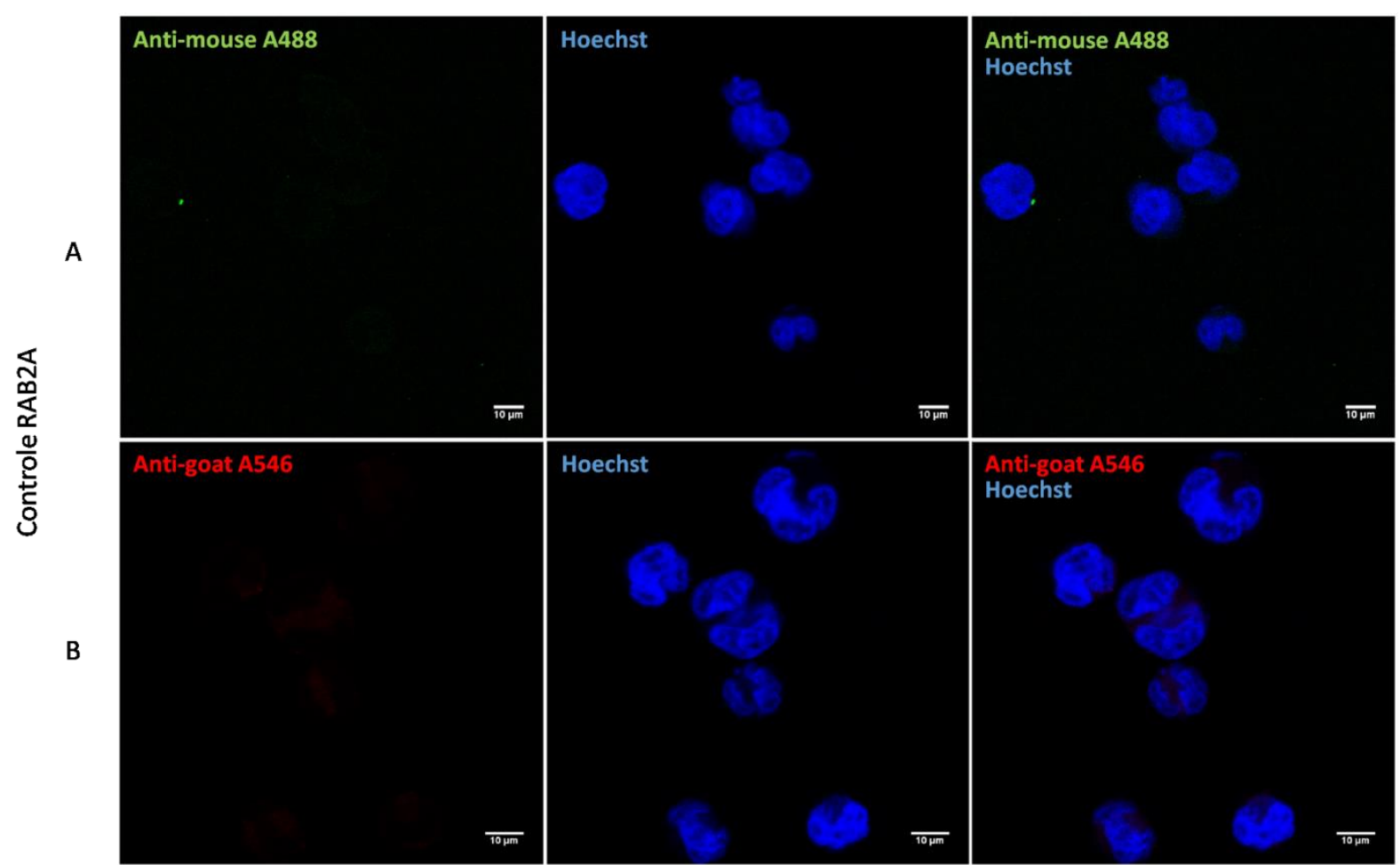

Figura 27 - Células YT incubadas com anticorpos secundários conjugados com fluorocromos na ausência de anticorpo antiRAB2A para avaliação de marcação inespecífica. Em A podemos observar a ausência de marcação inespecífica em células YT incubadas com anticorpo secundário anti-mouse conjugado com AlexaFluor 488 A-11001 (Invitrogen, New York, USA). Em B podemos observar a ausência de marcação inespecífica em células YT incubadas com anticorpo secundário anti-goat conjugado com o fluorocromo AlexaFluor 546 A11056 (Invitrogen, New York, USA). Núcleo corado com Hoechst 62249 (Invitrogen, New York, USA). Aumento de 40 x. Imagens realizadas utilizando o microscópio confocal de varredura a laser Zeiss LSM 510-Meta.

A análise das imagens dos experimentos utilizando a marcação da proteína RAB2A e quatro diferentes proteínas presentes nos lisossomos nos leva a concluir que a RAB2A está presente nos grânulos citotóxicos da linhagem celular de células NK humanas YT, devido ao alto grau de colocalização evidenciado nas imagens. Além disso, nossos dados sugerem que a RAB2A provavelmente tenha um contato maior com as proteínas da membrana do grânulo como LAMP-1 e LAMP-2 do que com as proteínas do lúmen perforina e granzima B, um forte indício da presença da RAB2A na membrana dos grânulos e por isso foi realizada uma análise de quantificação da colocalização dessas proteínas com a RAB2A e esta pode ser vista abaixo.

3.8 Análise para quantificação da colocalização de RAB2A e LAMP-1, LAMP-2, Perforina e Granzima B 
As imagens geradas através de microscopia confocal da RAB2A foram submetidas a uma análise para quantificação da colocalização e os dados gerados foram transformados em um gráfico de barras de acordo com a figura 28.

A análise do gráfico indica uma forte colocalização da RAB2A com proteínas de membrana como LAMP-1 e LAMP-2 e uma baixa colocalização desta proteína com proteínas do lúmen dos lisossomos como perforina e granzima B.
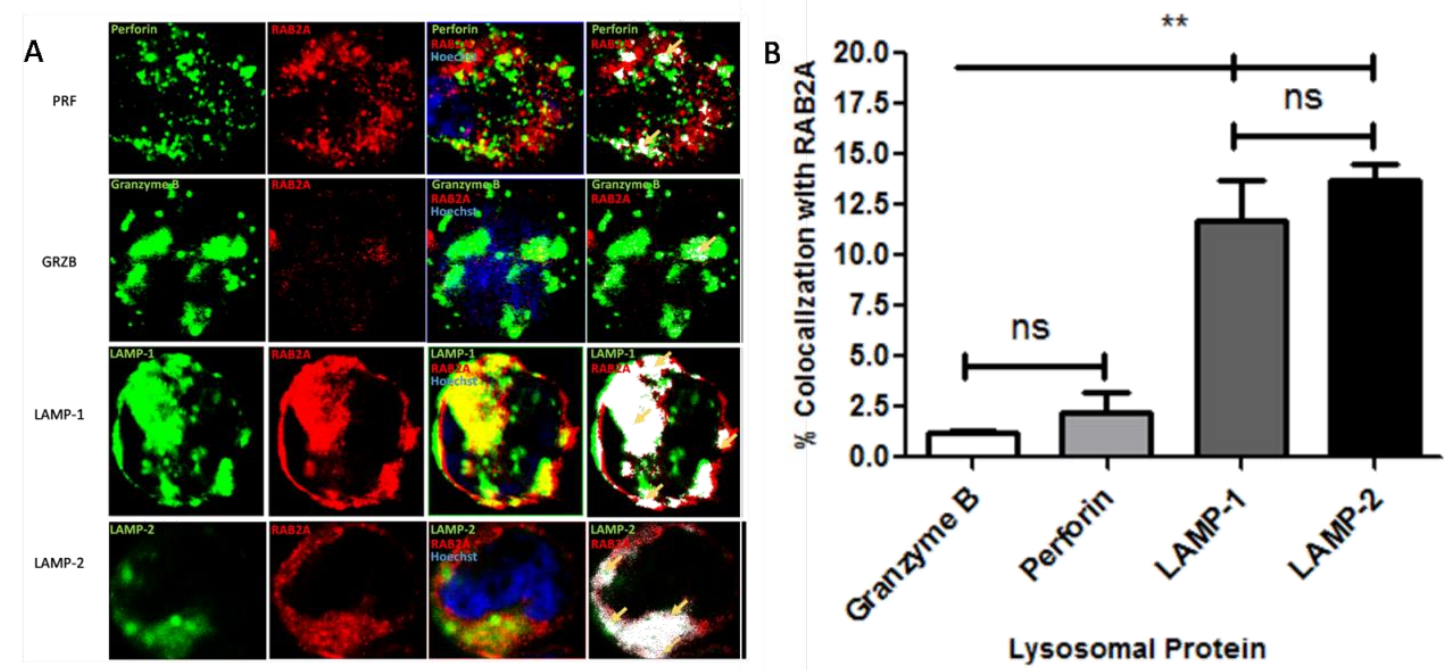

Figura 28 - Análise quantitativa da colocalização de RAB2A e os marcadores de lisossomos. (A) Imagens representativas do grau de colocalização da RAB2A com os marcadores do lúmen granzima $B$ e perforina e marcadores da membrana de lisossomos LAMP-1 e LAMP-2 foram analisados com a ferramenta de colocalização do software ImageJ. (B) Os valores obtidos foram transformados em gráficos de coluna e o nível de significância analisados com o software GraphPad Prism . A análise foi realizada em quintuplicata e encontrado o valor $P<0.05$. As setas em amarelo indicam regiões de colocalização analisadas pelo programa.

A metodologia utilizada nesta primeira fase é muito robusta e forneceu subsídios suficientes para dizer que a RAB5A, RAB17 e RAB18 não estão presentes nos grânulos citotóxicos. Entretanto, uma segunda abordagem na qual utilizamos técnicas de microscopia eletrônica de transmissão foi necessária para validação dos nossos dados acerca da localização da RAB2A

3.9 Microscopia Eletrônica de Transmissão de Células Natural Killer da Linhagem Humana YT com marcação da proteína RAB2A em grânulos citotóxicos

Uma vez que o objetivo deste projeto é o estudo das proteínas RABs nos grânulos citotóxicos, e, que somente a RAB2A foi observada nesses compartimentos utilizando microscopia confocal, o nosso foco foi mantido e por hora o estudo da RAB5A, RAB17 e 
RAB18 foi deixado de lado e toda a nossa atenção foi voltada para o estudo da RAB2A. A fim de validar os dados da proteômica e dos estudos de microscopia confocal, utilizamos a técnica padrão ouro para a determinação da localização celular de proteínas: a microscopia eletrônica de transmissão (MET).

As técnicas utilizadas no preparo das amostras para microscopia eletrônica seguem os mesmos princípios das técnicas utilizadas na microscopia de luz. Em geral, a identificação de um antígeno é precedida pela marcação com um anticorpo contra a proteína alvo do estudo e a visualização dessa proteína dá-se por meio da utilização de anticorpos secundários conjugados com metais pesados, sendo o mais comum o ouro, que refletem os elétrons incidentes. Esta técnica permite a distinção de organelas baseada na morfologia, características intrínsecas das organelas, ou por meio da utilização de anticorpos contra proteínas típicas das organelas (123).

Amarcação com anticorpos conjugados com partículas de ouro da RAB2A em células YT parece corroborar com os dados anteriores, em que se observa a marcação dessa proteína em organelas cuja forma e o padrãoeletrondenso assemelham-se a lisossomos. Além disso, podemos observar também a marcação da proteína RAB2A dispersa no citoplasma (figura 29), esta mesma característica foi observada nas microscopias confocais.

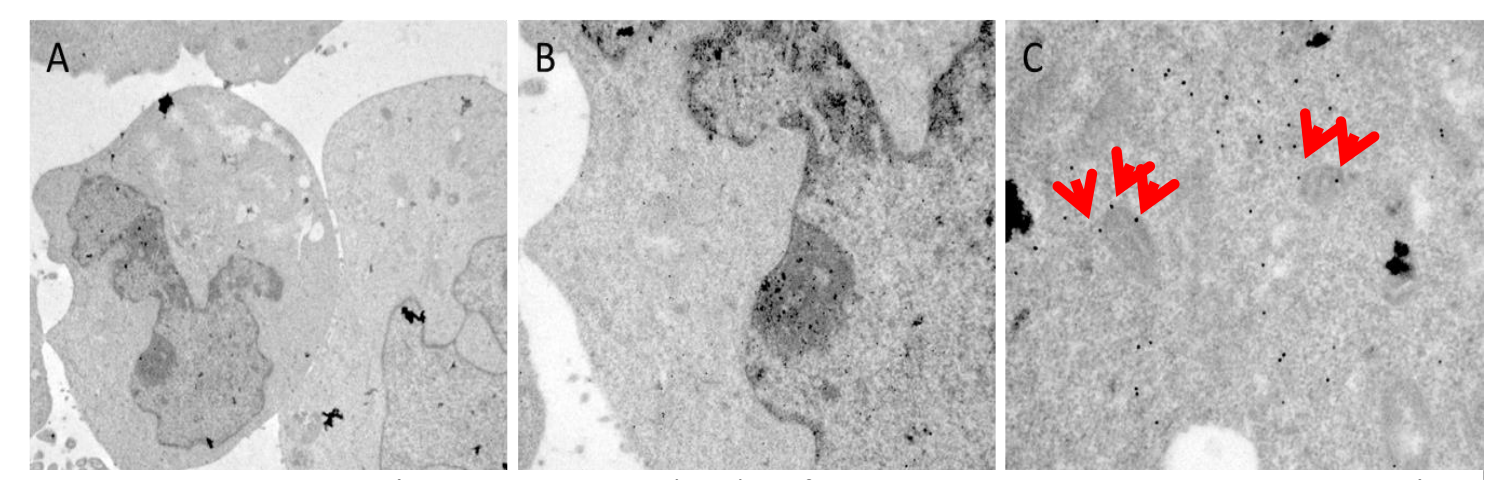

Figura 29 - Microscopia eletrônica de transmissão (MET) confirma a presença da RAB2A em lisossomos de células citotóxicas. As setas vermelhas indicam marcações para RAB2A na membrana de lisossomos.Um anticorpo antiRAB2A produzido em cabra (SAB2500850 - Sigma Aldrich)foi utilizado para marcar esta proteína que foi revelada com um anticorpo secundário conjugado com partículas de ouro de $18 \mathrm{~nm}$ produzido em burro (Jackson ImmunoResearch). Aumento de $6000 \times$ (a), $20000 \times$ (b) and $50000 \times$ (c).

Juntos, os dados de proteômica, microscopia confocal e microscopia eletrônica não deixam qualquer dúvida acerca da localização da RAB2A. Com isso, nossa conclusão até este momento é que a RAB2A está presente em grânulos citotóxicos de células YT. 
Nosso próximo passo foi investigar a função desta proteína. Para isso, desenvolvemos uma série de metodologias a fim de avaliar a função biológica da RAB2A nos grânulos citotóxicos de células citotóxicas, cujo objetivo final é comparar se existem diferenças nas funções entre células selvagens e células que sofreram o silenciamento gênico da RAB2A. Para este fim desenvolvemos um protocolo de transdução estável utilizando shRNA para células primárias murinas e fez-se necessário tambémo desenvolvimento de outra tecnologia, desta vez utilizando CRISPR/CAS9, para a transdução estável de células de linhagem humanas. Os resultados de ambos os protocolos podem ser vistos adiante.

3.10 Protocolo de transdução estável de células não aderentes utilizando lentivírus portando shRNA

Inicialmente optou-se por trabalhar com células primárias derivadas do baço de camundongos C57BI6 selvagens submetidos a um protocolo de expansão linfócitos T CD8 (protocolo desenvolvido durante o doutorado, consultar seção Materiais e Métodos) e subsequente enriquecimento por meio da adaptação de um protocolo de separação celular utilizando um kit comercial cujo princípio é a separação negativa das células de interesse com a utilização de anticorpos conjugados com pérolas magnéticas (para mais informações consultar seção Materiais e Métodos).

Após o protocolo de geração de blastos, as células foram marcadas com anticorpos contra moléculas de superfície e então fenotipadas através de citometria de fluxo para os receptores CD3, CD4 e CD8. Quanto à caracterização fenotípica das células, verificamos que houve uma frequência superior a $97 \%$ de célulasCD8 positivas entre as células positivas para CD3, e menos de $3 \%$ de linfócitos T CD4, enquanto que as células que foram removidas do baço e mantidas em cultura paralelamente ao experimento (blasto total) apresentaram uma frequência em torno de $60 \%$ de linfócitos T CD8 e um número absoluto bem menor do que o protocolo testado (dados não mostrados). Nossos dados evidenciam que o protocolo de geração de blastos de linfócitos T CD8 apresentou ótima eficiência de eliminação das células positivas para CD4 e expansão do número de linfócitos T CD8 (Blasto CD8 -figura 30). 

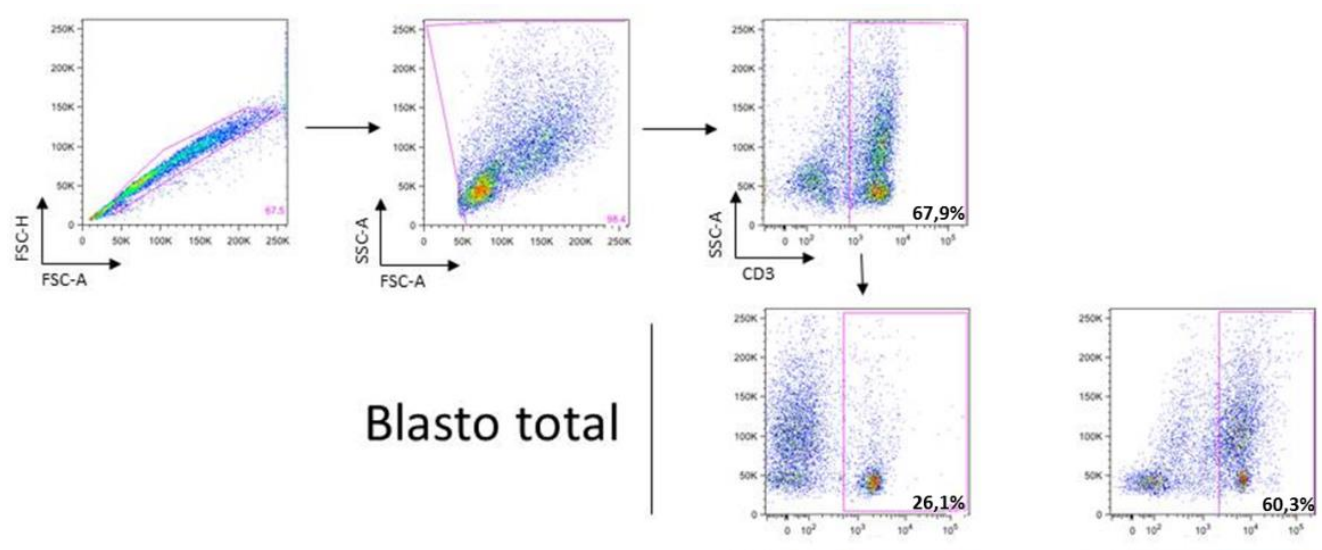

Blasto CD8
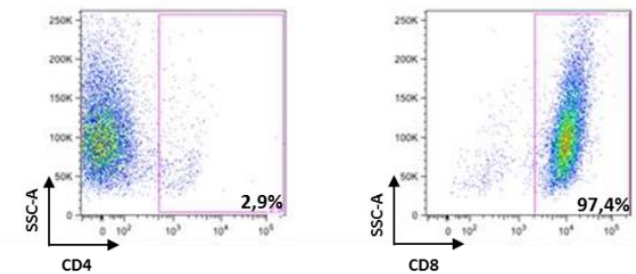

Figura 30-Caracterização fenotípica de blastos de linfócitos T CD8. Células do baço de camundongo C57BI/6 foram tratadas com uma solução hipotônica para lise de eritrócitos. As células restantes foram incubadas com ConA (5 $\mu \mathrm{g} / \mathrm{ml}$ ), 10\% de soro fresco de animais da mesma linhagem e $1 \mathrm{\mu g} / \mathrm{ml}$ de anticorpo anti-CD4 durante 48 horas e então lavadas e replaqueadas na presença de $250 \mathrm{U} / \mathrm{ml}$ de rlL-2 por 48 horas. Após este período mais $250 \mathrm{U} / \mathrm{ml}$ de rlL-2 foram adicionados à cultura e incubadas totalizando 7 dias. O compartimento Blasto total refere-se às células que foram retiradas do baço e simplesmente mantidas em cultura. Trezentas mil células foram marcadas com anticorpos anti-CD3(Fitc), anti-CD4 (APCCy7) e anti-CD8 $\alpha$ (PacificBlue) e analisadas por citometria de fluxo.

Embora o número absoluto de linfócitos T CD8 gerados neste experimento foi satisfatório, nós buscamos uma população com o menor número possível de células contaminantes. Para contornar esse problema existiam duas opções, a separação celular por meio de citometria de fluxo (cell sorting) ou a utilização de kits comerciais de separação celular. A segunda abordagem foi escolhida e os dados desse protocolo podem ser observados adiante.

A avaliação do protocolo de separação celular mostrou-se satisfatória, conforme podemos observar pela análise dos dados na figura 31, resultando numa pureza de quase 98\% de linfócitos T CD8 após a realização do protocolo e quase ausência de linfócitos T CD4. O kit de separação mostrou-se muito prático e eficiente para purificação e enriquecimento de linfócitos T CD8 provenientes do protocolo de geração de blastos. Entretanto, em outro experimento visando isolar células provenientes diretamente do baço, o kit não demonstrou a mesma eficiência (dados não mostrados), indicando ser fundamental o protocolo precedente de geração de blastos. 

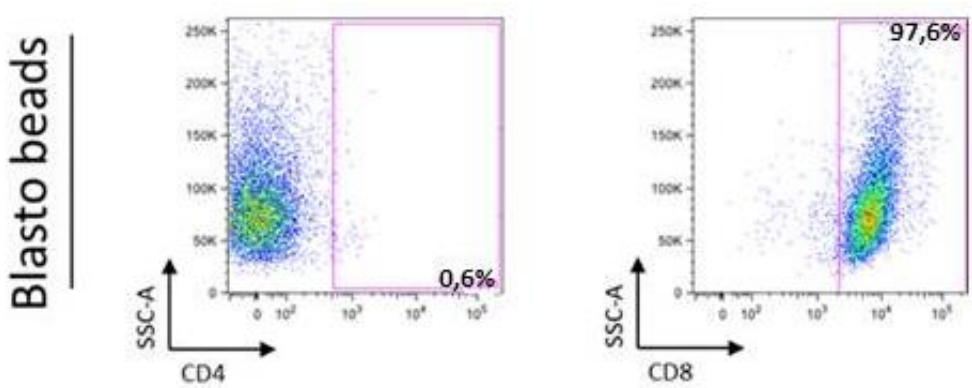

Figura 31 - Caracterização fenotípica dos blastos de linfócitos T CD8 submetidos ao protocolo de separação utilizando beads magnéticas. $1 \times 10^{8}$ células provenientes do protocolo de geração de blastos foram submetidas a um protocolo adaptado de separação magnética e posteriormente foi avaliada a população de linfócitos T CD4 e T CD8. Trezentas mil células foram marcadas com anticorpos anti -CD3 (Fitc), -CD4 (APC-Cy7) e -CD8 $\alpha$ (PacificBlue) e analisadas por citometria de fluxo. A estratégia de gate adotada foi a mesma do protocolo de geração de blastos de linfócitos T CD8 e por isso foi omitida desta figura.

O protocolo de geração de blastos, em conjunto com este protocolo de purificação foi utilizado para realização dos ensaios de transdução para silenciamento gênico da RAB2A em linfócitos T CD8 provenientes do baço e linfonodos de camundongos C56BL/6.

Outro passo necessário durante o processo de transdução utilizando shRNA foi a determinação da concentração ótima de purominicina para seleção das células que expressam o shRNA, e concomitantemente, o gene de resistência para Puromicina. É sabido que cada linhagem celular responde de maneira diferente à Puromicina. De acordo com uma recomendação da Addgene (www.addgene.org), nós determinamos a concentração ótima de Puromicina, isso quer dizer, a concentração mínima de Puromicina capaz de provocar a morte completa das células entre 3-5 dias, para esplenócitos murinos não transduzidos e os resultados desse experimento podem ser vistos na seguir (figura 32).
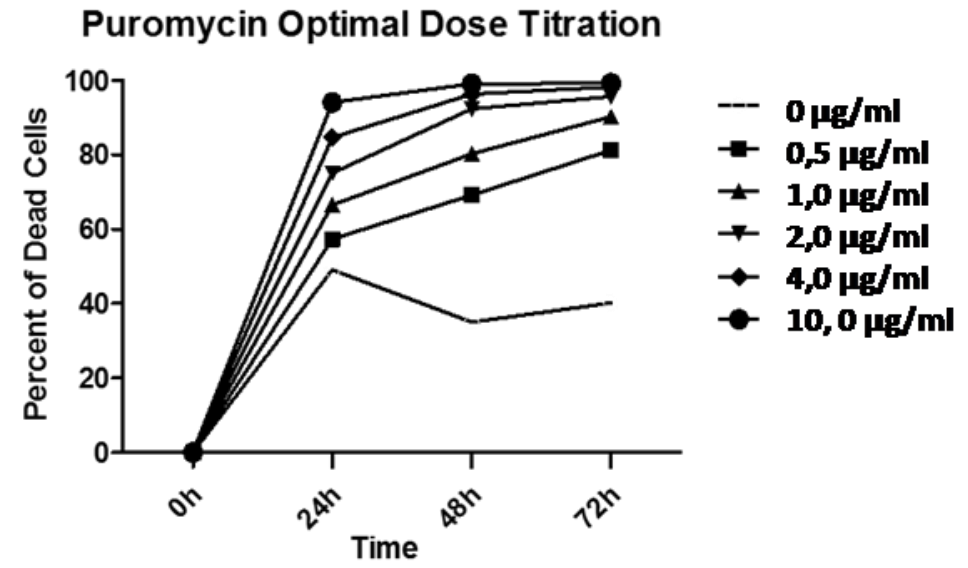

Figura 32 Curva de titulação para determinação da dose ótima de Puromicina em células murinas primárias. $1 \times 10^{6}$ esplenócitos foram plaqueados em placas de 24 poços por até 72 horas com meio de cultura e tratados com diferentes 
doses de Puromicina. Cada ponto da curva foi coletado diariamente, marcado com LIVE/DEAD e analisado por citometria de fluxo.

A análise do gráfico permite determinar que a melhor dose de antibiótico para selecionar esplenócitos murinos foi de $1 \mu \mathrm{g} / \mathrm{ml}$ de Puromicina e foi adotada para selecionar as células murinas transduzidas.

As etapas iniciais referentes ao processo de transdução celular propriamente dito, que incluem os protocolos de clonagem dos oligos no vetor pLKO.1 foram desenvolvidas em colaboração com a Dra. Barbara Mello, no Memorial Sloan Kettering Cancer Center (Nova York, EUA), no laboratório do Dr. Scott Lowe e enviadas para o Brasil. Em seguida, foi realizado no laboratório a transformação bacteriana, a mini preparação plasmidial, a produção do vetor lentiviral e a transdução de células provenientes dos protocolos descritos acima.

Apesar dos nossos esforços para silenciar a RAB2A em células primárias murinas utilizando shRNA, nós não obtivemos êxito visto que 100\% dascélulas morriam com menos de 14 dias do início do protocolo. Nós tentamos adicionar IL-2 na cultura, reestimular as células com PMA/Ionomicina ou Concanavalina-A, mudamos a quantidade de vitaminas e SFB do meio, mas tudo sem sucesso. Diante da dificuldade de obter células primárias viáveis e na ausência de uma linhagem de linfócitos T CD8, nosso grupo partiu para uma segunda abordagem utilizando um protocolo mais recente conhecido como CRISPR/CAS-9.

\subsection{Protocolo De Edição Genômica Utilizando CRISPR/CAS-9}

\subsubsection{Digestão do plasmídeo LentCrispr v2 com enzima BsmBI}

Inicialmente $5 \mu \mathrm{g}$ do plasmídeo foram digeridos utilizando a enzima BsmBI. Os produtos dessa reação são duas bandas, uma maior (perto de $12 \mathrm{~Kb}$ ) e outra menor (por volta de $2 \mathrm{~Kb}$ ).O resultado dessa reação pode ser observado na figura 33. 


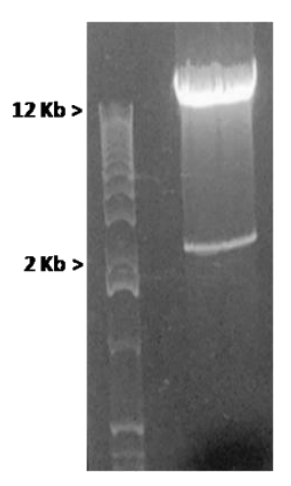

Figura 33 - Digestão do vetor lentiviral lentCRISPR v2. Cinco $\mu$ g de lentiCRISPR v2 (Addgene, Cambridge, MA) foram misturados a 0,5 $\mu \mathrm{l}$ da enzima BsmBI (New England Biolabs, Ipswich, MA) e incubados por três horas à $55{ }^{\circ} \mathrm{C}$ em um aparelho Thermomixer (Thermo Fisher,Waltham, MA). Foi efetuada uma corrida eletroforética em gel de agarose a $1 \%$ por 1,5 hora a $70 \mathrm{~V}$ e as bandas foram reveladas utilizando GelRed (Biotium,Hayward, CA) em um aparelho transiluminador.

A banda maior foi então purificada utilizando um kit comercial de acordo com as instruções do fabricante, quantificada com um NanoDrop 2000 (Thermo Fisher) e armazenada em freezer- $80^{\circ} \mathrm{C}$ até o uso. A banda menor descartada.

\subsubsection{Desenho e validação dos gRNA}

Foram utilizadas duas ferramentas de bioinformática para desenho dos gRNA. A primeira delas, o DNA2.0 gRNA Design Tool (https://www.dna20.com) fornece uma lista sítios alvo da Cas9 baseados na especificidade predita. O programa utiliza um algoritmo baseado na ocorrência de 12 pares de bases que antecedem os PAM NGG e NAG. A Sequência escolhida foi GTACATCATAATCGGCGACA e recebeu o nome de gRNA-1 e uma 
imagem representativa da tela do programa pode ser vista na figura 34 .
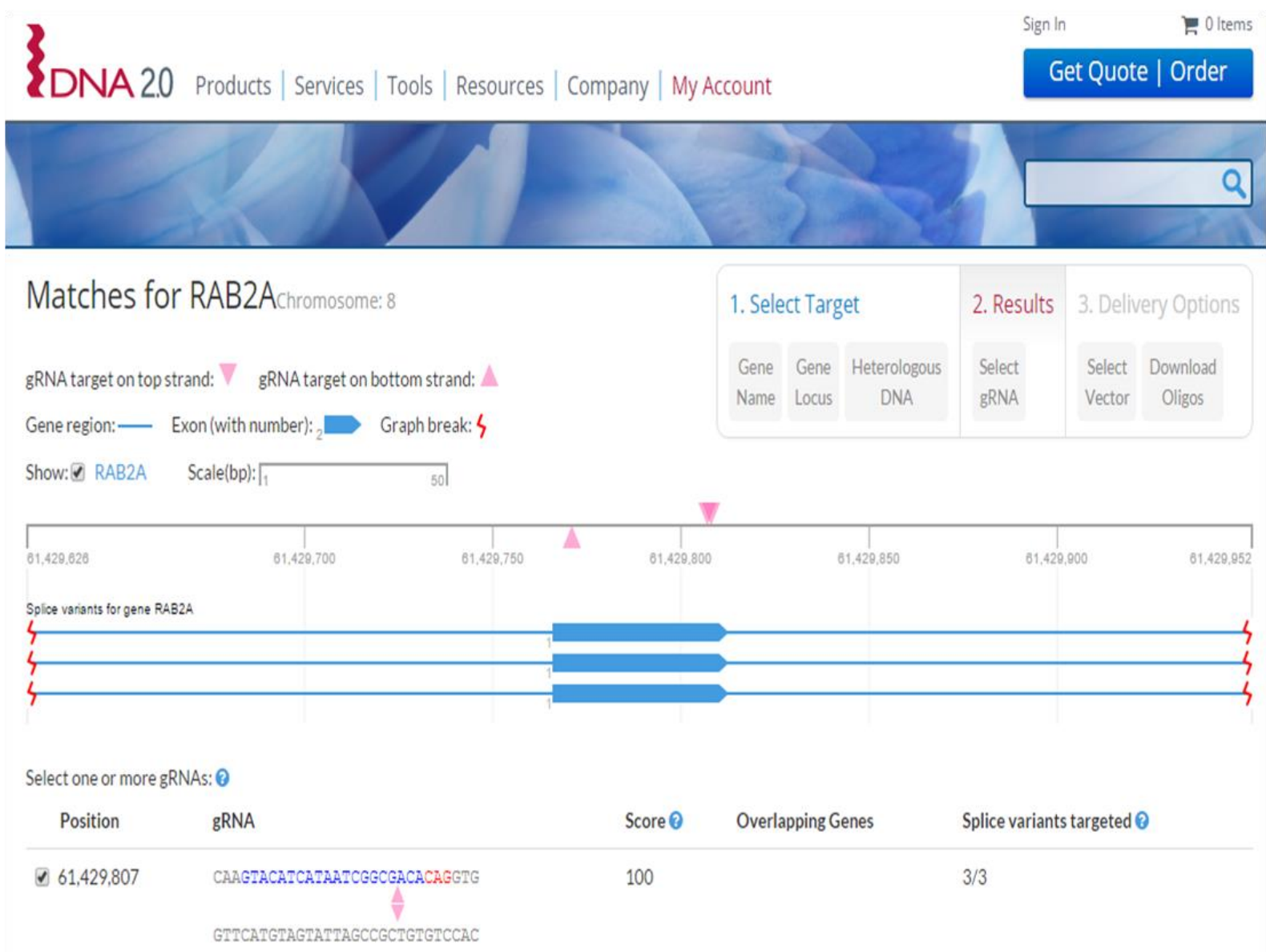

Figura 34 - Imagem ilustrativa do software para desenho de gRNA para RAB2A humana do site DNA 2.0 . Na imagem podese observar a posição do gRNA no gene da RAB2A, além disso é possível ver que essa construção atinge o score máximo no programa e consegue atingir até três variantes (splices) do gene (https://www.dna20.com).

O segundo programa utilizado foi o gRNA design tool (http://www.genscript.com) da GenScript. De maneira resumida, o programa utiliza quatro princípios para a geração do gRNA: 1 - Identificar o gene/lócus alvo; 2 - determinar uma sequência alvo adequada para ação da Cas-9; 3 - Verificar a existência de possíveis sítios de ligação inespecíficos; 4 Selecionar os gRNA que se encontram dentro da região de ligação desejada. A Sequência gRNA-2 foi CCAGTGCATGACCTTACTAT e uma imagem representativa da tela do programa pode ser vista na figura 35. 
GenScript

Make Research Easy

\section{English}

Log In | Place Order | My Cart | Contact | Reward Center

\section{RAB2A CRISPR guide RNA, RAB2A, member RAS oncogene family CRISPR guide RNA[human]}

The following gRNA sequences will uniquely target your gene of interest within the genome. Select the sequences you'd like to use. On the next page you'll be able to choose from GenScript's free all-in-one gRNA-Cas 9 vectors and order expression-ready clones for just $\$ 199$.

Read more about our gRNA design algorithm and gRNA construct service below this results table. For help, hover over?

\begin{tabular}{|c|c|c|}
\hline $\begin{array}{l}\text { gRNA } \\
\text { (name) }\end{array}$ & gRNA target sequence & Select \\
\hline RAB2A CRISPR guide RNA 1 & CCAGTGCATGACCTTACTAT & O \\
\hline RAB2A CRISPR guide RNA 2 & TCTGTAATACGACCTTGTGA & 0 \\
\hline RAB2A CRISPR guide RNA 3 & GCTCGAATGATAACTATTGA & Q \\
\hline RAB2A CRISPR guide RNA 4 & AATCCTTTCGTTCCATCACA & 0 \\
\hline RAB2A CRISPR guide RNA 5 & CCAATAGTAAGGTCATGCAC & $\square$ \\
\hline RAB2A CRISPR guide RNA 6 & CTCTATTTAGGTGTAGAGTT & ○ \\
\hline
\end{tabular}

Figura 35 - Imagem ilustrativa do software para desenho de gRNA para RAB2A humana do site GenScript . Na imagem é possivel observar seis gRNApara RAB2A humana (http://www.genscript.com).

As sequências geradas em ambas as plataformas foram validadas utilizando um terceiro programa intitulado Matcher Mobile Pasteur (http://mobyle.pasteur.fr/cgibin/portal.py\#forms::matcher). O programa identifica similaridades entre sequências utilizando um complexo algoritmo e classifica essas sequências. Para a análise foram utilizados dois inputs: os gRNAs desenhados acima e a sequências FASTA validadas da RAB2A humana variantes 1 (NM_002865.2) e 2 (NM_001242644.1). Ambas as sequências obtiveram score máximo na avaliação pelo programa com 100\% de identidade sem nenhum intervalo encontrado entre as sequências pareadas. Os resultados para validação das sequências gRNA-1 e gRNA-2 podem ser vistos na figura 36. 


\section{lent CRISPR v2 gRNA 1}

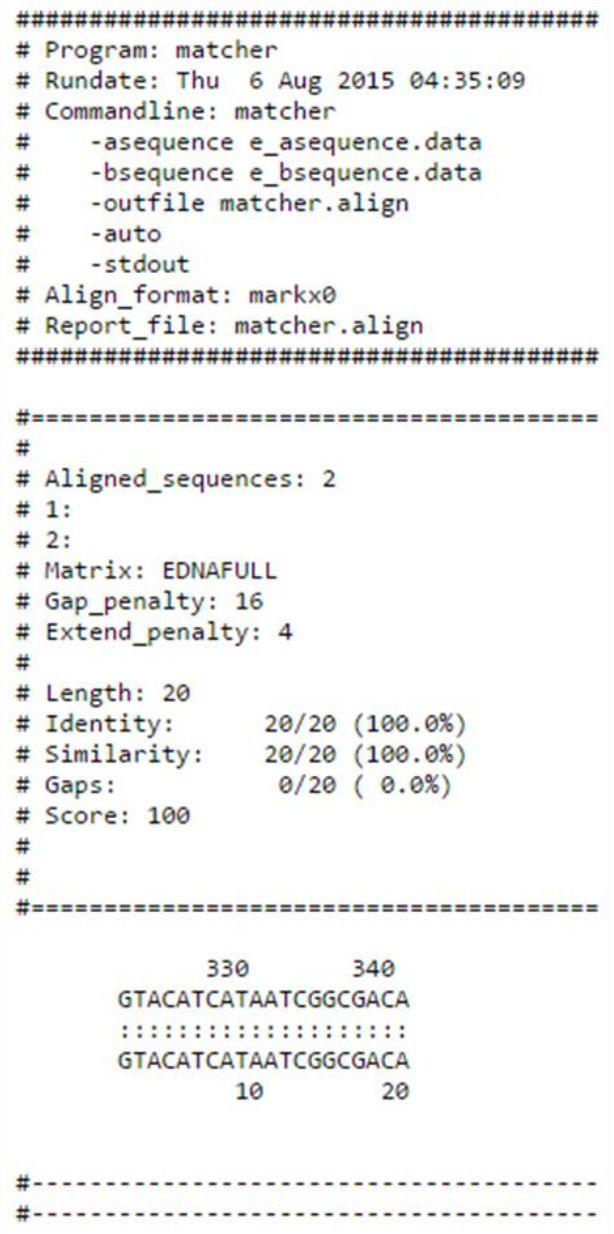

lent CRISPR v2 gRNA 2

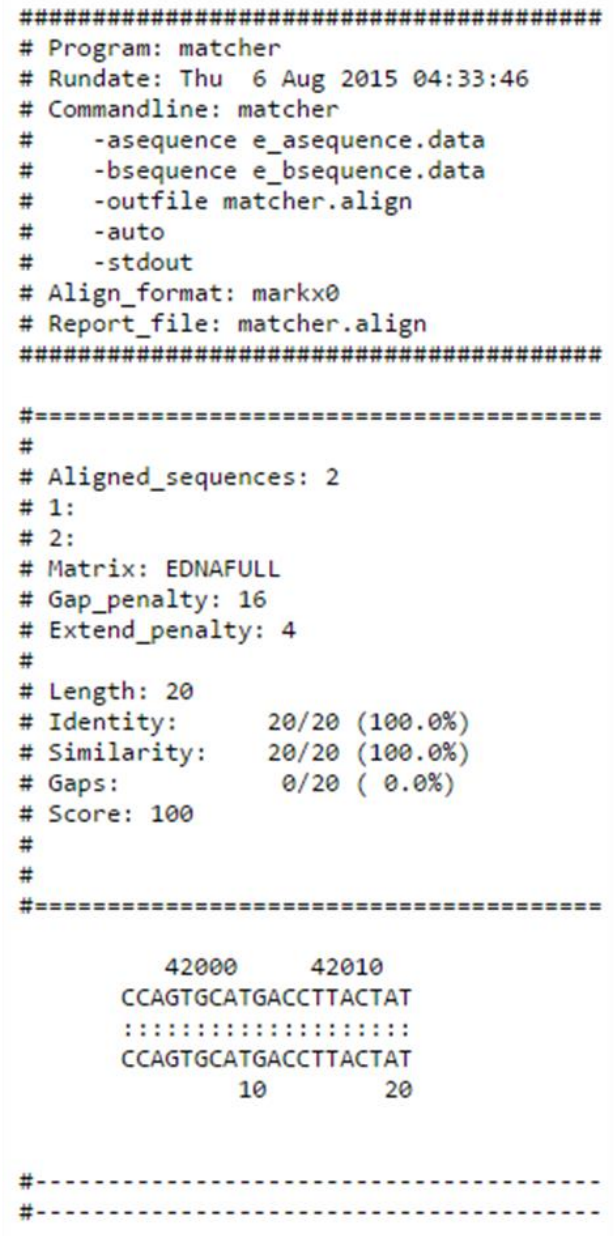

Figura 36 - Imagem ilustrando análise do programa Matcherdos gRNA gerados utilizando ferramentas de bioinformática. A direita da imagem é possível ver a análise para o gRNA-1 (DNA 2.0) e a esquerda é possível ver a análise para o gRNA-2 (GenScript). Ambas as sequências obtiveram score máximo na avaliação pelo programa com $100 \%$ de identidade sem nenhum gap encontrado entre as sequências pareadas Os resultados foram gerados utilizando como inputs os gRNA-1 e -2 e a sequências FASTA validadas da RAB2A humana variantes 1 e 2 (http://mobyle.pasteur.fr/cgibin/portal.py\#forms::matcher).

Foi realizada a fosforilação e anelamento dos pares de oligos, seguida da transformação bacteriana utilizando bactérias stbl3, que foi avaliada por meio de uma PCR de colônia (dados não mostrados). Foi realizada a PCR de sete colônias para cada gRNAe dessas, três clones de cada foram selecionados (gRNA 1-1, gRNA 1-2, gRNA 1-3, gRNA 2-1, gRNA 2-2, gRNA 2-3) expandidos, submetidos ao protocolo de mini-prep e enviados para o sequênciamento. O resultado do sequênciamento foi analisado utilizando o programa 4Peaks e como pode ser observado nas figuras 37 e 38, todos os clones apresentaram a sequência do seu respectivo gRNA. 


\section{gRNA 1-1 (DNA 2.0) TACATCATAATCGGCGACAC}

CTCCAAAATCGGAATCCAAGGGCTGTTAGAGAGATAATTAGAATTAATTTGACTGTAAACACAAAGATATTAGTACAAAATAAGAGACGTAGAAAGT AATAATTTCTTGGGTAGTTTGCAGTTTTAAAATTATGTTTTAAAATGGACTATCATATGCTTACCGTAACTTGAAAGTATTTCGATTTCTTGGCTTTA TATATCTTGTGGAAAGGACGAAACACCGTACATCATAATCGGCGACACGTTTTAGAGCTAGAAATAGCAAGTTAAAATAAGGCTAGTCCGTTATCAAC TTGAAAAAGTGGCACCGAGTCGGTGCTTTTTTGAATTCGCTAGCTAGGTCTTGAAAGGAGTGGGAATTGGCTCCGGTGCCCGTCAGTGGGCAGAGCGC ACATCGCCCACAGTCCCCGAGAAGTTGGGGGGAGGGGTCGGCAATTGATCCGGTGCCTAGAGAAGGTGGCGCGGGGTAAACTGGGAAAGTGATGTCGT GTACTGGCTCCGCCTTTTTCCCGAGGGTGGGGGAGAACCGTATATAAGTGCAGTAGTCGCCGTGAACGTTCTTTTTCGCAACGGGTTTGCCGCCAGAAC ACAGGACCGGTTCTAGAGCGCTGCCACCATGGACAAGAAGTACAGCATCGGCCTGGACATCGGCACCAACTCTGTGGGCTGGGCCGTGATCACCGACGA GTACAAGGTGCCCAGCAAGAAATTCAAGGTGCTGGGCAACACCGACCGGCACAGCATCAAGAAGAACCTGATCGGAGCCCT GCTGTTCGACAGCGGCGA AACAGCCGATGCCACCCGGCTGAAGAGAACCGCCAGAAGAAGATACACCAGACCGGAAGAACCCGGATCTGCTATCTTGCAAGAGATCTTCAGCAACGA GATGGGCCCAAGGTGACGGACAGCCTTCTTCAACAGACTTGAGAGTCCTTCCCTGGCTGGCAAGGAAAGGCATATTCAG

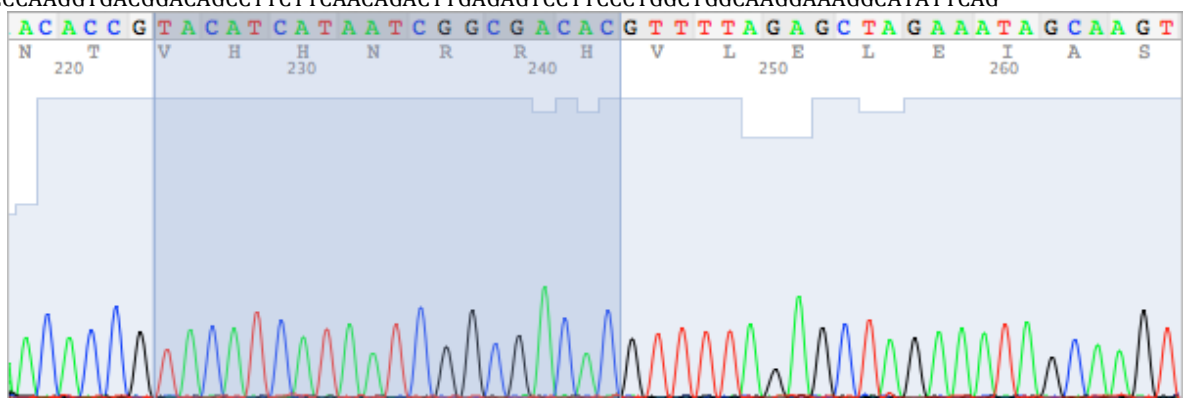

gRNA 1-2 (DNA 2.0) TACATCATAATCGGCGACAC

CGGCCATTTTCGAATACAGGCTGTTAGAGAGATAATTAGAATTAATTTGACTGTAAACACAAAGATATTAGTACAAAATAAGAGACGAAGAAAGTAA TAATTTCTTGGGTAGTTTGCAGTTTTAAAATTATGAATTTAAAATGGACTATCATATGCTTACCGTAACTTGAAAGTATTTCGATTTCTTGGCTTTAT ATATCTTGTGGAAAGGACGAAACACCGTACATCATAATCGGCGACACGTTTTAGAGCTAGAAATAGCAAGTTAAAATAAGGCTAGTCCGTTATCAACT TGAAAAAGTGGCACCGAGTCGGTGCTTTTTTGAATTCGCTAGCTAGGTCTTGAAAGGAGTGGGAATTGGCTCCGGTGCCCGTCAGTGGGCAGAGCGCA CATCGCCCACAGTCCCCGAGAAGTTGGGGGGAGGGGTCGGCAATTGATCCGGTGCCTAGAGAAGGTGGCGCGGGGTAAACTGGGAAAGTGATGTCGTG TACTGGCTCCGCCTTTTTCCCGAGGGTGGGGGAGAACCGTATATAAGTGCAGTAGTCGCCGTGAACGTTCTTTTTCGCAACGGGTTTGCCGCCAGAACA CAGGACCGGTTCTAGAGCGCTGCCACCATGGACAAGAAGTACAGCATCGGCCTGGACATCGGCACCAACTCTGTGGGCTGGGCCGTGATCACCGACGAG TACAAGGTGCCCAGCAAGAAATTCAAGGTGCTGGGCAACACCGACCGGCACAGCATCAAGAAGAACCTGATCGGAGCCCTGCTGTTCGACAGCGGCGAA ACAGCCCGAGGCCACCCCGGCTGATGAGAACCGCCAGAAGGAGGATACACCACGACCGGAGGGAACCGGATCTGCTTATCTGGCAAGAGATCTTTCAGC AACCGAGATGGGCCAAGGTGGAACGTCCAGCCTTCTTCCCAAGACCTGGGCAGAAGGTTCCTCCCCTGGCTGGAAGAAGTGGATAATAG

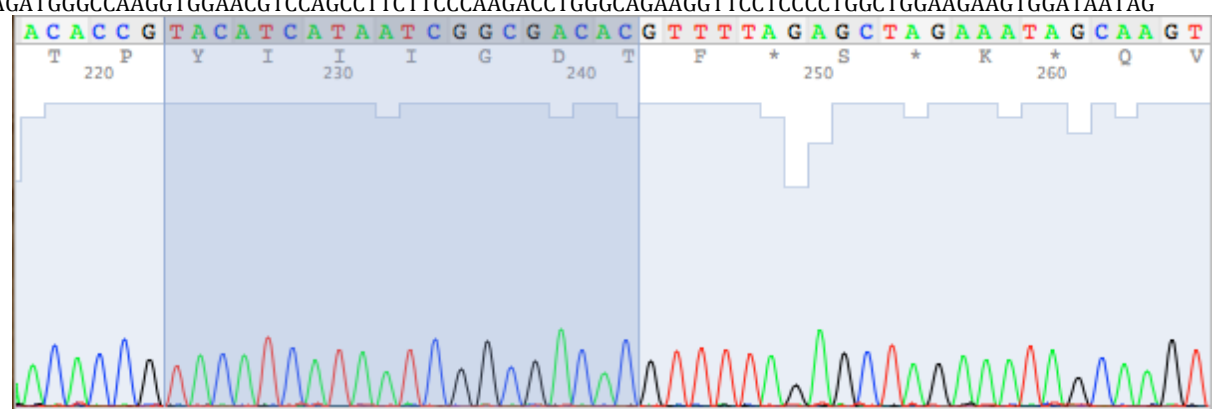

gRNA 1-3 (DNA 2.0) TACATCATAATCGGCGACAC

TTCCATAAACGATACAAGGCTGTTAGAGAGATAATTAGAATTAATTTGACTGTAAACACAAAGATATTAGTACAAAATAGAGACGTAGAAAGTAATA ATTTCTTGGGTAGTTTGCAGTTTTAAAATTATGTTTTAAAATGGACTATCATATGCTTACCGTAACTTGAAAGTATTTCGATTTCTTGGCTTTATATA TCTTGTGGAAAGGACGAAACACCGTACATCATAATCGGCGACACGTTTTAGAGCTAGAAATAGCAAGTTAAAATAAGGCTAGTCCGTTATCAACTTGA AAAAGTGGCACCGAGTCGGTGCTTTTTTGAATTCGCTAGCTAGGTCTTGAAAGGAGTGGGAATTGGCTCCGGTGCCCGTCAGTGGGCAGAGCGCACATC GCCCACAGTCCCCGAGAAGTTGGGGGGAGGGGTCGGCAATTGATCCGGTGCCTAGAGAAGGTGGCGCGGGGTAAACTGGGAAAGTGATGTCGTGTACT GGCTCCGCCTTTTTCCCGAGGGTGGGGGAGAACCGTATATAAGTGCAGTAGTCGCCGTGAACGTTCTTTTTCGCAACGGGTTTGCCGCCAGAACACAGG ACCGGTTCTAGAGCGCTGCCACCATGGACAAGAAGTACAGCATCGGCCTGGACATCGGCACCAACTCTGTGGGCTGGGCCGTGATCACCGACGAGTACA AGGTGCCCAGCAAGAAATTCAAGGTGCTGGGCAACACCGACCGGCACAGCATCAAGAAGAACCTGATCGGAGCCCTGCTGTTCGACAGCGGCGAAACAG CCGAGGCCACCCGGCTGAAGAGAACCGCCAGAAGAAGATACACCAGACGGAAGACCGGGATCTGCTATCTGCAAGAGATCTTCAGCAACGAGATGGCCC AAGGTGGACGACAGCTTCCTCACAGGACTGCAGAGTTCCTTCCCTGGGTGAAGAAAGGAATTATAAGAGAAAAAGG

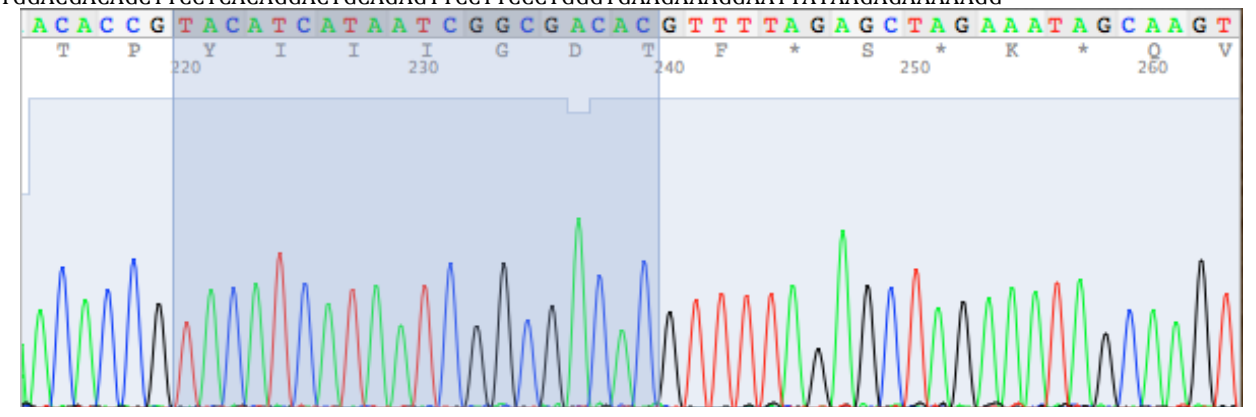

Figura 37 - Análise de sequênciamento de três clones de bactérias diferentes portando o gRNA-1 desenvolvido no programa DNA 2.0 (gRNA-1-1; gRNA-1-2; gRNA-1-3). No topo de cada grupo de imagens podemos evidenciar o resultado cru do sequênciamento destacando em amarelo o gRNA-1. Abaixo podemos evidenciar a tela do visualizador de sequências programa 4peaks, onde novamente está destacada a sequência do gRNA-1. 


\section{gRNA 2-1 (Genescript) GCCGGCGGCCGCAGAACTTC}

CGCCATTTCGATACAAGGCTGTTAGAGAGATAATTAGAATTAATTTGACTGTAAACACAAAGATATTAGTACAAAATAAGAGACGTAGAAAGTAATA ATTTCTTGGGTAGTTTGCAGTTTTAAAATTATGTTTTAAAATGGACTATCATATGCTTACCGTAACTTGAAAGTATTTCGATTTCTTGGCTTTATATA TCTTGTGGAAAGGACGAAACACCGGCCGGCGGCCGCAGAACTTCGTTTTAGAGCTAGAAATAGCAAGTTAAAATAAGGCTAGTCCGTTATCAACTTAA AAAAGTGGCACCGAGTCGGTGCTTTTTTGAATTCGCTAGCTAGGTCTTGAAAGGAGTGGGAATTGGCTCCGGTGCCCGTCAGTGGGCAGAGCGCACATC GCCCACAGTCCCCGAGAAGTTGGGGGGAGGGGTCGGCAATTGATCCGGTGCCTAGAGAAGGTGGCGCGGGGTAAACTGGGAAAGTGATGTCGTGTACT GGCTCCGCCTTTTTCCCGAGGGTGGGGGAGAACCGTATATAAGTGCAGTAGTCGCCGTGAACGTTCTTTTTCGCAACGGGTTTGCCGCCAGAACACAGG ACCGGTTCTAGAGCGCTGCCACCATGGACAAGAAGTACAGCATCGGCCTGGACATCGGCACCAACTCTGTGGGCTGGGCCGTGATCACCGACGAGTACA AGGTGCCCAGCAAGAAATTCAAGGTGCTGGGCAACACCGACCGGCACAGCATCAAGAAGAACCTGATCGGAGCCCTGCTGTTCGACAGCGGCGAAACAG CCGAGGCCACCCGGGCTGAAGAGAACCGCCAGAAGAAGATACACCAGACGGAAGAACCCGGGATCTGCTATCTGCAAGAGATCTTCAGCAACGAGATG GGCCCAACGTGCACGACAGGCTCATCACAGACCTGCAAAGAGTTCCCTTTTCCTTGGGTGGGAAAAGAGATGGTA

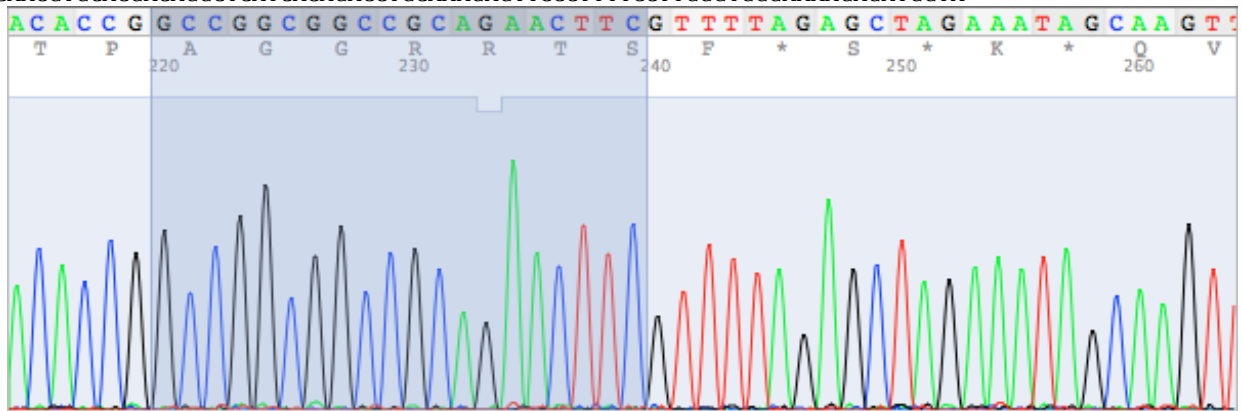

gRNA 2-2 (Genescript) GCCGGCGGCCGCAGAACTTC

TTTCAATATCGAATACAGGCTGTTAGAGAGATAATTAGAATTAATTTGACTGTAAACACAAAGATATTAGTACAAAATATGTGACGTAGAAAGTAAT AATTTCTTGGGTAGTTTGCAGTTTTAAAATTATGTTTTAAAATGGACTATCATATGCTTACCGTAACTTGAAAGTATTTCGATTTCTTGGCTTTATAT ATCTTGTGGAAAGGACGAAACACCGGCCGGCGGCCGCAGAACTTCGTTTTAGAGCTAGAAATAGCAAGTTAAAATAAGGCTAGTCCGTTATCAACTTG AAAAAGTGGCACCGAGTCGGTGCTTTTTTGAATTCGCTAGCTAGGTCTTGAAAGGAGTGGGAATTGGCTCCGGTGCCCGTCAGTGGGCAGAGCGCACA TCGCCCACAGTCCCCGAGAAGTTGGGGGGAGGGGTCGGCAATTGATCCGGTGCCTAGAGAAGGTGGCGCGGGGTAAACTGGGAAAGTGATGTCGTGTA CTGGCTCCGCCTTTTTCCCGAGGGTGGGGGAGAACCGTATATAAGTGCAGTAGTCGCCGTGAACGTTCTTTTTCGCAACGGGTTTGCCGCCAGAACACA GGACCGGTTCTAGAGCGCTGCCACCATGGACAAGAAGTACAGCATCGGCCTGGACATCGGCACCAACTCTGTGGGCTGGGCCGTGATCACCGACGAGTA CAAGGTGCCCAGCAAGAAATTCAAGGTGCTGGGCAACACCGACCGGCACAGCATCAAGAAGAACCTGATCGGAGCCCTGCTGTTCGACAGCGGCGAAAC AGCCGAGGCCACCCGGCTGAAGAGAACCGCCAGAGAGATACACCAGACGGAGAACCCGGATCTGCTATCTGCAAGAGATCTTCAGCAACGAGATGGGCC CAAGTGGACGACAGCCTTCTCACAGGACTTGCCAGAAGTCCTTTCCTTGGGTGAAAAGAGAGAAGGTAATA

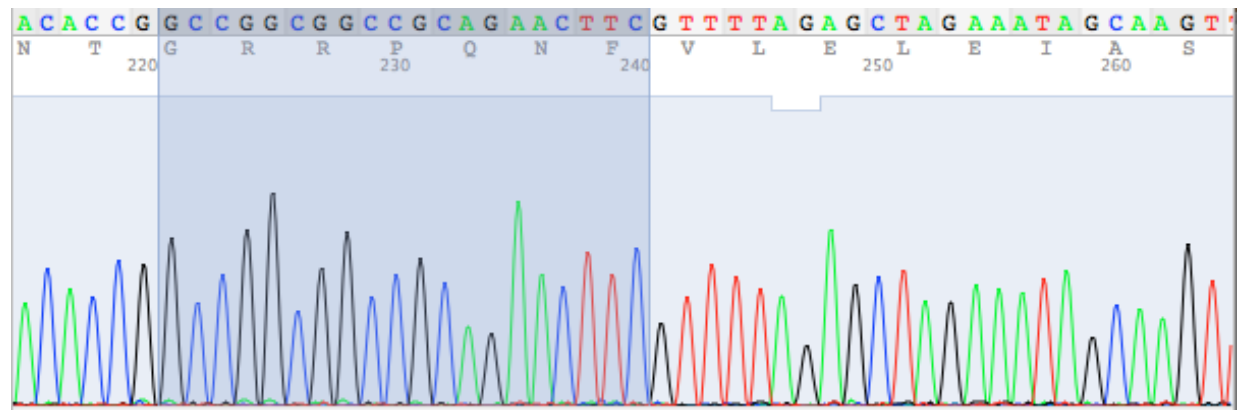

gRNA 2-3 (Genescript) GCCGGCGGCCGCAGAACTTC

TGTCATAACGAATACAAGGCTGTTAGAGAGATAATTAGAATTAATTTGACTGTAAACACAAAGATATTAGTACAAAATAAGTGACGTAGAAAGTAAT AATTTCTTGGGTAGTTTGCAGTTTTAAAATTATGTTTTAAAATGGACTATCATATGCTTACCGTAACTTGAAAGTATTTCGATTTCTTGGCTTTATAT ATCTTGTGGAAAGGACGAAACACCGGCCGGCGGCCGCAGAACTTCGTTTTAGAGCTAGAAATAGCAAGTTAAAATAAGGCTAGTCCGTTATCAACTTG AAAAAGTGGCACCGAGTCGGTGCTTTTTTGAATTCGCTAGCTAGGTCTTGAAAGGAGTGGGAATTGGCTCCGGTGCCCGTCAGTGGGCAGAGCGCACA TCGCCCACAGTCCCCGAGAAGTTGGGGGGAGGGGTCGGCAATTGATCCGGTGCCTAGAGAAGGTGGCGCGGGGTAAACTGGGAAAGTGATGTCGTGTA CTGGCTCCGCCTTTTTCCCGAGGGTGGGGGAGAACCGTATATAAGTGCAGTAGTCGCCGTGAACGTTCTTTTTCGCAACGGGTTTGCCGCCAGAACACA GGACCGGTTCTAGAGCGCTGCCACCATGGACAAGAAGTACAGCATCGGCCTGGACATCGGCACCAACTCTGTGGGCTGGGCCGTGATCACCGACGAGTA CAAGGTGCCCAGCAAGAAATTCAAGGTGCTGGGCAACACCGACCGGCACAGCATCAAGAAGAACCTGATCGGAGCCCTGCTGTTCGACAGCGGCGAAAC AGCCGAGGCCACCCGGCTGAGAGAACCGCCAGAGAAGATACACCAGACGAGAACCGGGATCTGCTATCTGCAAGAGATCTTCAGCACGAGATGGCCAA GGTGGACGACAGCTCCTCACAGACTGAGAGTTCATCGTGGGTGGAGGAGGAATAAGGAAGAAGGCT

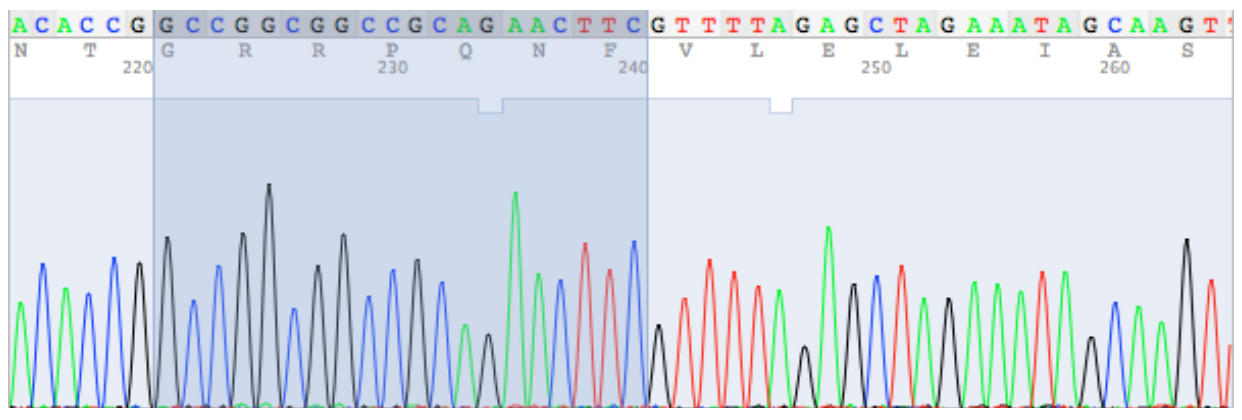

Figura 38- Análise de sequênciamento de três clones de bactérias diferentes portando o gRNA-2 desenvolvido no programa GenScript (gRNA-2-1; gRNA-2-2; gRNA-2-3). No topo de cada grupo de imagens podemos evidenciar o resultado cru do sequênciamento destacando em amarelo o gRNA-1. Abaixo podemos evidenciar a tela do visualizador de sequências programa 4peaks, onde novamente está destacada a sequência do gRNA-1. 


\subsubsection{Transfecção de Células HEK293T}

A transfecção para produção de partículas lentivirais foi realizada em células HEK293T, conforme o protocolo descrito na seção Materiais e Métodos. Foram inseridos diversos controles do experimento nesta etapa visando garantir a qualidade do experimento em questão e dos próximos. Nós incluímos um controle no qual adicionamos apenas o agente de transfecção PEI; outro poço continha PEI, e os plasmídeos pCMV-VSV-G e psPAX2 (vetor vazio); um terceiro poço continha PEI, pCMV-VSV-G e psPAX2 e um plasmídeo com uma sequência irrelevante em humanos (HU NTC); um controle adicional continha PEI, pCMV-VSV-G e psPAX2, além de uma construção que expressava o gene do receptor de interferon em vermelho (controle positivo). Foram selecionados aleatoriamente dois gRNA (um construído no Genescript (gRNA-1) e outro no DNA2.0 (gRNA-2) e utilizados para construção das partículas virais. Os sobrenadantes foram coletados após 24 horas, 48 horas e 72 horas e armazenados em freezer $-80{ }^{\circ} \mathrm{C}$ até o momento de sua utilização.

Um controle interno bastante utilizado em experimentos de transfecção é a utilização de um vetor a fim de avaliar a eficiência da transfeç̧ão (controle positivo). Esse controle pode ser um plasmídeo que expressa constitutivamente uma proteína repórter (no nosso caso utilizamos o receptor de interferon RFP). Esse controle pode ser co-transfectado com o plasmídeo de interesse, ou como nós fizemos, em um poço separado (http://blog.addgene.org/plasmids-101-control-plasmids). O mais importante a ser observado é que a quantidade de proteína repórter se correlaciona com a quantidade de material transfectado para as células empacotadoras e a capacidade dessas células expressarem a proteína. Como podemos observar na figura 39, existe uma quantidade crescente nos níveis de fluorescência conforme o passar dos dias quando observamos as 
células transfectadas

com

0

plasmídeo

repórter.

24H
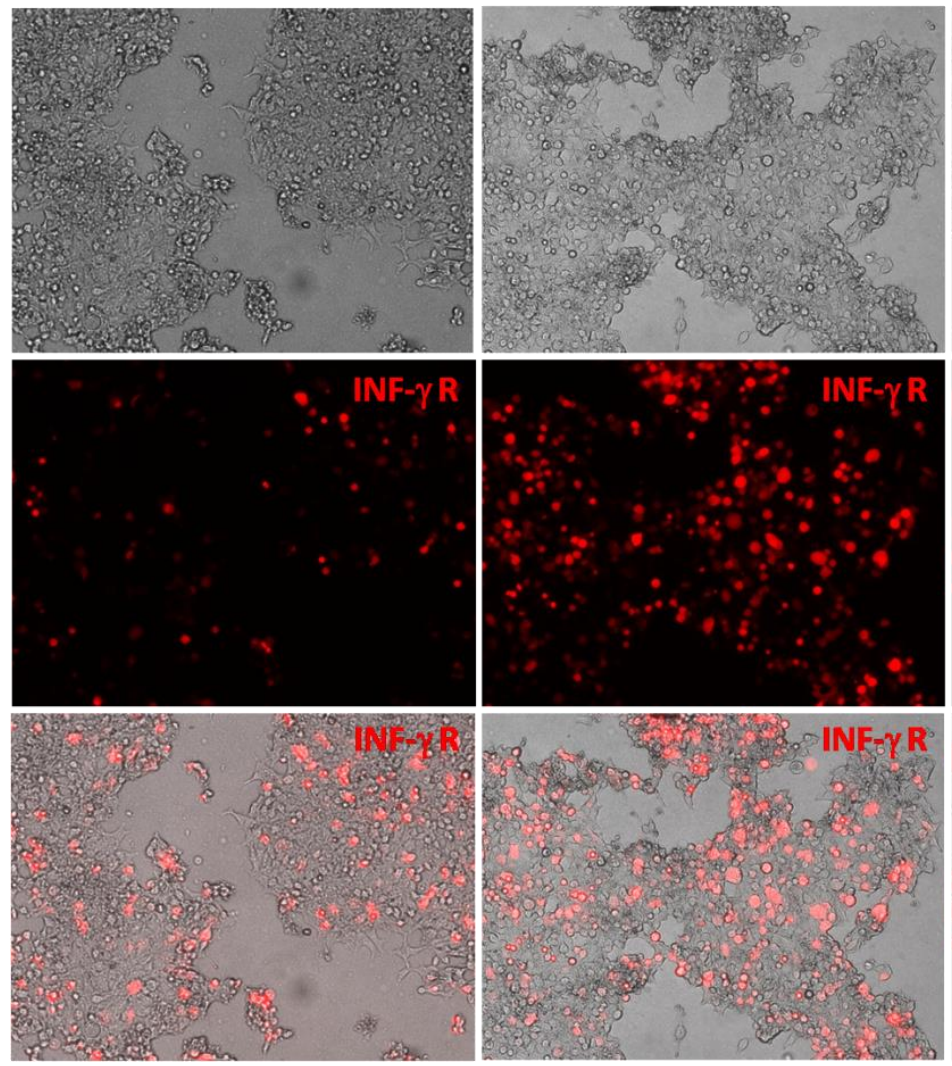

$48 \mathrm{H}$
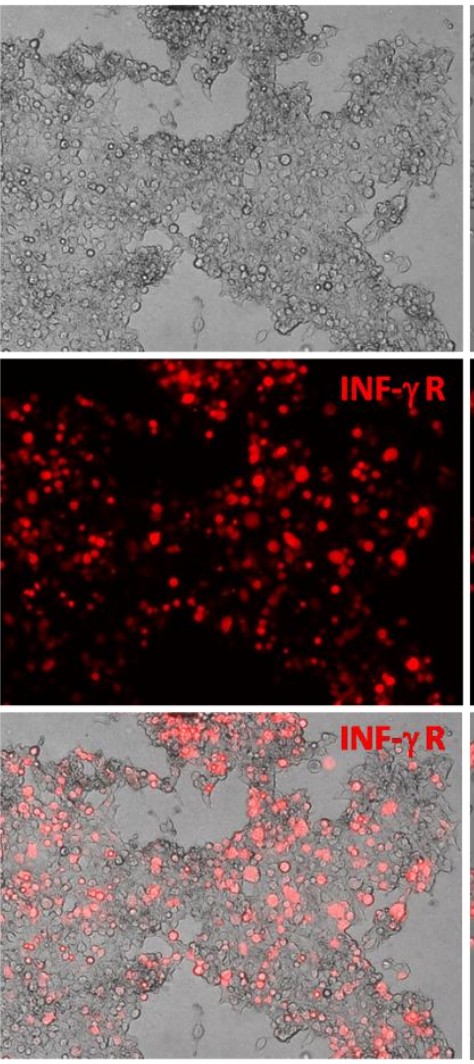

72H
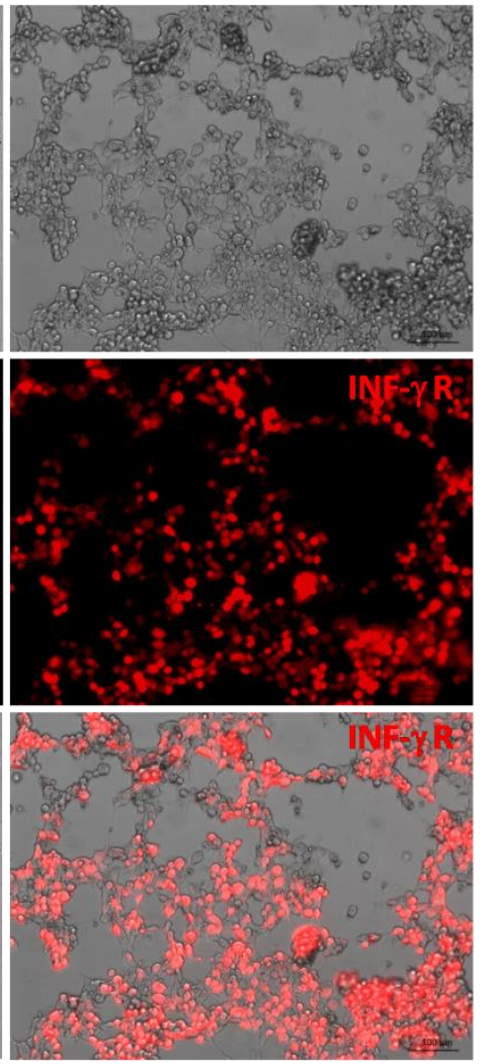

Figura 39 - Células HEK293T transfectadas com plasmídeo contendo gene do receptor de interferon fluorescente com 24 horas, 48 horas e 72 horas após a transfecção. $2 \times 10^{5}$ células HEK 293T foram plaqueadas em placas de 6 poços e transfectadas com plasmídeo contendo gene repórter RFP. A fluorescência foi avaliada com 24 horas, 48 horas e 72 horas após a transfecção em microscópio confocal Zeiss LSM 780-NLO. Aumento de 40 X.

Esse experimento fornece uma evidência indireta bastante significativa de que as células estão sendo transfectadas de maneira satisfatória, atingindo bons índices entre 48 horas e 72 horas. Dessa maneira, os sobrenadantes contendo as partículas virais coletados com 48 horas foram escolhidos para ser utilizados nos experimentos de transdução das células YT.

Outro passo que se fez necessário foi determinar a concentração ótima de puromicina para células YT. Isso foi determinado da mesma maneira que fizemos para esplenócitos murinos e o protocolo pode ser encontrado na seção Materiais e Métodos desta tese. 0 resultado desse experimento pode ser encontrado na figura 40. 


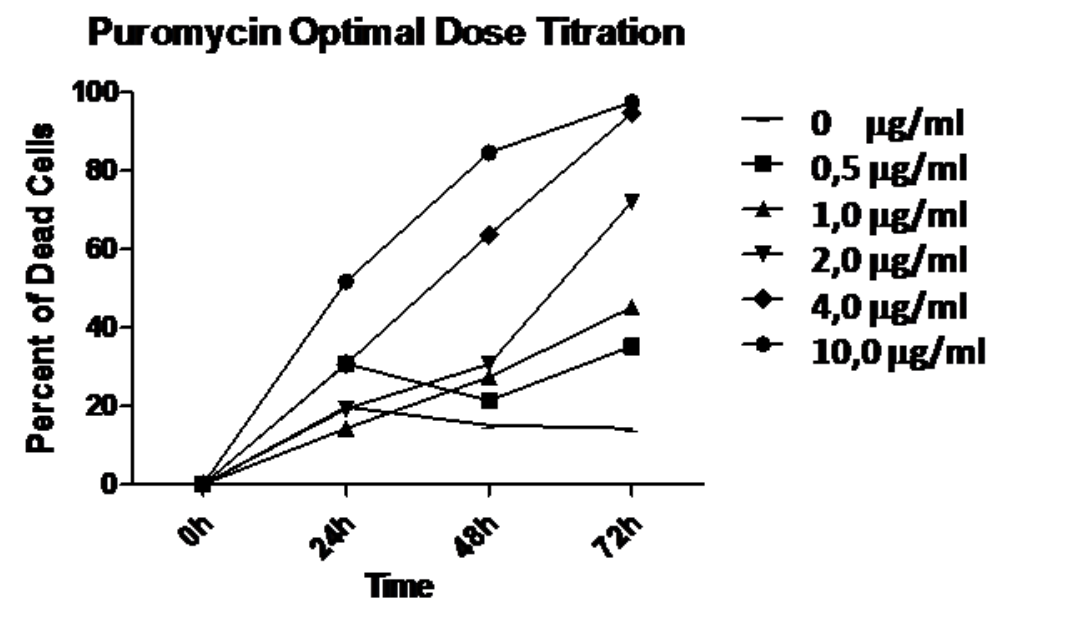

Figura 40 - Curva de titulação para determinação da dose ótima de Puromicina em linhagem celular humana YT. $1 \times 10^{6}$ células YT foram plaqueadas em placas de 24 poços por até 72 horas com meio de cultura e tratadas com diferentes doses de Puromicina. Cada ponto da curva foi coletado diariamente, marcado com LIVE/DEAD e analisado por citometria de fluxo.

A análise do gráfico permite escolher a melhor dose para selecionar células YT. Enquanto que a concentração de $1 \mu \mathrm{g} / \mathrm{ml}$ de Puromicina foi considerada ideal para selecionar esplenócitos murinos, a concentração de $4 \mu \mathrm{g} / \mathrm{ml}$ foi necessária selecionar células YT. É interessante notar a diferença na sensibilidade ao tratamento pelas células de linhagem e células primárias, cerca de quatro vezes menor no caso das células primárias.

Com a concentração de puromicina para a seleção das células YT definida avançamos para a próxima etapa no protocolo que é a transdução destas células.

\subsubsection{Transdução de células YT utilizando partículas lentivirais}

As células YT foram transduzidas utilizando partículas virais conforme descrito na seção Materiais e Métodos e selecionadas utilizando a concentração de puromincina determinada no item anterior. Houve uma intensa mortalidade das células transduzidas, provavelmente devido a uma baixa eficiência do protocolo. Após quase trinta dias em cultura conseguimos número suficiente de células para congelar os primeiros vials contendo as células que foram transduzidas com os vírus portando o gRNA-2, HU NTC e vetor vazio. Essas linhagens foram então submetidas a alguns experimentos de western blot para avaliar o sucesso da transdução. 
De acordo com a figura 41, podemos observar uma discreta redução nos níveis da proteína RAB2A das células que foram transduzidas com o gRNA-2, quando comparadas com as células transduzidas com o gRNA-1, com a sequência irrelevante (HU NTC) e com o vetor vazio (empty vector). Ao analisarmos as bandas na altura de $120 \mathrm{kDa}$, correspondentes a proteína da membrana de lisossomos LAMP-1, não observamos qualquer diferença entre os grupos testados e da mesma maneira, quando analisamos uma proteína do lúmen como perforina por western blot nenhuma diferença é encontrada entre os grupos transduzidos com gRNA-1, gRNA-2, HU NTC e vetor vazio.

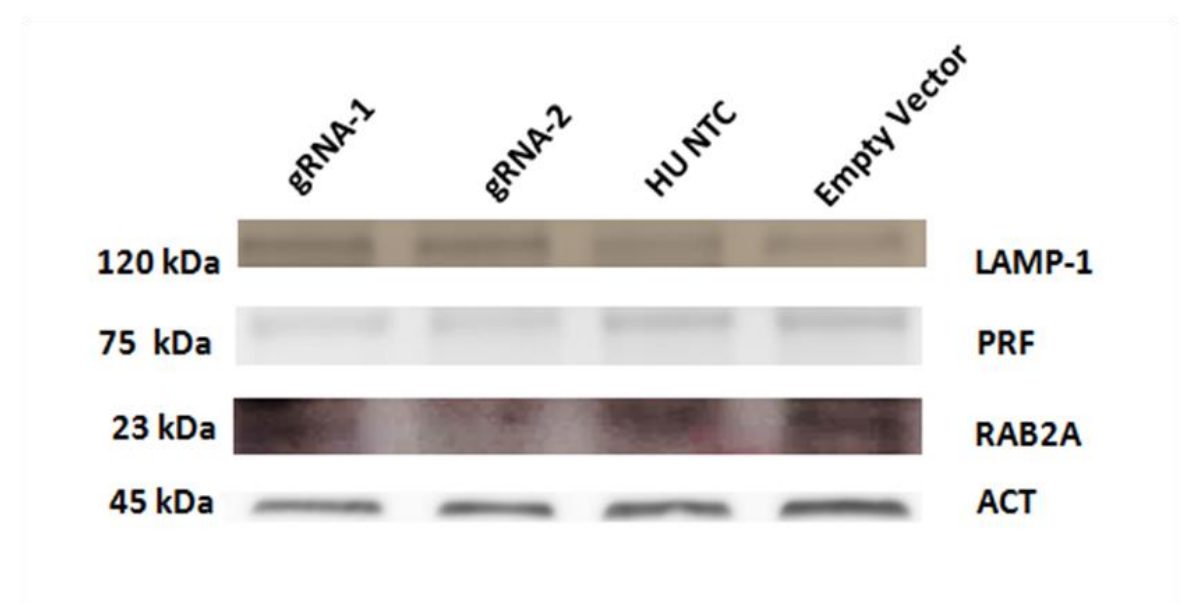

Figura 41- Western blot de células YT transduzidas com CRISPR/CAS9 avaliando a expressão de LAMP-1, RAB2A, perforina e actina. Foram utilizados lentivirus com plasmídeos portando gRNA-1, gRNA-2, uma sequência irrelevante (HU NTC) e um vetor vazio (empty vector) para transdução das células YT. As bandas de 120 kDa, 75 kDa, 23 kDa e 45 kDa correspondem a LAMP-1, perforina, RAB2A e actina, respectivamente. As bandas foram reveladas utilizando ECL caseiro (para mais detalhes consultar seção Materiais e Métodos) e as imagens foram obtidas com um aparelho ImageQuant LAS 500 (GE Healthcare, Little Chalfont, UK)

A seguir foram adaptados uma série de experimentos a fim de avaliar as funções efetoras das células NK.

\subsection{Ensaios para avaliação das funções efetoras de células NK}

Sobre o ensaio de contato entre células alvo e efetoras, nós avaliamos a formação de conjugados por até 240 minutos, coletando amostras a cada 15 minutos. Testamos ainda diferentes concentrações de células efetora/alvo que variaram de 1:2, 1:4, 1:6, 2:1, 4:1 e 6:1 (o protocolo completo pode ser encontrado na seção Materiais e Métodos), sendo que a 
concentração de uma célula efetora para cada quatro células alvo no tempo de 15 minutos de incubação foi a que se mostrou mais promissora (figura 42).

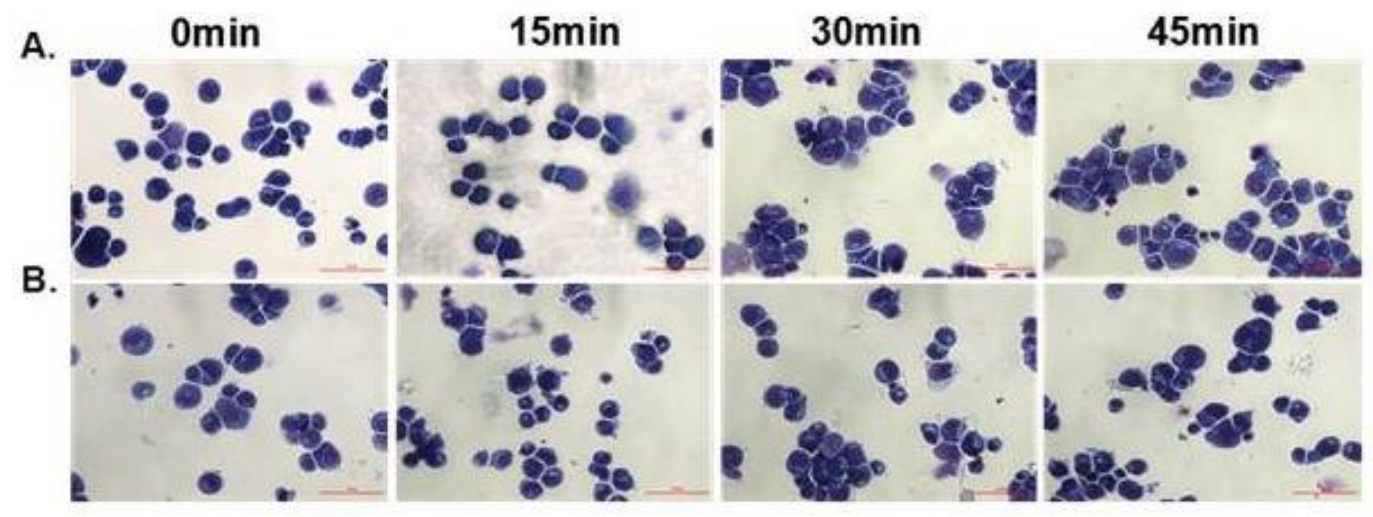

Figura 42 - Cinética para padronização do tempo de contato entre células efetoras YT e células alvo RAJI. Um total de $1 \mathrm{x}$ $10^{5}$ células RAJl e YT foram incubadas em conjunto a $37^{\circ} \mathrm{C}$ nas concentrações célula alvo/célula efetora 1:2 (A) ou 1:4 (B) em diferentes tempos $(0,15,30$ ou 45 minutos) e, em seguida, transferidas para câmara de cytospin e foram citocentrifugadas. As lâminas foram coradas com o kit InstantProv (Newprov) e fotografadas em microscópio de luz em aumento $40 \mathrm{X}$.

A análise dos gráficos dos experimentos avaliando a quantidade de lisossomos nos permite inferir que as quatro concentrações testadas apresentam um bom grau de marcação, o que pode ser observado pela distância no gráfico entre a fluorescência das células não marcadas e as células marcadas. Nenhuma diferença foi notada também entre os dois tempos de incubação testados. Sendo assim, optamos por prosseguir os experimentos utilizando a concentração de $12 \mathrm{~nm}$ com 1 hora de incubação (figura 43).

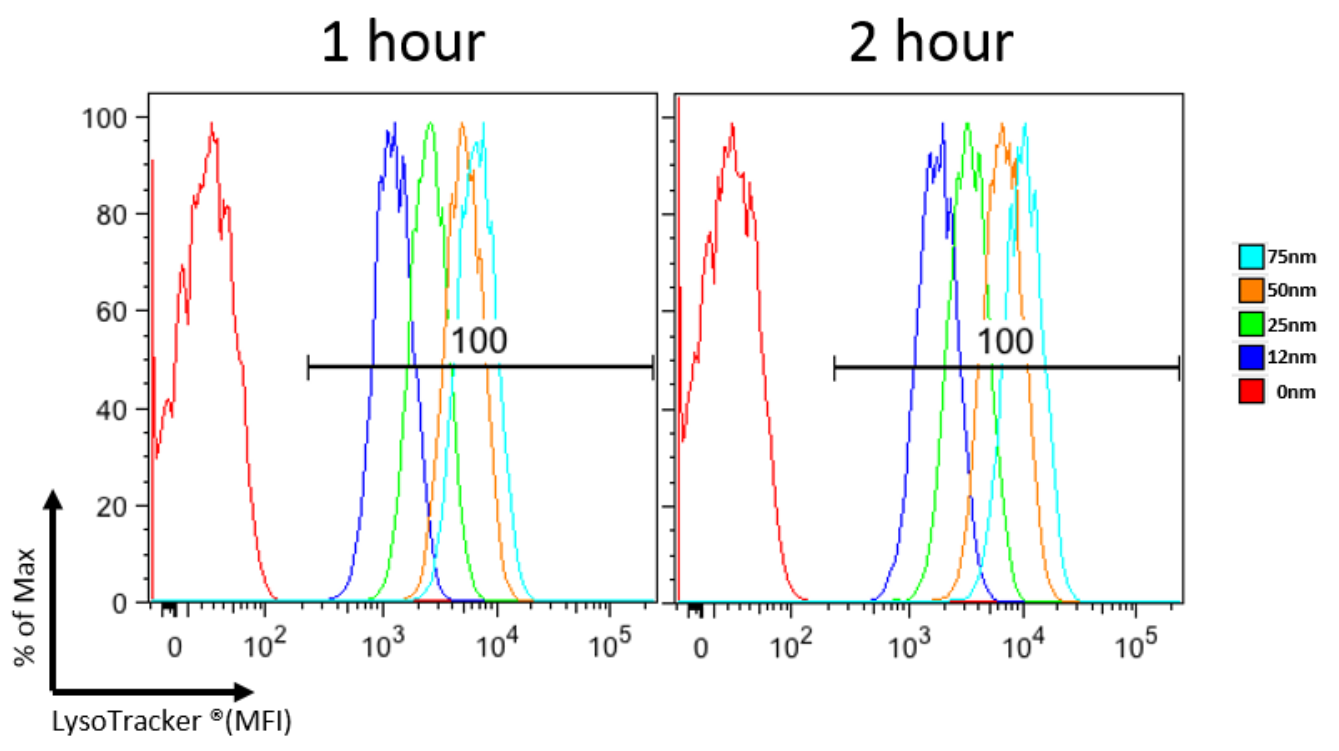

Figura 43 - Padronização do marcador de lisossomos LysoTracker ${ }^{\circledR}$ para análise da população de lisossomos. No experimento foram testados dois tempos diferentes de incubação com o corante (1 hora (esquerda) e 2 horas (direita)) e quatro concentrações diferentes (12,5 nM (azul); $25 \mathrm{nM}$ (verde); $50 \mathrm{nM}$ (laranja); $75 \mathrm{nM}$ (azul claro)) do reagente em células 
YT. As amostras foram analisadas por citometria de fluxo no FACS CANTO II (BD Biosciences). No gráfico são exibidas as médias de intensidade das fluorescências.

Outro experimento adaptado foi o ensaio para ativação de células NK e linfócitos T CD8. O objetivo desse experimento é fornecer uma ferramenta para avaliar a dinâmica de receptores celulares e quimiocinas nesses tipos celulares. A metodologia pode ser vista em detalhes na seção Materiais e Métodos e informações acerca da estratégia de gate utilizada para analisar o experimento pode ser vista na figura 44. Em resumo, configuramos a nossa análise eliminando a presença de doublets (duas células que são lidas ao mesmo tempo pelo citômetro), em seguida eliminamos da análise os debris celularesselecionando somente as células vivas com base na marcação negativa para LIVE/DEAD ${ }^{\circledR}$ (Invitrogen) e por fim, fizemos o FMO (todas as marcações menos a de interesse) para cada uma das marcações do nosso experimento.
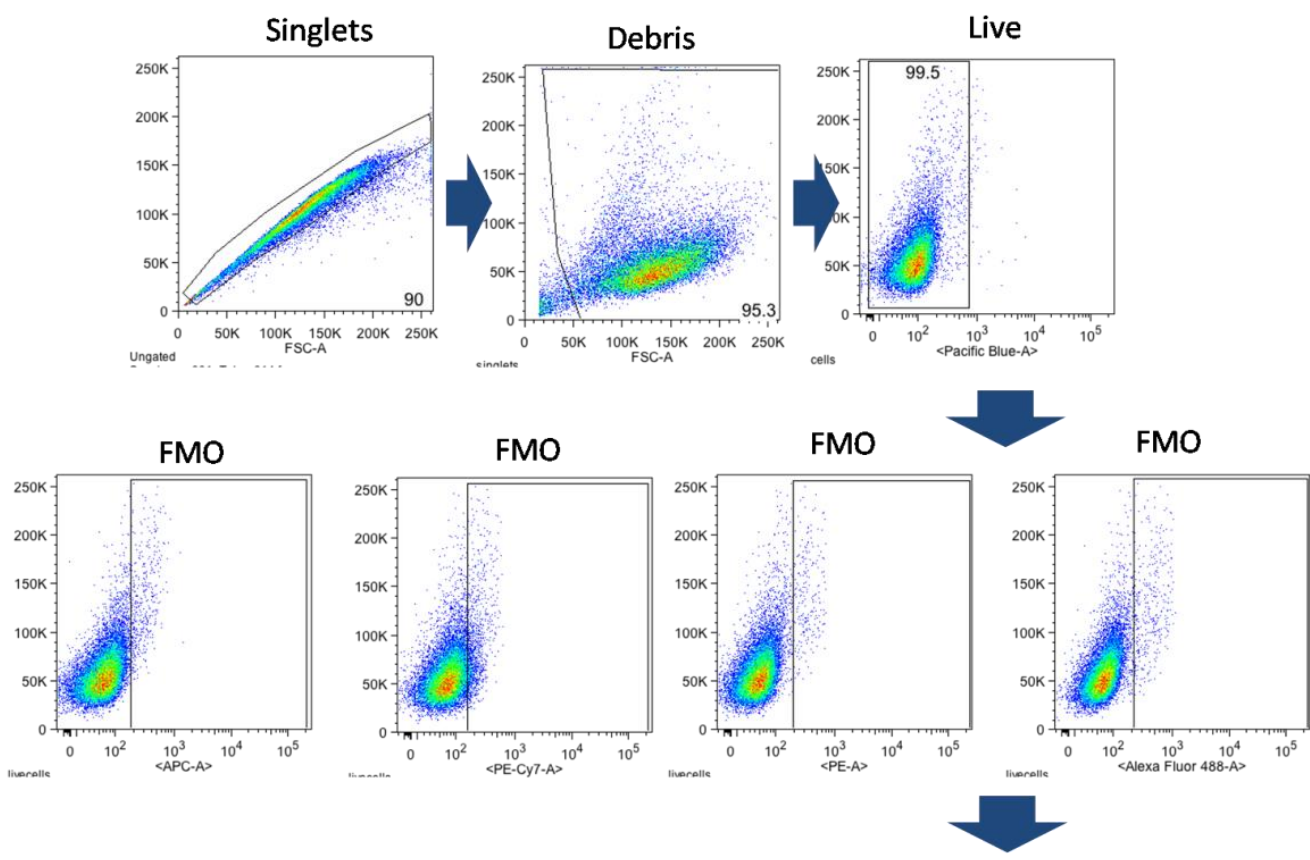

Frequency of positive cells

Figura 44 - Estratégia de gate utilizada na análise do experimento de ativação de células NK. Foram eliminados da análise os doublets e os debris celulares e a análise foi feita somente com as células vivas. Controles FMO foram feitos para todos os parâmetros avaliados. 20.000 células foram analisadas em cada condição.

Com base nos dados obtidos e transformados em gráficos de barra (figura 45), podemos observar algo muito interessante, que diferentes estímulos de ativação provocam diferentes reações por parte da célula. Um exemplo disso é que a ativação com PMA/IONOMICINA provoca um aumento nos níveis de CD25, porém, não estimula a expressão na membrana de CD40L e CD69. Além disso, podemos observar que a célula sem 
soro parece descontrolar a expressão dos receptores na superfície, provavelmente porque essas células devem estar entrando em apoptose e por isso perdem esse controle. Os dados sobre INF- $\gamma$ foram excluídos da análise porque tivemos algum problema com a marcação, ficando negativa em todos os casos.
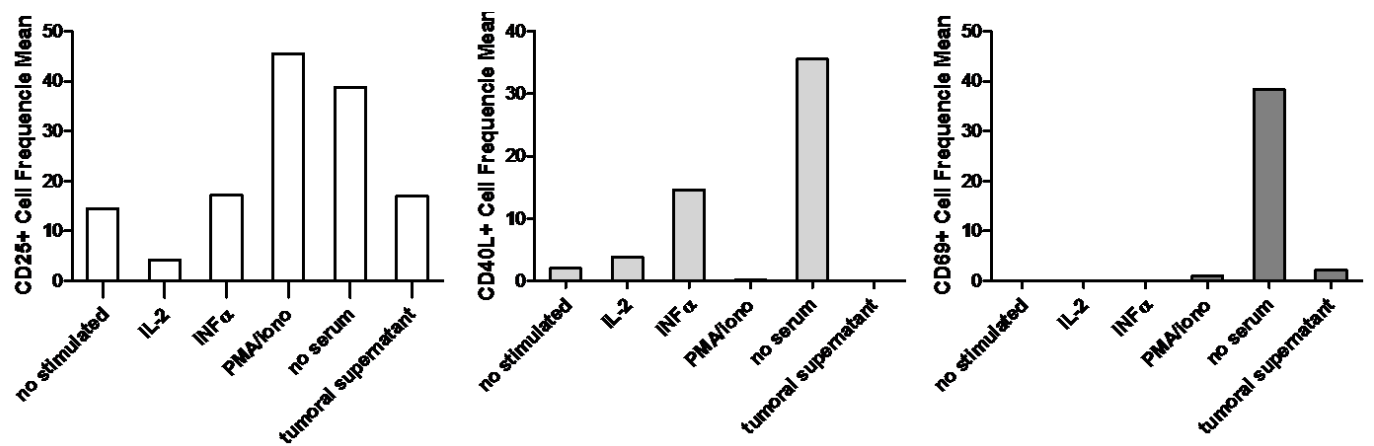

Figura 45 - Gráficos das médias das frequências de células positivas para os marcadores de ativação CD25, CD40L e CD69 em células NK submetidas ao ensaio de ativação e avaliadas por citometria de fluxo. 20.000 células foram analisadas em cada condição.

A qPCR, também chamada de real-time PCR, tem sido uma das técnicas mais utilizada por cientistas de diversas áreas do conhecimento e o avanço e popularização dessa técnica tem tornado cada vez mais simples e barato realizar análises da expressão gênica. No nosso trabalho, esta técnica também foi utilizada para avaliar diferenças na expressão de algumas RABs entre linfócitos T CD8 naïve e ativados.

Nesses experimentos optou-se por trabalhar com SYBRGreen, visto que esta é uma plataforma já bastante consolidada no nosso laboratório. Para tanto, foram encomendados primers específicos para as RABs deste estudo, tanto para humanos como murinos. Utilizando protocolos descritos na seção Materiais e Métodos (geração de blastos de linfócitos T CD8 e separação magnética), nós realizamos um experimento em que avaliamos se existem diferenças na expressão de RAB2A, RAB5A, RAB17 e RAB27A entre células não estimuladas e células estimuladas em cultura com anticorpo anti-CD3. Os resultados podem ser vistos abaixo. As análises a RAB5A, RAB17 e RAB18 foram incluídas neste experimento por (figura 46). 


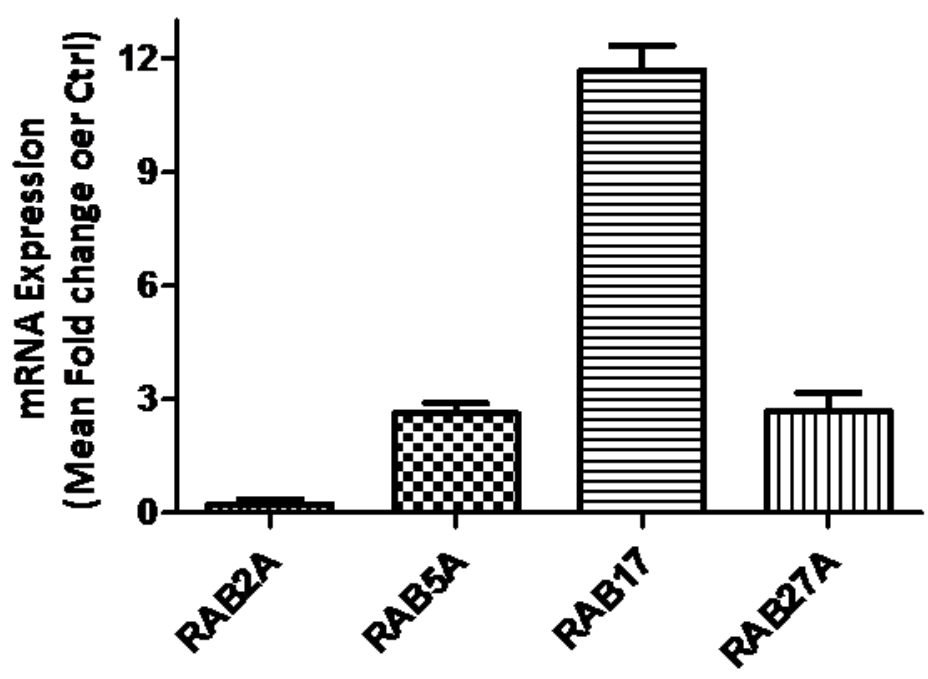

Figura 46 - Análise por RT-PCR (qRT-PCR) da expressão do mRNA de Rab2A, Rab5A, Rab17 e Rab27A em linfócitos T CD8 exvivo ativados. Os mRNA de linfócitos T CD8 purificados tratados ou não com anticorpos anti-CD3 foram analisados por qRTPCR para expressão de Rab2A, Rab5A, Rab17 e Rab27A após 16 horas em cultura à $37^{\circ} \mathrm{C}$ e $5 \% \mathrm{CO}_{2}$. As amostras não tratadas com anti-CD3 foram utilizadas como controle da expressão dessas proteínas. O gene da beta actina foi utilizado como controle housekeeping neste experimento. 


\section{DISCUSSÃO}

Isoformas estruturalmente relacionadas de membros da superfamília Ras são frequentemente encontrados e podem compartilhar facilmente $80-90 \%$ de similaridade. Subgrupos de proteínas homólogas também existem entre membros da subfamília Rab (124). Um exemplo disso são as isoformas da RAB1: RAB1A e RAB1B. Essas duas proteínas estão presentes nos compartimentos intermediários do Golgi e desempenham um papel semelhante no controle do transporte do retículo endoplasmático para o Golgi (125). Entretanto, o compartilhamento de sequências homólogas não necessariamente implica que as proteínas executem as mesmas funções, como é o caso da RAB3. O subgrupo da RAB3 é formado por RAB3A, RAB3B, RAB3C e RAB3D e compartilham de 77-85\% de similaridade. A RAB3A e RAB3C são expressas em neurônios e juntas regulam a liberação de neurotransmissores (126). Já a RAB3B é expressa por células epiteliais e é uma importante molécula sinalizadora das vias de exocitosenessas células. Por fim, a RAB3D foi encontrada em adipócitos e parece estar envolvida no transporte de vesículas contendo GLUT-4 (127).

Pesquisadores que caracterizaram a RAB5 em células de mamíferos demonstraram que a RAB5B e RAB5C apresentam $88 \%$ e $91 \%$ de similaridade com a RAB5A, respectivamente, além de apresentarem expressão e distribuição semelhante nos tecidos. Mais ainda, as três isoformas compartilham a habilidade de regular o transporte no início da via endocítica. A presença de três isoformas da RAB5 parece refletir uma necessidade evolutiva a fim de assegurar o funcionamento desta proteína. Por outro lado, cada isoforma poderia desempenhar um papel distinto e exercer um controle fino da via endocítica (128).

Em 1989 o gene humano rab2 foi isolado pela primeira vez. Junto a este, foram isolados também os genes rab1, rab3a e rab3b, rab4, rab5 e rab6. 0 estudo precursor demonstrou que rab2 possui 212 aminoácidos e massa molecular de 23,632 Da, além de compartilhar por volta de $98 \%$ de similaridade com o produto murino (129).O grupo de Marino Zerial demonstrou na mesma época, utilizando técnicas de microscopia confocal e eletrônica, que a RAB2 estava associada aos compartimentos intermediários da rota entre o retículo endoplasmático e o Golgi em células de mamíferos, sugerindo que ela atua de alguma maneira no início da via exocítica (130). 
Estudos mostraram ainda que existem duas isoformas da RAB2A: RAB2A isoforma a e RAB2A isoforma b. A isoforma a consiste no transcrito predominante e codifica uma isoforma maior. Já a isoforma b não possui um exon in-frame na região codificadora 5', resultando em uma variante menor que não possui um segmento interno da proteína.

Em 1992, outro grupo examinou o papel da RAB2 in vivo utilizando vírus vaccínia como sistema de expressão transiente a fim de expressar mutantes de RAB. Esse grupo forneceu evidencias da participação da RAB2 na regulação da maquinaria celular envolvida na fissão e fusão de vesículas das vias de transporte entre o retículo endoplasmático e o Golgi (125). Estudos mais aprofundadosdo mesmo grupo demonstraram que a extremidade N-terminal da RAB2 é necessária para o funcionamento desta proteína, visto que deleções em resíduos nessa região resultam em perda de atividade in vivo. Além disso, dados morfológicos e bioquímicos sugerem que a RAB2 pode estar envolvida na montagem ou maturação dos intermediários pré-Golgi numa etapa anterior a fusão de vesículas dependente de cálcio no compartimento cis do Golgi(131).

Diversas são as isoformas de RABs presentes no Golgi de mamíferos e que participam da regulação de sua morfologia, entretanto, a relação se essas proteínas são funcionalmente redundantes ou se atuam de maneira diferente ainda é pouco conhecida. Em um artigo publicado recentemente, um grupo mostrou que a redução da expressão de RAB1A, RAB1B, RAB2A, RAB2B, RAB6B ou RAB8A, independentemente, causa a fragmentação do Golgi em células Hela, apesar destas proteínas serem altamente homólogas entre si. Um exemplo disso é que o silenciamento gênico da RAB2A em células Hela-S3 leva a fragmentação do Golgi. Este efeito, porém, pode ser revertido quando a expressão gênica dessa proteína é resgatada pela re-expressãoda mesma. Por outro lado, esse efeito não era observado quando os pesquisadores re-expressavam RAB1A, RAB1B, RAB6B, RAB8A ou até mesmo RAB2B em células Hela-S3 RAB2A nocaute, indicando que essas proteínas participam da regulação da morfologia do Golgi de maneira não redundante (132).

Ellen J. Tisdale é sem dúvidas uma autoridade quando o assunto é RAB2. Em uma série de artigos publicados nos anos 2000 , ela e seu grupo dissecaram o funcionamento da RAB2. Em um estudo de 2009 seu grupo demonstrou que a RAB2 utiliza GAPDH (do inglês, glyceraldehyde-3-phosphate dehydrogenase) e uma proteína quinase atípica (aPKC1), que 
interagem com a região amino-terminal da RAB2 para se associar a microtúbulos e recrutar dineína, sugerindo um mecanismo pelo qual a RAB2 é capaz de controlar o recrutamento de microtúbulos aos aglomerados tubulares vesiculares (do inglês, vesicular tubular clusters) (133).

Em 2002 foi publicado um artigo com a clonagem do gene rab2b, homólogo do gene murino rab2 e do gene rab2a humano. Análises de bioinformática mostraram que o rab2b compartilha um alto grau de homologia com o gene humano e murino, $83 \%$ e $82 \%$, respectivamente. 0 gene localiza-se na região14q11.2, enquanto o rab2a está localizado no 8q12.1. Além disso, os pesquisadores avaliaram os padrões de expressão desse gene e encontraram indícios nos rins, próstata, pulmão, fígado, timo e cólon, além de uma baixa expressão na placenta, pâncreas, e músculo esquelético (134).

Estudos buscando novos alvos que participam de mecanismos moleculares de transporte em lisossomos não são uma novidade. Nesses estudos, a técnica de proteômica é amplamente utilizada, como pode ser observado em um estudo de 2005 , no qual diversas moléculas foram descritas em lisossomos de ratos e revelaram uma composição bastante diversificada (135). Mais tarde, outro grupo identificou um grande número de novas proteínas nunca antes reportadas em lisossomos humanos, desta vez relacionadas com a membrana desta organela, além de um grande número de outras proteínas previamente identificadas (136). Em ambos os estudos foi encontrada a proteína RAB2A, porém, nenhum detalhe acerca da função desta proteína foi mencionado em nenhum artigo.

Técnicas de proteômica são poderosas metodologias utilizadas no screening de novos alvos ou moléculas envolvidas em processos biológicos. Com um único experimento de proteômica é possível identificar até 5000 proteínas diferentes, embora rotineiramente esse número seja muito menor. O gel de eletroforese em duas dimensões (2-DE) com um gradiente de $\mathrm{pH}$ imobilizado associado a espectrometria de massa para identificação das proteínas é atualmente a técnica mais utilizada em estudos desse tipo. Essa metodologia permite a separação de misturas complexas de acordo com o ponto isoelétrico, da massa molecular, da solubilidade e até da abundância das proteínas na amostra. Essa técnica é uma técnica muito eficiente para deteç̧ão de proteínas com alta expressão na célula $\left(10^{5}-10^{6}\right.$ cópias/célula), entretanto, proteínas mais raras (menos de 100 moléculas/células) 
normalmente não são detectadas por esta metodologia, sendo necessário o emprego de outras técnicas (137).

A apoptose (morte celular programada) é um processo de fundamental importância para o desenvolvimento e homeostasia dos organismos multicelulares e estudos de proteômica frequentemente têm ajudado a revelar muitas das proteínas envolvidas neste processo (138 e 139). Estudos de proteômica de grânulos citotóxicos, entretanto, tem sido muito menos frequentes, e são escassos na literatura. O primeiro estudo de proteômica de grânulos citotóxicos com células NK humanas foi publicado recentemente (140) e somente em 2011 foi publicado o primeiro estudo completo contemplando uma análise de proteômica de grânulos citotóxicos de linfócitos T CD8 humanos (141).

Embora a análise dos grânulos citotóxicos por meio de técnicas de proteômica seja uma ferramenta valiosa para analisar a composição e função dessas organelas, a técnica em si apresenta alguns problemas e limitações. Um exemplo disso é que apesar do processo de separação dos grânulos ter sido feito de acordo com o protocolo, podemos observar na lista de proteínas encontradas neste trabalho moléculas que sabidamente fazem parte de outras organelas, como é o caso da BiP/GRP70, uma chaperona típica de retículo endoplasmático (a lista completa com todas as proteínas encontrada no estudo de proteômica que deu origem a este trabalho pode ser encontrada nos Apêndices I e II). Esse é um problema comum entre aqueles que utilizam esta metodologia e uma possível explicação para isso é que a fração correspondente aos grânulos citotóxicos possa ter sido contaminada com outras organelas ou pedaços de membranas de outras organelas durante a centrifugação.Sendo assim, como acontece em todo experimento de screening de larga escala, os dados de proteômica devem ser validados para que possamos afirmar sem sombra de dúvida que uma proteína está presente em determinada organela.

Duas grandes classes de cientistas têm participado ativamente dos estudos das organelas celulares: Os bioquímicos e os biologistas celulares. Os primeiros, tem se especializado no rompimento de células para separar as organelas por técnicas clássicas como a centrifugação diferencial por gradiente, a fim de caracterizar propriedades químicas, físicas ou enzimáticas das organelas. Já o segundo grupo tem se valido de corantes e métodos ópticos para definir padrões morfológicos distintos dos objetos estudados. Um 
terceiro grupo de cientistas tem surgido nos últimos tempos, valendo-se de uma visão mais holística, integrando modernas técnicas de proteômica com conceitos clássicos de bioquímica e biologia celular. A peça central por trás desse novo conceito científico tem sido a utilização de técnicas de imunofluorescência associadas ao uso de marcadores clássicos de compartimentos celulares (142).

Nesse universo, o microscópio confocal tem sido utilizado pela comunidade científica para superar problemas encontrados há anos por bioquímicos e biologistas celulares, dentro os quais podemos destacar a falha na identificação de proteínas e/ou atribuição incorreta de contaminantes presentes nas amostras. As análises de microscopia confocal fornecem uma evidência direta da localização subcelular das proteínas estudadas e têm sido utilizadas nos estudos dos mais variados compartimentos celulares (143-145).

O avanço tecnológico tem enriquecido ainda mais esse tipo de análise com o advento de novas tecnologias que permitem a geração de imagens com qualidade superior, imageamento in vivo e time-lapse, desenvolvimento de novos marcadores e corantes cada vez menos tóxicos, mais estáveis e mais específicos, linhagens celulares expressando proteínas fluorescentes, técnicas que permitem observar a interação de proteínas, imageamento em larga escala, reconstruções tridimensionais dos objetos estudados, etc... (146).

A microscopia confocal é, portanto, uma ferramenta robusta e que fornece informações ricas e precisas acerca da localização subcelular de proteínas, sendo amplamente difundida, utilizada e aceita por aqueles que praticam análises de proteômica. Com base no exposto acima, nosso grupo adotou esta metodologia para validar inicialmente os dados da proteômica.

Embora a técnica apresente muitas vantagens, conforme discutido anteriormente, os protocolos não são simples, demandam muito tempo e são laboriosos. Além disso, foi necessário o desenvolvimento de uma plataforma completamente nova no nosso laboratório para realização deste tipo de análise, sendo necessária a aquisição de muitos reagentes e padronizações extensivas, bem como dezenas de horas em frente ao microscópio confocal. 
Os primeiros passos para geração das imagens foram as padronizações dos anticorpos primários utilizados neste estudo (o protocolo em detalhes pode ser encontrado na seção Materiais e Métodos, assim como os reagentes utilizados). Nós realizamos a padronização dos anticorpos, isso quer dizer, encontramos a concentração ideal para se trabalhar com os anticorpos primários e secundários, de maneira que cada um deles gere uma intensidade ótima de sinal (fluorescência) que seja capturada pelo microscópio. Foram feitas padronizações dos anticorpos contra RAB2A (figura 12), RAB5A (figura 13), RAB17 (figura 14), RAB18 (figura 15), LAMP-1 (dados não mostrados), LAMP-2 (dados não mostrados), granzima B (dados não mostrados), perforina (dados não mostrados), Faloidina (dados não mostrados), tubulina (dados não mostrados) e o corante vital para o núcleo Hoechst (dados não mostrados).

Os dados das padronizações indicam a presença de todas as RABs analisadas nas células YT. Entretanto, análises mais detalhadas, baseadas na colocalização das RABs com moléculas da superfície dos lisossomos (LAMP-1 e LAMP-2) e moléculas do lúmen (granzima B e perforina), forneceram informações mais precisas acerca da localização subcelular dessas proteínas.

O estudo da proteína RAB5A revelou que a mesma provavelmente não está presente nos grânulos citotóxicos das células (figura 16) YT. A análise das imagens em conjunto nos leva a crer que a RAB5A não está presente nos grânulos. Entretanto, confirmamos a existência dessa proteína nas células YT, provavelmente associada aoutro compartimento celular. As imagens da colocalização da RAB5A com LAMP-2 não ficaram boas e por isso foram eliminadas deste manuscrito.

A análise dos resultados obtidos a partir da imunomarcação da RAB17 e LAMP-1, LAMP-2, granzima B e perforina por microscopia confocal de fluorescência (figura 18) nos permitiu concluir que esta proteína também está presente nas células $\mathrm{YT}$, porém, assim como aconteceu com a RAB5A, ela não está presente nos grânulos citotóxicos dessa linhagem celular. Mais uma vez tratamos isso como fruto de contaminação da proteômica, provavelmente devido a fragmentos de membrana de outras organelas presentes no material analisado. 
Assim como aconteceu com os experimentos utilizando anticorpos para RAB5A e RAB17, a presença da RAB18 foi considerada um artefato da técnica de separação celular utilizada nos experimentos que deram origem a este trabalho. Novamente confirmamos a presença desta proteína nas células YT (figura 20), porém, provavelmente em um contexto diferente do que está sendo abordado neste estudo.

Diferentemente do que aconteceu com as demais proteínas, a análise das imagens dos experimentos utilizando a marcação da proteína RAB2A e quatro diferentes proteínas presentes nos lisossomos nos levou a concluir que a RAB2A está presente nos grânulos citotóxicos da linhagem celular YT, devido ao alto grau de colocalização evidenciado nas imagens (figuras 22-25 e figura 26). Além disso, a análise estatística do grau de colocalização da RAB2A associada às proteínas do lisossomo indicam que a RAB2A provavelmente esteja associada a proteínas da membrana do grânulo como LAMP-1 e LAMP-2 (figura 28).

A metodologia utilizada nesta primeira fase é muito robusta e forneceu subsídios suficientes para dizer que a RAB5A, RAB17 e RAB18 não estão presentes nos grânulos citotóxicos, apesar de confirmarmos sua existência na linhagem celular utilizada. Uma segunda abordagem na qual utilizamos técnicas de microscopia eletrônica de transmissão foi utilizada para reforçar os nossos resultados acerca da localização da RAB2A.

Uma vez que o objetivo deste projeto é o estudo das proteínas RAB2A, RAB5A, RAB17 e RAB18 nos grânulos citotóxicos, e, que somente a RAB2A foi observada nesses compartimentos utilizando microscopia confocal, o foco do estudo foi mantido e o estudo da RAB5A, RAB17 e RAB18 foi deixado de lado para que toda a nossa atenção fosse voltada para o estudo da RAB2A. A fim de validar os dados da proteômica e dos estudos de microscopia confocal acerca da RAB2A, utilizamos a técnica padrão ouro para a determinação da localização celular de proteínas: a microscopia eletrônica de transmissão (MET).

As técnicas utilizadas no preparo das amostras para microscopia eletrônica seguem os mesmos princípios das técnicas utilizadas na microscopia de luz. Em geral, a identificação de um antígeno é precedida pela marcação com um anticorpo contra a proteína alvo do estudo e a visualização dessa proteína dá-se por meio da utilização de anticorpos secundários conjugados com metais pesados, sendo o mais comum o ouro, que refletem os 
elétrons incidentes. Esta técnica permite a distinção de organelas baseada na morfologia, características intrínsecas das organelas, ou por meio da utilização de anticorpos contra proteínas típicas das organelas (147).

A microscopia eletrônica tem se tornado uma ferramenta essencial nos estudos de compartimentos intracelulares como lisossomos, bem como no funcionamento dessas organelas (148 e 149), além de ser amplamente utilizada em estudos de tráfico intracelular (150). Esses estudos requerem a preservação das estruturas e da reatividade dos antígenos, fatores limitantes para o sucesso da técnica. Atingir isso, porém, não é trivial e permanece como um dos grandes obstáculos para se trabalhar com essa técnica (151).

Durante os quatro anos do doutorado nós lidamos com a dificuldade de realizar experimentos utilizando microscopia eletrônica. Nosso grupo inclusive recorreu a outros grupos especializados nesta metodologia. Após muitas tentativas frustrantes e com a aquisição de novos reagentes nós utilizamos um protocolo que desenvolvemos em conjunto com o grupo da Profa. Dra. Telma T. Zorn, do Departamento de Biologia Celular e do Desenvolvimento do Instituto de Ciências Biomédicas (ICB-USP), e que pode ser encontrado na seção Materiais e Métodos. Como pode ser visto na figura 29, os resultados encontrados corroboram com nossos dados anteriores, podendo ser vista a marcação da RAB2A espalhada pelo citoplasma, assim como em organelas eletrondensas que acreditamos serem lisossomos.

Juntos, os dados de proteômica, microscopia confocal e microscopia eletrônica não deixam qualquer dúvida acerca da localização da RAB2A. Com isso, nossa conclusão parcial até este momento é que a RAB2A está presente em grânulos citotóxicos de células YT. Nosso próximo passo foi desenvolver uma ferramenta para diminuir a expressão gênica, ou, o que é mais desejável, silenciar por completo a expressão dessa proteína. Para isso, empregamos técnicas como shRNA e posteriormente CRISPR/CAS9.

Em 1998, Fire, Mello e colaboradores publicaram um trabalho seminal que trouxe grandes avanços na pesquisa básica e translacional, tornando se um dos artigos mais citados da história da biologia. Nesse artigo, os cientistas revelaram em Caenorhabditis elegans uma via de silenciamento gênico pós transcricional desencadeada por RNAs de fita dupla (dsRNA) (152). Após esse estudo, uma série de outros estudos surgiu elucidando a via do RNA de 
interferência (RNAi), assim como seu papel biológico. Atualmente, os small interference RNA (siRNA) e os short hairpin RNA (shRNA) codificados por vírus e plasmídeos são ferramentas amplamente utilizadas por biologistas a fim de realizar o silenciamento gênico pós transcricional, sendo considerados uma técnica indispensável para a pesquisa biológica moderna e médica (153).

De forma resumida, o que acontece dentro da célula é que o siRNA é processado pela enzima Dicer e outras proteínas associadas, de maneira que este se torna um siRNA de aproximadamente 21 nucleotídeos. Uma das fitas (fita guia) é então integrada ao complexo RISC (do inglês, RNA-induced silencing complex), cujo componente central é a Ago2. A outra fita é degradada. O siRNA acoplado à fita guia alcança o mRNA alvo por meio de complementaridade, e desencadeia a clivagem do mesmo pelo complexo RISC (154). Após a clivagem, o mRNA alvo perde alguns elementos necessários para sua estabilização e rapidamente o mRNA é degradado por RNAses, e por isso a proteína que seria codificada não pode mais ser sintetizada.

O silenciamento gênico de um alvo com shRNA, entretanto, é transiente e dura normalmente entre cinco e sete dias. A degradação da sequência alvo inicia-se imediatamente após o siRNA entrar na célula, porém, a diminuição dos níveis da proteína de interesse vai depender da meia vida dela. Em geral, este efeito pode começar a ser observado 48 horas após a transfecção, entretanto, algumas proteínas têm uma taxa de turnover muito baixa, e por isso a proteína pode permanecer na célula por muito mais tempo (155). Não encontramos na literatura se isso foi determinado no caso RAB2A e até o momento não sabemos se esse tempo é suficiente para degradação da nossa proteína.

A utilização de vetores lentivirais portadores de sequências shRNA tem sido utilizada para aumentar a duração do silenciamento gênico em células primárias e por isso foi escolhida para esta etapa do estudo. Além disso, está bem descrito na literatura que os lentivírus são capazes de transduzir tanto células quiescentes quanto células em proliferação e possuem um potencial oncogênico menor do que outros vetores (156).

Um dos grandes desafios dessa técnica é desenhar sequências que sejam específicas para o mRNA de interesse sem que haja efeitos off-target (inespecíficos) e que ao mesmo tempo, o shRNA tenha níveis desejado (os maiores possíveis) de eficiência de silenciamento 
(157). Foi por este motivo que escolhemos quatro sequências diferentes para RAB2A neste estudo, uma vez que não está descrito na literatura o melhor alvo para o silenciamento desta proteína.

Apesar de todos os nossos esforços e ajustes nos protocolos de geração de blastos e também no protocolo de transdução, as células primárias utilizadas nos experimentos morriam antes de 13 dias após o início do protocolo (dados não mostrados), não sendo possível obter células em termos de quantidade ou de viabilidade, sendo, portanto, necessário escolher outra abordagem para o silenciamento gênico.

Foi nesse contexto e a fim de atender uma demanda do nosso projeto que surgiu a oportunidade de trabalhar com uma técnica mais moderna e promissora intitulada CRISPR/CAS9. CRISPR é a sigla para a frase do inglês Clustered Regularly Interespaced Short Palindromic Repeats. A via do CRISPR foi identificada originalmente no genoma da bactéria Escherichia coli (E. coli), onde ela funciona como um braço da imunidade que luta contra vírus invasores. Nesses organismos, pequenas sequências de DNA dos vírus são incorporados ao loci do CRISPR no genoma bacteriano, funcionando como uma espécie de "memória imunológica", protegendo a bactéria de infecções subseqüentes. Reinfecções fazem com que o CRISPR maduro seja ativado, de maneira a encontrar a sequência correspondente, fornecendo a nuclease associada ao CRISPR - Cas (do inglês, CRISPR-associated (Cas) nuclease) especificidade para quebrar as duplas hélices em regiões específicas do DNA estranho. Cientistas adaptaram o CRISPR a fim de utilizar este como uma ferramenta para edição de alvos no genoma. Esta ferramenta tornou-se popular recentemente devido a simplicidade e versatilidade que apresenta (158).

A nuclease Cas9 é guiada nas bactérias pelos RNA complementar maduro do CRISPR (crRNA) e RNA complementar maduro trans-ativador do CRISPR (tracrRNA), de maneira a clivar sequências específicas no DNA estranho. Além disso, a clivagem pela Cas9 somente ocorre quando existe uma sequência PAM (sigla do inglês para protospacer-adjacent motif) ao redor da sequência alvo do DNA invasor (159).Alguns RNA guia (gRNA) foram desenvolvidos e validados a fim de imitar o complexo crRNA- tracrRNA com o auxílio de ferramentas de bioinformática disponíves online (figuras 34 e 35). 
Em cada etapa do protocolo foram incluídos checkpoints a fim de assegurar a qualidade dos experimentos envolvendo o CRISPR. O primeiro deles foi o uso de uma ferramenta de bioinformática para avaliar a similaridade e existência degaps entre as sequências geradas e asequência FASTA da RAB2A, incluindo suas duas variantes (figura 36); a PCR de colônia que foi feita após a transformação bacteriana e que forneceu subsídios para selecionar somente os clones de interesse para o experimento; o sequênciamento realizado para garantir que os gRNA encontravam se nos plasmídeos produzidos(figuras 37 e 38); um controle da eficiência da transfecção ao longo do tempo utilizando um gene repórter foi incluído e ajudou a escolher o tempo em que mais partículas virais parecem estar sendo produzidas e por fim, um controle para avaliar o silenciamento gênico através da técnica clássica de western blot.

A baixa eficiência encontrada nos experimentos de transdução observada através do resultado de western blot quando analisamos as bandas correspondentes a RAB2A transduzidas com gRNA-2 (aparentemente a transdução com gRNA-1 não funcionou) (figura 41) não é uma exclusividade do nosso grupo. Pesquisadores reportaram que células NK em repouso são difíceis de ser transduzidas com vetores lentivirais, mesmo valendo-se de altas multiplicidades de infecção (MOI), com eficiências de transdução que variam entre 3-14\% (160), podendo ser ainda necessários múltiplos rounds de transdução ou então protocolos de enriquecimento celular pós transdução. A transfecção em longo prazo em células NK sem alteração das funções normais fenotípicas e funcionais provou-se ainda mais difícil por meio dos métodos genéticos tradicionais

Essa baixa eficiência de transdução das células NK (quando comparadas com linfócitos $T$, que respondem muito bem a esse tipo de abordagem) não é uma surpresa visto que essas células estão entre as primeiras que respondem a infecções virais e foram selecionadas evolutivamente para ser altamente resistentes a infecções virais. Isso se deve em parte às características intrínsecas das células NK, nas quais se enquadram os bem caracterizados receptores da imunidade inata, como receptores de reconhecimento de padrões que reconhecem materiais genéticos estranhos podendo acarretar a apoptose dessas células (161) . 
Alguns autores tem se valido de estratégias a fim de obter melhores índices de transdução. A adição de IL-2 e IL-12 na cultura estão entre as práticas mais comuns e tem gerado aumentos interessantes na eficiência de transdução (162).Mais recentemente, pesquisadores utilizaram moléculas inibidoras das vias de sinalização de RIG-1, MDA-5 e TLR3 e obtiveram aumentos significativos na eficiência de transdução de células NK primárias derivadas de humanos (163)

A imunoterapia adotiva com células NK geneticamente modificadas, apesar das dificuldades que ainda existem na manipulação desse material, é considerada uma ferramenta promissora para o tratamento de câncer, entretanto, adaptações de maneira que se obtenham altas eficiências de transdução e protocolos gênicos clinicamente aplicáveis ainda são um grande desafio para pesquisadores. (162).

A seguir discutiremos acerca das metodologias adaptadas para avaliar questões acerca das funções efetoras das células NK. O Ensaio de contato entre células alvo e efetorasfoi um dos ensaios adaptados neste trabalho para avaliar a formação de conjugados células efetoras/células alvo, ou seja, com este experimento é possível avaliar a capacidade das células em formar sinapses imunológicas, considerado o primeiro passo no processo efetivo de eliminação de células alvo por células NK e linfócitos T CD8. Dados da literatura sugerem que células citotóxicas podem eliminar seus alvoscom menos de dois minutos, porém, estudos in vitro sugerem que um tempo de pelo menos 30 minutos é necessário para observar a eliminação de células alvo in vitro. Calcula-se que nesse intervalo de tempo um número significativo de células possam alcançar o fundo das placas em que estão sendo realizados os ensaios e que um número suficiente de células citotóxicas possam ter encontrado seus alvos (164).

Embora o ensaio parecesse simples, uma série de complicações sugiram que comprometeram as análises dos resultados. Entre as complicações podemos citar a dificuldade em diferenciar células efetoras próximas de células alvo exercendo atividade citotóxica daquelas que não estavam exercendo atividade citotóxica; Apesar disso, a técnica tem seu valor e junto de outras metodologias pode fornecer informações acerca de umaimportante função efetora das células NK. 
Outro parâmetro importante a ser avaliado acerca da função efetora das células NK é a quantidade de lisossomos presentes nestas células. Uma forma de avaliar isso é através de um ensaio muito simples em que coramos os lisossomos das células com um corante comercial, no caso LysoTracker ${ }^{\circledR}$ (Life Technologies), e avaliamos a média da intensidade de fluorescência das populações celulares estudadas. $O$ corante funciona sobre o princípio de que aminas básicas se acumulam em compartimentos celulares com baixo $\mathrm{PH}$. Com isso em mente, a empresa desenvolveu sondas fluorescentes acidotrópicas capazes de marcar e identificar organelas ácidas, inclusive em células vivas. Esse reagente apresenta várias vantagens, entre elas, baixo custo, protocolo rápido e simples, efetivo em doses muito baixas e possui uma boa resistência à fixação com aldeídos.

A padronização segue uma recomendação do fornecedor porque diferentes tipos celulares podem reagir de maneiras distintas ao corante. Sendo assim, utilizando as células YT testamos quatro concentrações do corante por dois tempos diferentes (o protocolo em detalhes pode ser encontrado na seção Materiais e Métodos) e como resultado encontramos que a concentração de $12 \mathrm{nM}$ com 1 hora de incubação é satisfatória para esse tipo de análise.

Outra importante função a ser analisada é o tráfico e reciclagem de receptores da superfície celular. Um estudo recente mostrou que a RAB7B participa da regulação de receptores do tipo Toll em células da imunidade inata (165). Outros estudos mostraram o envolvimento de algumas RABs com o tráfico de receptores de quimiocinas (166) e outros com as vias de transporte de integrinas (167). Com base nos dados da literatura, decidimos adaptar um ensaio com o intuito de investigar a dinâmica de receptores em células citotóxicas. Para isso criamos uma abordagem experimental in vitro que consiste na ativação das células YT com diferentes estímulos e posterior análise dos receptores na superfície celular por citometria de fluxo. Esse mesmo ensaio pode ser utilizado para avaliar o tráfico de receptores em linfócitos T CD8, substituindo as células NK por linfócitos T CD8 purificados e acrescentando beads contendo anti-CD3 e anti-CD28 (Life Technologies) (dados não mostrados). Outro aspecto que pode ser avaliado com este ensaio é a produção de citocinas, bastando para isso incluir na cultura inibidores do transporte de proteínas (BD GolgiStop ${ }^{\circledR} \mathrm{e}$ BD GolgiPlug ${ }^{\circledR}$ - BD Bioscience), acrescentando algumas etapas para realização do protocolo de marcação intracelular. 
Esse ensaio é bastante versátil e mostrou que ao contrário do que se espera das respostas das células NK, de que estas sejam padronizadas e estereotipadas, as células podem responder de maneiras distintas a diferentes estímulos, como pode ser visto na figura 45. Este experimento permite ainda a inclusão de diferentes marcadores sejam eles para receptores, quimiocinas ou citocinas, podendo ampliar o espectro da análise.

Por fim, o último experimento apresentado refere-se a uma PCR em tempo real na qual comparamos a expressão da RAB2A, RAB5A, RAB17 e RAB27A entre linfócitos T CD8 murinos em repouso e linfócitos T CD8 ativados. A análise do gráfico nos permite fazer observações importantes (figura 46). A primeira delas, é que para nossa surpresa não houve praticamente nenhuma mudança nos níveis de expressão do mRNA da RAB2A entre as células naïve e ativadas. Esse resultado é bastante inesperado, visto que nós temos acreditado ao longo do projeto que a RAB2A estava envolvida em alguma função efetora das células citotóxicas, e era esperado que houvesse um aumento da expressão gênica dessa proteína ou até mesmo a diminuição, porém, ao contrário de nossas expectativas, esses níveis se manter.

A diferença mais expressiva aparece na RAB17, cuja diferença foi maior que 10 vezes na célula ativada. Podemos notar também um aumento na expressão da RAB5A e da RAB27A, esta última foi introduzida como controle para o experimento, uma vez que é bem descrito na literatura que linfócitos T CD8 ativados aumentam a expressam de RAB27A. Os dados da expressão de RAB18 foram excluídos porque parece haver algum problema com o primer, visto que observamos um sinal positivo no nosso controle da reação contendo água ao invés de cDNA.

Esses resultados são um forte indicio da participação dessas moléculas na função efetora das células citotóxicas, participando não somente da biologia dos grânulos citotóxicos mas também de outras funções celulares que carecem de maiores estudos para serem melhor detalhadas tanto acerca da sua localização quanto de suas funções. 


\section{CONCLUSÕES}

Nos últimos anos, tem havido um interesse crescente pelos mecanismos moleculares por trás das vias de tráfico intracelular. Entretanto, existe uma quantidade limitada de informações acerca das proteínas ou complexosprotéicos envolvidos nos processos de tráfico de grânulos citotóxicos em células NK e linfócitos T CD8. Os dados apresentados neste estudo fornecem evidências da participação de uma nova molécula nessas vias. Estudos iniciais de proteômica foram validados por técnicas de microscopia confocal e microscopia eletrônica,e confirmaram a presença da proteína RAB2A como membro integrante da membrana de grânulos citotóxicos de uma linhagem celular humana de células natural killer. Esses estudos confirmaram também a presença de outras três proteínas dessa família, RAB5A, RAB17 e RAB18 nessa mesma linhagem celular, porém, essas proteínas não se encontram presentes nos grânulos citotóxicos. A ferramenta de edição genômica CRISPR/CAS9 pode ser uma alternativa às metodologias de silenciamento gênico tradicionais tendo em vista a baixa eficiência destas. A inclusão de etapas adicionais como a clonagem de células únicas provenientes do protocolo de CRISPR/CAS9 pode melhorar os índices de silenciamento. Nós também padronizamos uma série de metodologias simples e de baixo custo que podem ser utilizadas para avaliar funções efetoras de células NK como biogênese de grânulos citotóxicos, tráfico e reciclagem de receptores e produção de citocinas. 


\section{REFERÊNCIAS*}

1- COOPER, M.D., HERRIN, B.R. How did our complex immune system evolve?.Nat Rev Immunol., 10(1):2-3, doi: 10.1038/nri2686 (2010).

2- JANEWAY, C. A.; MEDZHITOV, R. Innate immune recognition. Annu. Rev. Immunol., 20, 197216, doi:10.1146/annurev.immunol.20.083001.084359 (2002).

3- $\quad$ BANCHEREAU, J.; STEINMAN, R. M. Dendritic cells and the control of immunity. Nature, 392, 245-252, doi:10.1038/32588 (1998).

4- $\quad$ IWASAKI, A.; MEDZHITOV, R. Regulation of adaptive immunity by the innate immune system. Science, 327, 291-295, doi:10.1126/science.1183021 (2010).

5- $\quad$ LITMAN, G. W., RAST, J. P.; FUGMANN, S. D. The origins of vertebrate adaptive immunity.Nat. Rev. Immunol., 10, 543-553, doi:10.1038/nri2807 (2010).

6- BOEHM, T.; SWANN, J. B. Origin and evolution of adaptive immunity. Annu. Rev. Anim Biosci., 2, 259-283, doi:10.1146/annurev-animal-022513-114201 (2014).

7- $\quad$ DENG, L., LUO, M., VELIKOVSKY, A.; MARIUZZA, R. A. Structural insights into the evolution of the adaptive immune system. Annu. Rev. Biophys., 42, 191-215, doi:10.1146/annurev-biophys083012-130422 (2013).

8- ELLMEIER, W., HAUST, L.; TSCHISMAROV, R. Transcriptional control of CD4 and CD8 coreceptor expression during $T$ cell development. Cell. Mol. Life, Sci 70, 4537-4553, doi:10.1007/s00018-013-1393-2 (2013).

9- $\quad$ SINCLAIR, C.; SEDDON, B. Overlapping and asymmetric functions of TCR signaling during thymic selection of CD4 and CD8 lineages. J. Immunol., 192, 5151-5159, doi:10.4049/jimmunol.1303085 (2014).

10- HERBERMAN, R. B., NUNN, M. E.; LAVRIN, D. H. Natural cytotoxic reactivity of mouse lymphoid cells against syngeneic acid allogeneic tumors. I. Distribution of reactivity and specificity. Int. J. Cancer, 16, 216-229 (1975).

11- KIESSLING, R., KLEIN, E.; WIGZELL, H. "Natural" killer cells in the mouse. I. Cytotoxic cells with specificity for mouse Moloney leukemia cells. Specificity and distribution according to genotype.Eur. J. Immunol., 5, 112-117, doi:10.1002/eji.1830050208 (1975).

12- VIVIER, E., TOMASELLO, E., BARATIN, M., WALZER, T.; UGOLINI, S. Functions of natural killer cells. Nat. Immunol., 9, 503-510, doi:10.1038/ni1582 (2008).

13- GRÉGOIRE, C. et al., The trafficking of natural killer cells. Immunol.Rev., 220, 169-182, doi:10.1111/j.1600-065X.2007.00563.x (2007).

14- ZHANG, Y. et al., In vivo kinetics of human natural killer cells: the effects of ageing and acute and chronic viral infection. Immunology, 121, 258-265, doi:10.1111/j.1365-2567.2007.02573.x (2007).

15 MOULY E CHEMIN K NGUYEN H CHOPIN M MESNARD L LEITE-DE-MORAES M BURLENDEFRANOUX O BANDEIRA A BORIES J. The Ets-1 transcription factor controls the development and function of natural regulatory T cells.J.Exp.Med., vol: 207 (10) pp: 2113-2125 (2010)

*De acordo com: ASSOCIAÇÃO BRASILEIRA DE NORMAS TÉCNICAS. NBR6023: informação e documentação: referências: elaboração. Rio de Janeiro, 2002. 
16. S. S. BOGGS, M. TREVISAN, K. PATRENE, K. GEOGOPOULOS. Lack of natural killer cell precursors in fetal liver of Ikaros knockout mutant mice. Nat. Immun., 16, 137-145 (1998).

17- BONAVIDA, B. NK cell phenotypic and functional heterogeneities and molecular mechanisms of cytotoxicity. Crit. Rev. Oncog., 19, 21-45 (2014).

18- $\quad$ ANFOSSI, N. et al., Human NK cell education by inhibitory receptors for MHC class I. Immunity 25, 331-342, doi:10.1016/J.Immuni., 2006.06.013 (2006).

19. M. LUETKE-EVERSLOH, M. KILLIG, C. ROMAGNANI. Signatures of human NK cell development and terminal differentiation. Front.Immunol., 4, 499 (2013).

20. M. T. ORR, L. L. LANIER.Natural killer cell education and tolerance.Cell, 142, 847-856 (2010).

21- MARSH, S. G. et al.,Killer-cell immunoglobulin-like receptor (KIR) nomenclature report, 2002. T. Ant., 62, 79-86 (2003).

22. F. ROMAGNÉ, E. VIVIER. Natural killer cell-based therapies. F. Med. Rep., 3, 9 (2011).

23- LANIER, L. L. Up on the tightrope: natural killer cell activation and inhibition. Nat. Immunol., 9, 495-502, doi:10.1038/ni1581 (2008).

24- LANIER, L. L. NK cell recognition. Annu. Rev. Immunol., 23, 225-274, doi:10.1146/annurev.immunol.23.021704.115526 (2005).

25. E. VIVIER et al., Innate or adaptive immunity? The example of natural killer cells.Science, 331, 44-49 (2011).

26- TOPHAM, N. J. ; HEWITT, E. W. Natural killer cell cytotoxicity: how do they pull the trigger? Immunology, 128, 7-15, doi:10.1111/j.1365-2567.2009.03123.x (2009).

27 J. A. TRAPANI. Granzymes, cytotoxic granules and cell death: the early work of Dr. Jurg Tschopp. Cell. Death Differ., 19, 21-27 (2012).

28 J. S. ORANGE.Formation and function of the lytic NK-cell immunological synapse.Nat. Rev. Immunol., 8, 713-725 (2008).

29 E. M. MACE et al., Cell biological steps and checkpoints in accessing NK cell cytotoxicity. Immunol.Cell.Biol., 92, 245-255 (2014).

30 BRYCESON, Y. T., MARCH, M. E., LJUNGGREN, H. G. ; LONG, E. O. Synergy among receptors on resting NK cells for the activation of natural cytotoxicity and cytokine secretion. Blood, 107, 159-166, doi:10.1182/blood-2005-04-1351 (2006).

31 A. CERWENKA, L. L. LANIER.Natural killer cell memory in infection, inflammation and cancer.Nat. Rev. Immunol., 16, 112-123 (2016).

32 J. G. O'LEARY, M. GOODARZI, D. L. DRAYTON, U. H. VON ANDRIAN.T cell- and B cellindependent adaptive immunity mediated by natural killer cells. Nat. Immunol., 7, 507-516 (2006).

33 R. K. REEVES et al., Antigen-specific NK cell memory in rhesus macaques. Nat. Immunol., 16, 927-932 (2015).

34 HAYAKAWA, Y. ; SMYTH, M. J. CD27 dissects mature NK cells into two subsets with distinct responsiveness and migratory capacity. J. Immunol., 176, 1517-1524 (2006). 
35 JACOBS, R. et al., CD56bright cells differ in their KIR repertoire and cytotoxic features from CD56dim NK cells. Eur. J. Immunol., 31, 3121-3127, doi:10.1002/15214141(2001010)31:10<3121::AID-IMMU3121>3.0.CO;2-4 (2001).

36- WAKIM, L. M. ; BEVAN, M. J. From the thymus to longevity in the periphery.Curr.Opin.Immunol., 22, 274-278, doi:10.1016/j.coi.2010.03.003 (2010).

37- XIONG, Y. ; BOSSELUT, R. CD4-CD8 differentiation in the thymus: connecting circuits and building memories. Curr.Opin.Immunol., 24, 139-145, doi:10.1016/j.coi.2012.02.002 (2012).

38- $\quad$ CRUZ-GUILLOTY, F. et al.,Runx3 and T-box proteins cooperate to establish the transcriptional program of effector CTLs. J. Exp. Med., 206, 51-59, doi:10.1084/jem.20081242 (2009).

39 CHIANG, S. C. et al.,Comparison of primary human cytotoxic T-cell and natural killer cell responses reveal similar molecular requirements for lytic granule exocytosis but differences in cytokine production. Blood, 121, 1345-1356, doi:10.1182/blood-2012-07-442558 (2013).

40 HOCHWELLER, K. et al., Dendritic cells control $T$ cell tonic signaling required for responsiveness to foreign antigen. Proc. Natl. Acad. Sci., U S A 107, 5931-5936, doi:10.1073/pnas.0911877107 (2010).

41 KOUP, R. A. et al.,Temporal association of cellular immune responses with the initial control of viremia in primary human immunodeficiency virus type 1 syndrome. J. Virol., 68, 4650-4655 (1994).

42 CALLAN, M. F. et al., Large clonal expansions of CD8+ T cells in acute infectious mononucleosis. Nat. Med., 2, 906-911 (1996).

43 WILLS, M. R. et al., The human cytotoxic T-lymphocyte (CTL) response to cytomegalovirus is dominated by structural protein pp65: frequency, specificity, and T-cell receptor usage of pp65specific CTL. J. Virol., 70, 7569-7579 (1996).

44 BUCHHOLZ, V. R., GRÄF, P. ; BUSCH, D. H. The origin of diversity: studying the evolution of multi-faceted CD8+ T cell responses. Cell. Mol. Life Sci., 69, 1585-1595, doi:10.1007/s00018-0120967-8 (2012).

45 TOMIYAMA, H., MATSUDA, T. ;Takiguchi, M. Differentiation of human CD8(+) T cells from a memory to memory/effector phenotype. J. Immunol., 168, 5538-5550 (2002).

46 OPFERMAN, J. T., OBER, B. T. ; ASHTON-RICKARDT, P. G. Linear differentiation of cytotoxic effectors into memory T lymphocytes. Science, 283, 1745-1748 (1999).

47- LAUVAU, G. et al., Priming of memory but not effector CD8 T cells by a killed bacterial vaccine. Science 294, 1735-1739, doi:10.1126/science,.1064571 (2001).

48 MUELLER, S. N., GEBHARDT, T., CARBONE, F. R. ; HEATH, W. R. Memory T cell subsets, migration patterns, and tissue residence. Annu. Rev. Immunol., 31, 137-161, doi:10.1146/annurevimmunol-032712-095954 (2013).

49 CURTSINGER, J. M., JOHNSON, C. M. ; MESCHER, M. F. CD8 T cell clonal expansion and development of effector function require prolonged exposure to antigen, costimulation, and signal 3 cytokine. J. Immunol., 171, 5165-5171 (2003). 
50 FERGUSON, A. R. ; ENGELHARD, V. H. CD8 T cells activated in distinct lymphoid organs differentially express adhesion proteins and coexpress multiple chemokine receptors. J. Immunol., 184, 4079-4086, doi:10.4049/jimmunol.0901903 (2010).

51 DUSTIN, M. L. ; LONG, E. O. Cytotoxic immunological synapses.Immunol.Rev., 235, 24-34, doi:10.1111/j.0105-2896.2010.00904.x (2010).

52 GRIFFITHS, G. M. Endocytosing the death sentence. J. Cell Biol., 160, 155-156, doi:10.1083/jcb.200212143 (2003).

53- SCHOENBERGER, S. P., TOES, R. E., VAN DER VOORT, E. I., OFFRINGA, R. ; MELIEF, C. J. T-CELL help for cytotoxic T lymphocytes is mediated by CD40-CD40L interactions. Nature, 393, 480-483, doi:10.1038/31002 (1998).

54 PALLISER, D., PLOEGH, H. ; BOES, M. Myeloid differentiation factor 88 is required for crosspriming in vivo. J. Immunol., 172, 3415-3421 (2004).

55 BUTZ, E. A. ; BEVAN, M. J. Massive expansion of antigen-specific CD8+ T cells during an acute virus infection. Immunity, 8, 167-175 (1998).

56 MURALI-KRISHNA, K. et al., Counting antigen-specific CD8 T cells: a reevaluation of bystander activation during viral infection. Immunity, 8, 177-187 (1998).

57 BLATTMAN, J. N. et al., Estimating the precursor frequency of naive antigen-specific CD8 T cells. J. Exp. Med., 195, 657-664 (2002).

58 HAMMARLUND, E. et al., Duration of antiviral immunity after smallpox vaccination. Nat. Med., 9, 1131-1137, doi:10.1038/nm917 (2003).

59 WILLIAMS, M.A., BEVAN, M.J. Effector and memory CTL differentiation. Annu.Rev. Immunol., 25, 171-92 (2007).

60 MUELLER, S. N., GEBHARDT, T., CARBONE, F. R. ; HEATH, W. R. Memory T cell subsets, migration patterns, and tissue residence. Annu. Rev. Immunol., 31, 137-161, doi:10.1146/annurevimmunol-032712-095954 (2013).

61 BETTS, M. R. et al.,HIV nonprogressors preferentially maintain highly functional HIV-specific CD8+ T cells. Blood 107, 4781-4789, doi:10.1182/blood,-2005-12-4818 (2006).

62 CLEMENTE, T., DOMINGUEZ, M. R., VIEIRA, N. J., RODRIGUES, M. M. ; AMARANTE-MENDES, G. P. In vivo assessment of specific cytotoxic T lymphocyte killing.Methods, 61, 105-109, doi:10.1016/j.ymeth.2013.02.007 (2013).

63 GERLACH, C. et al., Heterogeneous differentiation patterns of individual CD8+ T cells. Science 340, 635-639, doi:10.1126/science.,1235487 (2013).

64 ANDERSEN, M. H., SCHRAMA, D., THOR STRATEN, P. ; BECKER, J. C. Cytotoxic T cells. J. Invest.Dermatol. 126, 32-41, doi:10.1038/sj.jid.5700001 (2006).

65 DE SAINT BASILE, G., MÉNASCHÉ, G. ; FISCHER, A. Molecular mechanisms of biogenesis and exocytosis of cytotoxic granules. Nat. Rev. Immunol., 10, 568-579, doi:10.1038/nri2803 (2010).

66 GALANDRINI, R., CAPUANO, C. ; SANTONI, A. Activation of Lymphocyte Cytolytic Machinery: Where are We? Front.Immunol., 4, 390, doi:10.3389/fimmu.2013.00390 (2013). 
67 CHIANG, S. C. et al., Comparison of primary human cytotoxic T-cell and natural killer cell responses reveal similar molecular requirements for lytic granule exocytosis but differences in cytokine production. Blood, 121, 1345-1356.

68 VAN DER SLUIJS, P., ZIBOUCHE, M. ; VAN KERKHOF, P. Late steps in secretory lysosome exocytosis in cytotoxic lymphocytes. Front.Immunol., 4, 359, doi:10.3389/fimmu.2013.00359 (2013).

69 LETTAU, M., SCHMIDT, H., KABELITZ, D. ; JANSSEN, O. Secretory lysosomes and their cargo in T and NK cells. Immunol.Lett., 108, 10-19, doi:10.1016/j.imlet.2006.10.001 (2007).

70 LIEBERMAN, J. The ABCs of granule-mediated cytotoxicity: new weapons in the arsenal. Nat. Rev. Immunol., 3, 361-370, doi:10.1038/nri1083 (2003).

71 SHEN, D. T., MA, J. S., MATHER, J., VUKMANOVIC, S. ; RADOJA, S. Activation of primary T lymphocytes results in lysosome development and polarized granule exocytosis in CD4+ and CD8+ subsets, whereas expression of lytic molecules confers cytotoxicity to CD8+ T cells. J. Leukoc.Biol., 80, 827-837, doi:10.1189/jlb.0603298 (2006).

72 BENADO, A., NASAGI-ATIYA, Y. ; SAGI-EISENBERG, R. Protein trafficking in immune cells. Immunobiology 214, 403-421, doi:10.1016/j.imbio.,.2008.11.011 (2009).

73 ANGUS, K. L. ; GRIFFITHS, G. M. Cell polarisation and the immunological synapse. Curr.Opin.Cell.Biol., 25, 85-91, doi:10.1016/j.ceb.2012.08.013 (2013).

74 STINCHCOMBE, J. C., MAJOROVITS, E., BOSSI, G., FULLER, S. ; GRIFFITHS, G. M. Centrosome polarization delivers secretory granules to the immunological synapse. Nature, 443, 462-465, doi:10.1038/nature05071 (2006).

75 MENTLIK, A. N., SANBORN, K. B., HOLZBAUR, E. L. ; ORANGE, J. S. Rapid lytic granule convergence to the MTOC in natural killer cells is dependent on dynein but not cytolytic commitment. Mol. Biol. Cell., 21, 2241-2256, doi:10.1091/mbc.E09-11-0930 (2010).

76 J. C. STINCHCOMBE, E. MAJOROVITS, G. BOSSI, S. FULLER, G. M. GRIFFITHS.Centrosome polarization delivers secretory granules to the immunological synapse. Nature, 443, 462-465 (2006).

77 HOLT, O. J., GALLO, F. ; GRIFFITHS, G. M. Regulating secretory lysosomes. J. Biochem., 140, 712, doi:10.1093/jb/mvj126 (2006).

78 SANBORN, K. B. ; ORANGE, J. S. Navigating barriers: the challenge of directed secretion at the natural killer cell lytic immunological synapse. J. Clin.Immunol., 30, 358-363, doi:10.1007/s10875010-9372-y (2010).

79 SCHMIDT, H. et al.,Effector granules in human T lymphocytes: the luminal proteome of secretory lysosomes from human T cells. Cell.Commun.Signal., 9, 4, doi:10.1186/1478-811X-9-4 (2011).

80 BRIGHOUSE, A., DACKS, J. B. ; FIELD, M. C. Rab protein evolution and the history of the eukaryotic endomembrane system. Cell. Mol. Life Sci., 67, 3449-3465, doi:10.1007/s00018-0100436-1 (2010).

81 DACKS, J. B. ; FIELD, M. C. Evolution of the eukaryotic membrane-trafficking system: origin, tempo and mode. J. Cell.Sci., 120, 2977-2985, doi:10.1242/jcs.013250 (2007).

82 PEREIRA-LEAL, J. B. ; SEABRA, M. C. Evolution of the Rab family of small GTP-binding proteins. J. Mol. Biol., 313, 889-901, doi:10.1006/jmbi.2001.5072 (2001). 
83 ECHARD, A. et al., Alternative splicing of the human Rab6A gene generates two close but functionally different isoforms. Mol. Biol. Cell., 11, 3819-3833 (2000).

84 JÉKELY, G. Small GTPases and the evolution of the eukaryotic cell. Bioessays, 25, 1129-1138, doi:10.1002/bies.10353 (2003).

85 SALMINEN, A. ; NOVICK, P. J. A ras-like protein is required for a post-Golgi event in yeast secretion. Cell, 49, 527-538 (1987).

86 SEGEV, N., MULHOLLAND, J. ; BOTSTEIN, D. The yeast GTP-binding YPT1 protein and a mammalian counterpart are associated with the secretion machinery. Cell, 52, 915-924 (1988).

87 TOUCHOT, N., CHARDIN, P. ; TAVITIAN, A. Four additional members of the ras gene superfamily isolated by an oligonucleotide strategy: molecular cloning of YPT-related cDNAs from a rat brain library. Proc. Natl. Acad. Sci., U S A 84, 8210-8214 (1987).

88 ZAHRAOUI, A., TOUCHOT, N., CHARDIN, P. ; TAVITIAN, A. Complete coding sequences of the ras related rab 3 and 4 cDNAs. Nucleic.Acids. Res., 16, 1204 (1988).

89 GURKAN, C. et al., Large-scale profiling of Rab GTPase trafficking networks: the membrome. Mol. Biol. Cell., 16, 3847-3864, doi:10.1091/mbc.E05-01-0062 (2005).

90 ITZEN, A. ; GOODY, R. S. GTPases involved in vesicular trafficking: structures and mechanisms. Semin.Cell. Dev. Biol., 22, 48-56, doi:10.1016/j.semcdb.2010.10.003 (2011).

91 KELLY, E. E., HORGAN, C. P., GOUD, B. ; MCCAFFREY, M. W. The Rab family of proteins: 25 years on. Biochem. Soc. Trans., 40, 1337-1347, doi:10.1042/BST20120203 (2012).

92 CHAVRIER, P. et al., Hypervariable C-terminal domain of rab proteins acts as a targeting signal. Nature, 353, 769-772, doi:10.1038/353769a0 (1991).

93 STENMARK, H. Rab GTPases as coordinators of vesicle traffic. Nat. Rev. Mol. Cell. Biol., 10, 513-525, doi:10.1038/nrm2728 (2009).

94 PFEFFER, S.R. Rab GTPase regulation of membrane identity. Curr.Opin.Cell. Biol.,. 25, 414-9, 10.1016/j.ceb.2013.04.002 (2013)

95 STENMARK, H. ; OLKKONEN, V. M. The Rab GTPase family.Gen. Biol., 2, REVIEWS3007 (2001).

96 CASEY, T. M., MEADE, J. L. ; HEWITT, E. W. Organelle proteomics: identification of the exocytic machinery associated with the natural killer cell secretory lysosome. Mol. Cell.Proteomics., 6, 767-780, doi:10.1074/mcp.M600365-MCP200 (2007).

97 CHAVRIER, P., PARTON, R. G., HAURI, H. P., SIMONS, K. \& ZERIAL, M. Localization of low molecular weight GTP binding proteins to exocytic and endocytic compartments. Cell, 62, 317-329 (1990).

98 TISDALE, E. J. A Rab2 mutant with impaired GTPase activity stimulates vesicle formation from pre-Golgi intermediates. Mol. Biol. Cell., 10, 1837-1849 (1999).

99 MITRA, S., CHENG, K. W. ; MILLS, G. B. Rab GTPases implicated in inherited and acquired disorders. Semin.Cell. Dev. Biol., 22, 57-68, doi:10.1016/j.semcdb.2010.12.005 (2011).

100 CULINE, S. et al., A small GTP-binding protein is frequently overexpressed in peripheral blood mononuclear cells from patients with solid tumours. Eur. J. Cancer, 30A, 670-674 (1994). 
101 LOMNYTSKA, M. I. et al., Diagnostic protein marker patterns in squamous cervical cancer. Proteomics Clin.Appl., 4, 17-31, doi:10.1002/prca.200900086 (2010).

102 BARBIERI, M. A. et al., Epidermal growth factor and membrane trafficking. EGF receptor activation of endocytosis requires Rab5a. J. Cell Biol., 151, 539-550 (2000).

103 CROIZET-BERGER, K., DAUMERIE, C., COUVREUR, M., COURTOY, P. J. ; VAN DEN HOVE, M. F. The endocytic catalysts, Rab5a and Rab7, are tandem regulators of thyroid hormone production. Proc. Natl. Acad. Sci., U S A 99, 8277-8282, doi:10.1073/pnas.122187699 (2002).

104 SCHMIDLIN, F. et al.,Dynamin and Rab5a-dependent trafficking and signaling of the neurokinin 1 receptor. J. Biol. Chem., 276, 25427-25437, doi:10.1074/jbc.M101688200 (2001).

105 YANG, P. S. et al.,Rab5A is associated with axillary lymph node metastasis in breast cancer patients. Cancer Sci., 102, 2172-2178, doi:10.1111/j.1349-7006.2011.02089.x (2011).

106 ALVAREZ-DOMINGUEZ, C. ; STAHL, P. D. Increased expression of Rab5a correlates directly with accelerated maturation of Listeria monocytogenes phagosomes. J. Biol. Chem., 274, 1145911462 (1999).

107 ZEIGERER, A. et al., Rab5 is necessary for the biogenesis of the endolysosomal system in vivo. Nature, 485, 465-470, doi:10.1038/nature11133 (2012).

108 HUNZIKER, W. ; PETERS, P. J. Rab17 localizes to recycling endosomes and regulates receptormediated transcytosis in epithelial cells. J. Biol. Chem., 273, 15734-15741 (1998).

109 ZACCHI, P. et al., Rab17 regulates membrane trafficking through apical recycling endosomes in polarized epithelial cells. J. Cell.Biol., 140, 1039-1053 (1998).

110 BEAUMONT, K.A., HAMILTON N.A., MOORES M.T., BROWN D.L., OHBAYASHI N., CAIRNCROSS O., COOK A.L., SMITH A.G., MISAKI R., FUKUDA M., TAGUCHI T., STURM R.A., STOW J.L. the recycling endosome protein Rab17 regulates melanocytic filopodia formation and melanosome trafficking. Traffic, 12, 627-43.doi: 10.1111/j.1600-0854.2011.01172.x. (2011)

111 GERONDOPOULOS, A. et al., Rab18 and a Rab18 GEF complex are required for normal ER structure. J. Cell.Biol., 205, 707-720, doi:10.1083/jcb.201403026 (2014).

112 BEM, D. et al., Loss-of-function mutations in RAB18 cause Warburg micro syndrome. Am. J. Hum.Genet., 88, 499-507, doi:10.1016/j.ajhg.2011.03.012 (2011).

113 WESTBROEK, W. et al.,Cellular defects in Chediak-Higashi syndrome correlate with the molecular genotype and clinical phenotype. J. Invest.Dermatol., 127, 2674-2677, doi:10.1038/sj.jid.5700899 (2007).

114 HUIZING, M., HELIP-WOOLEY, A., WESTBROEK, W., GUNAY-AYGUN, M. ; GAHL, W. A. Disorders of lysosome-related organelle biogenesis: clinical and molecular genetics. Annu. Rev. Genomics Hum.Genet., 9, 359-386, doi:10.1146/annurev.genom.9.081307.164303 (2008).

115 WEI, M. L. Hermansky-Pudlak syndrome: a disease of protein trafficking and organelle function. Pigment Cell Res., 19, 19-42, doi:10.1111/j.1600-0749.2005.00289.x (2006).

116 FISCHER, A., LATOUR, S. ; DE SAINT BASILE, G. Genetic defects affecting lymphocyte cytotoxicity. Curr.Opin.Immunol., 19, 348-353, doi:10.1016/j.coi.2007.04.006 (2007).

117 MÉNASCHÉ, G. et al., Mutations in RAB27A cause Griscelli syndrome associated with haemophagocytic syndrome. Nat. Genet., 25, 173-176, doi:10.1038/76024 (2000). 
118 MÉNASCHÉ, G. et al., Griscelli syndrome restricted to hypopigmentation results from a melanophilin defect (GS3) or a MYO5A F-exon deletion (GS1). J. Clin.Invest., 112, 450-456, doi:10.1172/JCl18264 (2003).

119 MITRA, S., CHENG, K. W. ; MILLS, G. B. Rab GTPases implicated in inherited and acquired disorders. Semin.Cell. Dev. Biol., 22, 57-68, doi:10.1016/j.semcdb.2010.12.005 (2011).

120 CHENG, K. W., LAHAD, J. P., GRAY, J. W. ; MILLS, G. B. Emerging role of RAB GTPases in cancer and human disease. Cancer Res., 65, 2516-2519, doi:10.1158/0008-5472.CAN-05-0573 (2005).

121 SUBRAMANI, D. ; ALAHARI, S. K. Integrin-mediated function of Rab GTPases in cancer progression. Mol. Cancer, 9, 312, doi:10.1186/1476-4598-9-312 (2010).

122 TRAMBAS, C. M. ; GRIFFITHS, G. M. Delivering the kiss of death. Nat. Immunol., 4, 399-403, doi:10.1038/ni0503-399 (2003).

123 SARRAF, C. E. Immunolabeling for electron microscopy. Methods Mol. Med., 40, 439-452, doi:10.1385/1-59259-076-4:439 (2000).

124 A. M. ROJAS, G. FUENTES, A. RAUSELL, A. VALENCIA. The Ras protein superfamily: evolutionary tree and role of conserved amino acids. J. Cell.Biol., 196, 189-201 (2012).

125 E. J. TISDALE, J. R. BOURNE, R. KHOSRAVI-FAR, C. J. DER, W. E. Balch. GTP-binding mutants of rab1 and rab2 are potent inhibitors of vesicular transport from the endoplasmic reticulum to the Golgi complex. J. Cell Biol., 119, 749-761 (1992).

126 C. LI ET AL., Synaptic targeting of rabphilin-3A, a synaptic vesicle Ca2+/phospholipid-binding protein, depends on rab3A/3C. Neuron, 13, 885-898 (1994).

127 G. BALDINI, T. HOHL, H. Y. LIN, H. F. LODISH. Cloning of a Rab3 isotype predominantly expressed in adipocytes. Proc. Natl. Acad. Sci., 89, 5049-5052 (1992).

128 C. BUCCI ET al., Co-operative regulation of endocytosis by three Rab5 isoforms. FEBS Lett., 366, 65-71 (1995).

129 A. ZAHRAOUI, N. TOUCHOT, P. CHARDIN, A. TAVITIAN. The human Rab genes encode a family of GTP-binding proteins related to yeast YPT1 and SEC4 products involved in secretion. J. Biol. Chem., 264, 12394-12401 (1989).

130 P. CHAVRIER, R. G. PARTON, H. P. HAURI, K. SIMONS, M. ZERIAL.Localization of low molecular weight GTP binding proteins to exocytic and endocytic compartments.Cell, 62, 317-329 (1990).

131 E. J. TISDALE, W. E. BALCH. Rab2 is essential for the maturation of pre-Golgi intermediates. J. Biol. Chem., 271, 29372-29379 (1996).

132 M. AIZAWA, M. FUKUDA. Small GTPase Rab2B and Its Specific Binding Protein Golgiassociated Rab2B Interactor-like 4 (GARI-L4) Regulate Golgi Morphology. J. Biol. Chem., 290, 2225022261 (2015).

133 E. J. TISDALE, F. AZIZI, C. R. ARTALEJO.Rab2 utilizes glyceraldehyde-3-phosphate dehydrogenase and protein kinase $C\{i o t a\}$ to associate with microtubules and to recruit dynein. J. Biol. Chem., 284, 5876-5884 (2009).

$134 \mathrm{X}$. NI et al., Molecular cloning and characterization of a novel human Rab ( Rab2B) gene. J. Hum.Genet., 47, 548-551 (2002). 
135 R. D. BAGSHAW, D. J. MAHURAN, J. W. CALLAHAN. A proteomic analysis of lysosomal integral membrane proteins reveals the diverse composition of the organelle. Mol. Cell.Proteomics, 4, 133143 (2005).

136 B. SCHRÖDER et al. Integral and associated lysosomal membrane proteins. Traffic, 8, 16761686 (2007).

137 GÖRG, A., WEISS, W. ; DUNN, M. J. Current two-dimensional electrophoresis technology for proteomics. Proteomics, 4, 3665-3685, doi:10.1002/pmic.200401031 (2004).

138 ARNTZEN, M., BULL, V. H. ; THIEDE, B. Cell death proteomics database: consolidating proteomics data on cell death. J. Proteome Res., 12, 2206-2213, doi:10.1021/pr4000703 (2013).

139 HWANG, S. I. et al.,Systematic characterization of nuclear proteome during apoptosis: a quantitative proteomic study by differential extraction and stable isotope labeling. Mol. Cell.Proteomics, 5, 1131-1145, doi:10.1074/mcp.M500162-MCP200 (2006).

140 SCHMIDT, H. et al., 2-D DIGE analyses of enriched secretory lysosomes reveal heterogeneous profiles of functionally relevant proteins in leukemic and activated human NK cells. Proteomics, 8 , 2911-2925, doi:10.1002/pmic.200800170 (2008).

141 SCHMIDT, H. et al., Effector granules in human T lymphocytes: the luminal proteome of secretory lysosomes from human T cells. Cell.Commun. Signal, 9, 4, doi:10.1186/1478-811X-9-4 (2011).

142 FOSTER, L. J. et al., A mammalian organelle map by protein correlation profiling. Cell, 125, 187-199, doi:10.1016/j.cell.2006.03.022 (2006).

143 MOOTHA, V. K. et al., Integrated analysis of protein composition, tissue diversity, and gene regulation in mouse mitochondria. Cell, 115, 629-640 (2003).

144 BELL, A. W. et al., Proteomics characterization of abundant Golgi membrane proteins. J. Biol. Chem., 276, 5152-5165, doi:10.1074/jbc.M006143200 (2001).

145 BREUZA, L. et al., Proteomics of endoplasmic reticulum-Golgi intermediate compartment (ERGIC) membranes from brefeldin A-treated HepG2 cells identifies ERGIC-32, a new cycling protein that interacts with human Erv46. J. Biol. Chem., 279, 47242-47253, doi:10.1074/jbc.M406644200 (2004).

146 BARBE, L. et al.,Toward a confocal subcellular atlas of the human proteome. Mol. Cell.Proteomics, 7, 499-508, doi:10.1074/mcp.M700325-MCP200 (2008).

147 SARRAF, C. E. Immunolabeling for electron microscopy. Methods Mol. Med., 40, 439-452, doi:10.1385/1-59259-076-4:439 (2000).

$148 \mathrm{YU}$, L. et al.,Termination of autophagy and reformation of lysosomes regulated by mTOR. Nature, 465, 942-946, doi:10.1038/nature09076 (2010).

149 KREUZALER, P. A. et al., Stat3 controls lysosomal-mediated cell death in vivo. Nat. Cell. Biol., 13, 303-309, doi:10.1038/ncb2171 (2011).

150 TAKAMORI, S. et al., Molecular anatomy of a trafficking organelle. Cell, 127, 831-846, doi:10.1016/j.cell.2006.10.030 (2006). 
151 MARGUS, H., PADARI, K. ; POOGA, M. Insights into cell entry and intracellular trafficking of peptide and protein drugs provided by electron microscopy. Adv. Drug.Deliv.Rev., 65, 1031-1038, doi:10.1016/j.addr.2013.04.013 (2013).

152 FIRE, A. et al., Potent and specific genetic interference by double-stranded RNA in Caenorhabditis elegans. Nature, 391, 806-811, doi:10.1038/35888 (1998).

153 SHAN, G. RNA interference as a gene knockdown technique. Int. J. Biochem. Cell Biol., 42, 1243-1251, doi:10.1016/j.biocel.2009.04.023 (2010).

154 HANNON GJ. RNA interference.Nature 418, 244-51 (2002).

155 KURRECK, J. RNA interference: from basic research to therapeutic applications. Angew Chem. Int. 48, 1378-1398, doi:10.1002/anie.200802092 (2009).

156 STEWART, S. A. et al.,Lentivirus-delivered stable gene silencing by RNAi in primary cells. RNA 9, 493-501 (2003).

157 SLIVA, K. ; SCHNIERLE, B. S. Selective gene silencing by viral delivery of short hairpin RNA. Virol J. 7, 248, doi:10.1186/1743-422X-7-248 (2010).

158 L. CONG et al., Multiplex genome engineering using CRISPR/Cas systems. Science, 339, 819823 (2013).

159 M. JINEK et al., A programmable dual-RNA-guided DNA endonuclease in adaptive bacterial immunity. Science, 337, 816-821 (2012).

160 SU SU, DAWN M BETTERS, MUTHALAGU R, KEYVAN K, ALEAH S, XINGMIN F, ELISSA F, MATTIAS C, ANDREAS L, RICHARD C., Optimizing Lentiviral Transduction of Human Natural Killer Cells. Blood, 118:4714 (2011).

161 M. CARLSTEN, R. W. CHILDS. Genetic Manipulation of NK Cells for Cancer Immunotherapy: Techniques and Clinical Implications. Front.Immunol., 6, 266 (2015).

162 F. MICUCCl et al., High-efficient lentiviral vector-mediated gene transfer into primary human NK cells. Exp. Hematol., 34, 1344-1352 (2006).

163 T. SUTLU et al., Inhibition of intracellular antiviral defense mechanisms augments lentiviral transduction of human natural killer cells: implications for gene therapy. Hum.Gene Ther., 23, 10901100 (2012).

164 STINCHCOMBE, J. C., BOSSI, G., BOOTH, S. ; GRIFFITHS, G. M. The immunological synapse of CTL contains a secretory domain and membrane bridges. Immunity, 15, 751-761 (2001).

165 BUCCI, C., BAKKE, O. ; PROGIDA, C. Rab7b and receptors trafficking. Commun.Integr.Biol., 3, 401-404, doi:10.4161/cib.3.5.12341 (2010).

166 FAN, G. H., LAPIERRE, L. A., GOLDENRING, J. R. ; RICHMOND, A. Differential regulation of CXCR2 trafficking by Rab GTPases. Blood 101, 2115-2124, doi:10.1182/blood,-2002-07-1965 (2003).

167 PELLINEN, T. et al., Integrin trafficking regulated by Rab21 is necessary for cytokinesis. Dev. Cell, 15, 371-385, doi:10.1016/j.devcel.2008.08.001 (2008). 


\section{APÊNDICES}

APÊNDICE A - Lista das proteínas mais abundantes identificadas nos preparados das amostras dos grânulos das CTLs em 1D-SDS-PAGE.

\begin{tabular}{|c|c|c|c|c|}
\hline Protein ID & $\begin{array}{c}\text { Accession } \\
n^{\circ}\end{array}$ & $M W / p I$ & Coverage & $\begin{array}{l}\text { Matched } \\
\text { peptides }\end{array}$ \\
\hline Heat shock protein HSP90-beto (TSTA) & P11499 & $83,326 / 50$ & $42 \%$ & 24 \\
\hline NEDD1 protein & P33215 & $72.970 / 8.3$ & $23 \%$ & 11 \\
\hline BIP/GRP78 & $p 20029$ & $72,423 / 5.1$ & $59 \%$ & 38 \\
\hline Heat-shock cognate $71 \mathrm{kD}$ a protein & P08109 & $70,872 / 5.4$ & $50 \%$ & 36 \\
\hline Perforin & $P 10820$ & $62.082 / 8.4$ & $39 \%$ & 25 \\
\hline T-eomplex protein $1 / T C P$-1 thete/CCT-thete & P42932 & $59.556 / 5.4$ & $37 \%$ & 17 \\
\hline Zine finger protein $94\left(Z f_{p}-94\right)$ & Q9Z:109 & $59,156 / 7.8$ & $35 \%$ & 18 \\
\hline Pyruvete kinose, $M 2$ isoryme & P52480 & $57.888 / 7.2$ & 505. & 31 \\
\hline protein disulfide isomerose A3 presursor (ERp60) & $P 27773$ & $56.622 / 60$ & $46 \%$ & 23 \\
\hline Alphe enelese/Enolase-1 & P17:82 & $47,141 / 6.4$ & 55\% & 27 \\
\hline DNAse gammo/DHP2/LS-DNAse/DNAse I-like 3 & 055070 & $35,760 / 8.9$ & $40 \%$ & 14 \\
\hline Purine nueleoside phosphorylase/tnosine phosphorylose & $P 23492$ & $32,277 / 5.8$ & $54 \%$ & 18 \\
\hline Gronzyme A presursor/TSP-1/CTLA-3 & P11032 & $28,599 / 9.5$ & $61 \%$ & 19 \\
\hline Phosphomannomutose 2 (PMM 2) & Q9Z2M7 & $27,657 / 6.0$ & $61 \%$ & 15 \\
\hline Gronzyme F preeursor/MCSP-3/CCP4 4 & Posses & $27.643 / 9.9$ & $40 \%$ & 11 \\
\hline Gronayme E preeursor/CCP3 & POses 4 & $27.494 / 9.7$ & $49 \%$ & 13 \\
\hline Grenzyme $B / C T L A-1 / C C P 1$ & P04187 & $27.470 / 9.8$ & $30 \%$ & 15 \\
\hline Gronzyme $G$ precursor/MCSP-1 & P13366 & $27,381 / 9.6$ & $61 \%$ & 13 \\
\hline Gronzyme $C / C C P 2$ & POss82 & $27,311 / 9.3$ & $62 \%$ & 17 \\
\hline Ubiquitin cerbexyl-terminal hydrolose isozyme L1 (UCH-L1) & Q9R0P9 & $24,838 / 5.1$ & $40 \%$ & 10 \\
\hline Ras-related Rob-17 & P35292 & $23.640 / 5.4$ & $39 \%$ & 7 \\
\hline Ros-related protein Reb-2A & PS 3994 & $23.548 / 6.1$ & $57 \%$ & 9 \\
\hline PPIose precursor/Rotamose/Cyclophilin B & P24369 & $22,713 / 9.5$ & $56 \%$ & 15 \\
\hline Peroxiredoxin 1 (thioredoxin peroxidase 2) & P35700 & $22.177 / 8.3$ & $41 \%$ & 9 \\
\hline 605 ribosomal protein L9 & P51410 & $21.882 / 10$ & 58\% & 12 \\
\hline Ferritin light chein 1 & P29391 & $20,803 / 5.7$ & $46 \%$ & 7 \\
\hline Adenine phosphoribosyltronsferose/APRT & P08030 & $19.763 / 6.3$ & $58 \%$ & 9 \\
\hline Translationally eontrelled tumer protein (TCTP) & P14701 & $19.462 / 4.8$ & $42 \%$ & 12 \\
\hline 40 S ribosomal protein $\$ 10$ & po9900 & $18,916 / 10.2$ & $70 \%$ & 14 \\
\hline Cofilin & $P 18760$ & $18,560 / 8.2$ & 69\% & 12 \\
\hline PPIose/Rotamose/Cyclophilin A & P17742 & $17.972 / 7.7$ & 455 & 12 \\
\hline $40 S$ ribosomal protein $\$ 16$ & P14131 & $\begin{array}{c}16,356 / 10 \\
2\end{array}$ & $68 \%$ & n \\
\hline Superoxide dismutose [Cu-Zn] & P08228 & $15,943 / 6.0$ & $54 \%$ & 9 \\
\hline Myosin light chain alkali (MLC3nm) & Q60605 & $15.731 / 4.8$ & $62 \%$ & 8 \\
\hline Cystatin $C$ & $P 21460$ & $15.531 / 9.2$ & $53 \%$ & 6 \\
\hline Profilin : & P10924 & $14,957 / 8.5$ & $46 \%$ & 8 \\
\hline Galectin-1 & P10812 & $14,866 / 5.3$ & $62 \%$ & 10 \\
\hline Histene H2A & P22752 & $14,182 / 10.9$ & 635 & 7 \\
\hline Histene H2B & P10854 & $\begin{array}{c}13,936 / 10 \\
3\end{array}$ & $65 \%$ & 18 \\
\hline
\end{tabular}

Tabela 3 - Lista das proteínas mais abundantes identificadas nos preparados das amostras dos grânulos das CTLs em 1DSDS-PAGE. A maioria das bandas visualizadas no 1D SDS-PAGE marcadas com Coomassie Blue foram cortadas do gel e submetidas a digestão por tripsina no gel e análise MS/MS. Devido a complexidade das amostras, como cada banda provavelmente contém muitas proteínas diferentes, somente proteínas com alta pontuação no MS-Fit, cobertura dos peptídeos acima de $35 \%$ e um número significante de pareamento de peptídios foram selecionados nessa primeira pesquisa. Trinta e nove proteínas foram, portanto, nomeadas como as proteínas mais abundantes em nossa fração de grânulos das CTLs, incluindo as esperadas perforina e as granzimas A, B, C, E, F e G. (Amarante-Mendes Et. al, dados não publicados). 


\section{APÊNDICES}

APÊNDICE B - Proteínas identificadas nos grânulos das CTLs em 1D-SDS-PAGE.

\begin{tabular}{|c|c|c|c|c|c|}
\hline Spot & Protein ID & $\begin{array}{c}\text { Accession } \\
n^{\rho}\end{array}$ & $M W / p I$ & Coverage & $\begin{array}{l}\text { Matched } \\
\text { peptides }\end{array}$ \\
\hline 1 & $\beta$-spectrin/fodrin & Q62261 & $274425 / 5.7$ & $27 \%$ & 65 \\
\hline 2 & *BIP/GRP78 & P20029 & $72423 / 5.1$ & $54 \%$ & 26 \\
\hline 3 & *Heat-shock cognate 71kDa protein & P08109 & $70872 / 5.4$ & $36 \%$ & 20 \\
\hline 4 & $75 \mathrm{kDa}$ glucose regulated protein (GRP 75)/Mortalin & P38647 & $73529 / 5.9$ & $19 \%$ & 8 \\
\hline 5 & Vimentin & P20152 & $53688 / 5.1$ & $21 \%$ & 12 \\
\hline 6 & Calreticulin/calregulin/ERP60 & NP_031617 & $48136 / 4.33$ & $53 \%$ & 24 \\
\hline 7 & Calreticulin/calregulin/ERP60 & NP_031617 & $48136 / 4.33$ & $54 \%$ & 23 \\
\hline 8 & *Disulfide isomerase ER-60 & P27773 & $56622 / 6.0$ & $42 \%$ & 20 \\
\hline 9 & Angiopoietin-related protein 2 precursor & Q9R045 & $57119 / 7.3$ & $20 \%$ & 7 \\
\hline 10 & *Alpha enolase/Enolase-1 & P17182 & $47453 / 6.4$ & $76 \%$ & 34 \\
\hline 11 & *Alpha enolase/Enolase-1 & P17182 & $47453 / 6.4$ & $45 \%$ & 18 \\
\hline 12 & Cathepsin D precursor & P18242 & $44954 / 6.7$ & $34 \%$ & 13 \\
\hline 13 & Cathepsin D precursor & P18242 & $44954 / 6.7$ & $34 \%$ & 12 \\
\hline 14 & $\beta$-actin & NP_001092 & $42052 / 5.29$ & $42 \%$ & 12 \\
\hline 15 & Aldose reductase & P45376 & $35733 / 6.7$ & $24 \%$ & 7 \\
\hline 16 & NUDIX & NP_705789 & $35623 / 9.15$ & $38 \%$ & 13 \\
\hline 17 & *Granzyme E & P08884 & $27494 / 9.7$ & $26 \%$ & 5 \\
\hline 18 & *Granzyme $A / C T L A-3 / T S P-1$ & P11032 & $28599 / 9.5$ & $41 \%$ & 9 \\
\hline 19 & *Granzyme $A / C T L A-3 / T S P-1$ & P11032 & $28599 / 9.5$ & $57 \%$ & 17 \\
\hline 20 & ${ }^{*}$ Granzyme A/CTLA-3/TSP-1 & P11032 & $28599 / 9.5$ & $46 \%$ & 10 \\
\hline 21 & Chloride intracellular channel protein 1/NCC27/p64 CLCP & Q9Z1Q5 & $27013 / 5.1$ & $44 \%$ & 9 \\
\hline 22 & Chloride intracellular channel protein $1 /$ NCC27/p64 CLCP & Q9Z1Q5 & $27013 / 5.1$ & $39 \%$ & 9 \\
\hline 23 & Proteasome subunit alpha type $1 /$ Macropain subunit $C 2$ & Q9R1P4 & $29547 / 6.0$ & $34 \%$ & 9 \\
\hline 24 & Ubiquitin carboxyl-terminal hydrolase isozyme L3 (UCH-L3) & Q9JKB1 & $26152 / 5.0$ & $43 \%$ & 7 \\
\hline 25 & Phosphoglycerate mutase $1 /$ PGAM-B & Q9DBJ1 & $28832 / 6.7$ & $59 \%$ & 13 \\
\hline 26 & *Granzyme C/CCP2 & P08882 & $27311 / 9.3$ & $75 \%$ & 25 \\
\hline 27 & Triosephosphate isomerase/TIM & P17751 & $26713 / 6.9$ & $48 \%$ & 13 \\
\hline 28 & Triosephosphate isomerase/TIM & P17751 & $26713 / 6.9$ & $40 \%$ & 9 \\
\hline 29 & *Translationally controlled tumor protein (TCTP) & P14701 & $19462 / 4.8$ & $37 \%$ & 8 \\
\hline 30 & *Translationally controlled tumor protein (TCTP) & P14701 & $19462 / 4.8$ & $44 \%$ & 12 \\
\hline 31 & *Adenine phosphoribosyltransferase/APRT & P08030 & $19763 / 6.3$ & $58 \%$ & 8 \\
\hline 32 & ${ }^{*}$ Granzyme B/CTLA-1/CCP1 & P04187 & $27470 / 9.8$ & $30 \%$ & 7 \\
\hline 33 & MAPK $9 / J N K 2$ & Q9WTU6 & $48190 / 5.6$ & $21 \%$ & 9 \\
\hline 34 & Nucleoside diphosphate kinase B (NDK B)/ NM23-M2 & Q01768 & $17363 / 7.0$ & $68 \%$ & 9 \\
\hline 35 & Partitioning defective- 6 homolog gamma/PARGA & Q9JK84 & $42341 / 7.4$ & $14 \%$ & 4 \\
\hline \multirow[t]{9}{*}{36} & PCNA/cyclin? & P17918 & $28785 / 4.7$ & $16 \%$ & 5 \\
\hline & phosphatidylethanolamine-binding protein (PEBP) & P70296 & $20831 / 5.2$ & $55 \%$ & 7 \\
\hline & *PPIase/Rotamase/Cyclophilin A & P17742 & $17972 / 7.7$ & $50 \%$ & 9 \\
\hline & *Pyruvate kinase, M2 isozyme & P52480 & $57888 / 7.2$ & $17 \%$ & 8 \\
\hline & Ras-related protein Rab-18?? & P35293 & $23035 / 5.2$ & $34 \%$ & 6 \\
\hline & Ras-related protein Rab-5A?? & Q9CQD1 & $23599 / 8.3$ & $32 \%$ & 6 \\
\hline & Serine protease inhibitor $A 3 K /$ Serpin $A 3 K /$ Contrapsin & P07759 & $46880 / 5.1$ & $14 \%$ & 4 \\
\hline & *Superoxide dismutase $[\mathrm{Cu}-\mathrm{Zn}]$ & P08228 & $15943 / 6.0$ & $57 \%$ & 10 \\
\hline & Trangelin 2 & Q9WVA4 & $23597 / 6.6$ & $34 \%$ & 7 \\
\hline
\end{tabular}

Tabela 4-Lista das proteínas identificadas por eletroforese 2D. Para maximizar a identificação das proteínas presentes em nossa fração de grânulo, nós separamos as amostras por 2D-SDS-PAGE, usando diferentes gradientes de pl. Considerando que a maioria das granzimas são básicas e se incluem entre os constituintes mais abundantes dos grânulos secretórios, não foi uma surpresa descobrir que uma grande quantidade das proteínas não foram separadas por focalização isoelétrica em gradientes de pl 3-6 e pl 5-8. De fato, uma forte marcação foi sempre detectada em uma borda muito básica nos géis com os pl de 3-6 e 5-8 (dados não mostrados). Embora tenha sido corrido muitos géis 2D-SDS-PAGE com pl 7-10, nenhum trouxe uma boa resolução das proteínas básicas dos grânulos citotóxicos. Então, nós não fomos capazes de isolar bandas únicas das proteínas básicas. Contudo, por amostragem consistente na borda de base de ambos os géis de PI 3-6 e 5-8, nós identificamos com sucesso as granzimas, tão bem quanto às outras proteínas tais como ciclofilinas A e B e NUDIX. (Amarante-Mendes Et. al, dados não publicados). 